المدضص

هدف الدراسة :- التعرف على المضامين التربوية الاجتماعية المستتبطة من كتاب الآداب الثرعية والمنح المرعية لابن مفلح المقدي ، وتطبيقاتها التربوية في مجال حياة الناس اليومية .

\title{
منهج الدراسة
}

اعتمدت الباحثة على المنهج الوصفي الاستتباطي ، حيث يتم استخراج المضامين التربوية الاجتماعية من خلا نصوص كتاب الآداب الثرعية ، ثم إدراجها

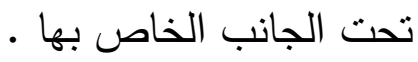
أهم النتائج

تضمنت نصوص كتاب الآداب الثرعية لابن مفلح المقدي عدد من المضامين التربوية الاجتماعية التي لا غنى عنها في حياة كل مسلم ، حيث اهتمت بجميع جوانب حياة الإنسان الاجتماعية ومن أهمها :- الاعيه المضامين التربوية الاجتماعية المتعلقة بعلاقة الفرد المسلم بوالديه كبر الوالدين وطاعتهما والاستغفار لهما واستثذانهما في طلب العلم وصلة رحمهما . المضامين التربوية الاجتماعية المتعلقة بعلاقة الفرد المسلم بسائر المسلمين كموالاة المسلمين والنصح لهم وارشادهم وشكرهم عند صناعة المعروف وحسن • جوارهم وآداب صحبتهم وزيارتهم المضامين التربوية الاجتماعية المتعلقة بعلاقة الفرد المسلم بأقاربه ممثلة في

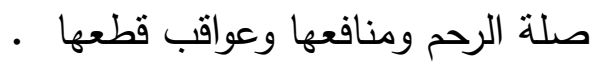
المضامين التربوية الاجتماعية المتعلقة بحقوق الإنسان كحق الانسان في التكريم والتعليم والتملك وحق الطريق والعدل والمواساة بين الناس 


\section{المضامين التريوية الاجتماعية لصلاح الأمة المستتبطة د. رجاء بنت سبد علي}

المضامين التربوية الاجتماعية المتعلقة بالآفات المهددة للمجتمع كآفة الزنا والربا

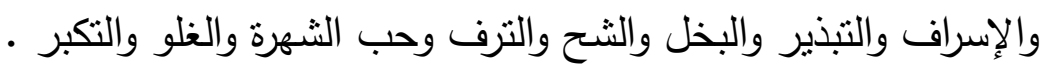

المضامين التربوية الاجتماعية المتعلقة بعلاقة الفرد المسلم بالإمام كالسمع

والطاعة والنصح لولي الأمر ووعظه والجهاد معه ومنهج أهل السنة في معاملة

- الحكام

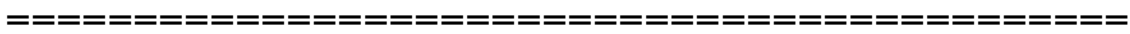

\section{الكلمات المفتاحية}

المضامين ، اجتماعية ، تطبيقات ، تربوية . 


\section{بسم الله الرحمن الرحيم}

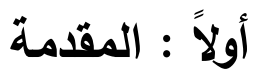

الحمد له هدانا للإسلام وما كنا لنهتدي لولا أن هدانا اله ، أنعم علينا بنعمة

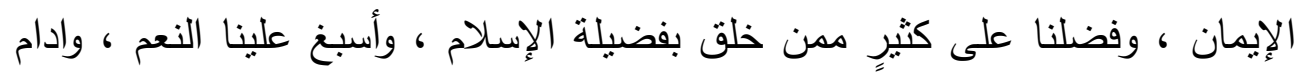

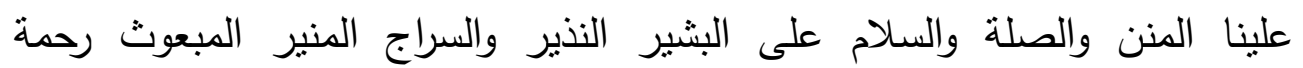

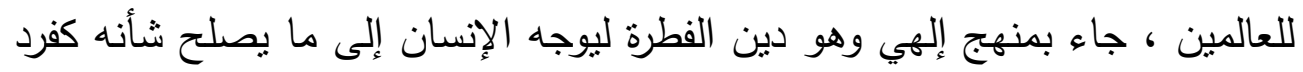

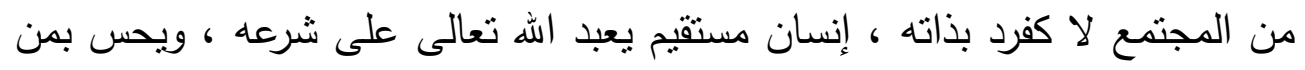

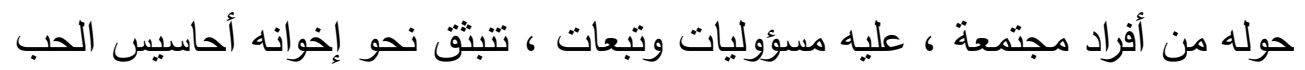

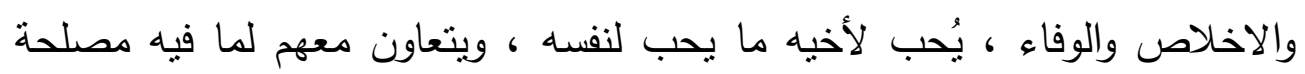

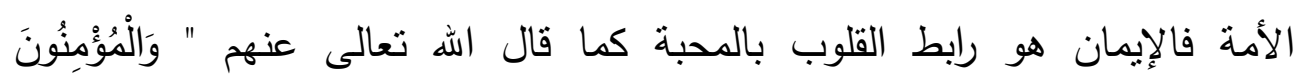

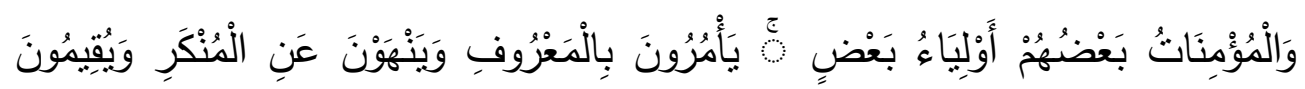

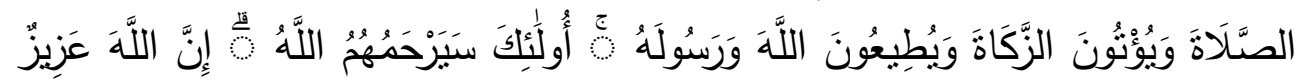

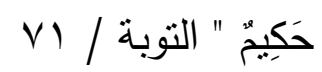

" والمجتمع المسلم عبارة عن عدد هائل من الأفراد المسلمين جمعت بينهم

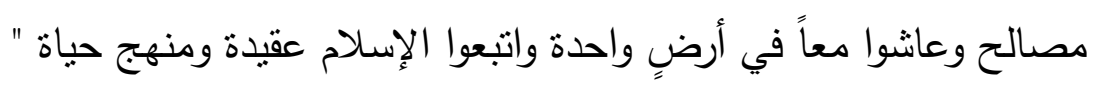

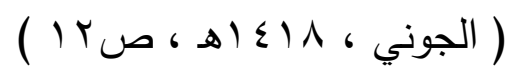

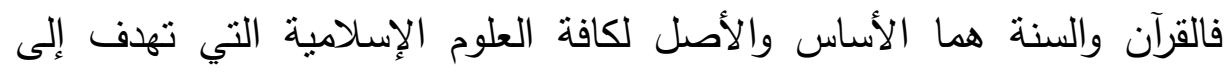

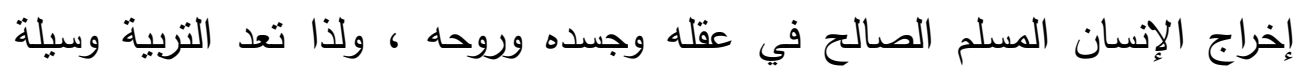

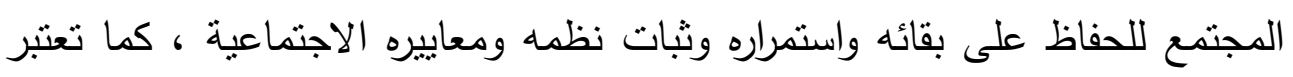

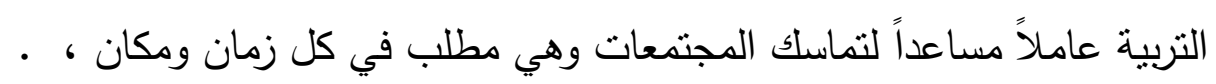

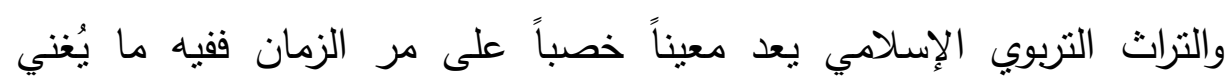

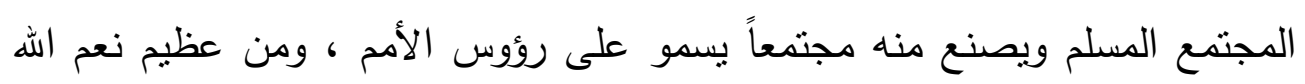


علينا أن هيأ لهذه الأمة في كل حقبة زمنية علماء عاملين ونصحاء مخلصين ، رفع الله شأنهم وخلّد ذكرهم ، رفعهم بالعلم ، وزينهم بالتقوى ، وجعلهم أسوة الناس وقدوتهم

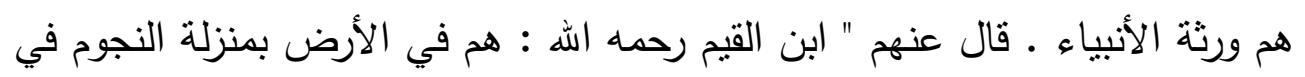
السماء ، بهم يهتدي الحيران في الظمأ ، وحاجة الناس إليهم أعظم من حاجته

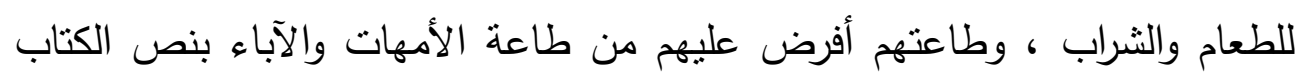

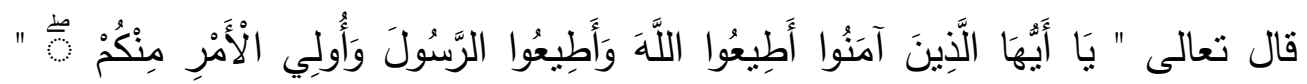

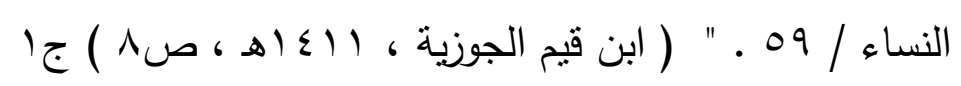
" لذا يعدُّ تراث هؤلاء الفقهاء حصيلة فكرية قيمه نشكل المشهد الثقافي الإسـاهي ، وتسهم في توجيه مساراته على المستوى الفردي والجماعي ، فنتاجهم عملية

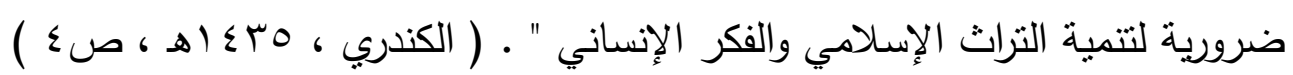
كما أن دراسة المضامين التربوية في جميع جوانبها عند العلماء والمربين في أي الي عصر من العصور يكثف عن الواقع التربوي في العصور التي عاثوا فيها ، والتاريخ حافل بأعداد كبيرة من المربين والعلماء الذين ساهموا في الحضارة الإسلامية وكانت

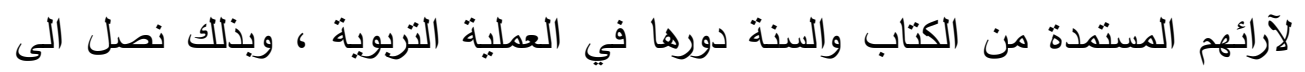
حقيقة مفادها أن علماء المسلمين وضعوا قواعد وأسس التربية في ضوء المنهج الإسلامي ، ومن علماء المسلمين الذين تركوا للأجيال اللاحقة تراثاً تربوياً حافلاً الإمام العلامة الفقيه المُحدّث : أبي عبداله محمد بن مفلح المقدسي المتوفي سنة سا7هـ ، من علماء القرن الثامن الهجري ، كان لله مكانة ومنزلة اجتماعية وعلمية رفيعة " قال عنه ابن كثير : " كان بارعاً ، فاضلاً ، متفنناً في علوم كثيرة " .

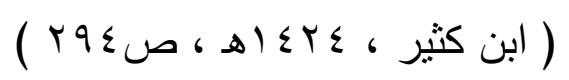

ووصفه ابن القيم بقوله : " ما تحت قبة الفلك أعلم لمذهب الإمام أحمد من ابن

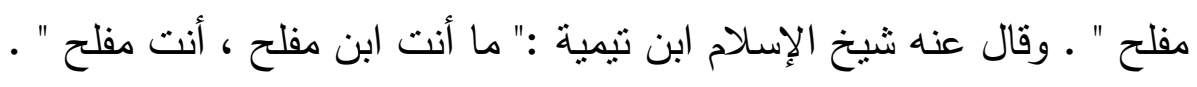

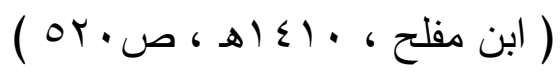


ومن الآثار النافعة لابن مفلح كتابه الثهير \} الآداب الثرعية والمنح المرعية

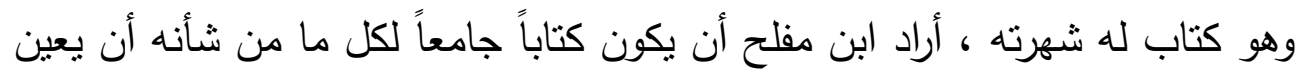
على تحقيق السعادة الإنسانية في الدنيا والأخرة من خلص السير على هدي النهج الرباني الذي ارتضاه الله سبحانه وتعالى لعباده الصالحين •

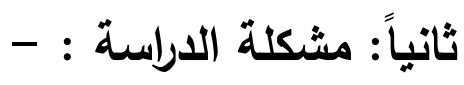
تشتهر في مجال التربية المدارس الغربية الحديثة رغم أن الإسلام منذ عهوده الأولى جاء بأكثر المفاهيم التربوية الحديثة ، وكان لا بد من الكثف عن هذا الطرح

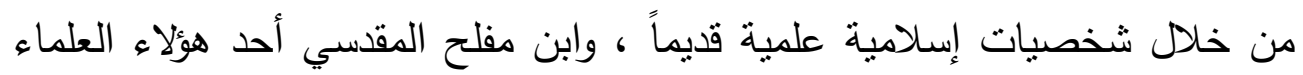
المسلمين الذين اهتموا اهتماما بالغاً بالمضامين التربوية في جميع أبعادها وفي هواءياء

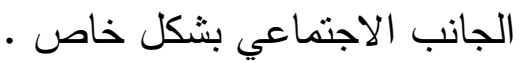
وجاء هذا البحث ليجيب عن تساؤل رئيسي وهو :- ما المضامين التربوية الاجتماعية لصلاح الأمة المستتبطة من كتاب الآداب الثرعية والمنح المرعية لابن مفلح المقدسي وتطبيقاتها في الحياة اليومية ويتقرع عنه بعض التساؤلات الفرعية وهي ا ـ من الامام ابن مفلح المقدسي ومكانة كتابه الآداب الثرعية والمنح المرعية ؟ r. ما المضامين التربوية الاجتماعية المتعلقة بعلاقة الفرد المسلم بوالديه ؟ r. ما المضامين التربوية الاجتماعية المتعلقة بعلاقة الفرد المسلم بسائر المسلمين ؟ ؟ ؟ ع. ما المضامين التربوية الاجتماعية المتعلقة بعلاقة الفرد المسلم بأقاربه ؟ ؟ ؟ 0. ما المضامين التربوية الاجتماعية المتعلقة بحقوق الإنسان ؟ ؟ ؟ 7. ما المضامين التربوية الاجتماعية المتعلقة بالآفات المهددة للمجتمع ؟

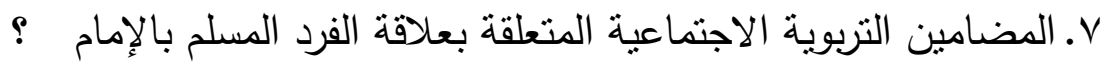

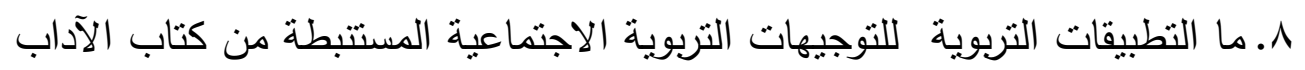
الثرعية في الحياة اليومية . 
ثالثاً :- أهداف الدراسة :- تهدف الاراسة إلى التعرف على :-

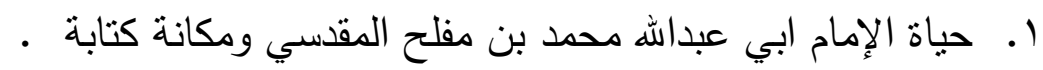

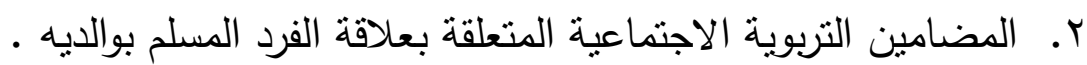

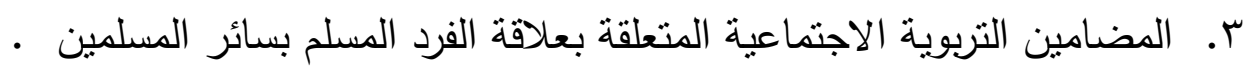

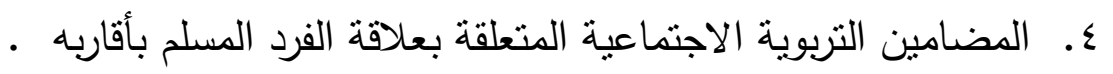

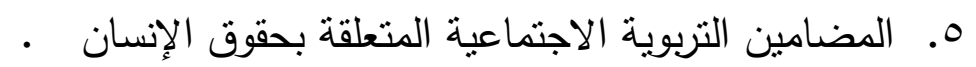

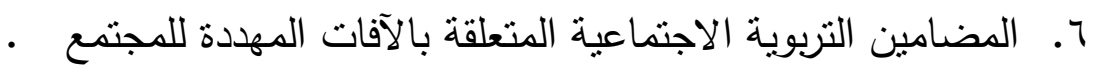

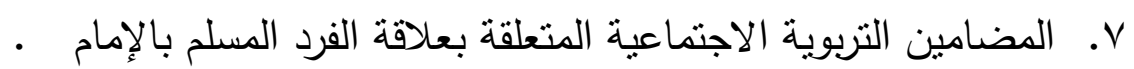

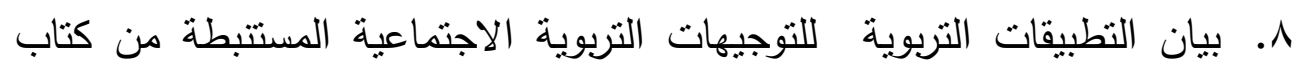

$$
\begin{aligned}
& \text { الآداب الشرعية في الحياة اليومية ؟ } \\
& \text { رابعاً :- أهمبة الدراسة :- الددابه }
\end{aligned}
$$

ا ـ إبراز جهود علماء المسلمين في الجانب الاجتماعي للتربية . r. الحاجة الماسة لدراسة التراث الفكري التربوي الإسلامي لصباغة الرواءئ والافكار

التي تؤطر العمل التربوي الإسلامي في ظل التحديات المعاصرة .

r. إبراز السبق التربوي الإسلامي في إصلاح الأمة والمساهمة الفعلية في ذلك الإسي ء. . الرجوع الى تراثنا الإسلامي الذي شهد خلال تاريخه الطويل الكثير من المتغيرات والتحولات ، فأصبح ذاخراً بالخيرات السابقة التي يمكن الاستفادة منها في

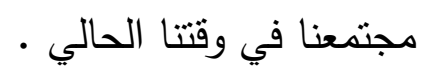

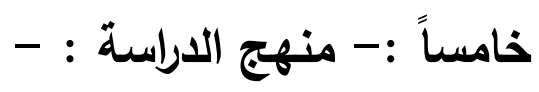

المنهج المستخدم في تحقيق اهداف الدراسة هو المنهج الوصفي الاستتباطي ولقد عرفه ( فوده وآخرون ، ^ • ع اهـ ) و ( الخطابي ، 0 . ع اهـ ) بأنه الطريقة التي يقوم 
فيها الباحث ببذل أقصى جهد عقلي ونفسي عند دراسة النصوص بهدف استخراج

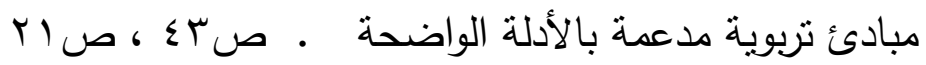

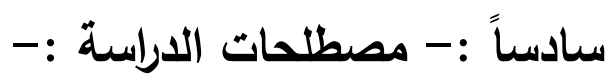

المضامين التزبوية :- هي " خلاصة الفكر التربوي الذي يشتمل عليه كتاب معين بغض النظر عن المجال الرئيسي الذي أُلف فيه هذا الكتاب ، فقد يكون الكتاب

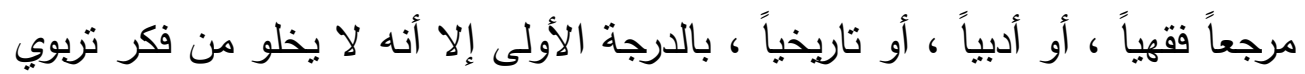

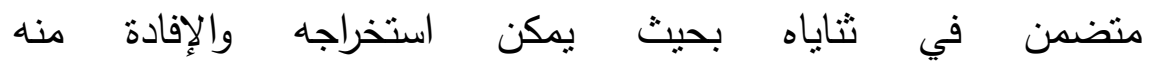

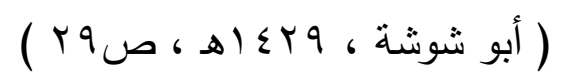

كما تعرف بأنها " كافة المغازي والأنماط والأفكار والقيم والممارسات التربوية التي تتم من خلا العملية التربوية لتنشئة الأجيال المختلفة عليها تحقيقاً للأهداف

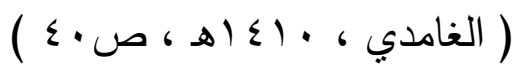
التربوبة المرغوب فيها " والمراد بالمضامين التربوية في هذه الدراسة ما يمكن التعرف عليه من المعاني والتوجيهات التربوية في المجال الاجتماعي التي اشتمل عليها واحتواها كتاب الآداب

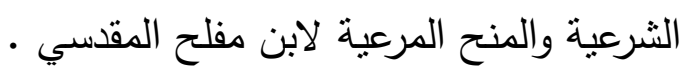

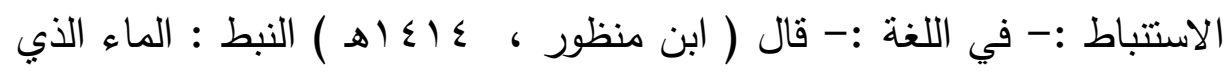
ينبط ( أي يستخرج ) من قعر البئر إذا حفرت ، وقد نبط ماؤها ينبط نبطاً ونبوطاً ،

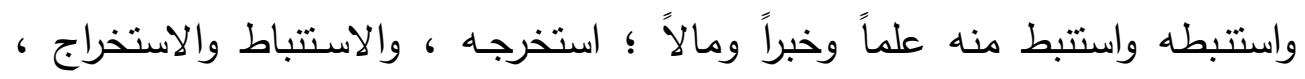
واستتبط الفقيه إذا استخرج الباطن باجتهاده وفهمه . ص • 1 ع ونبط الماء ينبط وينبط نبوطاً : نبع وأنبط الحفار: بلغ الماء والاستنباط الاستخراج والنبط : المـاء الذي ينبط من قعر البئر إذا حفرت .

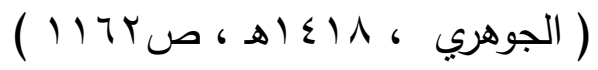
وفي الاصطلاح : " الاستتباط هو استخراج المعاني من النصوص بفرط الذهن

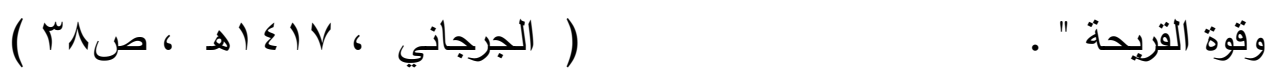


التطبيقات :- في اللغة : التطبيق في اللغة من طبق الثيء على الثيء إذا نزاه عليه بحيث يستوعبه بكامله دون زيادة أو نقصان ، ومنه تطبيق اليدين يجعل إحداهما على الأخرى ، ومنه طبق الغيم تطبيقاً إذا أصاب بمطره جميع الأرض ل

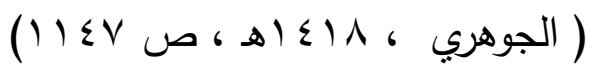

كما يعرف التطبيق : " بأنه إخضاع المسائل والقضايا لقاعدة علمية أو قانونية

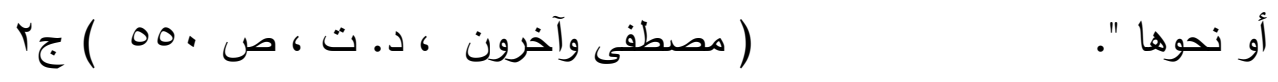

في الاصطلاح : " مقابلة الفعل بالفعل ، والاسم بالاسم ، ويقال له أيضاً :

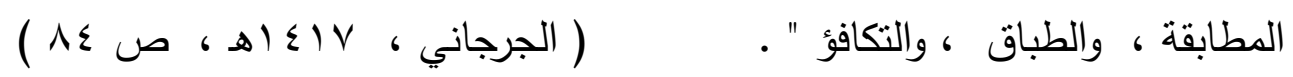
التطبيقات التربوية :- ويقصد بها في الدراسة : مجمل الخطوات الإجرائية التي تقوم بها الأسرة والمهتمين بمجال التربية لتربية النشء على تحقيق المضامين التربوية والاجتماعية لصلاح الأمة المستتبطة من كتاب الآداب الثرعية والمنح المرعية لابن

$$
\begin{aligned}
& \text { مفلح المقدسي لتصبح ممارسات وسلوكيات في واقع الحياة . } \\
& \text { سابعاً :- حدود الدراسة : - - }
\end{aligned}
$$

تقتصر الدراسة في حدود كتاب الآداب الثرعية والمنح المرعية لابن مفلح المقدسي والاقتصار على المضامين التربوية الاجتماعية لإصلاح الامة من خلال ابراز علاقة الفرد المسلم بوالديه ، علاقة الفرد المسلم بسائر المسلمين ، علاقة الفرد المسلم بأقاربه ، حقوق المحتاجين على الفرد المسلم ، حقوق الإنسان ، الآفات المهددة للمجتمع ، علاقة الفرد المسلم بالإمام ، وابراز تطبيقاتها التربوية في الحياة اليومية الية

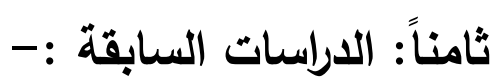
بعد البحث في المكتبة التربوية ، ومصادر البحث العلمية ، من خلال الاتصال بمعهد البحث العلمي في جامعة أم القرى ، ومركز الملك فيصل للبحوث والدراسات 
الإسلامية ، وفهارس مكتبة الملك فهد الوطنية ؛ تبيّن أن المضامين التربوية والاجتماعية لصلاح الأمة المستنبطة من كتاب الآداب الثرعية والمنح المرعية لابن مفلح المقدي وتطبيقاتها في الحياة اليومية لم يسبق دراسته من قبل بهذه الوجهة التزبوية الاجتماعية المتخصصة ، وأن ما وجدته من الدراسات ذات الصلة أو العلاقة كانت على النحو النالي :-

ا. دراسة محمد أحمد بحيري أبو هواش ( باءـأه ) بعنوان المنهج الأخلاقي عند ابن مفلح وتهدف هذه الدراسة إلى إبراز شخصية ابن مفلح في تعديق الاتجاه السلفي ،

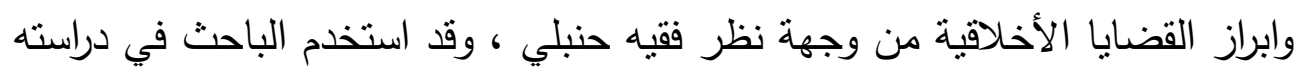
المنهج الوصفي التحليلي تجاه النصوص ، ومن أهم النتائج التي توصلت إليها الدراسة وجود مجال رحب للدراسات الأخلاقية في كل من الفقه وأصوله ، أصالة الأخلاق الإسلامية النابعة من الكتاب والسنة ، وجود نظرية عامة وشاملة للأخلاق في الإسلام بجانب هذا التراث من النواحي العلمية للأخلاق وغيرها . تختلف هذه الدراسة مع الدراسة الحالة في أنها تبرز القضايا الأخلاقية عند ابن مفلح المقدي ، أما الدراسة الحالية فتبرز المضامين الاجتماعية عند الإمام ابن مفلح • المقدسي وتتفق هذه الدراسة مع الدراسة الحالية في أن كلا الدراستين تبرز ملامح شخصية ابن مفلح المقدسي - (بقد

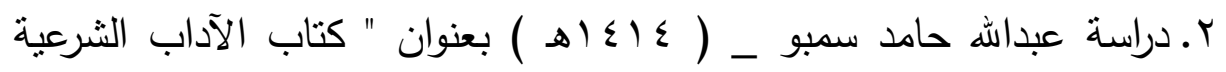
والمصالح المرعية لابن مفلح المقدي الحنبلي المتوفي سنة ( سجVهـ ) دراسة وتحقيق الجزء الأول من الكتاب الى نهاية فصل ( قد سبق الكلام في بر الوالدين ) . وتهدف هذه الدراسة إلى دراسة سيرة ابن مفلح والتعريف بكتاب الآداب الثرعية والمصالح المرعية ، ولم يذكر الباحث المتبع في الدراسة ، ومن أهم النتائج التي rAv 
توصلت إليها الدراسة أن كتاب ابن مفلح من أجمع الكتب المؤلفة في الأخلاق

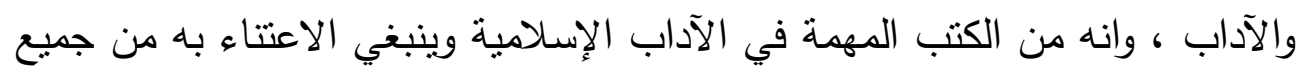
جوانبه . تختلف هذه الدراسة مع الدراسة الحالة في أنها تحقيق ودراسة للجزء الأول من

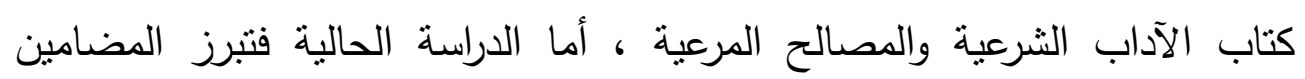

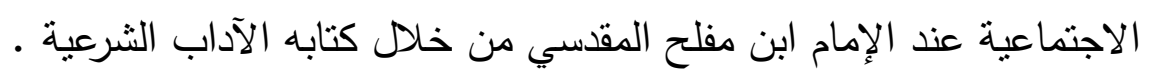

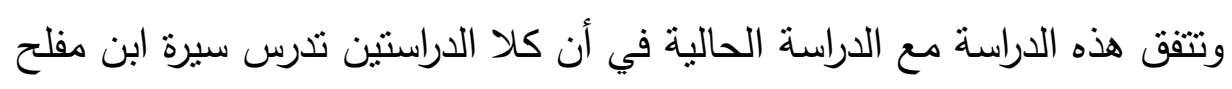

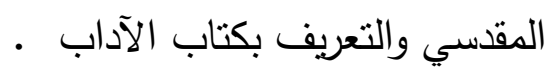
واستفادة الباحثة من هذه الدراسة في دراسة سيرة ابن مفلح وكتابه الآداب الثرعية

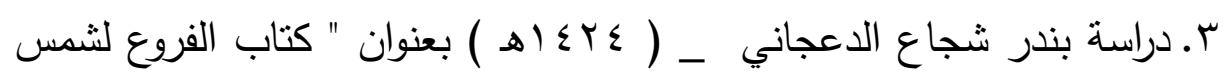

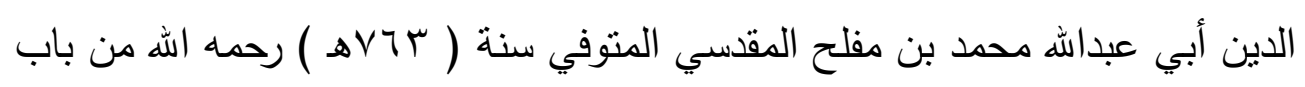

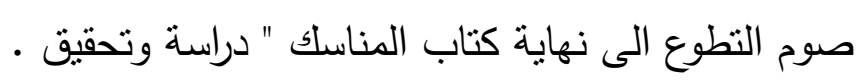

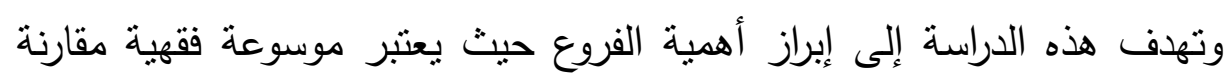

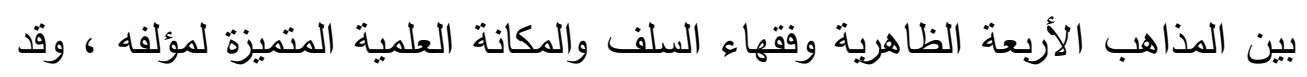

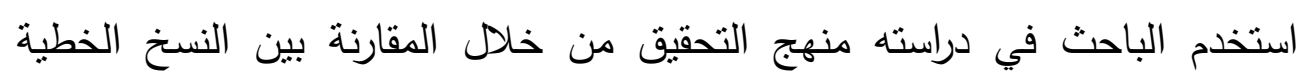

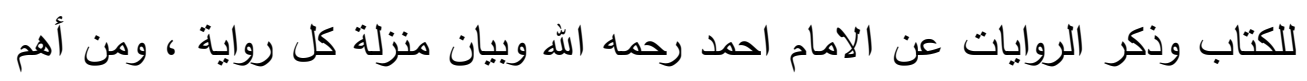

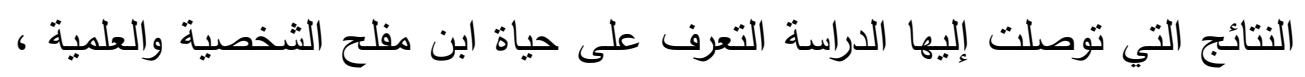

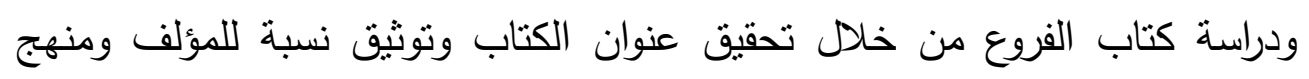

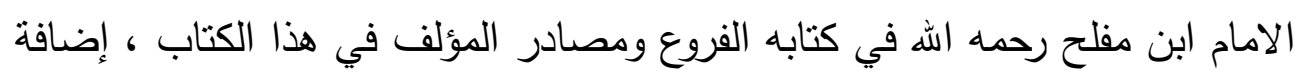

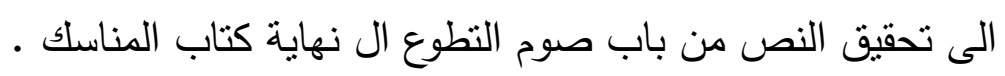

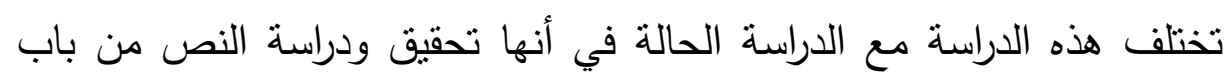

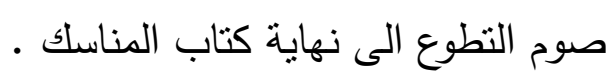


وتتفق هذه الدراسة مع الدراسة الحالية في التعرف على حياة ابن مفلح الثخصية

والعلمية .

واستفادة الباحثة من هذه الدراسة في دراسة سيرة ابن مفلح الثخصية والعلمية .

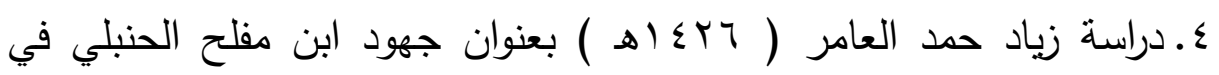

• تقرير العقيدة

وتهدف هذه الدراسة إلى إبراز جهود ابن مفلح في تقرير عقيدة أهل السنة والجماعة ، ومدى موافقته للسلف ، وقد استخدم الباحث في دراسته المنهج الوصفي الاستقرائي ، ومن أهم النتائج التي توصلت إليها الدراسة تميز ابن مفلح في حياته الثخصية بالطابع الديني فوالده أحد العباد ، وزوجه من أسرة علماء ، وخرج علماء من ذريته ، أما حياته العلمية فتميزت بالنفع الكبير ، لمؤلفاته المشهورة كالفروع والآداب الثرعية ، وافق ابن مفلح السلف في مصادر التلقي ومناهج الاستدلال في الجملة وفي توحيد الربوبية والاسماء والصفات والألوهية في الجملة ، وخالف السلف في الاستدلال بخبر الواحد وفي أول واجب على المكلف وبعض مسائل تعظيم القبور والتمائم وفي مسألة حكم التقليد في الإيمان ـ تختلف هذه الدراسة مع الدراسة الحالة في أنها تبرز جهود ابن مفلح في تقرير العقيدة ، أما الدراسة الحالية فتبرز المضامين الاجتماعية عند الإمام ابن مفلح المقدسي • ونتفق هذه الدراسة مع الدراسة الحالية في أنها تتعرّف على حياة ابن مفلح المقدسي ونشأنه. ه. دراسة بدر بن جزاع بن نايف النماصي ( سrء اهـ ) بعنوان آداب المعلم والمتعلم عند الإمام ابن مفلح من خلا كتابه الآداب الثرعية والمنح المرعية وتطبيقاتها في الواقع المعاصر • وتهدف هذه الدراسة إلى التعرف على آداب المعلم والمتعلم عند الإمام ابن مفلح من خال كتابه الآداب الثرعية ، وقد استخدم الباحث في دراسته المنهج التاريخي rAq 
الاستتباطي لاستقراء واستتباط الفكر التربوي ، ومن أهم النتائج التي توصلت إليها الدراسة أهمية الآداب التي ينبغي أن يتحلى بها المعلم والمتعلم لإنجاح العملية التعليمية ، فالآداب التي ذكرها ابن مفلح يمكن اتخاذها قواعد لمهنة التربية والتعليم في عصرنا الحاضر ، والتي يمكن الاستفادة منها في برامج اعداد المعلم وتهيئة المتعلم حيث حذّر من الأمراض الاجتماعية التي تنبب الفرقة في المجتمع المدرسي برني كالغيبة والنميمة والكذب والسخرية والنفاق والاستهزاء بالآخرين مما ينعكس أثره سلباً

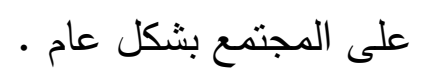
تختلف هذه الدراسة مع الدراسة الحالة في أنها تبرز آراء ابن مفلح بالنسبة للمعلم

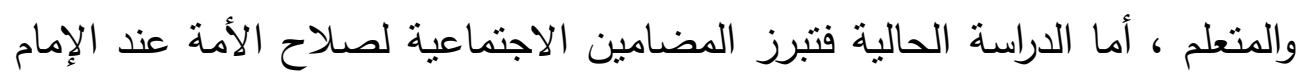
ابن مفلح المقدسي. وتتقق هذه الدراسة مع الدراسة الحالية في أنها تتعرف على حياة ابن مفلح المقدسي ونشأته. تاسعاً :- الإطار النظري للاراسة :- المبحث الأول :- التعريف بالأمام ابن مقلح :

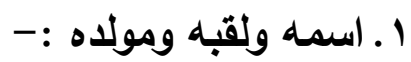

هو الإمام العلامة الققيه أبو عبدالله شمس الدين محمد بن مفلح بن محمد المقدسي ، ثم الصالحي ، الراميني ، شيخ الحنابلة في وقته ، ولد في حدود سنة عشر الإمر وسبعمائة ، وسمع من عيسى المطعم ، وله مشايخ كثيرون ، منهم : البرهان الزرعي

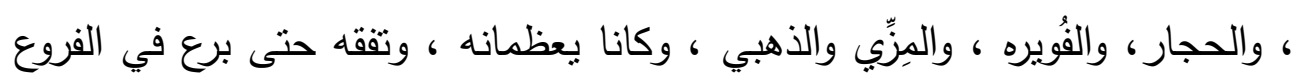
على مذهب الإمام أحمد ، وأصهر إلى العلامة جمال الدين المرداوي قاضي قضي ولهاة

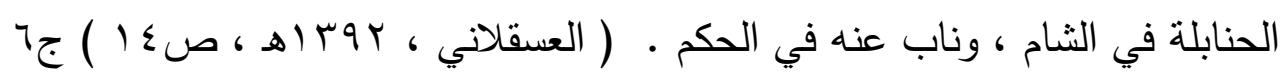


وقد ذكره الذهبي فقال: شابٌٌ دَيِّنُ عالِم ، له عمل ونظر في رجال السنن ، ناظر

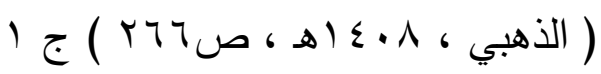

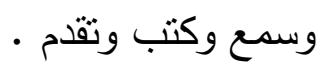

وذكر قاضي القضاة المرداوي أنه قرأ عليه المقنع وغيره من الكتب في علوم شتى ، ووصفه ابن القيم بقوله : ما تحت قبة الفلك أعلم بمذهب الإمام أحمد من ابن

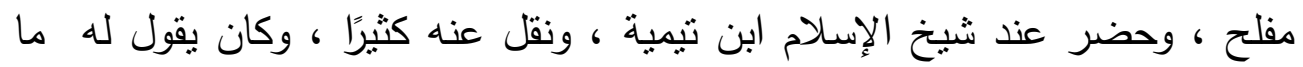

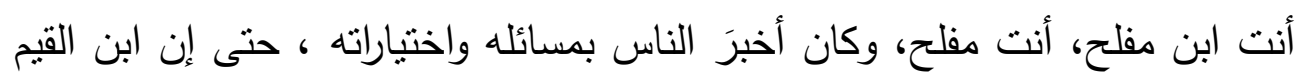

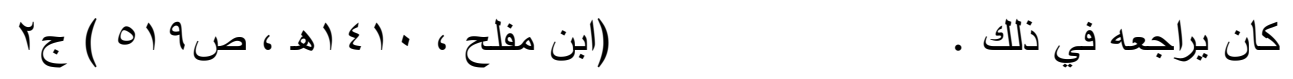
r ـ نشأته :- ولد ونشأ في بيت المقدس ، وتوفي بصالحية دمشث .

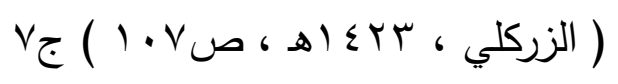

وقد درس بالصاحبة ، ومدرسة الثيخ أبي عمر، والسلامية ، وأعاد بالصدرية

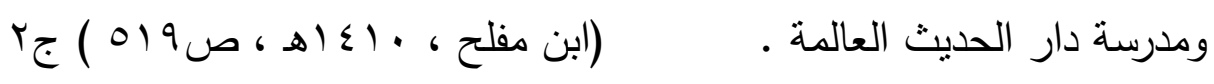

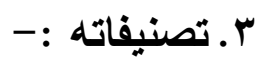

كان لله العديد من التصانيف النافعة ، والمصنفات الجامعة ، منها " كتاب الفروع - ط ، ثناث مجلدات في الفقه ، وكتاب النكت والفوائد السنية على مشكل المحرر

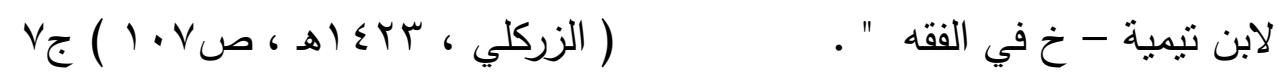
وله كتاب في أصول الفقه ، وهو كتاب جليل حذا حذو ابن الحاجب في مختصره وفيه من النقول والفوائد ما لا يوجد في غيره ، وليس للحنابلة أحسن منه .

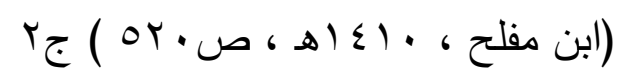

ومن كتب الإمام ، كتاب " الآداب الثرعية والمنح المرعية " ويسمى الآداب الكبرى ، فهو ذو قيمة علمية كبيرة ؛ لأنه كما جاء في مقدمة العلامة محمد رشيد رضا لكتاب الآداب الثرعية في طبعته السابقة " مستمد من الكتاب والسنة وآثار العُبَّادِ والزُّهاد من السلف الصالح ، وأن المدار في أحكامه الفقهية وآدابه الثرعية 
على ما كان عليه الإمام أحمد بن حنبل رحمه الله الذي كان في غاية التمسك بالهدي

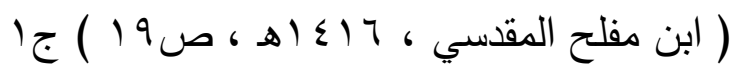
النبوي • يقول ابن مفلح رحمه الله في خطبة الكتاب وهو يتحدث عن هذا الكتاب: " قد اشتمل هذا الكتابُ بحمد الله وعونه وحُسن توفيقه على ما تضمَّنته المصنفات السابقة له أو على أكثرها ، فمَن علمِه علمِ قدره ، وعلم أنه قد علم من الفوائد المحتاج إليها ما لم يعلم أكثز الفقهاء ، أو كثير منهم ؛ لاشتغالهم بغيره ، وعزة الكتب الجامعة لهذا

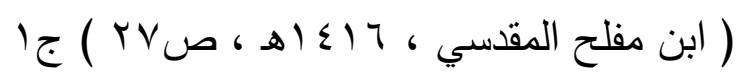

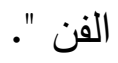
المبحث الثاني :- المضامين التربوية والاجتماعية لصلاح الأمة المستنبطة من كتاب الآداب الشرعية والمنح المرعية لابن مقلح المقدسي المضامين التربوية الاجتماعية تهدف الى التعرف على المعاني والتوجيهات التربوية في المجال الاجتماعي التي اثتمل عليها واحتراها كتاب الآداب الثرعية والمنح المرعية لابن مفلح المقدسي • " وهي الجزء التزبوي الذي يتعامل معه الفرد ، وهي التي تصنع السلوك بما تمد به الأفراد من الأفكار والقيم والآراء والمعتقدات وهي تتشكل وفق رغبة المجتمع ، أي

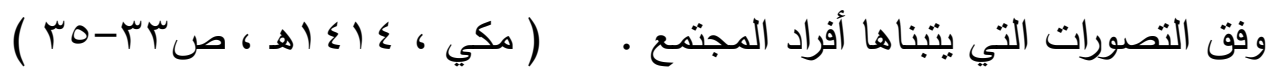
ومن المضامين التربوية الاجتماعية لصلاح الأمة التي توصلت إليها الدراسة ما :- 
المطلب الأول :- ما المضامين التريوية الاجتماعية المتعلقة بعلاقة الفرد

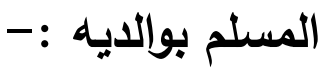

تتضمن علاقة الفرد المسلم بوالديه مجموعة من الواجبات والتي تتمنل في حقوق

$$
\begin{aligned}
& \text { الآباء على الأبناء ومنها :-- } \\
& \text { ا بر الوالدين : - بك اهـاء }
\end{aligned}
$$

البر لغة :- " البرُّ، الخير والفضل ، يقال : برُّ الرجُل ، يبرُّ براً ، فهو برٌّ وبارٌ

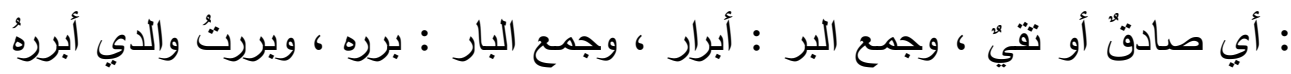

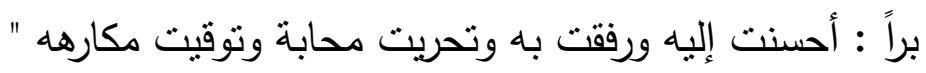

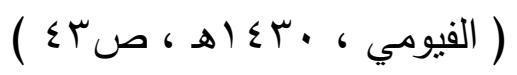

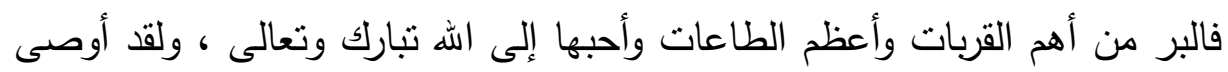

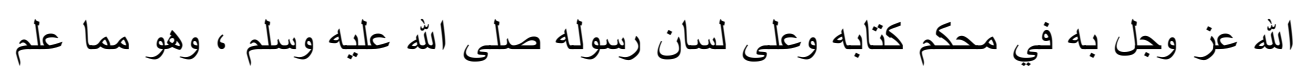

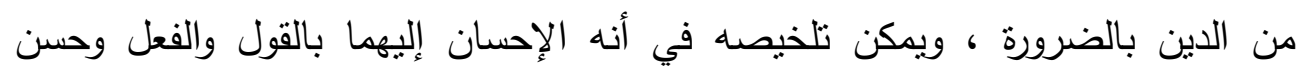

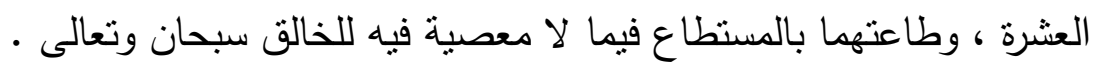

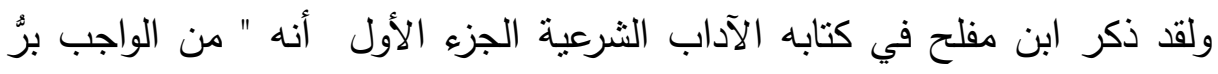

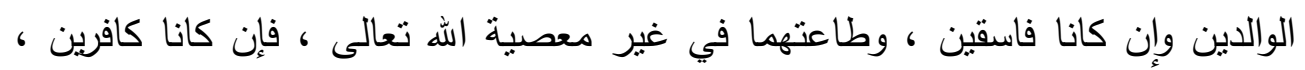

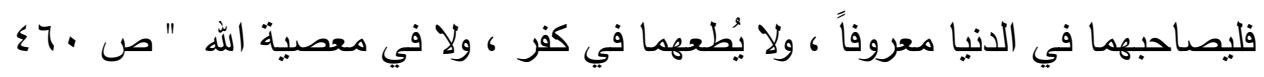

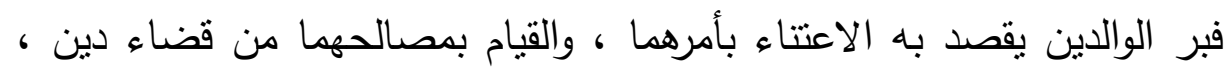

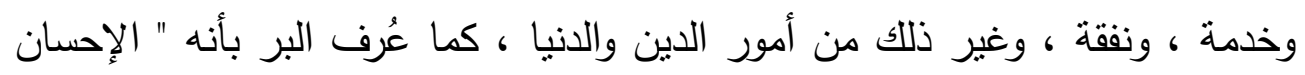

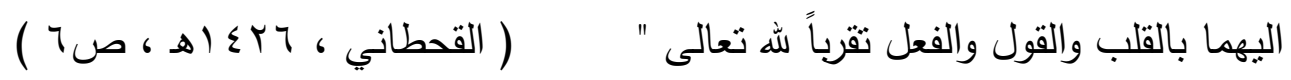

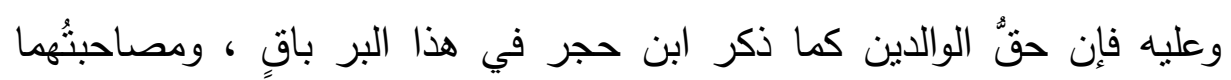

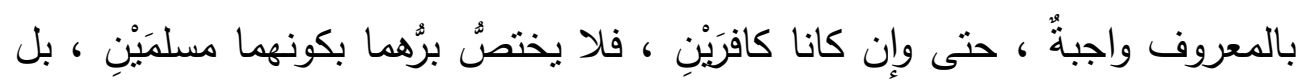

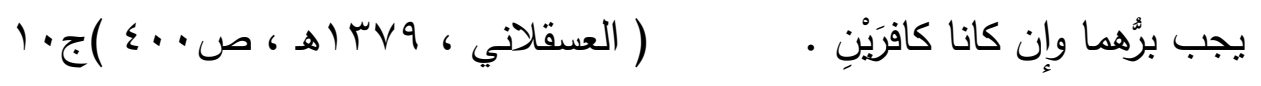




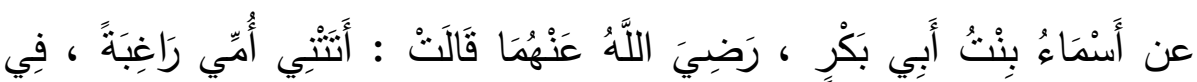

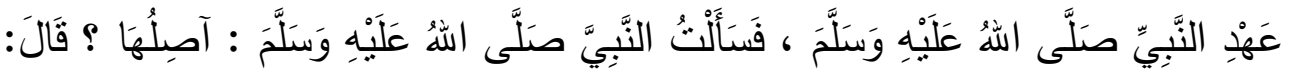

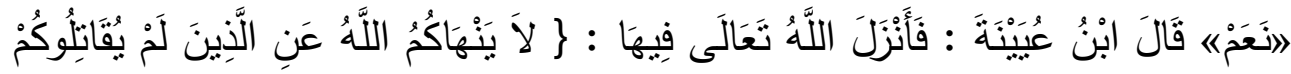

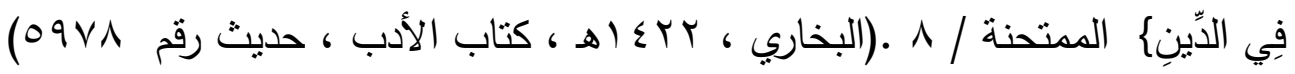

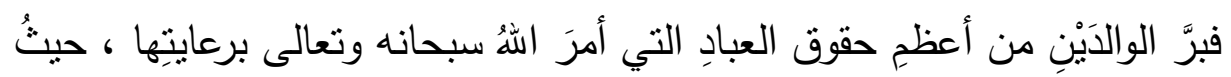

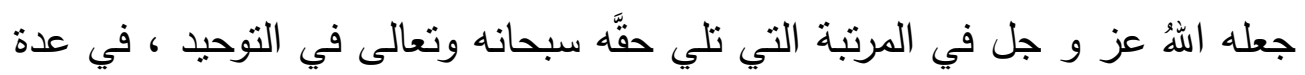

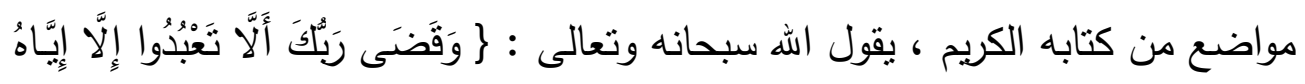

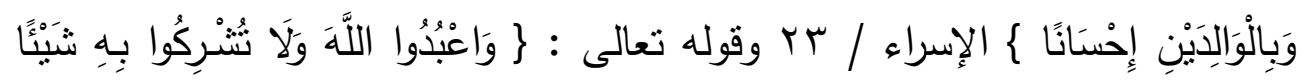

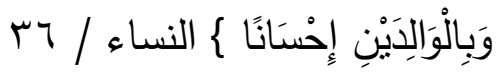

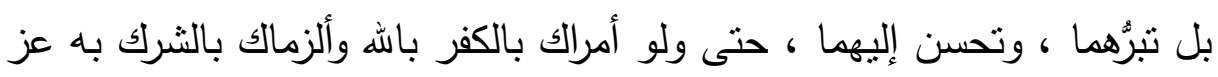

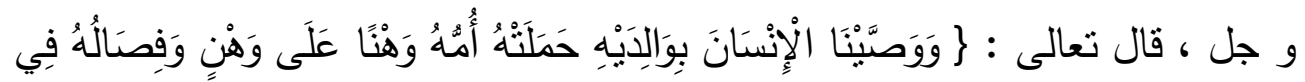

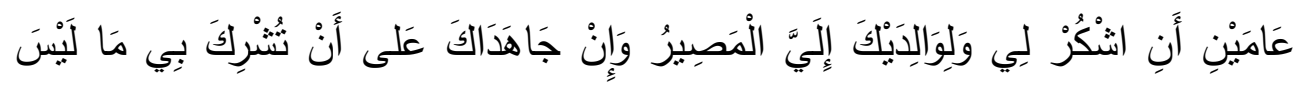

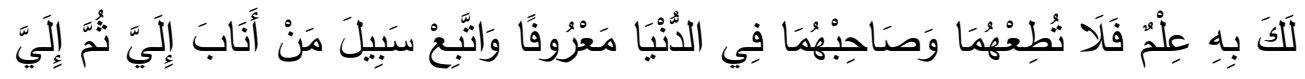

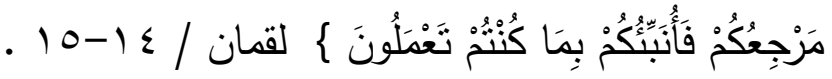

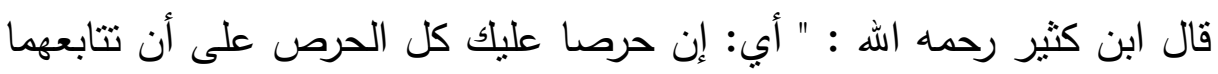

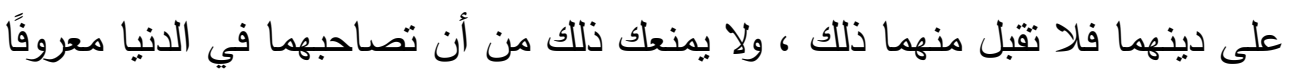

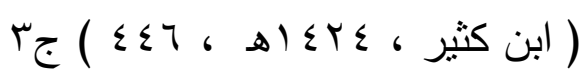

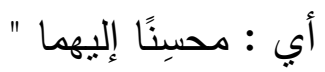
فإذا كان هذا هو موقف الإسلام من برّ الوالدين ، حيث أمرَ بمصاحبَّة هذَيْنِ

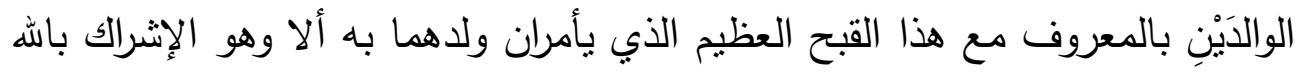

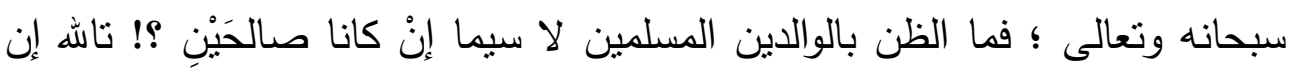

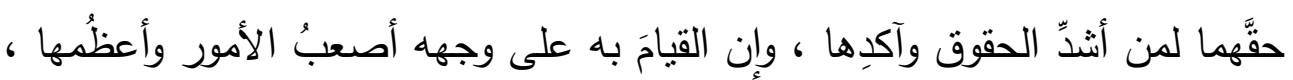

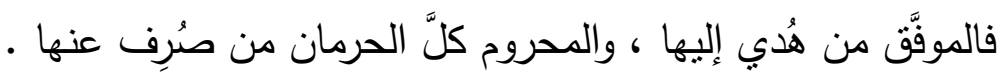

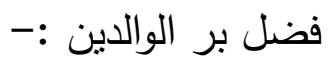




\section{ا ـبر الوالاين سنة الأنبياء - :}

من صفات الأنبياء عليهم السلام بر الوالدين ، وقد أمرنا سبحانه وتعالى في

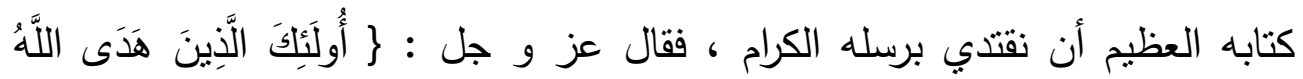

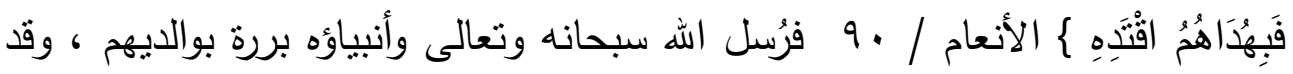
حكى الله عز و جل ذلك عنهم في كتابه الكريم ، فقال عز من قائل يقول نوح عليه

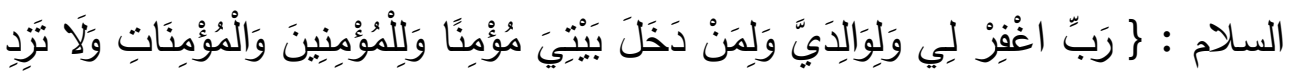

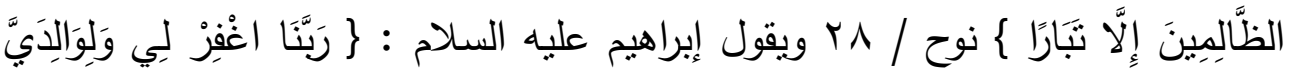

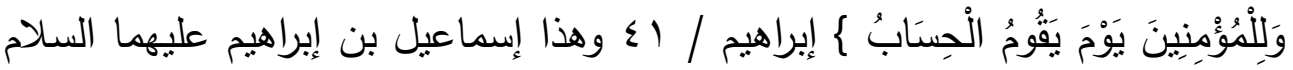

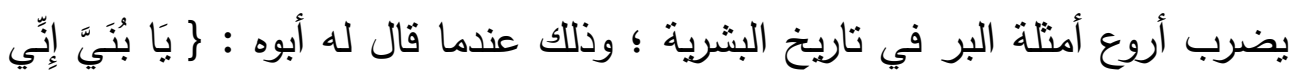

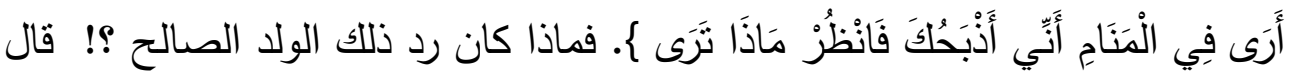

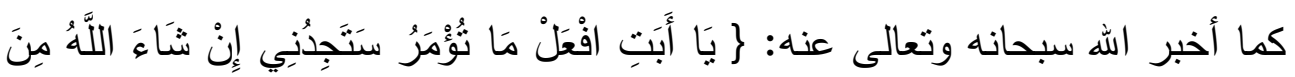

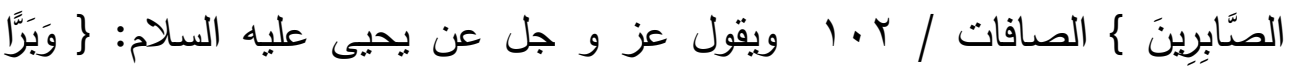

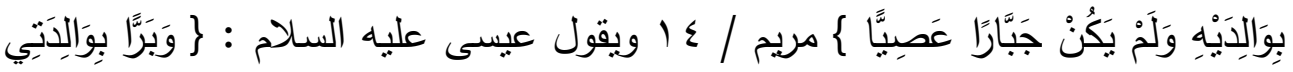

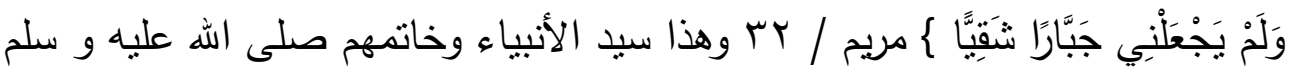

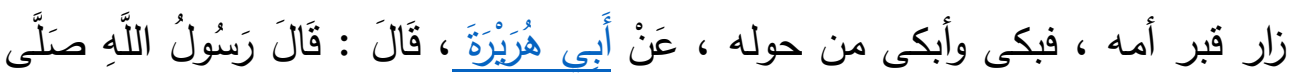

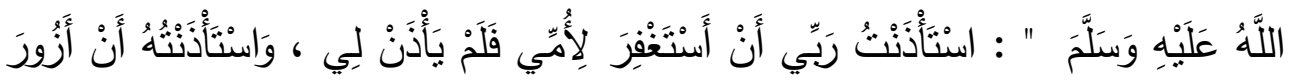

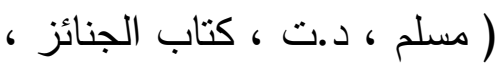

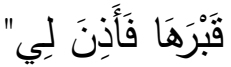

حديث رقم

r.قرن الله عز و جل بر الوالدين بالتوحيد و برضاه :-

حيث جعله الله في المرتبة التي تلي حقه سبحانه في التوحيد ، فقال سبحانه

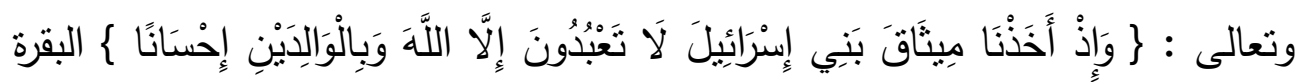
Ar/ 
لذا فإن رضا الرب من رضا الوالدين : قال رسول الله صلى الله عليه و سلم :" رضا الله في رضا الوالد ، وسخط اله في سخط الوالد " .

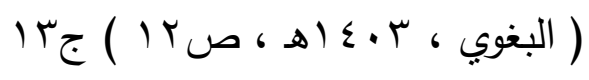

وبر الوالدين مقدَّم على الجهاد في سبيل الله الذي هو ذروة سنام الإسلام ، فعن عبد الله بن عمرو بن العاص رضي الله عنهما قال : جَاءَ رَجُلْ إِلَى النَّبِِّ صلى الله

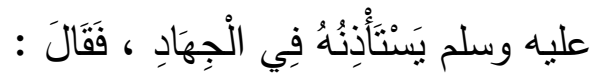

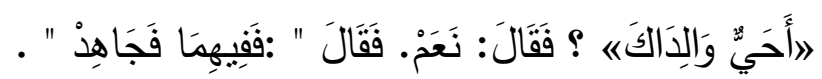

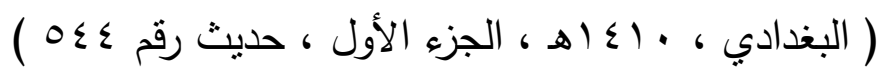

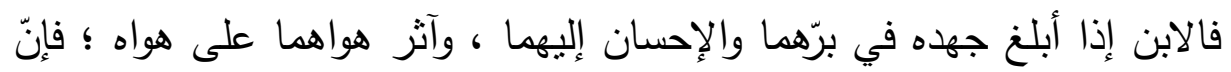
ذللك يقوم مقام قتال العدو ، فبر الوالدين يستمرّ في ذرية الإنسان وعقبِه من بعده ، عن ابن عمر رضي الله عنهما قال: قال رسول الله صلى الله عليه و سلم : " بروا آباءكم تبركم أبناؤكم ، وعِفورا تعِفِ نساؤكم " .

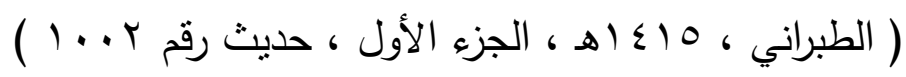

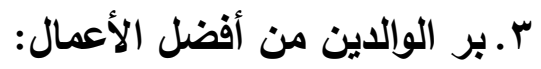

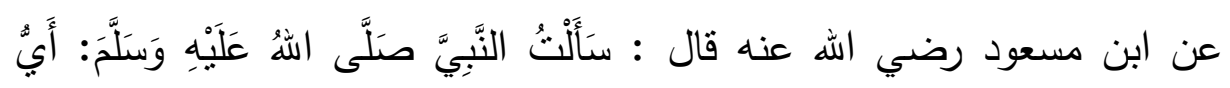

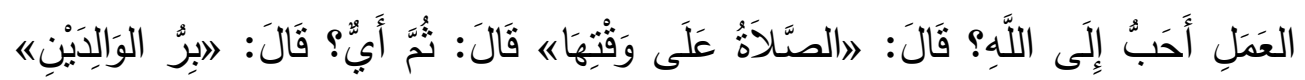

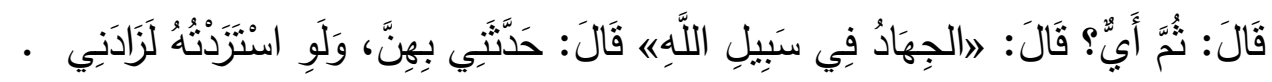

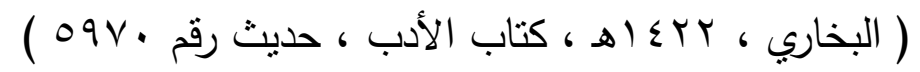

$$
\text { وقد أورد ابن مفلح المقدسي في بر الوالدين ما يلي :- }
$$

اولاً :- طاعة الوالدين في غير معصبة الخالق :- لقد أوجب الله سبحانه وتعالى طاعة الوالدين مقيدةً بعدم معصيته سبحانه وتعالى ، فالوالدين لهما الفضل في

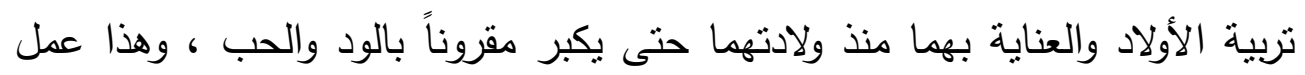
يستحقا عليه البرَّ والطاعة . 
ومما ذكره ابن مفلح في كتابه الآداب الثرعية الجزء الأول بهذا الثأن ، " قال أحمد في رواية هارون بن عبداله في غلام يصوم وابواه ينهيانه : ما بعجبني أن يصوم إذا نهياه ، لا أحب ان ينهياها ، يعني : عن التطوع ، وقال في رواية أبي

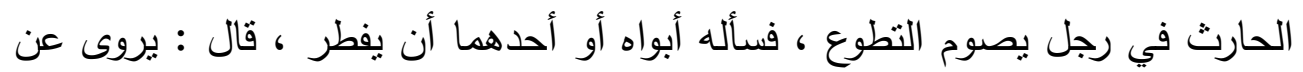

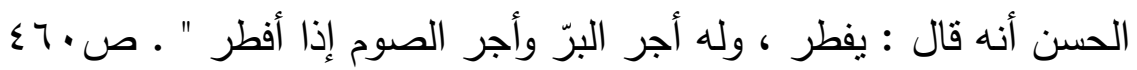

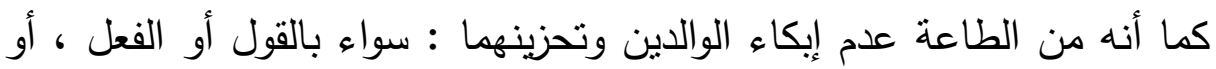
بالتسبب في ذلك ، وذكر ابن مفلح قال أبو بكر في زاد المسافر : من أغضب والديه

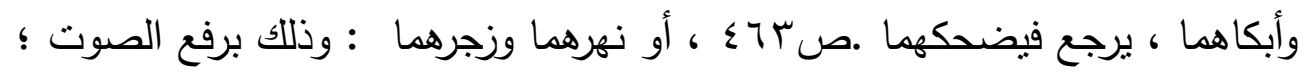
والإغلاظ عليهما بالقول ، والتأفف والتضجر من أوامرهما ، أو العبوس وتقطيب الجبين أمامهما ، أو سبهما ، كما يجب غض الطرف عن زلاتهما ومصاحبتهما

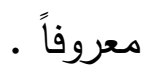
ثانياً :- استئذان الوالدين في طلب العلم :- من أهم فضائل العلم أنه إرث الأنبياء ، فالأنبياء عليهم الصلاة والسلام لم يورثوا درهماً ولا ديناراً وإنما ورثوا العلم فمن أخذ بالعلم فقد أخذ بحظ وافر من إرث الأنبياء، فأنت الآن في القرن الخامس عشر إذا كنت من أهل العلم ترث محمداً - صلى اله عليه وسلم وهذا من أكبر

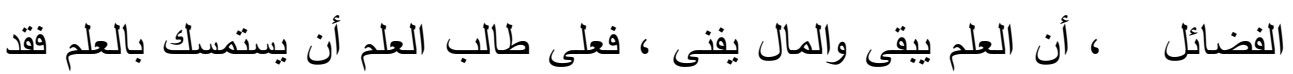
ثبت في الحديث أن النبي - صلى الله عليه وسلم قال: " إذا مات الإنسان ، انقطع عمله إلا من ثلاث ، صدقة جارية أو علم ينتفع به ، أو ولد صالح يدعو له ".

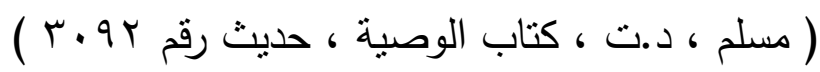
كما أن العلم لا يتعب صاحبه في الحراسة ، فالعلم يحرسك ولكن المال أنت تحرسه تجعله في صناديق وراء الإغلاق ومع ذلك تكون غير مطمئن عليه ، أن أهل العلم هم القائمون على أمر الله تعالى حتى تقوم الساعة ، ويستدل لذلك بحديث

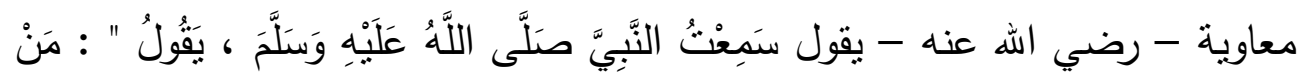
rqv 


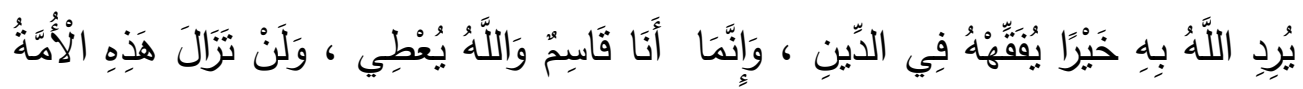

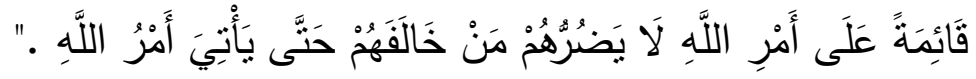

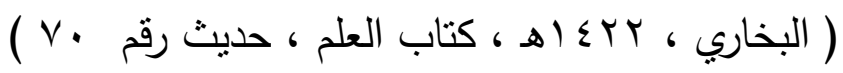

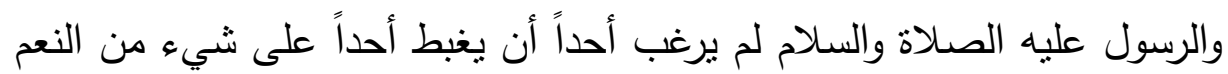

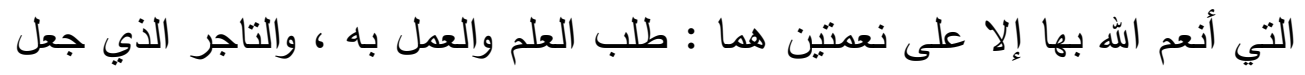

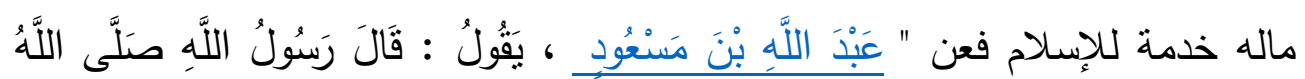

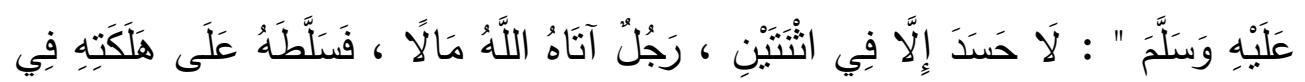

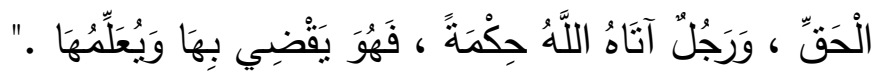

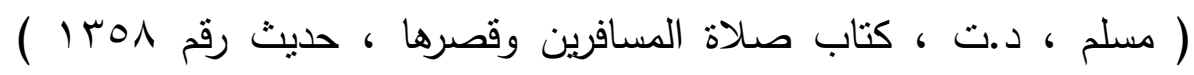

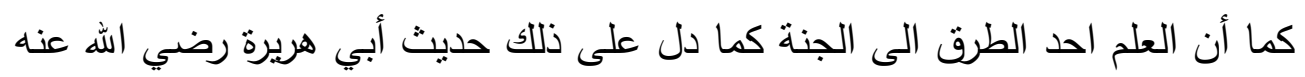

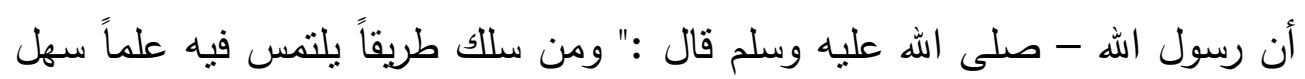

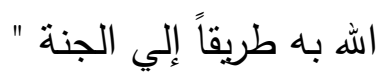

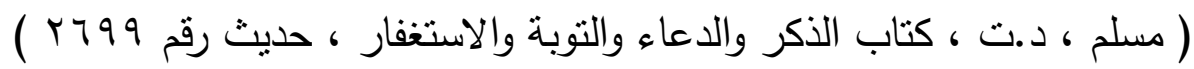
العلم نور يستضيء به العبد فيعرف كيف يعبد ربه ، وكيف يعامل عباده ، فتكون مسيرته في ذللك على علم وبصيرة . ومما ذكره ابن مفلح في كتابه الآداب الثرعية الجزء الثاني بهذا الثأن " وقال

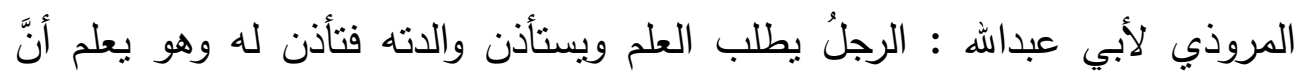

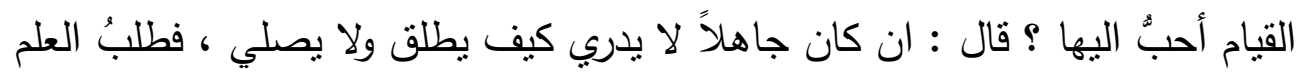

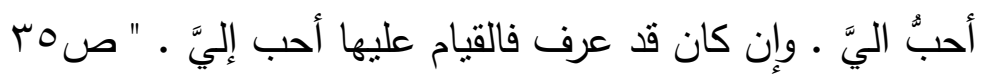

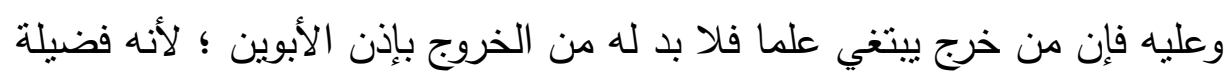

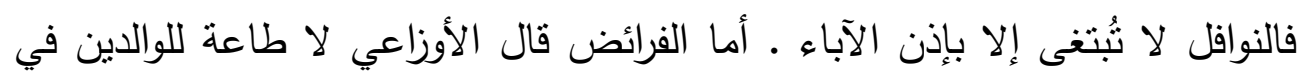

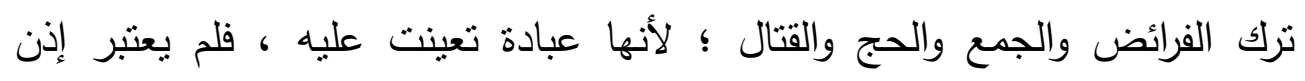


الأبوين فيها ، كالصلاة ، ولأن الله تعالى قال : ( ولله على الناس حج البيت من استطاع إليه سبيلا ) ولم يشترط إذن الوالدين "

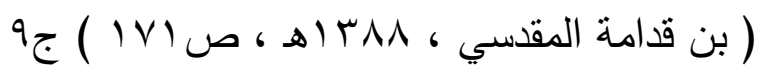

ثالثاً:- الاستغفار للوالدين :- فالاستغفار هو طلب المغفرة ، وقول الإنسان أستغفر الهه معناه أطلب المغفرة من الله ، والاستغفار للوالد المتوفى مأمور به ، وهو من البر به في حياته و بعد موته ، ولقد ورد الأمر الصريح في كتاب الله سبحانه وتعالى بالاستغفار للوالدين وطلب الرحمة لهما يقول الله سبحانه وتعالى : ـ وَاخْفضْ

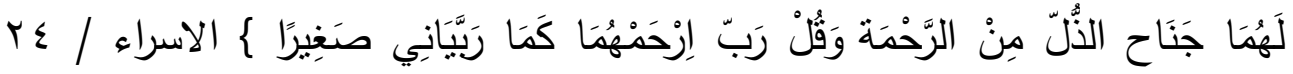

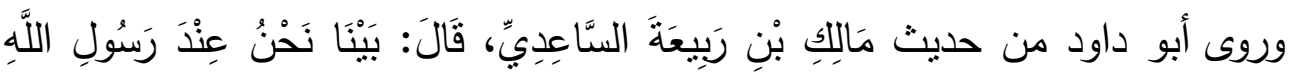

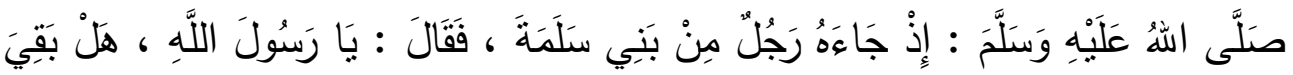

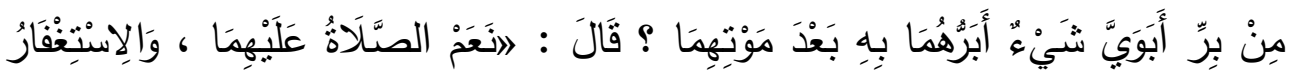

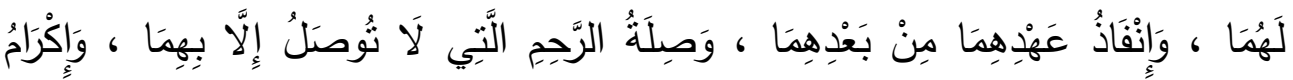

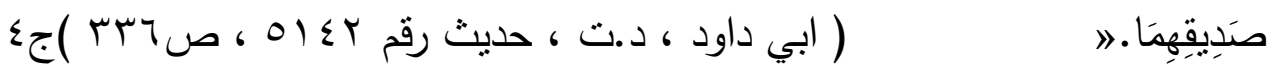

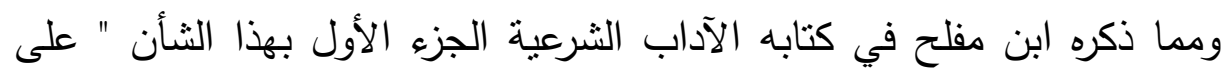

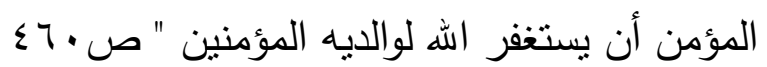
رابعاً :- صلة رحم الوالدين :- صلة الرحم أمر كبير في الإسلام .. أكد عليه القرآن والسنة كثيرًا، وتوعَّدا قاطعي أرحامَهم.. قال الله - عز وجل : - - مَاتَقَّوا الله

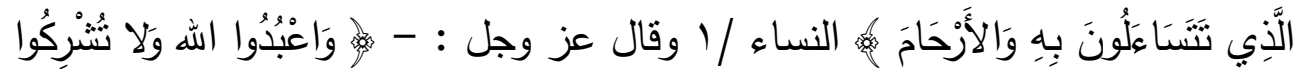

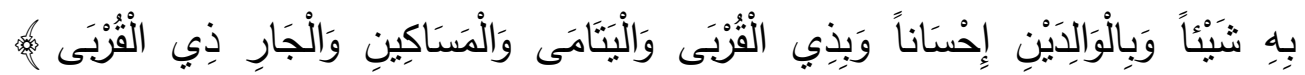
النساء/ ب ، وعن أبي هربرة - رضى الله عنه - عن النبي - صلى الله عليه وسلم - قال: " إن الله خلق الخلق حتى إذا فرغ من خلقه قالت الرحم : هذا مقام العائذ بك الك من القطيعة ، قال : نعم ، أما ترضين أن أصل من وصلك وأقطع من قطعك ؟ قالت 
: بلى يا رب ، قال : فهو للك ". قال رسول الله - صلى الله عليه وسلم -: "فاقرؤوا

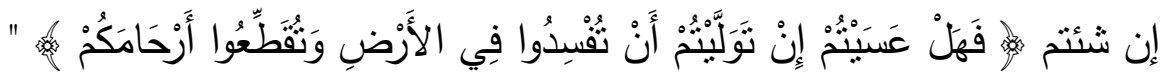

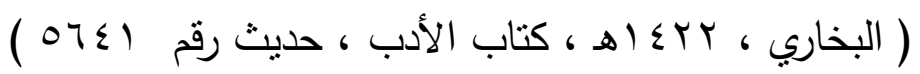

وعن عبد الرحمن بن عوف - رضى الله عنه - قال : سمعت رسول الله -

صلى الله عليه وسلم - يقول : " قال الله تعالى : أنا الرحمن وهي الرحم ، شققت لها

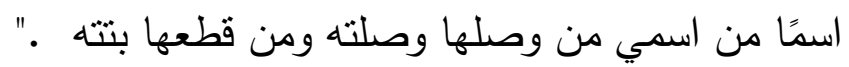

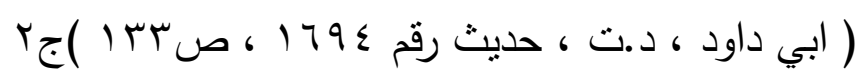

وإذًا فالرحم مشنقة من اسم الله الرحمن ، وقد وعد سبحانه وتعالى من وصلها أن

يصله وصلته سبحانه من محبته ، كما توعد من قطعها بقطعه وهو سبحانه وتعالى لا لا يقطع إلا من يبغضه ، فصلة الرحم تعود على فاعلها بالخير في المال والعمر ففي

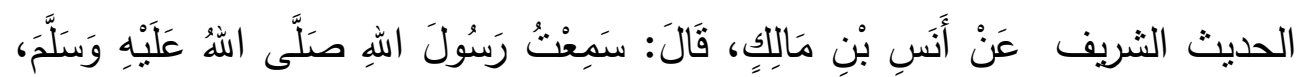

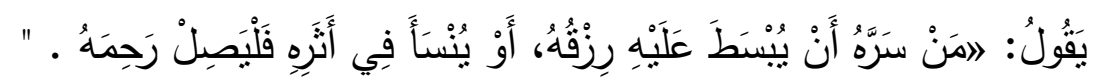

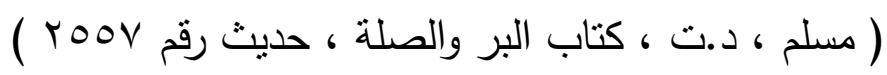

ومما ذكره ابن مفلح في هذا الثأن " والأم أولى بالبر ، وفي ذلك وصلة الرحم

أحاديث كثيرة ، وذكر ابن عبد البر الخبر عن النبي صلى اله عليه وسلم : " من أراد

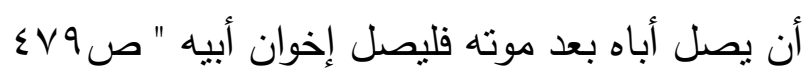
وبتضح مما سبق ، مما أورده ابن مفلح من مضامين تربوية اجتماعية في كتابه اليه الآداب الثرعية والمنح المرعية في علاقة الفرد المسلم بوالديه ، أن الوالدان في الأسرة لهما مكانة كبيرة ، أما عن مكانة الأم في الأسرة المسلمة ، فهي مكانة عظيمة أوصىى لإديه بها الله تعالى في آياته الكريمة ، كما أوصى بها رسول الله صلى الله عليه وسلم في أحاديثه المنتوعة للمسلمين المؤمنين ، ولقد كان من أهم تعاليم الإسلام بر الوالدين

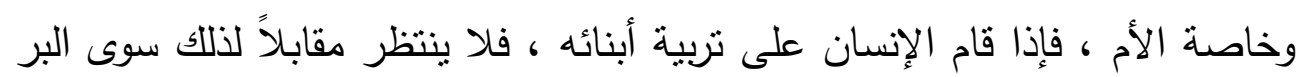
والإحسان في الثيخوخة حينما يجف عوده ، وينحني ظهره ، لا أن يرسل الأبناء 
بالآباء إلى منازل المسنين ، أو يجافوهم ، وإنما يصلونهم ويبرونهم ويسألون الله لهم الرحمة والمغفرة وبطيعونهم في غير معصية لله سبحانه وتعالى ، لذلك كان من أهم نقاط تتظيم الأسرة في الإسلام بمفهومها الواسع ، أن يعيش الإنسان داخلها في أمان منذ ولادته - وقبل ذلك حينما يختار الإنسان لنطفه - وحتى يصل إلى آخر مراحل الثيخوخة ، حتى يلقى الاحترام والتقدير والبر من أبنائه وأحفاده .

\section{المطلب الثاني :- ما المضامين التريوية الاجتماعية المتعلقة بعلاقة}

\section{• القرد المسلم بسائر المسلمين}

تتضمن علاقة الفرد المسلم بسائر المسلمين مجموعة من العلاقات من أهمها :-

\section{ا ـ موالاة المسلمين ونصحهم وإرشادهم :-}

فموالاة المؤمنين تتضمن حبهم لما هم عليه من الحق والهدى والتقى ، والبراء من أعداء الله يستلزم بغضهم وبغض ما هم فيه من الكفر ، فالحب والبغض هُه هما ترجمة الولاء والبراء في الواقع ، وهما أقوى وأوثق روابط الإيمان ، عَنْ عَبِّْ اللَّهِ

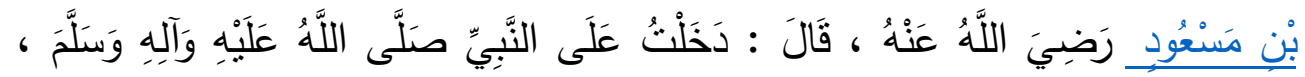

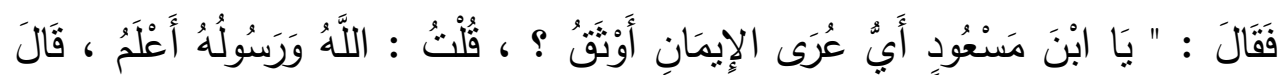

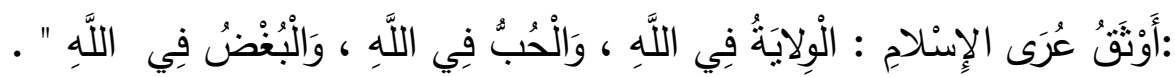

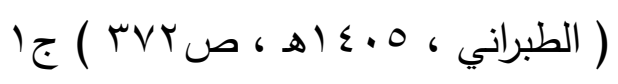

ومما ذكره ابن مفلح في كتابه الآداب الثرعية الجزء الثالث في هذا الثأن قوله " وذكر ابن عبد البر ، عن ابن عباس أنه قال : أحب في الله ، وأبغض في الله ، فإنه لا تتال ولاية الله الا بذلك ،ولن يجد عبد طعم الإيمان وإن كثرت صلاته وصومه حتى يكون كذلك " ص ابه وله

وقد حقق الصحابة ولاءهم للمؤمنين ، وتبرؤهم من المشركين في العديد من المواقف منها حين قطعوا علائق التتاصر والولاء الجاهلي ، وأحلوا محله الولاء 
الاسلامي ، والوقوف في صفه ، بإعلانهم في بيعة العقبة الكبرى مفاصلتهم الكفر وأهله ونصرتهم الله ورسوله والمؤمنين •

هذا الولاء وتلاك النصرة لله ورسوله هي التي دفعت الصحابة رضوان الله عليه

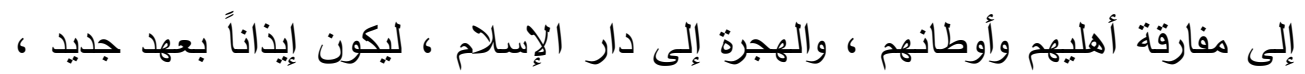

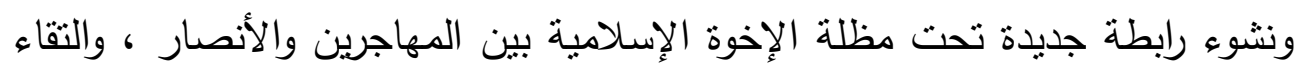
قلوبهم على محبة الله ورسوله يقول الله سبحانه وتعالى في محكم كتابه $\}$ إنَّ الَّذِينَ

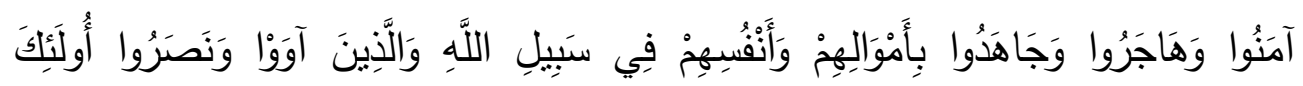

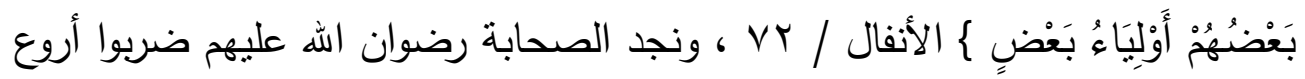

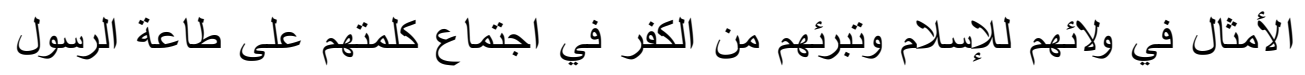

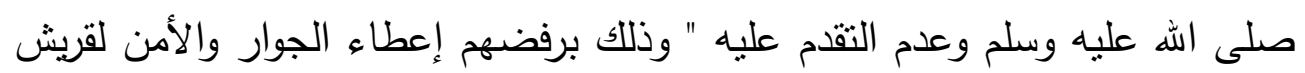
من عند انفسهم ، بل كانت مقولتهم : بل جوارنا في جوار رسول الله ، مثار عجب واندهاش عند أبي سفيان ، حين رأى هذا التلاحم والاتفاق من الجميع على اتباع الرسول صلى الله عليه وسلم فقال لقومه : وقد يئس من آخذ الأمان :) جئنكم من من مانم عند قوم قلوبهم على قلب واحد ، والله ما نركت منهم صغيرا ولا كبيرا ولا انتى ولا ذكر "إلا كلمته ، فلم انجح منهم شيئًا .

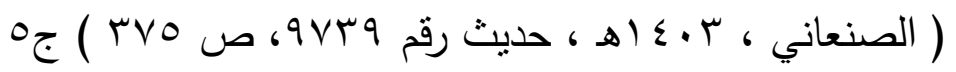

وأمّا النصيحة للمسلمين فهي الإخلاص في الإرشاد أو في التعامل معهم ، فإذا وزنا سلوك الإنسان مع ربه ومع أخيه المؤمن نجد أن هذا الإخلاص في فعله وقوله

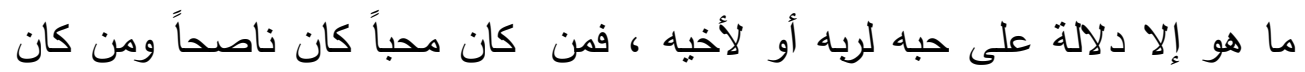
ناصحاً كان محباً ، وتكون النصيحة لعامة المسلمين من خلال مؤازرتهم وإرشادهم ومعاشرتهم بالمعروف والاهتمام بأمرهم والدفاع عن مظلومهم وهذا ما ارشد إليه

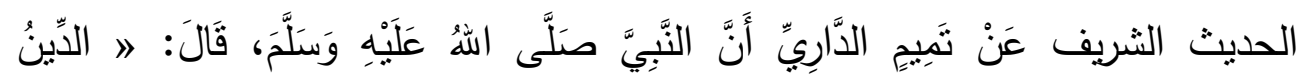




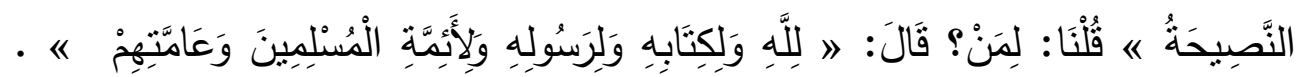

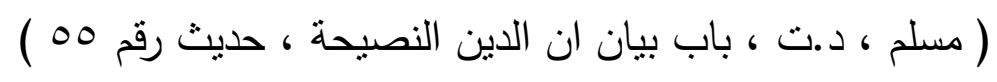

والنصيحة لها مكان عظيم في المجتمع وتقوية لحمته وجمع شمله ليكون مجتمعا ربانياً ، وذلك من خلال تقديم النصيحة وفق شروطها وضوابطها ومقوماتها وذللك حتى يتحقق الهدف من النصيحة وهو التغيير والإصلاح والنطوير لا التنفير والتكدير ومما ذكره ابن مفلح في كتابه الآداب الثرعية الجزء الأول في هذا الثأن قوله " على هوتى المؤمن موالاة المؤمنين والنصيحة لهم " ص • بـ؛ وقوله " روى مسلم عن ابي هريرة ((حق المسلم على المسلم ست )) وفيه إذا استتصحكَ فانصحْ له ، وهذا أولى له

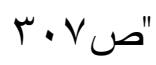

أي على المؤمن ان يحرص على موالاة المؤمنين والنصح لهم لما فيه من أثز عظيم في بناء المجتمع وتقويته وجعله على قلب رجل واحد ، فيكون بذلك جسداً قوياً يتجه الى هدف واحد لتحقيقه أي أنهم : مجتمعون يدا واحدة على غيرهم من أرباب الملل والأديان ، فلا يسع أحدا منهم أن يتقاعد عن نصرة أخيه المسلم . وقد شبه الرسول صلى الله عليه وسلم المسلمين في تآزرهم بالبناء الواحد يقوي

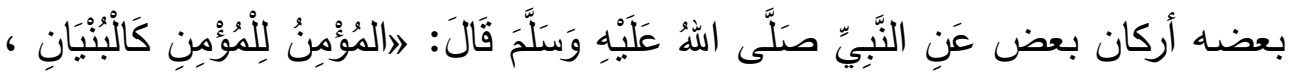

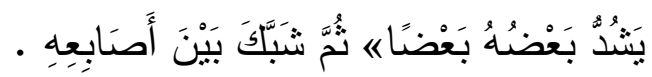

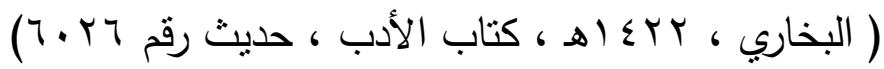

كما شبهرم بالجسد الواحد الذي يتشارك جميع أعضائه في الإحساس بالألم

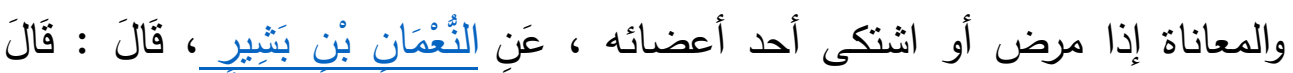

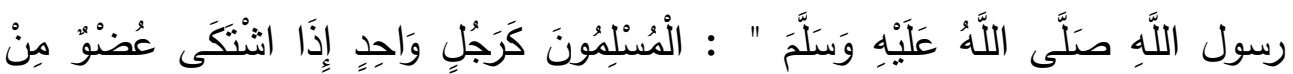

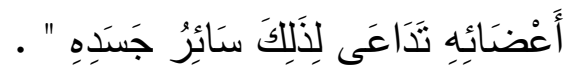

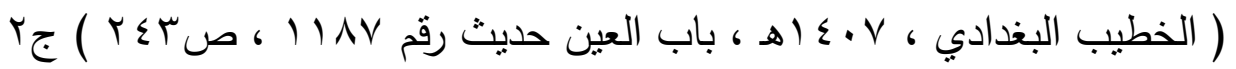




\section{Y.شكر الناس وصنع الخير لهم :-}

من أروع فنون العلاقات الإنسانية أن تُقَّمّ الثكر لمن أسدى إليك معروفًا ، فالذي يساعد الناس يبذل جهذًا لذلك ، وقد يفعل هذا الجهد في مرَّة ، ويفتر عنه في مرَّات أخرى ، وتقديم الشكر له يساعده على استمرار بذل الجهد في هذا المجال ، وليس في انتظاره للشكر شيء ؛ لأن الفطرة الإنسانية مجبولة على ذلك ، وقد علَّنَا رسول الله صلى الله عليه وسلم أن نشكر الناس عندما يفعلون خيرًا لنا ، فقد روى

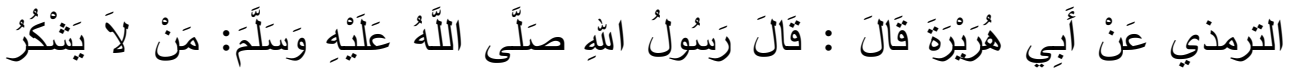

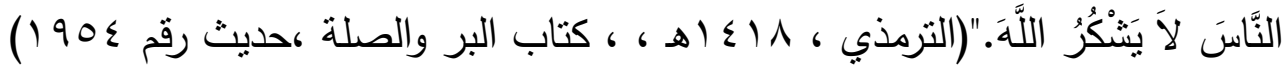
بل وعلَّمنا كيفية هذا الثكر وطريقته ، عَنِ ابْن عُعَرَ ، قَالَ : قَالَ رَسُولُ اللَّهِ

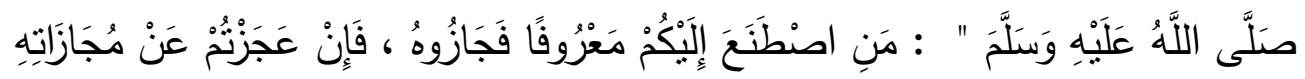

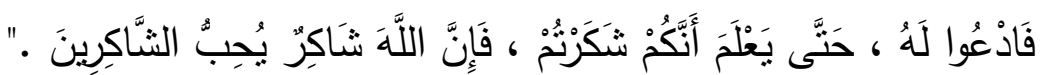

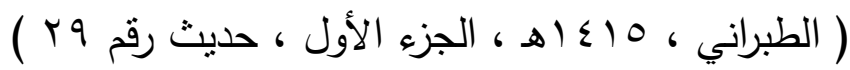

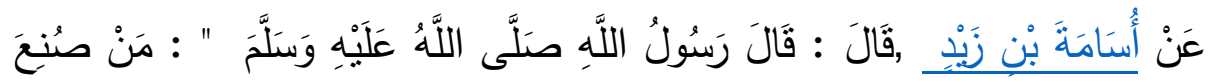

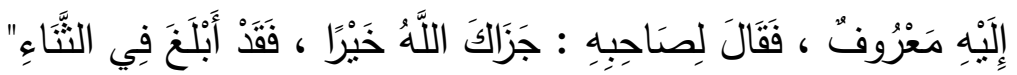

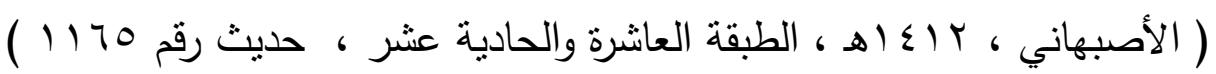
فلنحرص على شكر الناس ، ولنحفظ هذا الدعاء النبوي الجميل : "جزالك الله قال القاضي : وهذا إما لأن شكره تعالى إنما يتم بمطاوعته وامتتال أمره وأن مما أمر به شكر الناس الذين هم وسائط في إيصال نعم الله إليه ، فمن لم يطاوعه فيه لم يكن

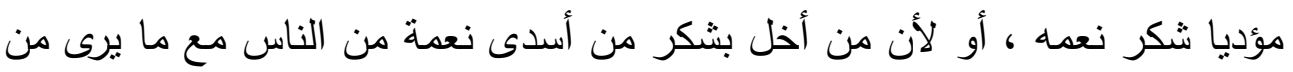
حرصه على حب الثناء والثنكر على النعماء وتأذيه بالإعراض والكفران كان أولى بأن يتهاون في شكر من بستوي عنده الثكر والكفران ، ولو علم الثيطان أن طريقاً

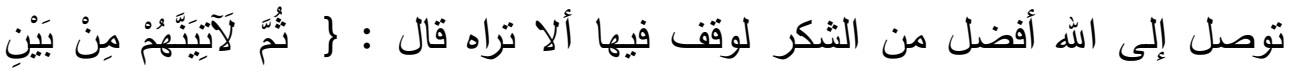




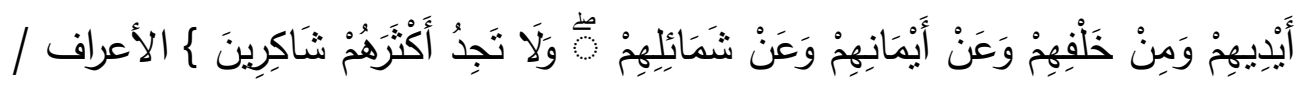
V ، ولم يقل لا تجد أكثرهم صابرين أو نحوه ، ويكون الثكر لمن فوقلك بالطاعة ولنظيرك بالمكافأة ، ولمن دونك بالإحسان والإفضال .

ومما ذكره ابن مفلح في كتابه الآداب الثرعية الجزء الأول في هذا الثأن قوله " معناه أن الله تعالى لا يقبل شكر العبد على إحسانه إليه إذا كان العبد لا يشكر الإديه

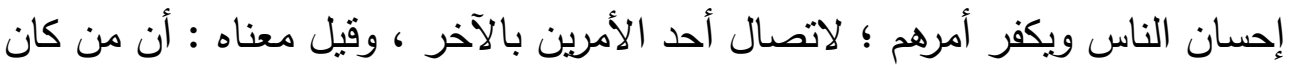
عادته وطبعه كفران نعمة الناس وترك شكره لهم كان من عادته كفر نعمة الله عز وجل وترك الثكر له ، وقيل معناه أن من لا يشكر الناس كان كمن لا يشكر الله عز وجل وأن شكره كما تقول لا يحبني من لا يحبك أي : أن محبتلك مقرونة بمحبتي فمن وند

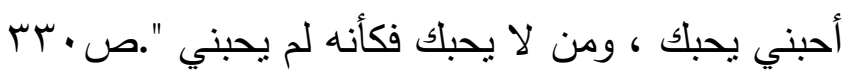

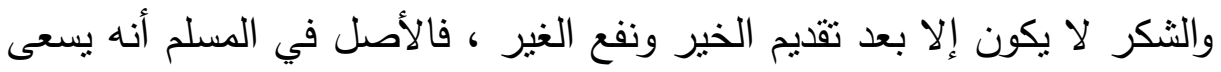
إلى تقديم الخدمة لمن يحتاجها ، والنصيحة لمن يجهاها ، والمنفعة إلى من هو أهل لها ، بمبادرة منه وحرص من طرفه ، ورسولنا صلى الله عليه وسلم كان يسعى إلى إلى

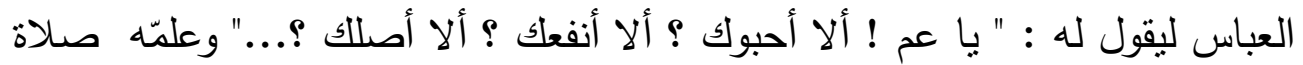
التسبيح ، وهكذا كان يعرض نفسه للنفع ، ويعلم الناس النفع ، وكان من وصية رسول الله صلى الله عليه وسلم لأبي برزة عندما طلب منه ان يعلمه عمل يدخله الجنة

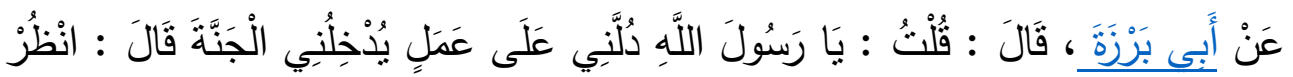

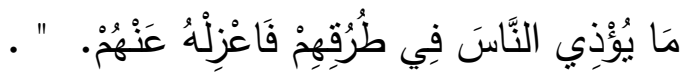

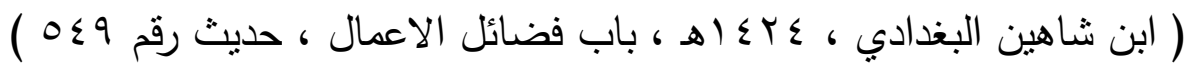
وعمل الخير ونفع الآخرين مطلوب وواجب بثكل عام لجميع المسلمين وله اجر عظيم ، كما أنه مطلوب على وجه خاص وأكثر وجوبا وأعظم أجرا للأقربين ـ قال أبو قلابة : وأي رجل أعظم أجرا من رجل ينفق على عيال صغار؛ يُعفّهم أو ينفعهم الله به ، ويعينهم الله به ويغنيهم !" وهذا الاهنمام بالأقارب كسب لقلوبهم ، وصلة رحم ، 
ورمز و فاء ، وعنوان محبة ، ودليل رحمة ، خاصة حين يكون فيهم أطفال صغار ،

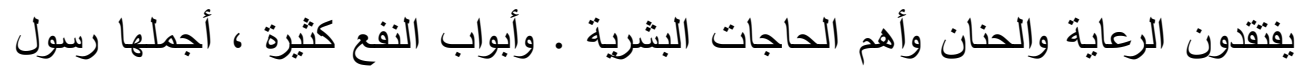

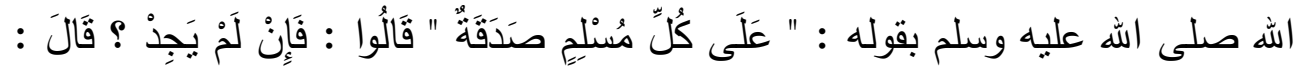

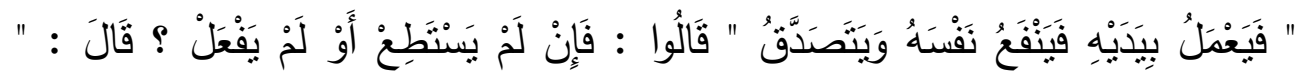

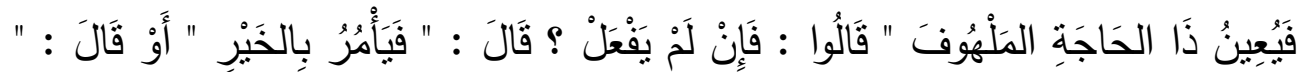

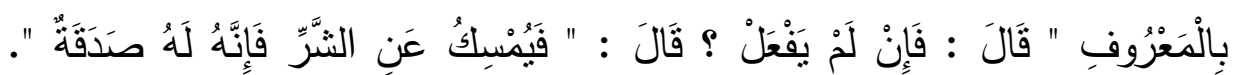

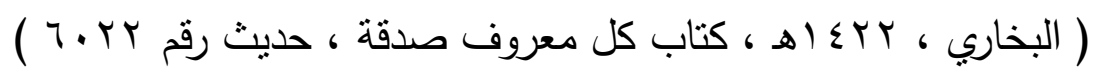

ومما ذكره ابن مفلح في كتابه الآداب الثرعية الجزء الأول في هذا الثأن قوله " وقال زيد بن علي بن حسين : ما شيء أفضل من المعروف إلا ثوابه ، وليس كل من يرغب فيه يقدر عليه ، ولا كل من قدر عليه يؤذن له فيه ، فإذا اجتمعت الرغبة والقدرة والإذن تمت السعادة للطالب والمطلوب منه ، وكان يقال :اصنع المعروف إلى كل أحد ، فإن كان من أهله فقد وضعته في موضعه ، وإن لم يكن من أهله كنت

$$
\begin{aligned}
& \text { أنت من أهله ." ص كץ" هن }
\end{aligned}
$$

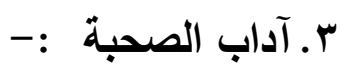

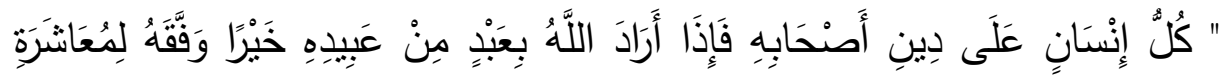

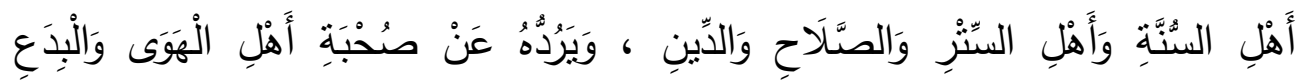

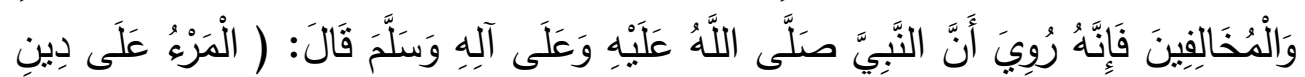

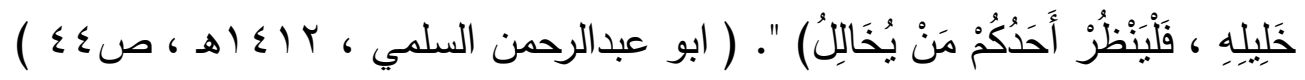
وعرف الجرجاني الأدب بأنه " عبارة عن معرفة ما يُحترز به عن جميع أنواع

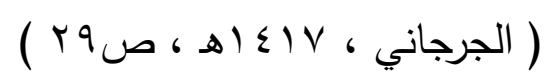

فقل لي من أصدقاؤك أقل للك من أنت ، فإنلك كصديقلك ؛ طبعلك يسرق من طبعه ، وسيرتك تتنسب إلى سيرته ، وأخلاقك تستقي من أخلاقة ، فمجالسة الحريص 
تحرك الحرص ، ومجالسة الزاهد تعلم الزهد في الدنيا ، وذلك لأن الطباع جُبلت على التشبه والاقتداء .

ومما ذكره ابن مفلح في كتابه الآداب الثرعية الجزء الثاني في هذا الثأن قوله "

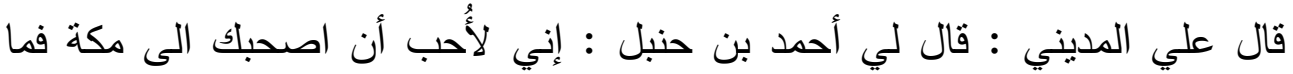

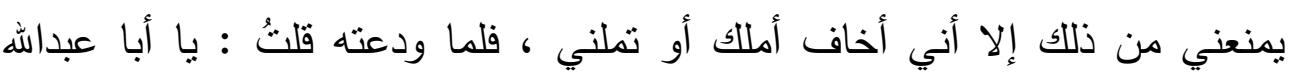
توُصيني بشيءٍ ؟ قال : نعم ، ألزم التقوى قلبك ، وأجعل الآخرة أمامك . وروى الخلال في الأدب عن مكحول قال : قلت للحسن : إني أريدُ أن أخرج إلى مكة ، قال : فلا تصحب رجلاً يكرم عليك ، فينقطع الذي بينك وبينه ، عن مجاهد قال : قلت لصديقٍ لي من قريش : تعال أوأضعك الرأي ؛ فانظر أين رأيي من رأيك ؟ فقال لي : دع المودة على حالها ، قال : فغلبني القرشي بعقله ." ص •9 19 19 ومما سبق نستخلص أن يكون فيمن تؤثز صحبته مجموعة من الخصال : منها

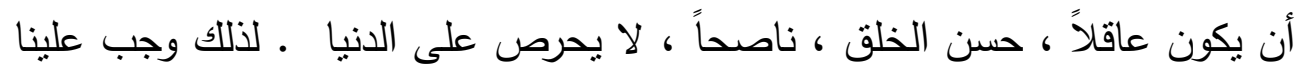
كمسلمين الحرص على الصحبة الصالحة ، الصحبة النقيَّة ، الصحبة الخالصة لله تعالى - فقد كان النبي - صلى الله عليه وسلم - يُوصي أُمَّته عَنْ أَبِي سَعِيدِ ، أَنَّهُ

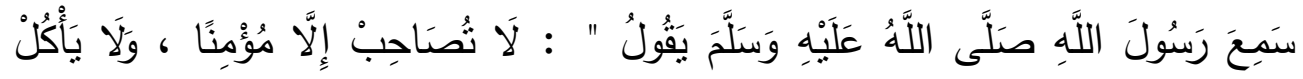

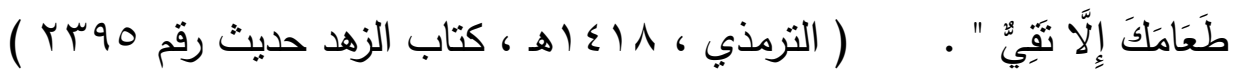
فأدب الصحبة من أعظم النعم التي يمتن بها الله تعالى على عباده ، فالإنسان في هذه الحياة لا بد أن يكون لله أصدقاء وإخوان ؛ لأن الإنسان اجتماعي بطبعه ، وأفضل طريقة لدوام الصحبة والمحافظة عليها هي الالتزام بآداب الصحبة ، والله سبحانه وتعالى قد أوصى النبي صلى الله عليه وسلم بأصحابه خيراً فقال الله عز

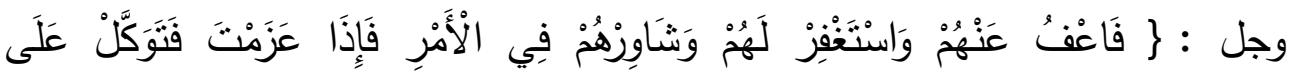

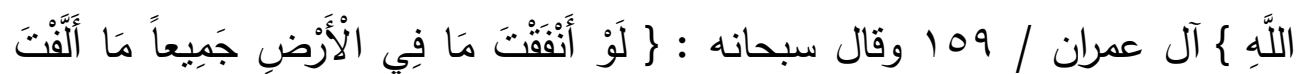

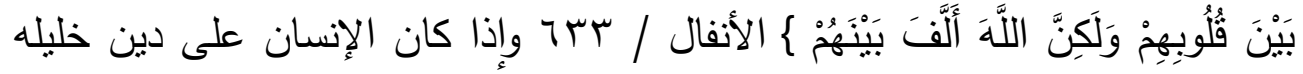


فلا بد أن يكون لهذا الخليل صفات تجعل مصاحبته في مرضاة الله سبحانه وتعالى ، والصاحب يؤثر في صاحبه لا شك ، فالاعتناء بآداب الصحبة بربط الإخوان

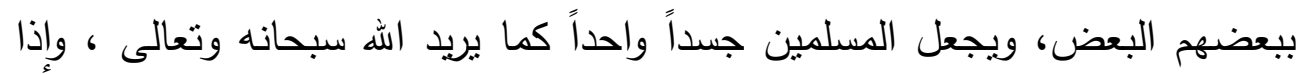

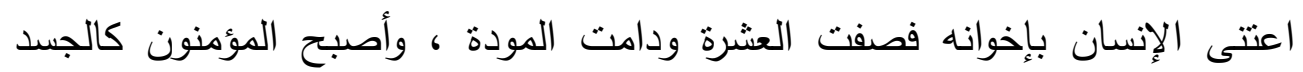

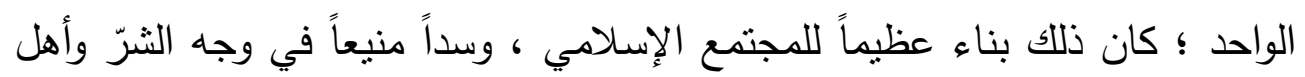

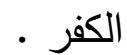

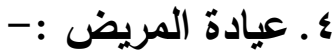

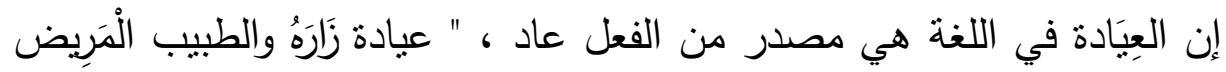

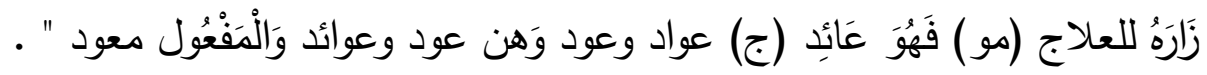

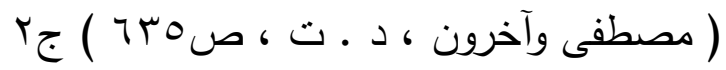

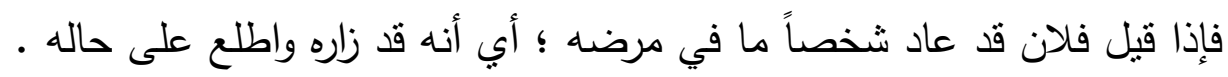

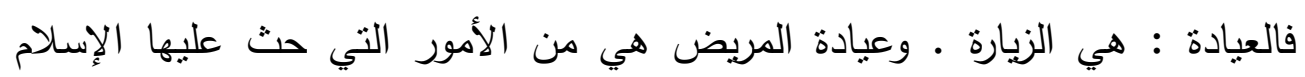

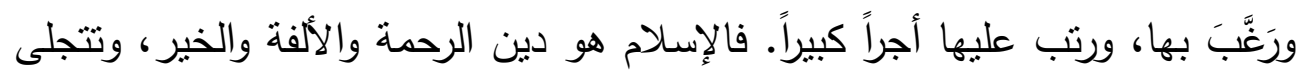
هذه الرحمة بالكثير من الأمور التي حث عليها هذا الإسلام العظيم ، والتي منها لهاليا

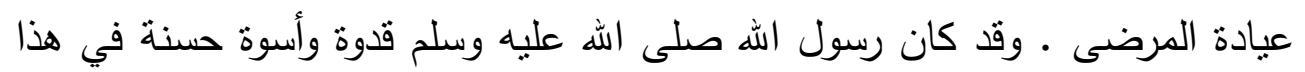

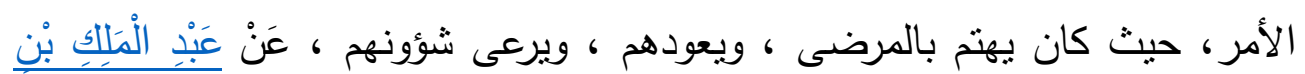

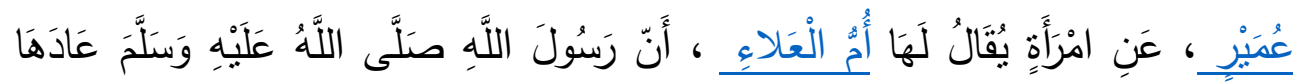

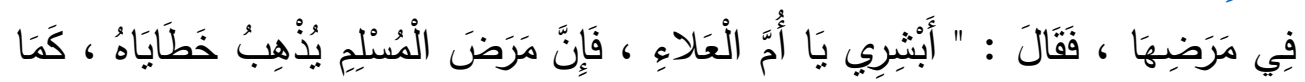

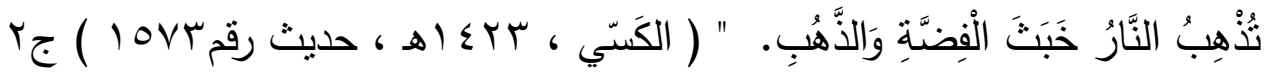

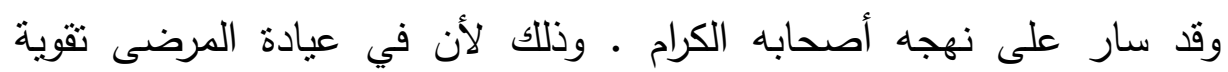
للعلاقات الإنسانية والإجتماعية في المجتمع الإنسامي ، فعيادة المريض تجلب

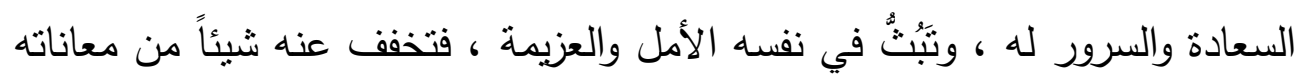


، وتكون عوناً له على الثفاء ، كما أن عيادة المريض تذكر العائد - إذا كان صحيح الجسم - بنعمة الله عليه بالعافية والصحة ، فيدفعه ذلك إلى شكر الله تعالى . وعيادة المريض هي من حق المسلم على المسلم ، حيث قال رسول الله صلى

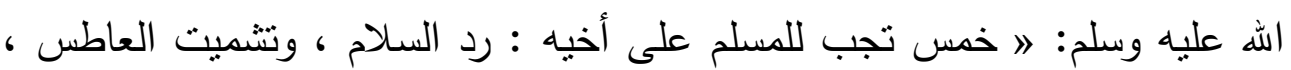
وإجابة الدعوة ، وعيادة المريض ، واتباع الجنائز • « •

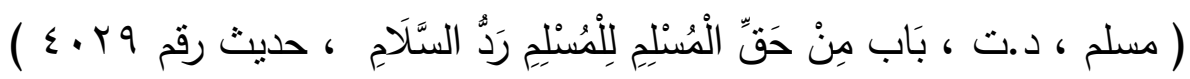
ولعيادة المريض الكثير من الفضائل التي جاء ذكرها في عددٍ من النصوص الشرعية ، ومنها : قوله صلى الله عليه وسلم في الحديث القدسي : (( عَنْ أَبي هَي

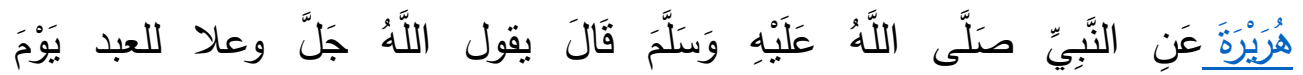

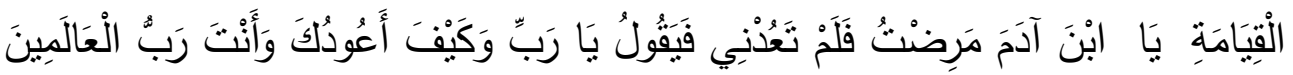

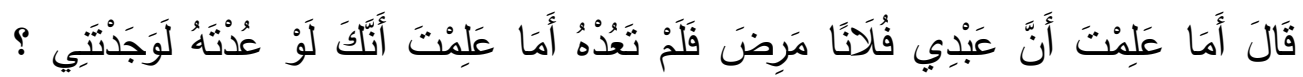

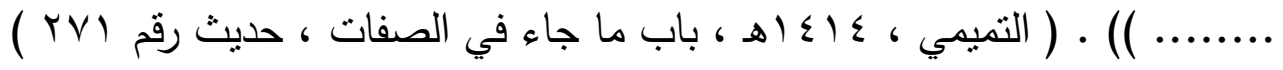
ومما ذكره ابن مفلح في كتابه الآداب الثرعية الجزء الثاني في هذا الثأن قوله " تُستحب عيادة المريض . قال بعض الأصحاب : وتكره وسط النهار ، نص عليه .

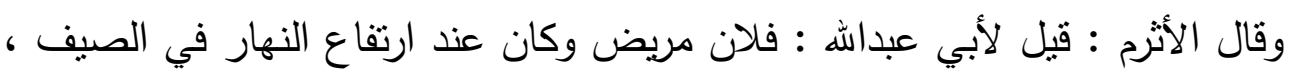
فقال : ليس هذا وقت عيادة ـ قال القاضي : وظاهر هذا كراهية العيادة في ذلك

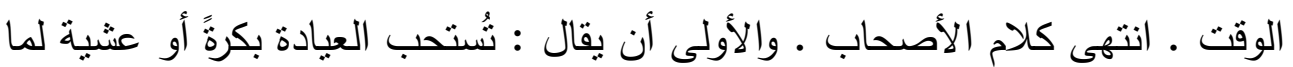
فيه من تكثير صلاة الملائكة ـ وقال المروذي : عُدتُ مع أبي عبداله مريضاً بالليل

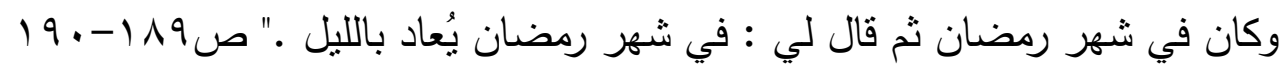

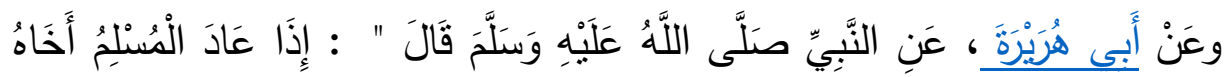

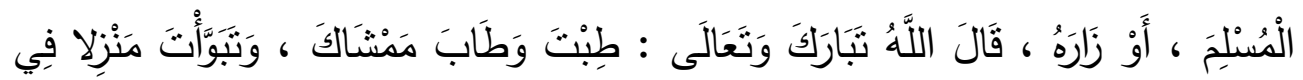

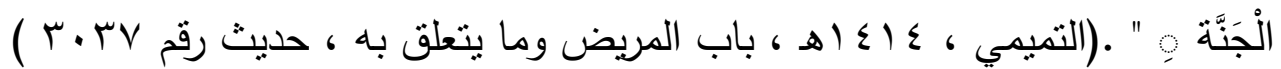


ومن آداب عيادة المريض: أن يختار العائد وقتاً مناسباً للزيارة ، ألا يمكث

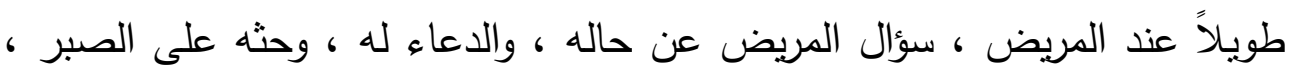
على ألا يزعجه بكثرة الكلام والثرثرة ، وطرح الأسئلة ، ألا يتكلم أمام المريض بأي شيءٍ قد يزعجه ، ويثبط من عزائمه .

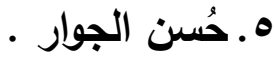

حُسنُ الجوار هو الإحسانُ إلى الأثخاص الذين يجاوروننا بالسكن ، وتجنّب إيذائهم ، والالنزام بأخلاق الإسلام في التعامل معهم ، وعدم إلحاق أب أذى بهم مهما صَغُر ، وعدم البغي عليهم أو ظلمهم ، واحترام حرمة بيوتهم ، والالتزام بحُسن

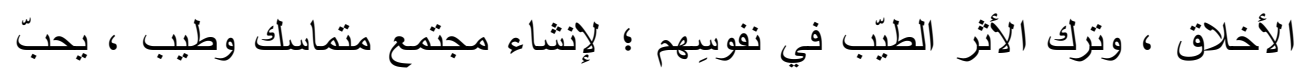

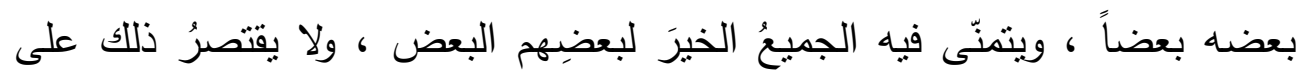

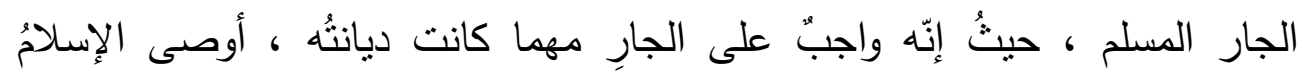
بالجار ، وأمرَ الله سبحانه وتعالى بالإحسان إليه وتجنّب إيذائه ، وقد جاء ذكر الجار في القرآن الكريم والسنّة النبوية الثريفة ، حيث يقولُ عزّ وجلّ: (وَاعْبُدُوا اللَّهَ وَلا

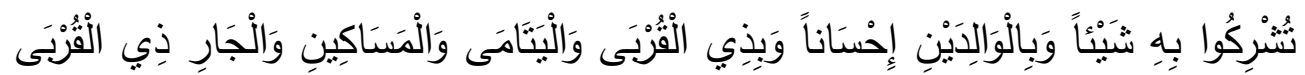

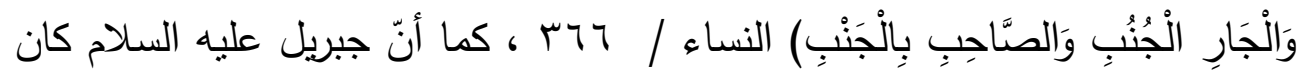

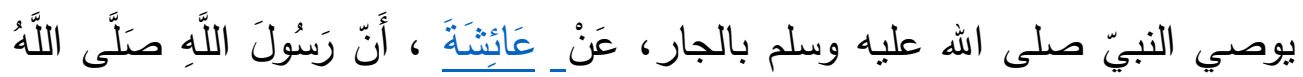

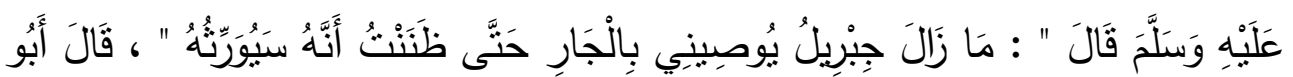

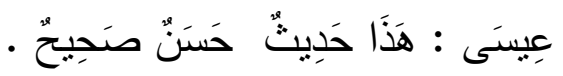

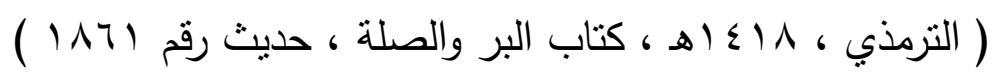

وهذا دليلٌ قاطعٌ على منزلة الجار في الإسلام ، وضرورة الإحسان إلبه ؛ لأنّ ، إن

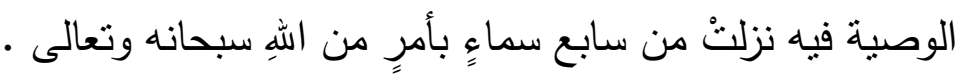




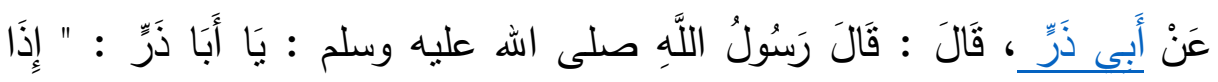

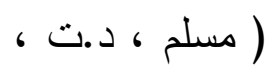

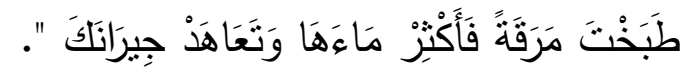

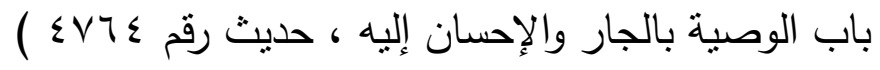

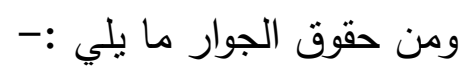

إلقاء السلام عليه ؛ لما في السلام من تقريب للقلوب ، وتثتيبٍٍ للمحبة والودّ ، وهو من الأخلاق الحميدة ، والصفات الرفيعة.

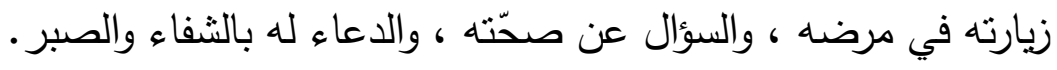

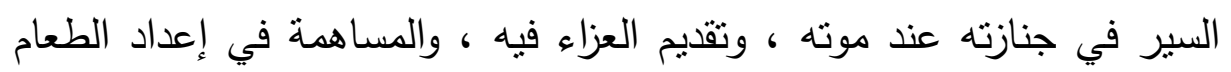

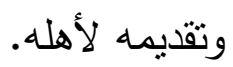

دعوته إلى المناسبات ، مثل : الأعراس ، وحفلات المولود وغيرها ، كذلك ثلبية

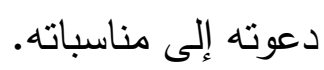

• سترُ عبوبه ، وعدم التكلم بها أمام الناس ، وحفظ عرضه . • أمره بالمعروف ونهيه عن المنكر .

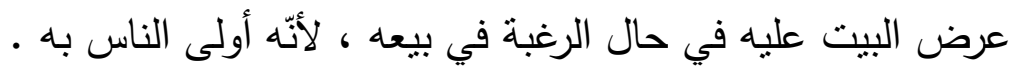
• تقديم النصيحة الصادقة له في كلّ وقت.

تعظيم حرماته ، وتجنّب غدره أو خيانته أو المكر له أو معاونة الهُ الآخرين عليه . عدم رمي القاذورات أمام بيته ، وإماطة الأذى عنده.

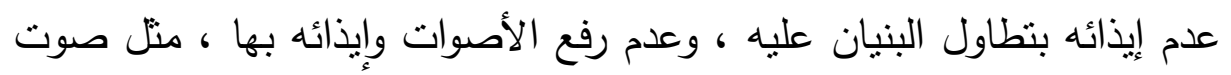

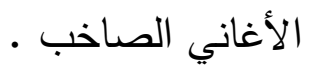
ت تفقده في كل وقت ، والاهتمام بقضاء حوائجه قدر الإمكان .

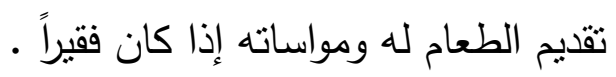

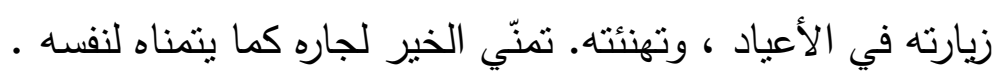

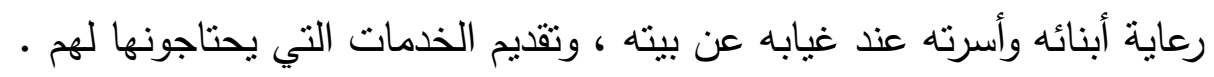


ومما ذكره ابن مفلح في كتابه الآداب الثرعية الجزء الثاني في هذا الثأن قوله " وروى المروذي عن الحسن : ليس حسن الجوار كف الأذى ، حسن الجوار الصبر على الأذى • ورواه أبو حفص العكبري في الأدب له عن الشعبي. وفي الصحيحين من حديث عائشة ومن حديث ابن عمر : " مازال جبريل يوصيني بالجار حتى ظنتت أنه سيورثه " ، وفيهما من حديث أبي هريرة : " من كان يؤمن بالهه واليوم الأخر فلا يؤذ جاره " ولمسلم : فليحسن إلى جاره " ولأحمد من حديث عبداله بن عمر " فليحفظ هي هرة

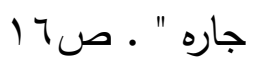
فالإسلام يقوم على جملة مرتكزات ترتقي بالفرد وتسمو بالمجتمع ، ومن أهمها: المبادئ الأخلاقية والقيَم الفاضلة التي تجعل من الأمة أسرة منرابطة ، ولكي تسلم العلاقات الاجتماعية ينبغي أن تقوم على الأسس التي دعا إليها القرآن الكريم فال

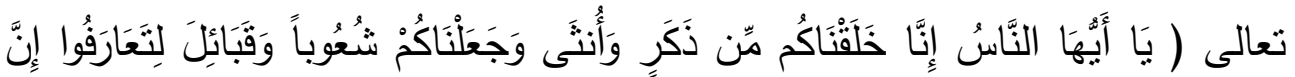

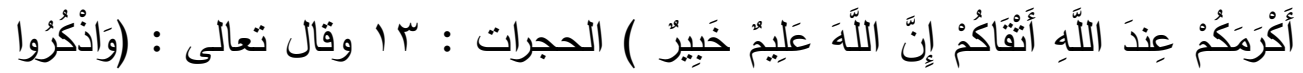

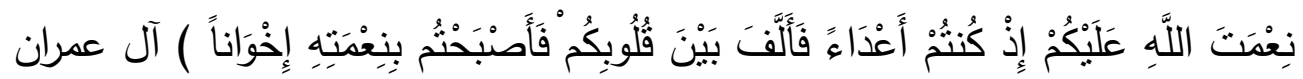

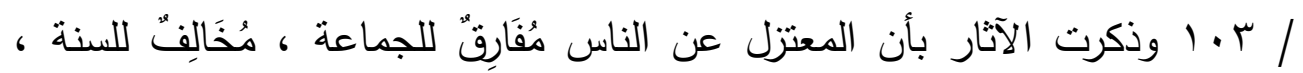
فالمرء قليل بنفسه كثير بإخوانه ، ولذا حرص الإسلام على عقد روح التعاون بين

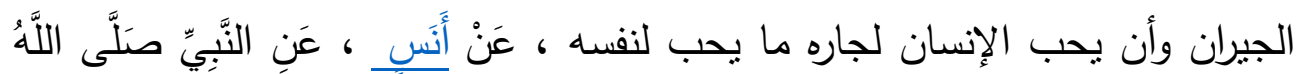

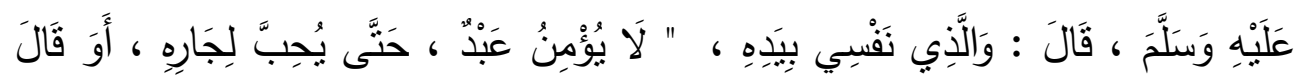
لِأَخِيهِ مَا يُحِبُُ لِنَفْسِهِ.

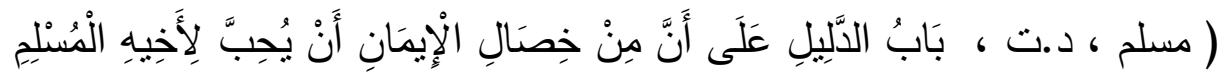

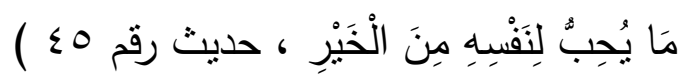

ويتضح مما سبق ، مما أورده ابن مفلح من مضامين تربوية اجتماعية في كتابه الآداب الثرعية والمنح المرعية في علاقة الفرد المسلم بسائر المسلمين ، أن المسلمين لا بد أن تكون قلوبهم متحدة في التوادّ والتحابّ والتعاطف بسبب ما جمعهم من أمر 
الدين وضمهم من الإيمان بالله ـ فنسبتهح بطريق القرابة الدينية المبنية على المعاقدة المستتبعة للآثار من المعونة والنصرة وغير ذللك ـ ومن الأدلة عَنِ ابْن عَبَّاسِ ، عَنِ

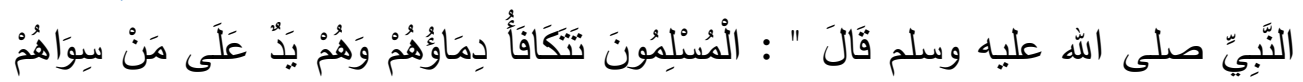

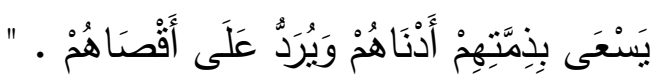

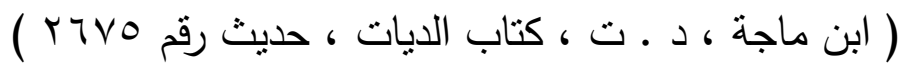

وفي هذا دليل على وحدة المسلمين وترابطهم ، وأنه لا بد أن يهتم المسلم بشأن إخوانه فهم كالجسد الواحد ولا يتصور أن يهمل الإنسان يده أو رجله أو أي عضو من وند أعضائه فيتركه ولا يتحس آلامه ، إلا إذا كان أنثل ميتاً ، وبقدر إيمان المؤمن تثقد فيه تلك الجذوة ويتحرك فيه ذلك الإحساس ، وقد قال النبي صلى الله عليه وسلم: () (1) لا يؤمن أحدكم حتى يحب لأخيه ما يحب لنفسه )) والخير كلمة جامعة تعم الطاعات

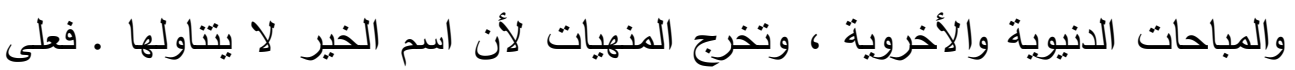
المسلم أن يهنم بأمر إخوانه ، ويسأل عن أخبارهم ، ويعين ضعيفهم ، وينصر

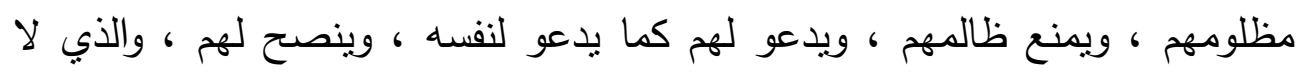

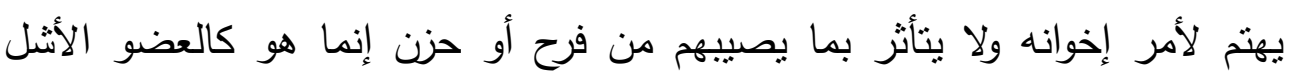

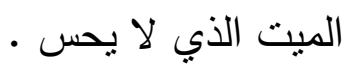

\section{المطلب الثالث :- ما المضامين التريوية الاجتماعية المتعلقة بعلاقة}

\section{• الفرد المسلم بأقاربيه}

تتضمن علاقة الفرد المسلم بأقاربه مجموعة من العلاقات التي تجسد التواصل الاجتماعي بين أفراد الرحم الواحد وما لها من فضل وثواب عند الله سبحانه وتعالى بلى بله

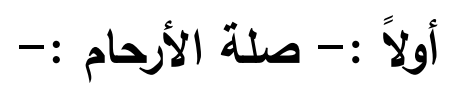

صلة الرحم من أهمّ الأعمال التي أمر الله تعالى بها عباده، ووعد الواصل بثواب عظيم، كما أعدّ للقاطع عقاباً شديداً، وقد بيّن لنا رسول الله صلى الله عليه وسلّم أنّ لهّ 
الواصل ليس فقط من أحسن لمن أحسن إليه ، إنّما الصلة الحقيقية تكون لمن أساء

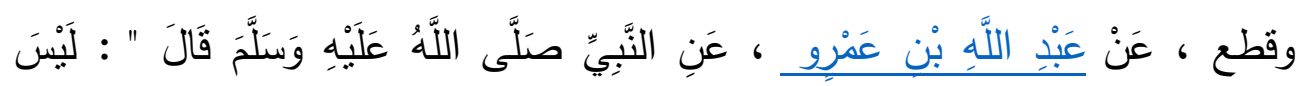

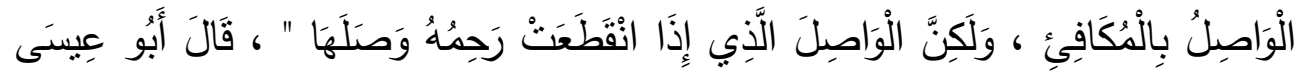

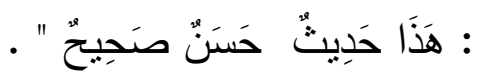

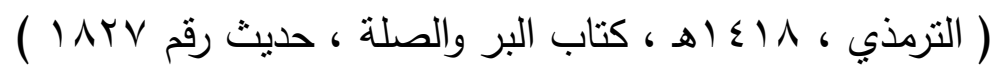

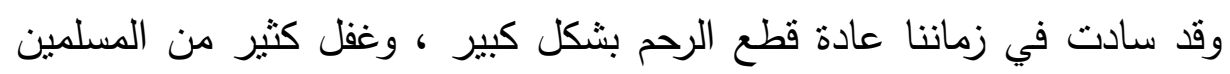

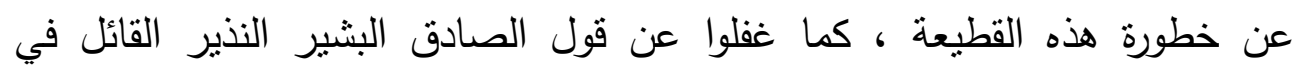
الحديث الذي رواه أبو هريرة رضي اله عنه : (( من كان بؤمن بالله واليوم الآخر

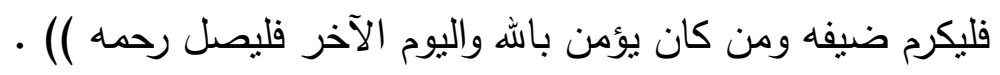

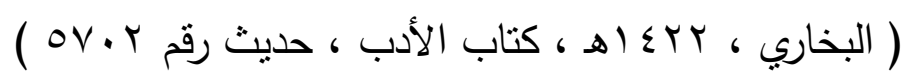

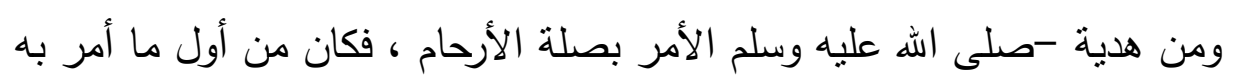

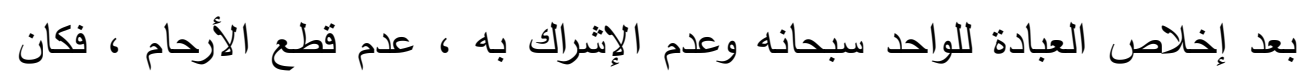

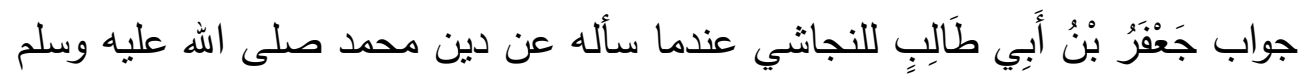

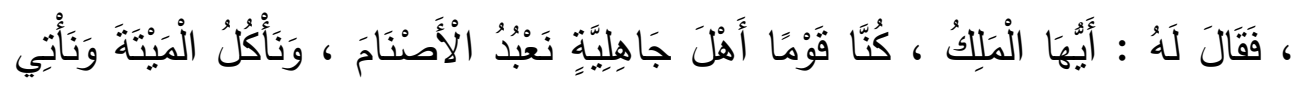

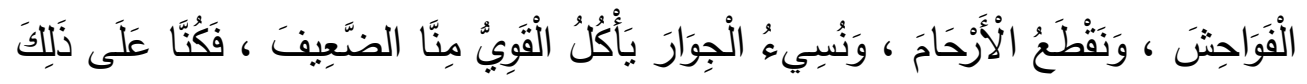

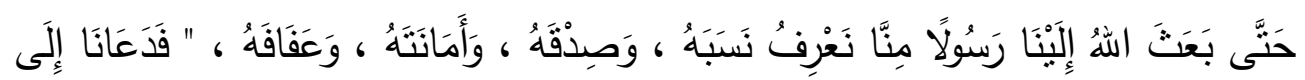

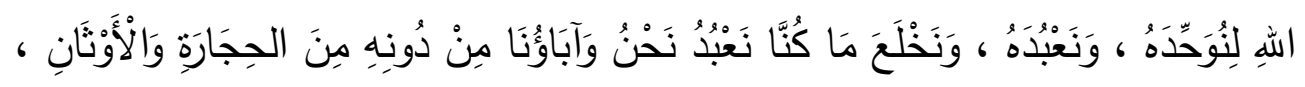

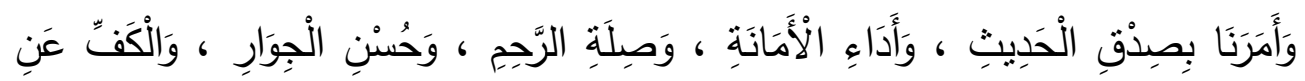

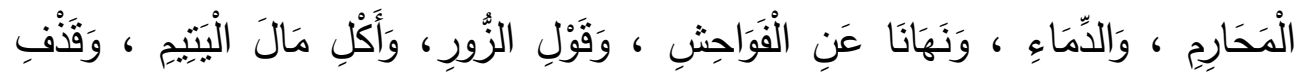

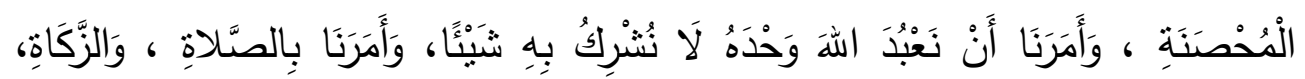

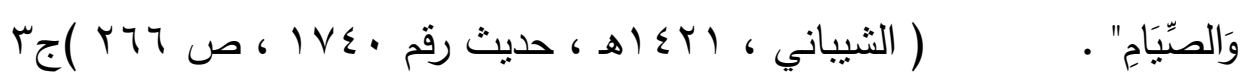




\section{I ـ تعريف صلة الأرحام :-}

هذا المصطلح مكون من شقين الثق الأول: الصلة، والثق الثاني : الأرحام أو الرحم ؛ ولذلك سنعرض لتعريف الصلة والرحم في اللغة . أ- الصلة في اللغة : وصل إلى بني فلان : انتمى إليهح وانتسب ، ووصل الثخص بين الطرفين ربط ووحد بينهما ، ووصل الثيء بالثيء ضدمَّه وجمعه ."

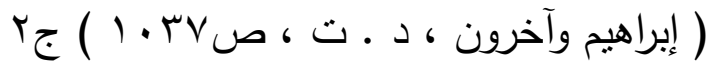

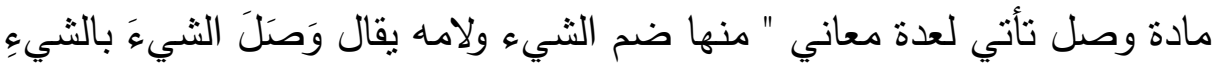

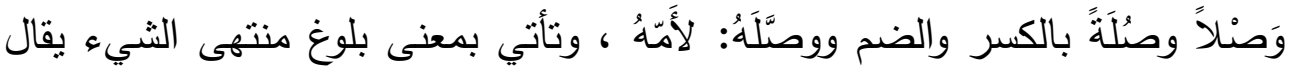

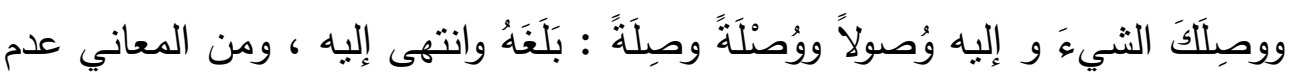

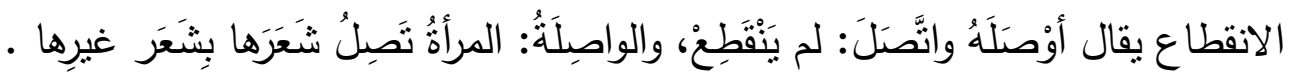

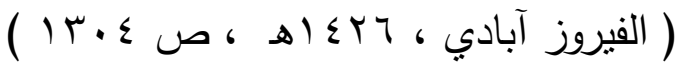

فصلة الأرحام هو التواصل معهم وعدم الانقطاع عنهم ، والإبقاء على هذه العلاقة متصلة .

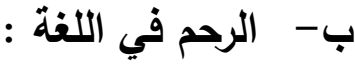

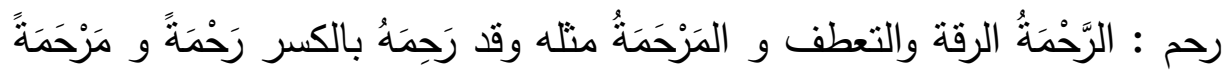

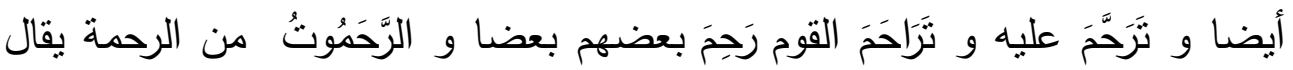

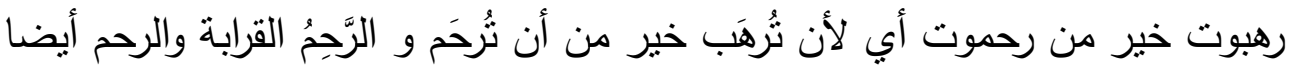
بوزن الجسم منتله و الرَّحْمنُ الرَّحِيٌُ اسمان مشتقان من الرحمة ونظيرهما نديم وندمان وهما بمعنى ويجوز تكرير الاسمين إذا اختلف اشتقاقهما على وجه التأكيد كما يقال فلان جاد مجد إلا أن الرحمن اسم مختص باله تعالى ولا يجوز أن يسمى به غيره ألا ترى أنه سبحانه وتعالى قال \} قل ادعوا الله أو ادعوا الرحمن \{ فعادل به الاسم الذي لهي لا يشركه فيه غيره وكان مسيلمة الكذاب يقال له رَحْمَانُ اليمامة و الرَّحِيُ قد يكون

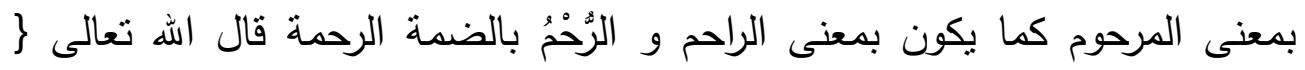


وأقرب رحما \{ و الرُحُمُ بضمنين منله ، والرحم : أحد أجزاء الجهاز التتاسلي الأنثوي

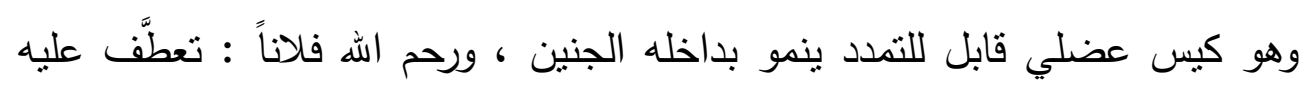

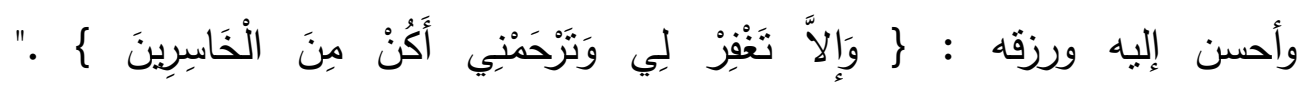

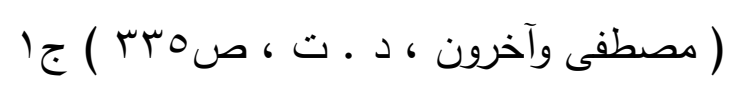

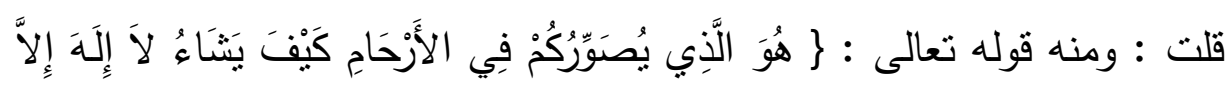

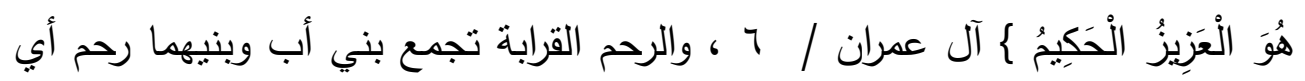

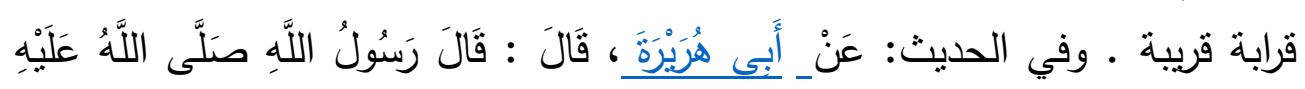

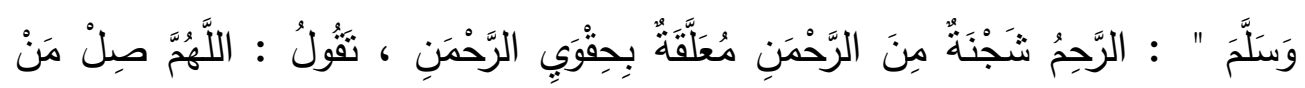

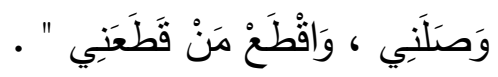

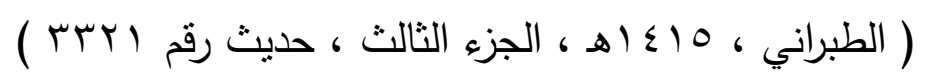
قال ابن الأثير: " ذو الرحم هم الأقارب ، ويطلق على كل من يجمع بينك وبينه

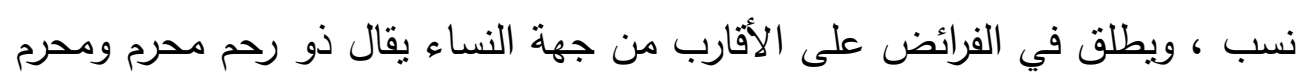
وهو من لا يحل نكاحه كالأم والبنت والأخت والعمة والخالة " .

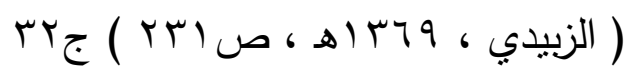

$$
\text { أ- الصلة في الاصطلاح : - }
$$

في الاصطلاح كما يفهم من المعنى اللغوي هي : الرحمة والتعطف والترحم

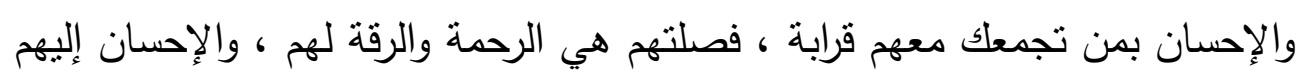

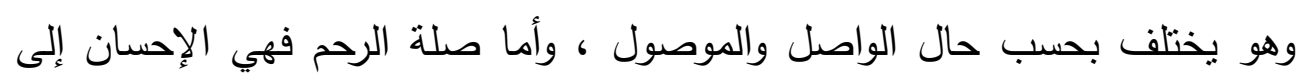

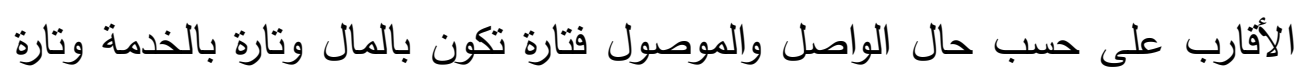

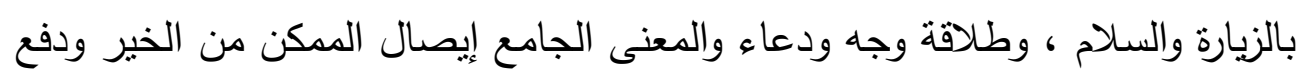

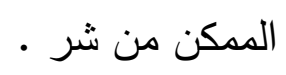


ب- الرحم في الاصطلاح :- اختلف أهل العلم في حد الرحم التي تجب صلتها

على قولين

فقيل : هو كل رحم محرم بحيث لو كان أحدهما ذكرا والأخر أنثى حرمت

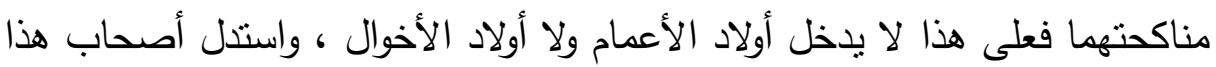

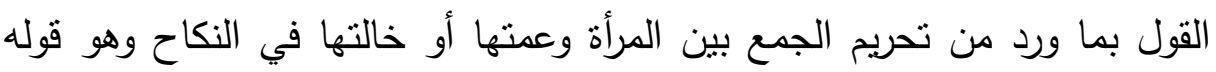
صلى الله عليه وسلم كما جاء في كتاب الآداب الثرعية لابن مفلح • والقول الثاني يرى بعضهم : بأنه عام في كل رحم من ذوي الأرحام في الميراث يستوي المحرم وغيره ، واستدل أصحاب هذا القول بقوله صلى الله عليه وسلم " ثم أدنالك أدنالك "

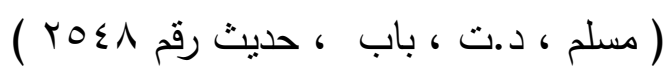

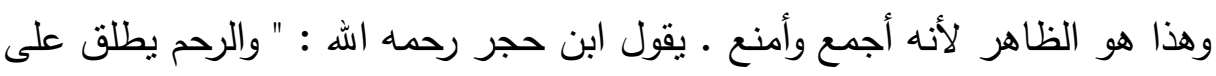

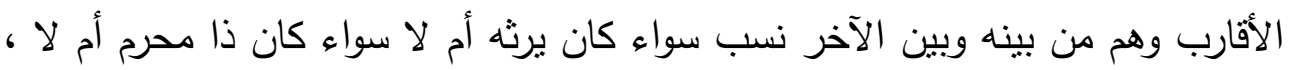

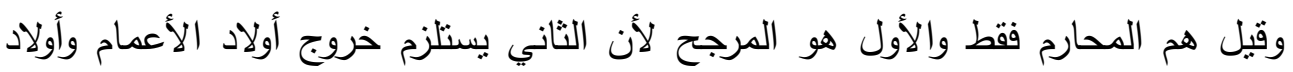

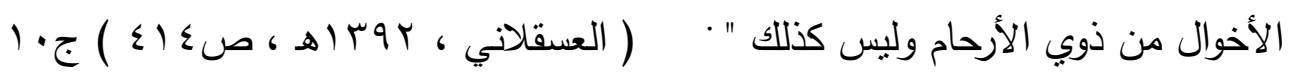
وخلاصة الأمر أن صلة الرحم كناية عن الإحسان إلى الأقربين من ذوي النسب

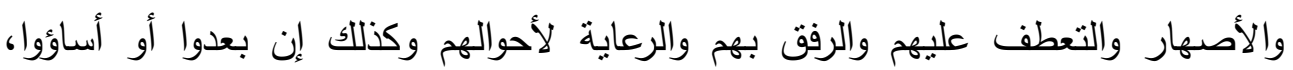
وقطع الرحم ضد ذلك كله يقال وصل رحمه يصلها وصلا وصلة والهاء فيها عوض من الواو المحذوفة فكانهه بالإحسان إليهم قد وصل ما بينه وبينهم من علاقة القرابة والصهر .

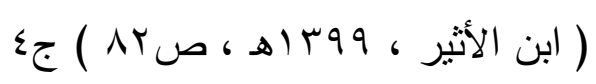

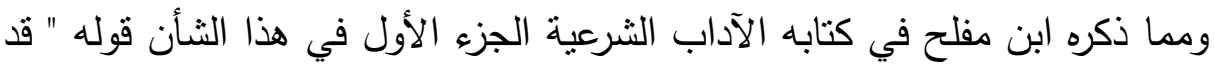

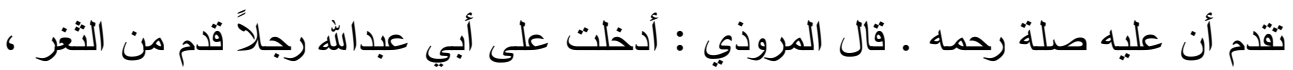
فقال : لي قرابة بالمراغة ، فترى لي أن أرجع إلى الثغر ، أو ترى أن أذهب فأسلم على إنى

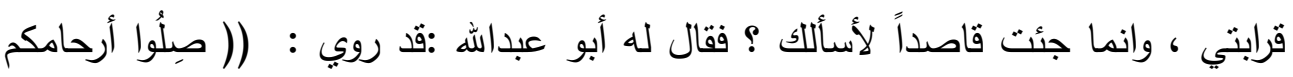
ولو بالسلام )) استخر اله ، واذهب فسلم عليهم • وقال مثتى : قلت لأبي عبداله : 
الرجل يكون لله القرابة من النساء ، فلا يقومون بين يديه ، فما يجي عليه من برّهم ، وفي كم ينبغي أن يأتيهم ؟ قال : اللطف والسلام • وقد ذكر أبو الخطاب وغيره في مسألة العتق بالملك : قد توعد الله سبحانه بقاطع الأرحام باللعن وإحباط العمل ، ومعلوم أن لن

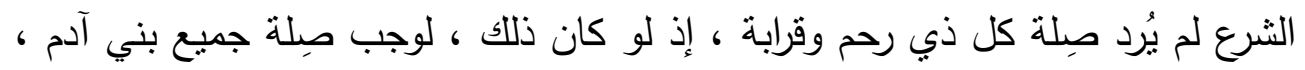
فلم يكن بُد من ضبط ذلك بقرابة تجب صلتها وإكرامها ويحرم قطعها ، وتلك قرابة الرحم المحرم • وقد نص عليه بقوله صلى الله عليه وسلم : (( لا تتكح المرأة على عمتها ، ولا

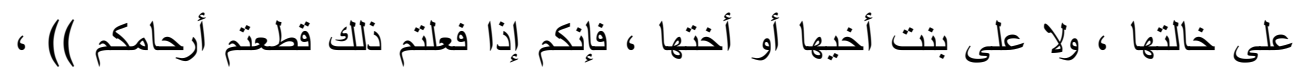

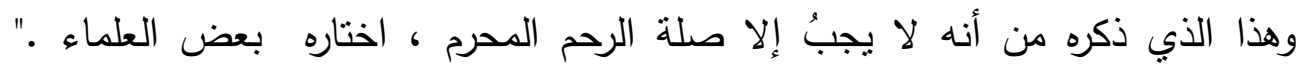
$\varepsilon \vee \wedge-\Sigma \vee \vee ص$

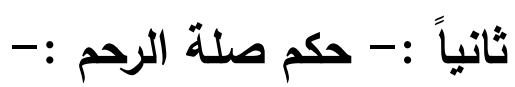
لا شك أن صلة الرحم واجبة بالجملة على المسلم ، وقطع صلة الأرحام من

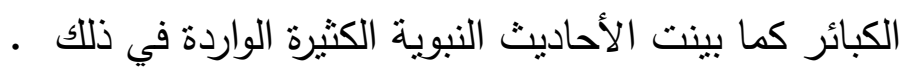
ثالثاً : - عظم إثم قاطع الرحم :ومما يدل على عظم صلة الرحم وتعظيم أمرها وأن صلتها مرغب فيه ، وأن

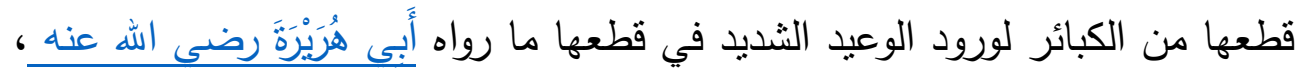

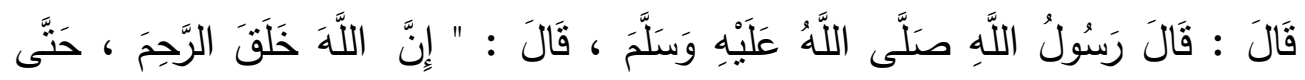

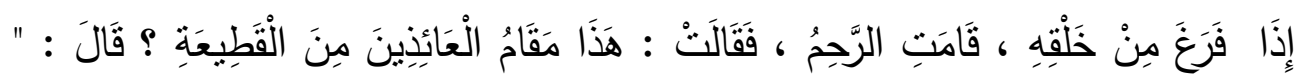

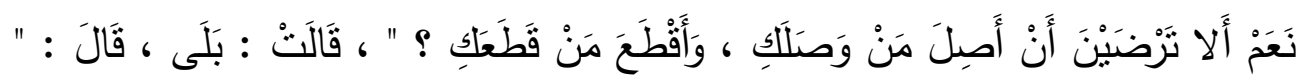

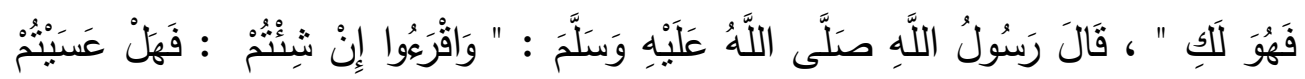

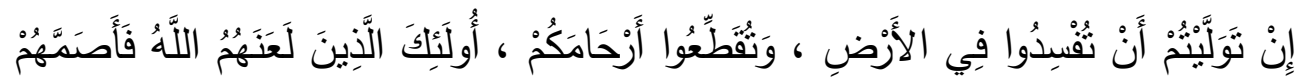

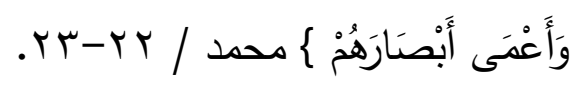

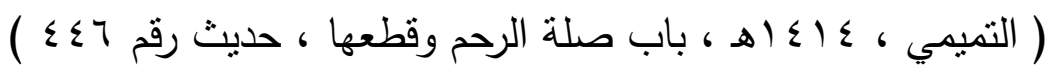




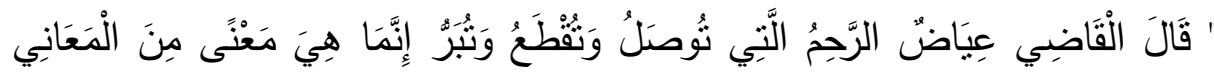

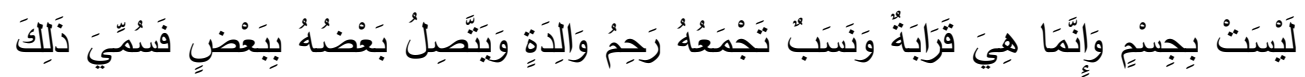

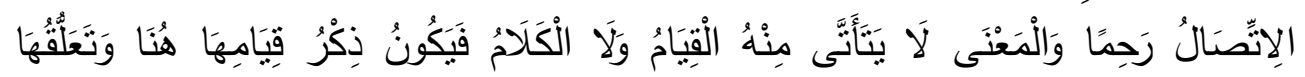

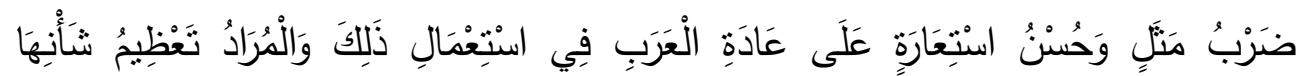

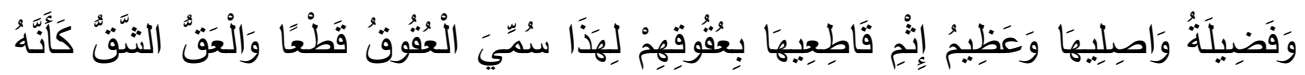

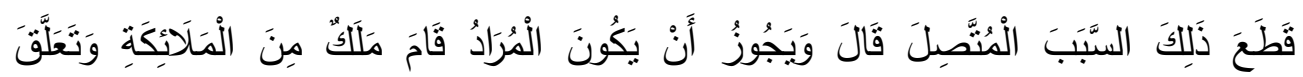

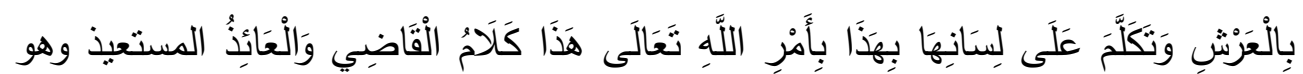

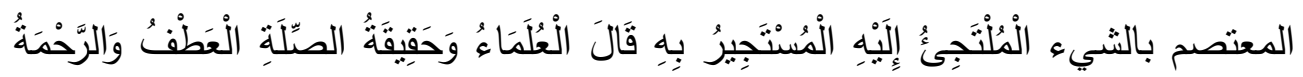

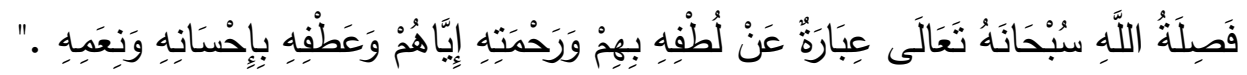

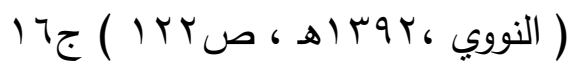
قد يكون هذا من باب ضرب المنل ، وقد يكون على الحقيقة والله على كل شيء قدير سبحانه.

والمقصود عظم أثم قطع الرحم يقول القرطبي : " وسواء قلنا إنه يعني القول المنسوب إلى الرحم على سبيل المجاز أو الحقيقة أو أنه على جهة التقدير والتمثيل كأن يكون المعنى لو كانت الرحم ممن يعقل ويتكلم لقالت كذا فمقصود هذا الكلام الإخبار بتأكد أمر صلة الرحم وأنه تعالى أنزلها منزلة من استجار به فأجاره فأدخله في حمايته

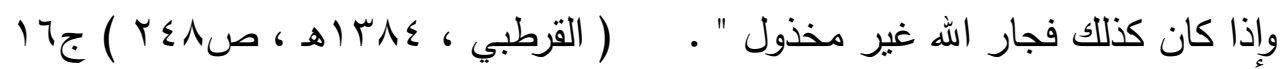
رابعاً :- صلة الرحم من أسباب البركة :أسباب حصول البركة كثيرة ، ولعل من أهم ما ورد به النص من حصول البركة في العمر أو الرزق أو غير ذلك صلة الأرحام ، فهي مما يكافئ الله عز وجل عليه الناس في الهم

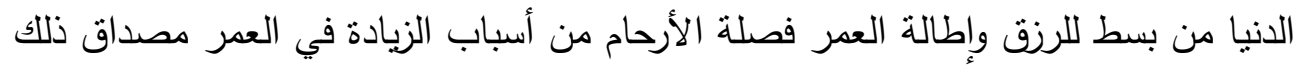

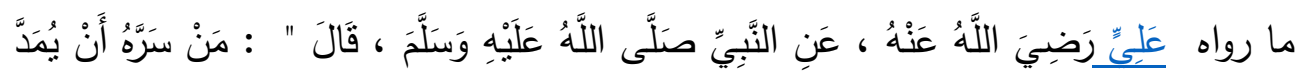

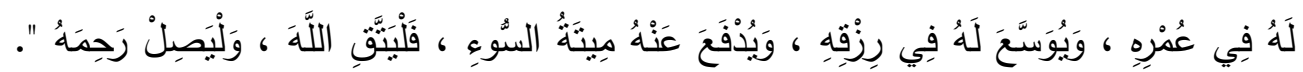

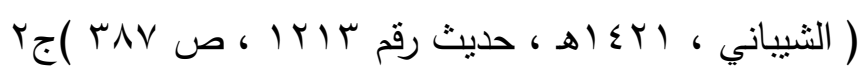




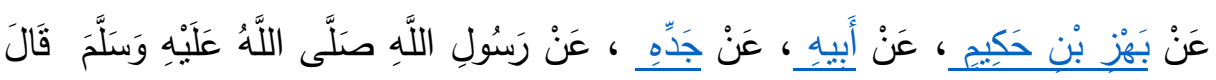

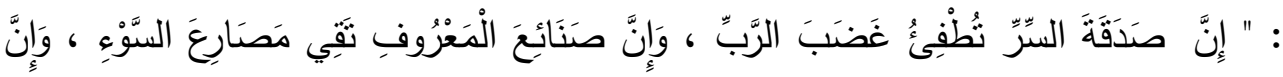

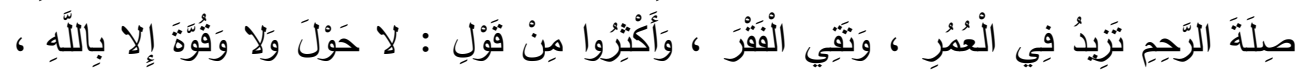

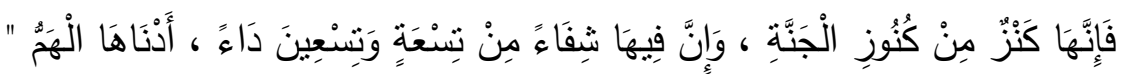

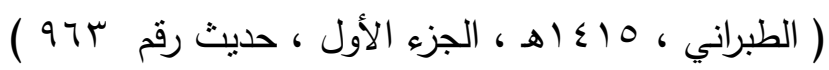

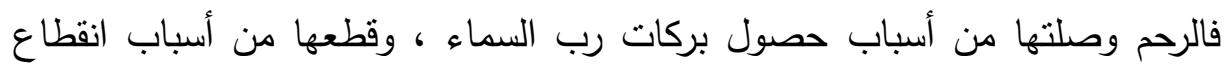
هذه البركات ، كما جاء في الأحاديث السابقة . .

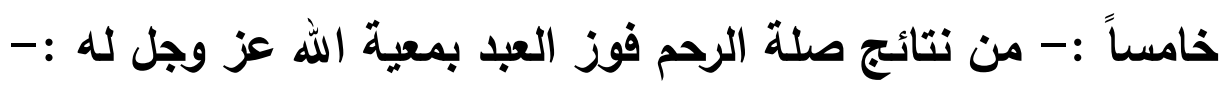

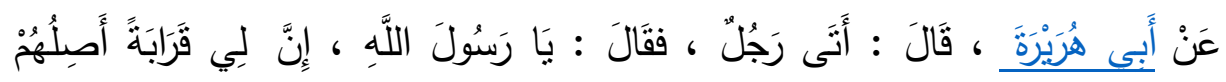

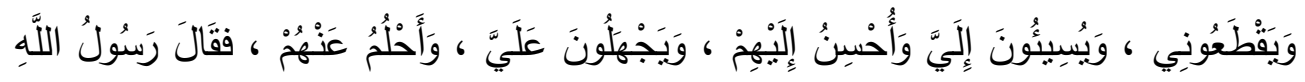

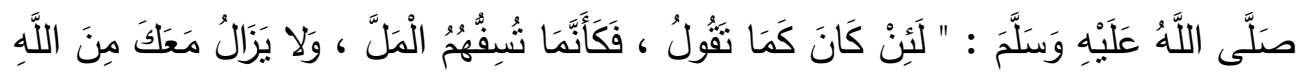

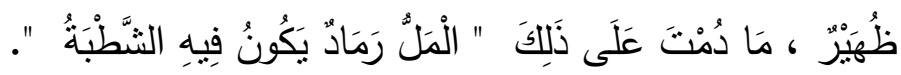

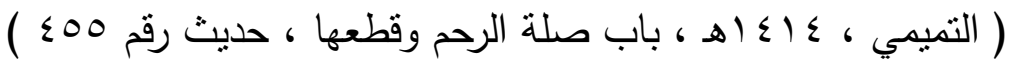
يقول الإمام النووي رحمه اله : " المل بفتح الميم الرماد الحار وتسفهم بضم التاء الثاء

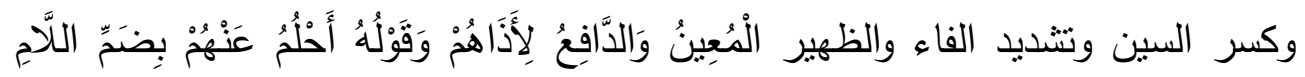

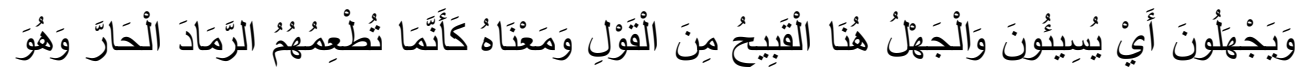

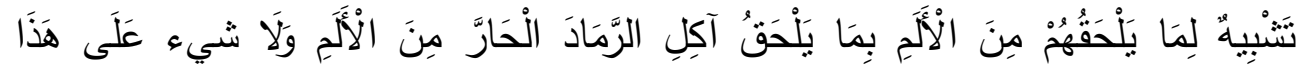

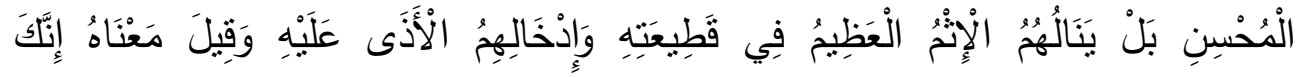

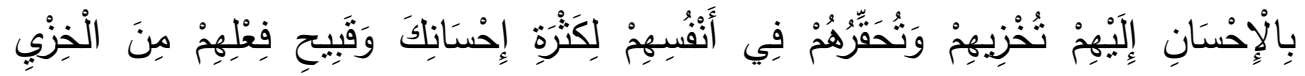

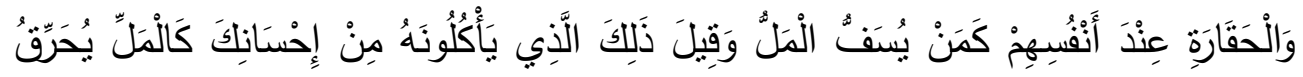

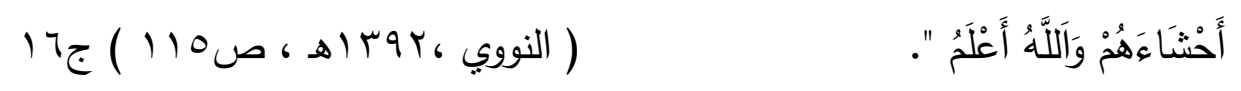

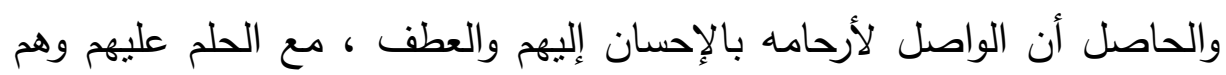
يقطعونه كان الله عز وجل معه يحفظه ويرعاه . 


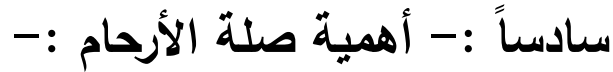

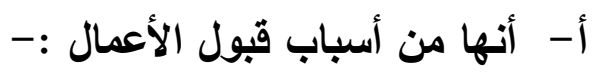

فصلة الأرحام والتواصل معهم ومساعدتهم وتفقد أحوالهم وإكرامهم من أهم أسباب الأبال

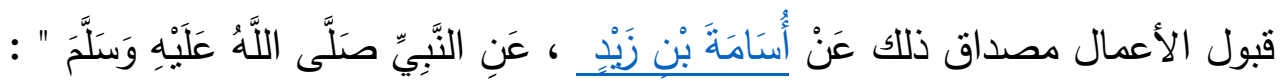

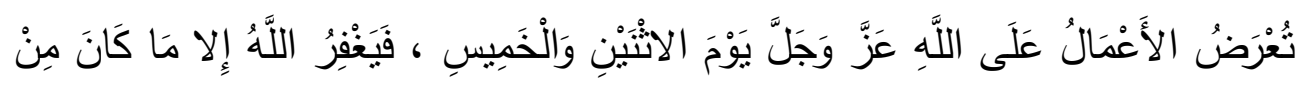

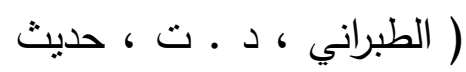

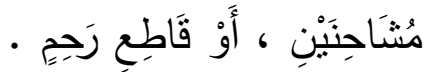

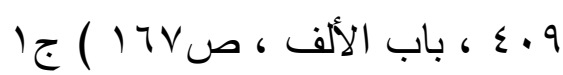

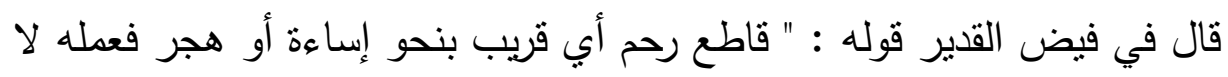

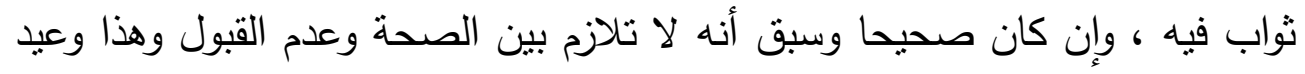

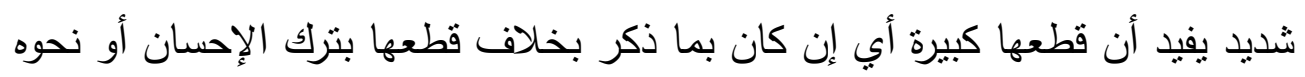

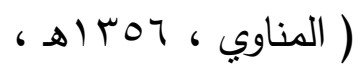
فليس بكبيرة بل ولا صغيرة."

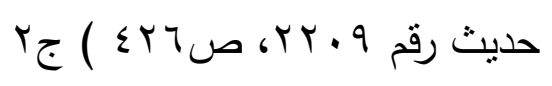

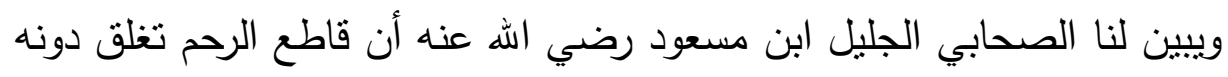

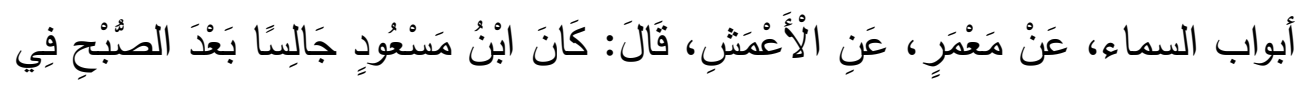

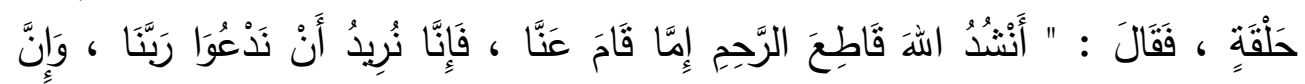

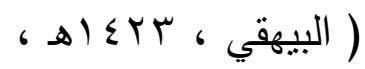

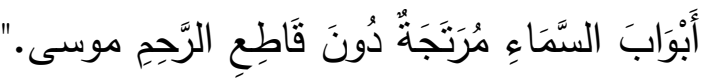

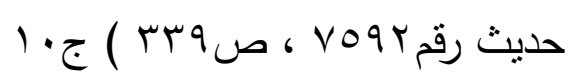

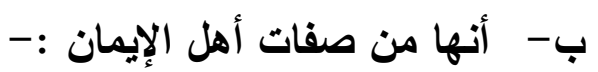

فقد وصف الله سبحانه وتعالى أهل الإيمان أهل الجنة بأنهم يصلون ما أمر اله

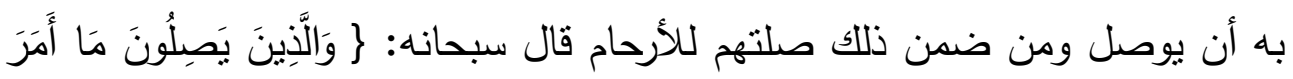

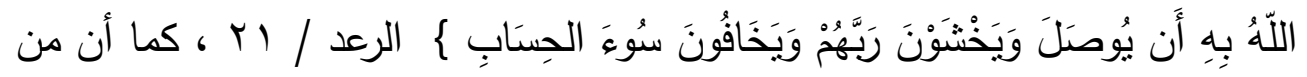

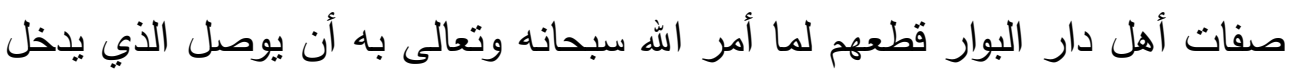

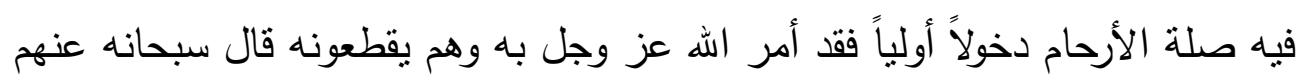




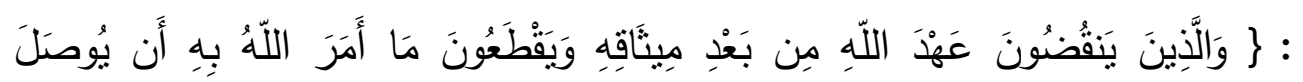

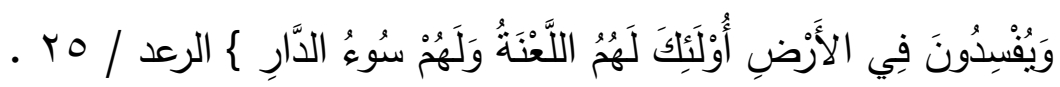

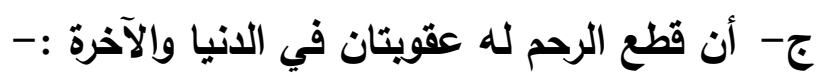

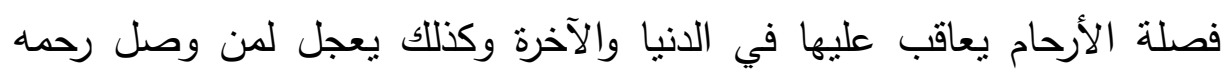

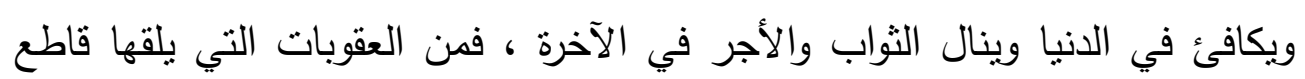

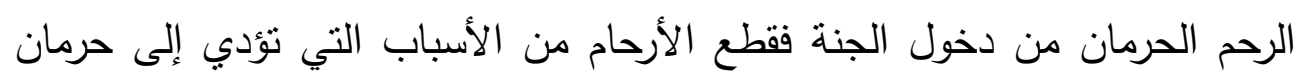

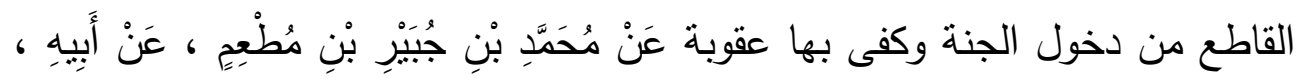

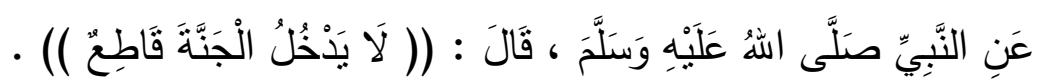

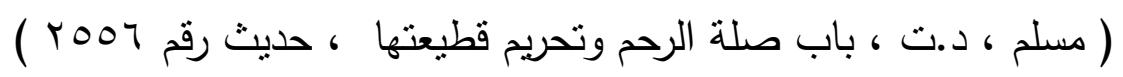

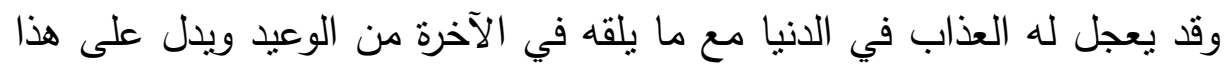

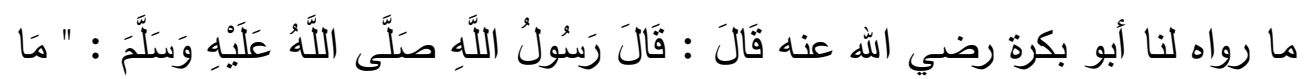

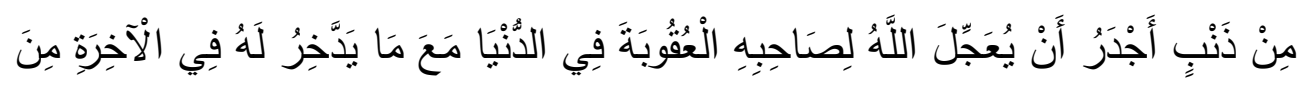

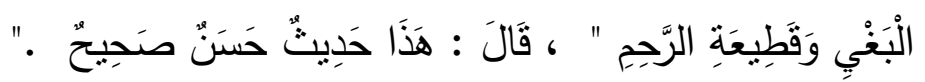

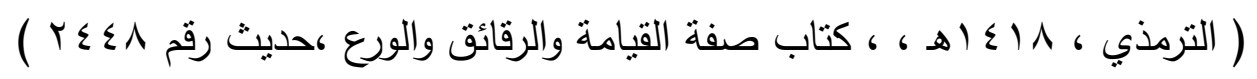

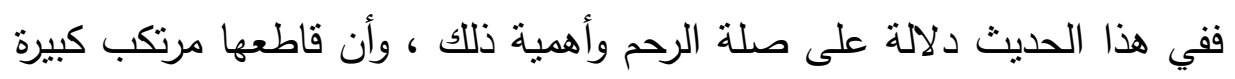
لورود الوعبد الثديد في ذلك فالوعيد حاصل له في الانيا والآخرة.

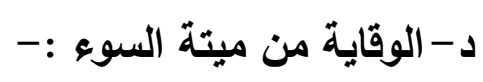

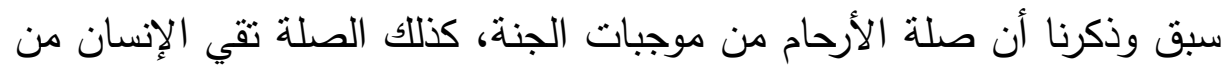

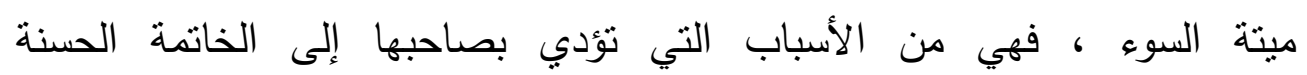

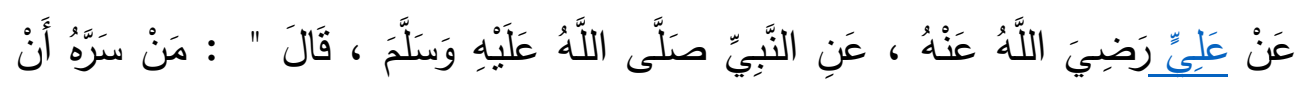

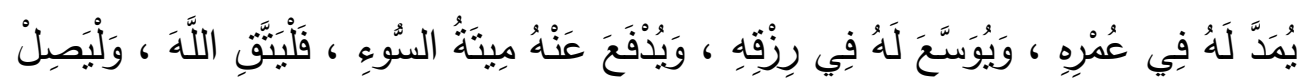

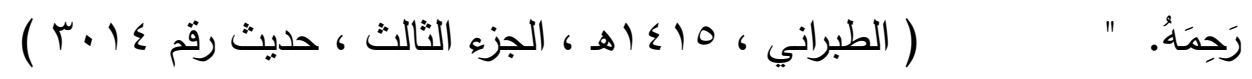




\section{هـ - صلة الرحم مطلوية ولو كان الموصول غير مسلم :-}

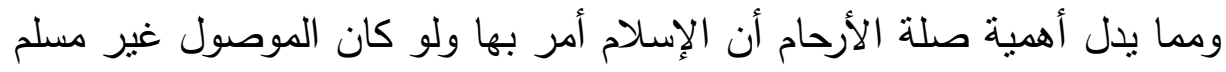
بحيث لا تتعارض مع الإسلام وأحكامه ، أو مصالح المسلمين ، فقد تكون من أسباب الإسل

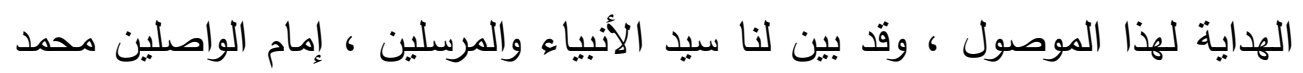

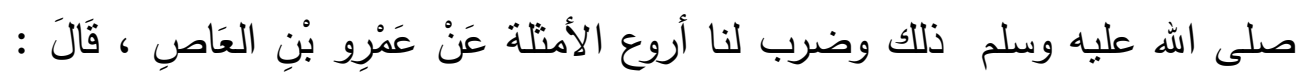

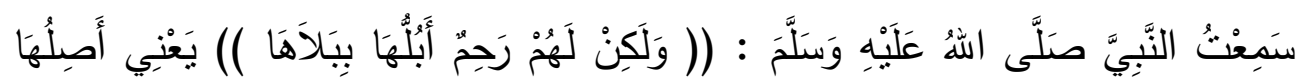

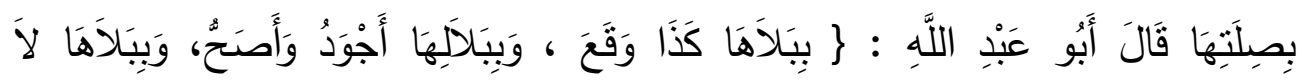

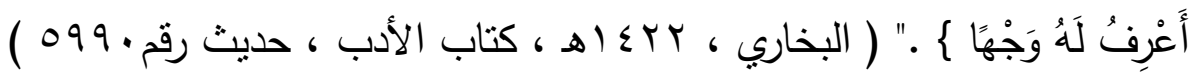

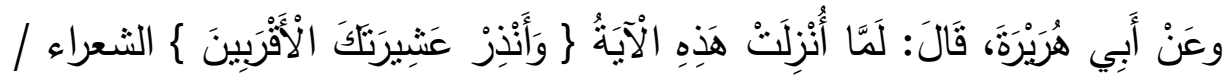

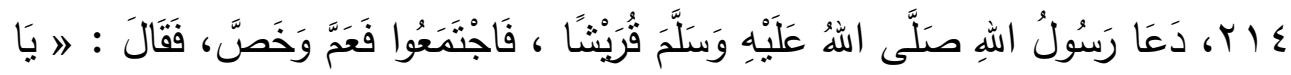

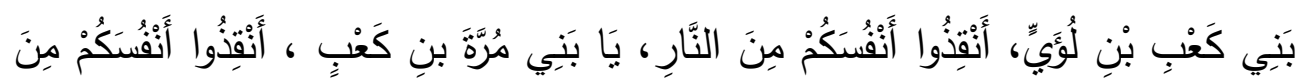

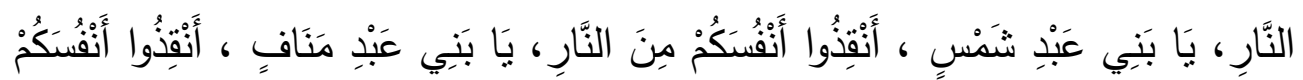

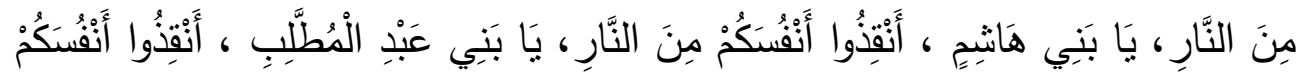

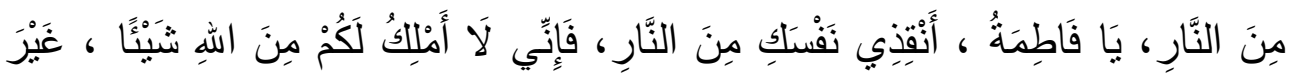

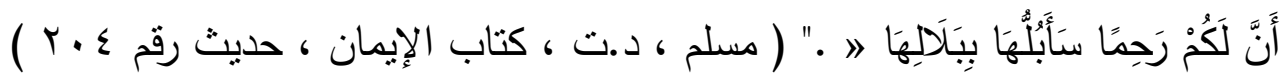
ويستفاد مما سبق أن الإسلام بما يدعو له من الأخلاق الفاضلة التي من جملتها صلة الأرحام لهو دين الحق ، فهو يدعو إلى تماسك المجتمع ووحدته وصلة الأرحام تؤكد هذا المعنى وتقويه ، في نفوس أفراد المجتمع المسلم وتبقى على أواصر الصلة بين أفراد هذا المجتمع قوية ومتينة ، ولذلك كان من أول ما دعا إلبه سيد البشرية محمد -صلى الله عليه وسلم- بعد التوحيد أن دعا إلى صلة الأرحام وعدم قطعها لأن في ذلك محافظة وتقوية لروابط المجتمع ويدل على هذا ما ورد في حديث عمرو بن

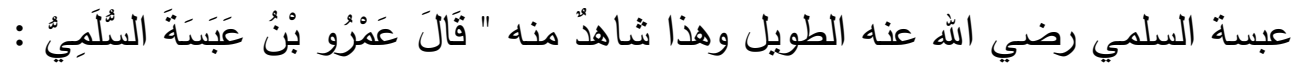

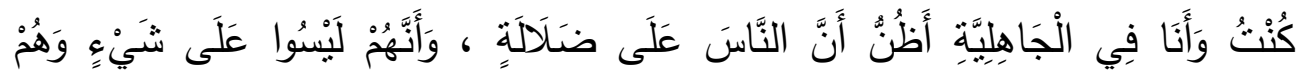




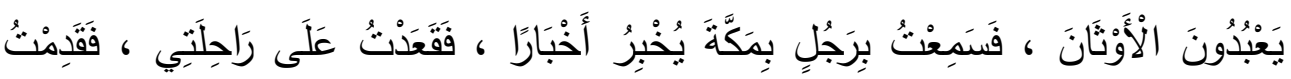

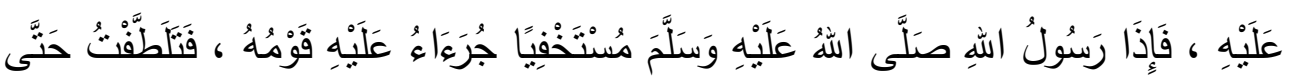

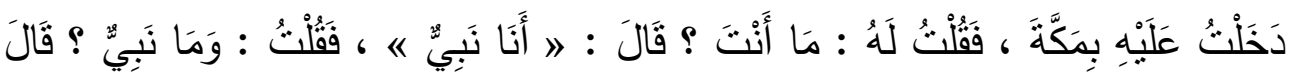

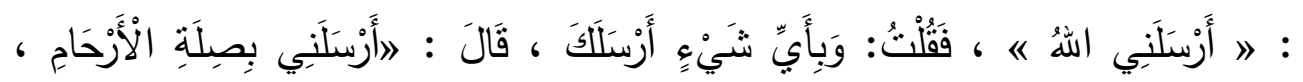

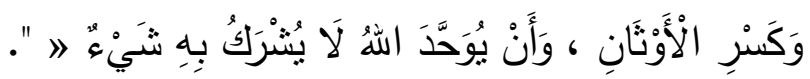

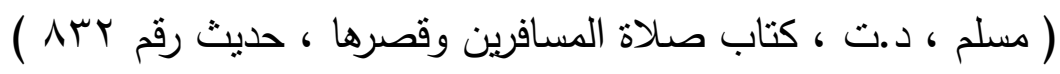

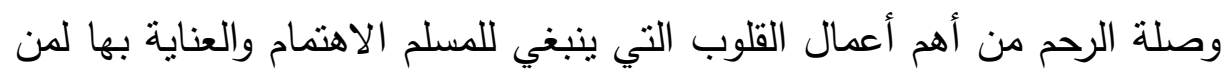

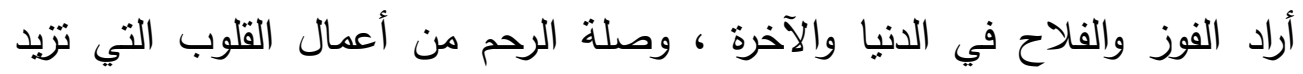

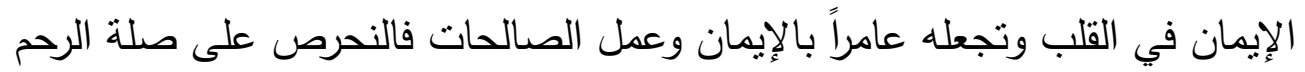

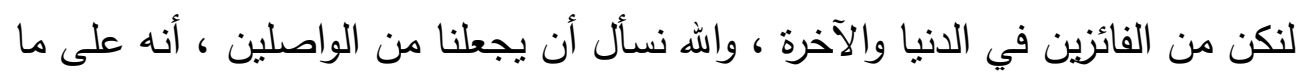
يشاء قدير. ويتضح مما سبق ، مما أورده ابن مفلح من مضامين تربوية اجتماعية في كتابه

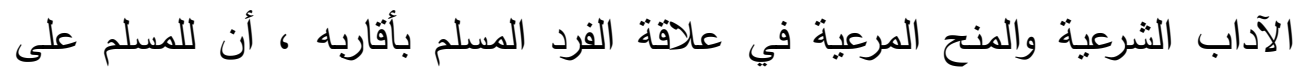

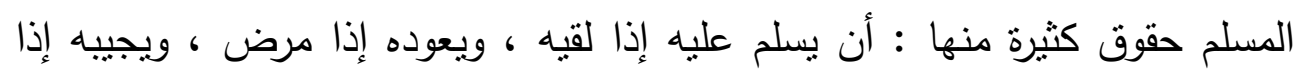

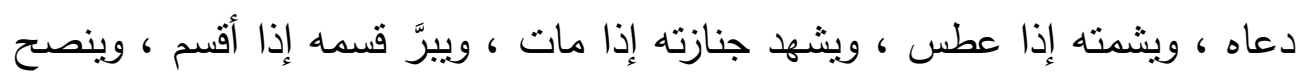

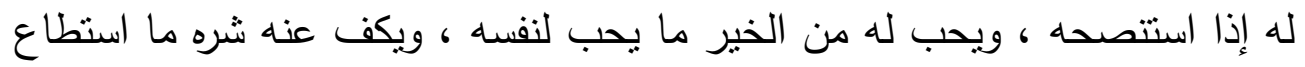

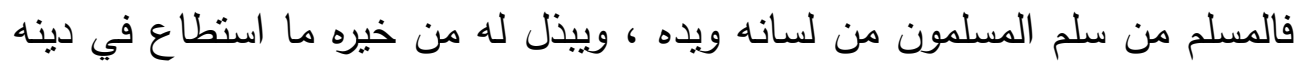
ودنياه ، فإن لم يقدر على شيء فكلمة طيية . فإن كان من القرابة فيزيد على ذللك

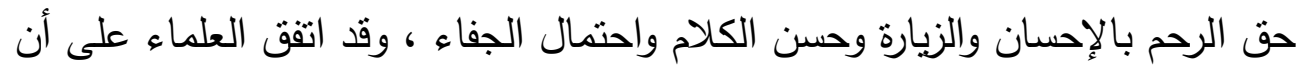

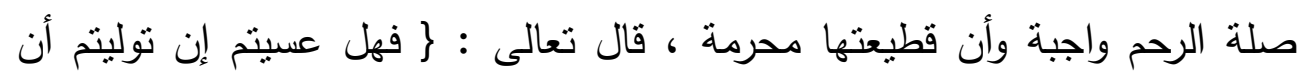

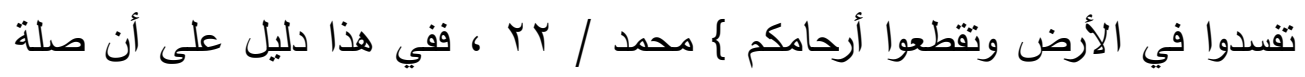

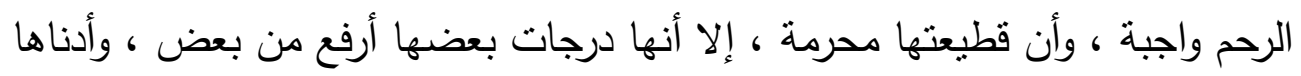
ترك الهجر ، والصلة بالسلام والكلام ـ وتختلف هذه الدرجات باختلاف القدرة والحاجة 
، فمنها الواجب ومنها المستحب ، إلا أنه لو وصل بعض الصلةِ ولم يصل غايتها لا يسمى قاطعاً ، ولو قصّر عما يقدر عليه وينبغي له لا يكون واصلاً ـ أما حدّ الرحم التي تجب صلتها ويحرم قطيعها : فهو القرابات من جهة أهل الإنسان كأبيه وجده وإن علا ، وفروعه كأبنائه وبناته وإن نزلوا ، وما يتصل بهم من حواثي كالإخوة والأخوات ، والأعمام والعمات ، والأخوال والخالات ، وما يتصل بهم من أولادهم برحم جامعة .

\section{المطلب الرابع :- ما المضامين التريوية الاجتماعية المتعلقة بحقوق} - الإنسان

\section{حقوق الإنسان في الإسلام : :}

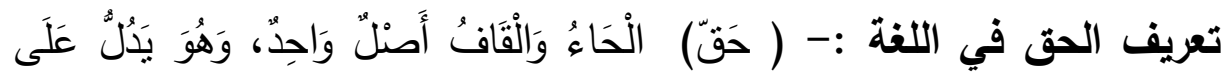

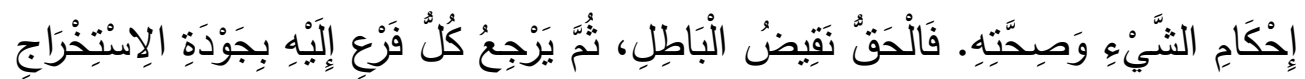

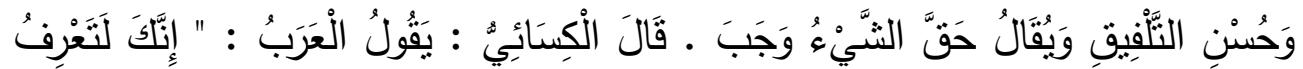

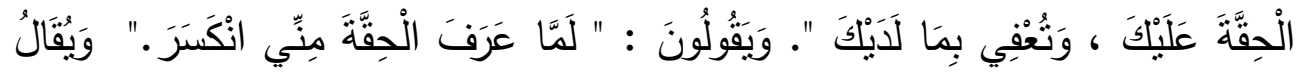

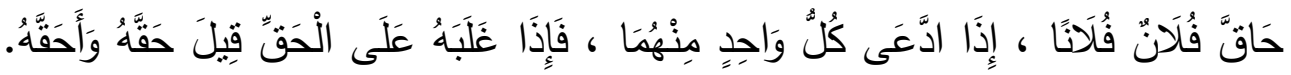

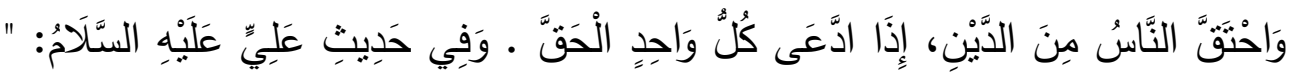

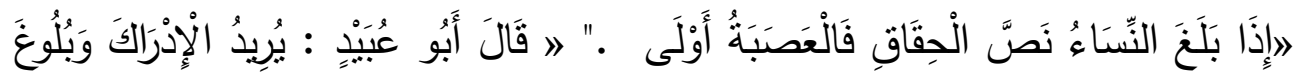

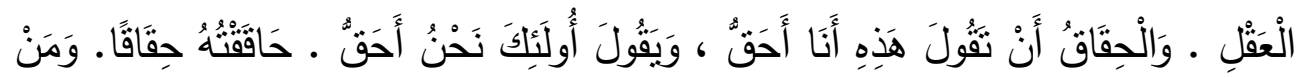

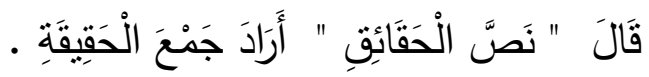

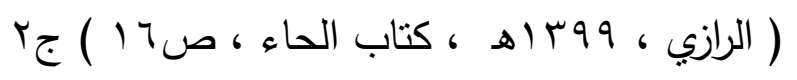

ولقد ذكر ابن مفلح في كتابه الآداب الثرعية الجزء الأول " الزم الحق ، فإنما ثقلت موازين من ثقلت يوم القيامة باتباعهم الحق في الدنيا وثقله عليهم ، وحُق لميزان إذا وضع فيه الحق غدا أن يكون ثقيلا ، وانما خفت موازين من خفت موازينه يوم 
القيامة باتباعهم الباطل في الدنيا وخفته عليهم ، وحُق لميزان وضع فيه الباطل أن

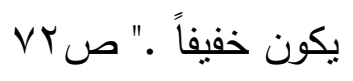

تعريف الحق في الاصطلاح :- قيمة مستحقة للإنسان تمكنه من حياة كريمة

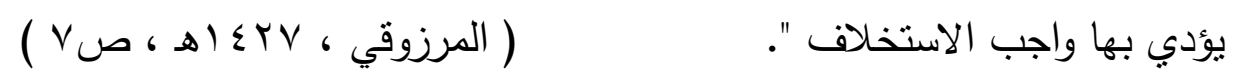

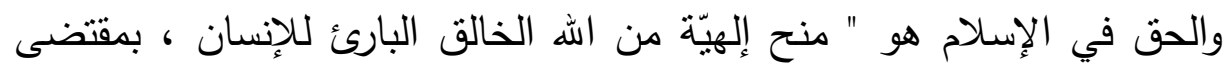

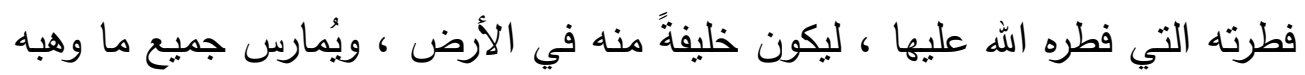

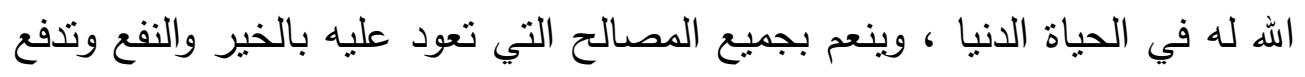
عنه الثرّ والسوء ، فهي حقوق شخصيّة للإنسان ، ومطلب مَصون ومُققسّ للنّاس

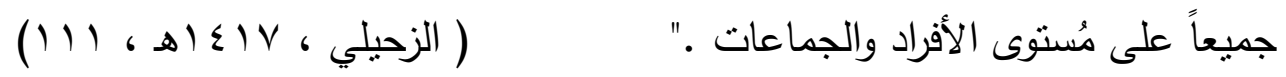

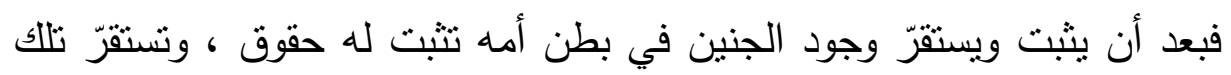

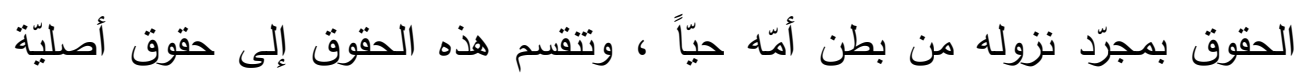

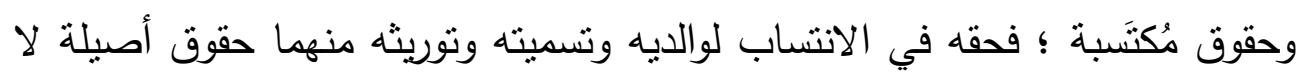

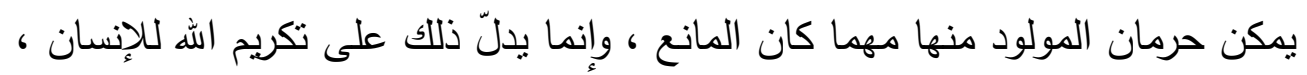

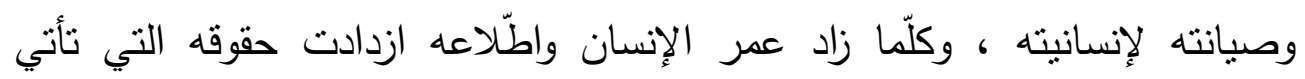

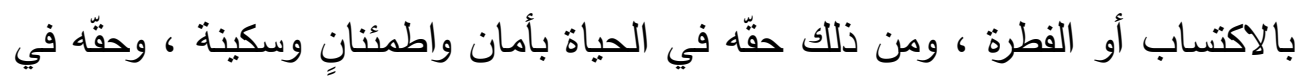

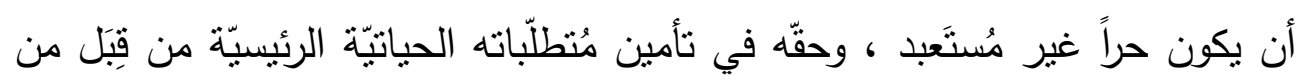

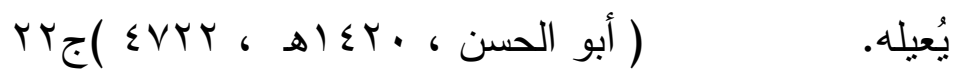

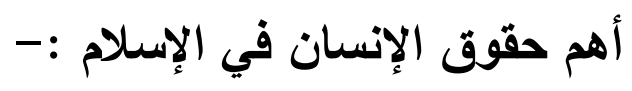

$$
\begin{aligned}
& \text { 1. تكريم الإنسان :- }
\end{aligned}
$$

لم تعرف البشرية على مدار مراحل تاريخها منذ هبط آدم إلى الأرض وإلى يومنا

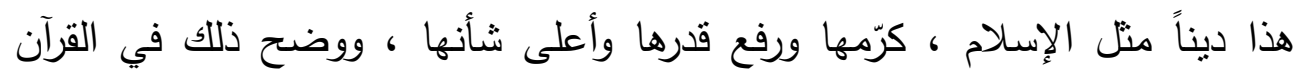

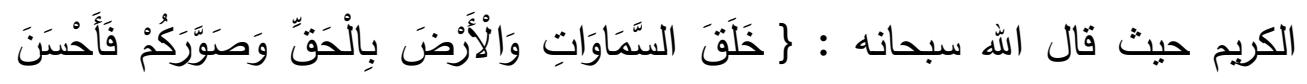

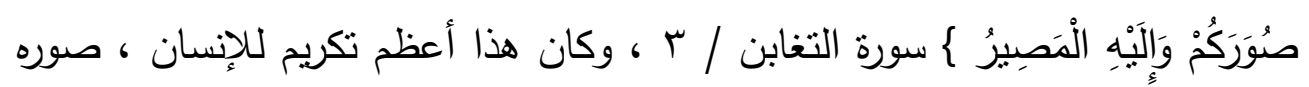


الله في أجمل هيئة وأحسن صورة ، ومن هنا استقى المصلحون القيم النبيلة ، وما ارتضاه الناس من القواعد الاجتماعية العالية التي تحفظ للفرد كرامته ، ثم وضعوا من القوانين الوضعية ما بصون خصوصية الإنسان الذي خلقه الله واستخلفه في الأرض ومنحه الحرية التي بها يصون كرامته ، وله من إرادته ما يجعله يفعل ما يريد دون ضغط أو إكراه ، ومن أجل ذلك بعث اله الأنبياء هداة مرشدين ، وعلى لسان كل رسول جاء تكريم الإنسان ، واقتضت مشيئة الله سبحانه وتعالى أن يكون سيدنا محمد صلى الله عليه وسلم هو خاتم الأنبياء الذي أعلن من أو لحظة تتبؤه أن الإنسان حرّ في حياته مكرم من الله خالقه وهاديه وربه ، وهذا الانسان لا يستهان به ، ولا

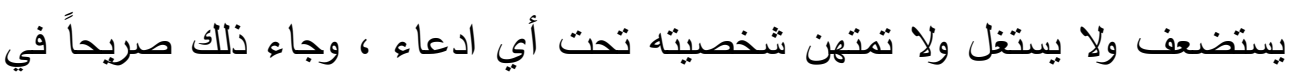

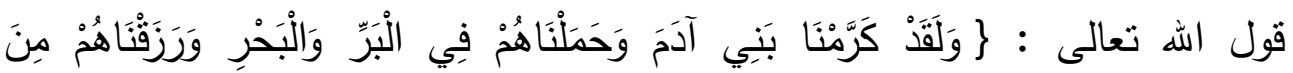

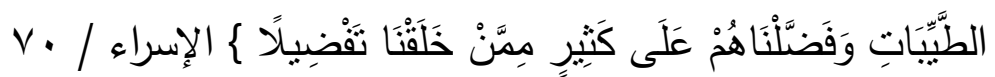

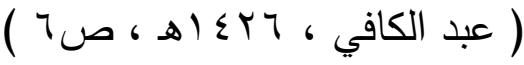

وقد خصّ الله الإنسان من بين المخلوقات فاستخلفه في هذه الأرض ، وسخّر له هذا الكون وأمدّه بإمكانيات عقلية وجسمية ، وابتلاه بالخير والثر ، وأمره ونهاه ووعده

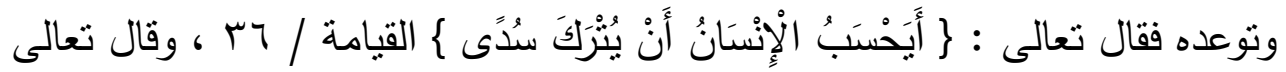

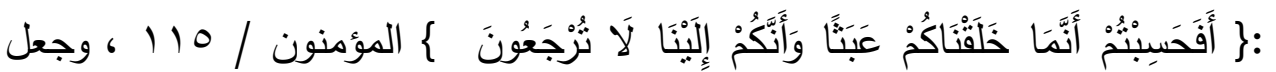

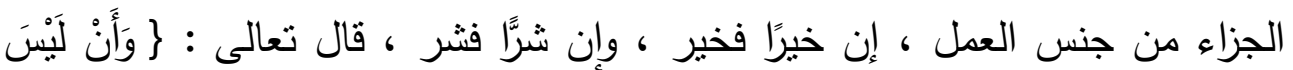

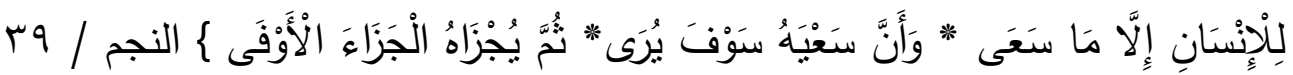

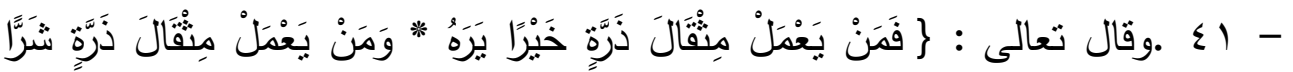

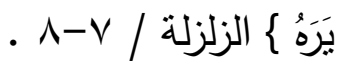

\section{Y.حق التعليم :-}

التعليم من الحقوق الأساسية للإنسان ، إذ ميزه الله تعالى بالعقل و يجب عليه أن يستثر هذا الجزء العظيم الذي و هبه الله إياه ، وإن الله تعالى عندما خلق آدم 
عليه السلام علّمه أسماء كل المخلوقات ، فكان العلم والتعليم ركن أساسي منذ خُلق القِ

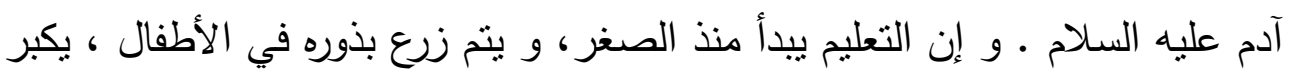

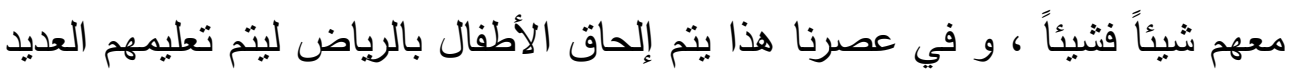
من الأثياء ، بدايات الأبجديات ، بالإضافة إلى إلى السلوكيات والتعامل ، ثم يكبر الطفل

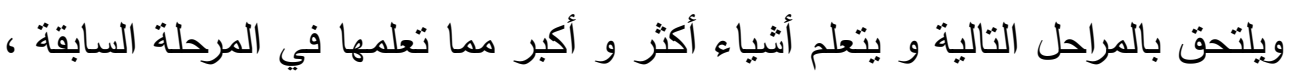

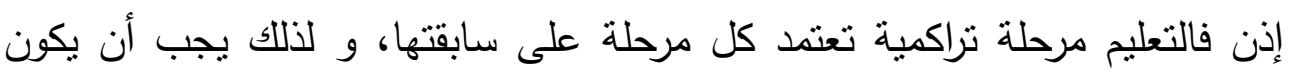

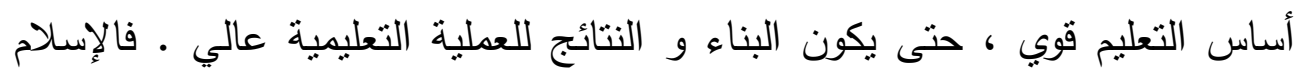

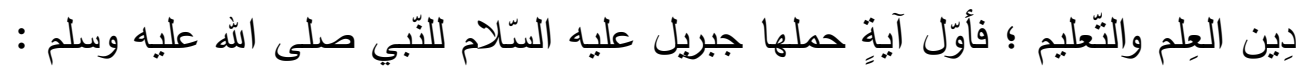

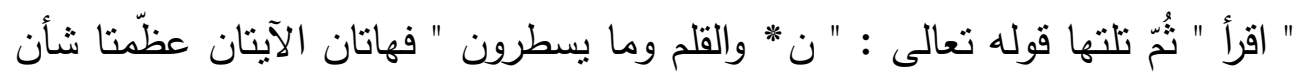

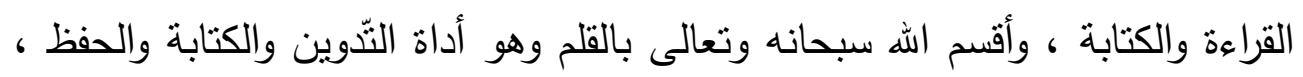

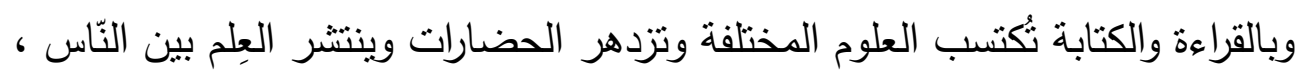

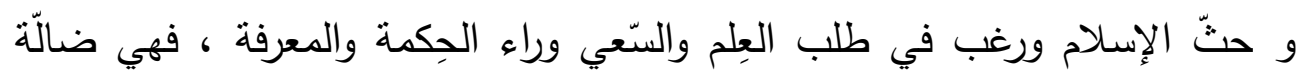

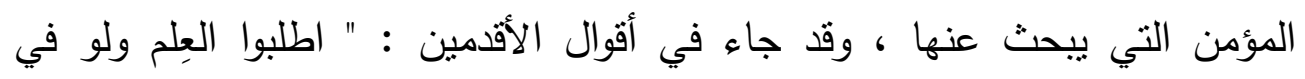

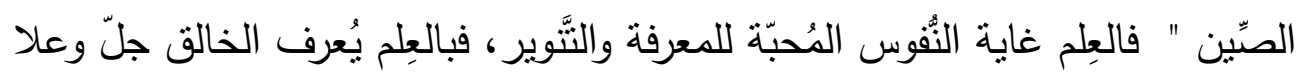

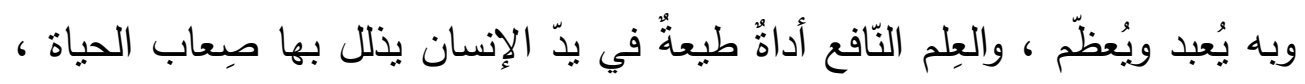

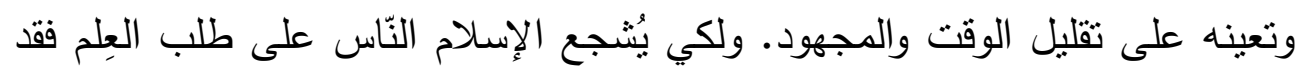

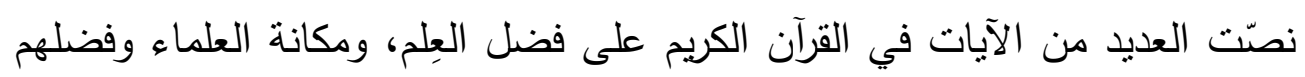

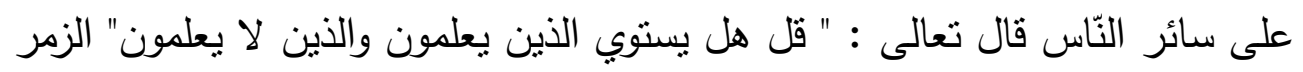

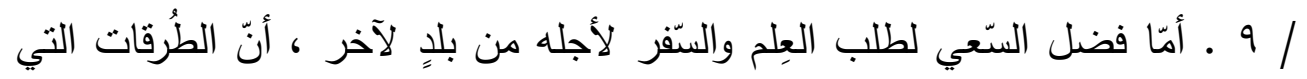

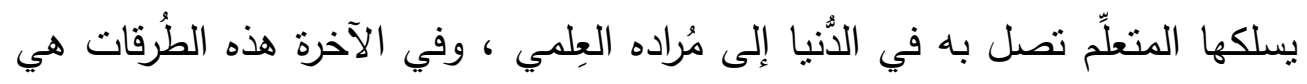

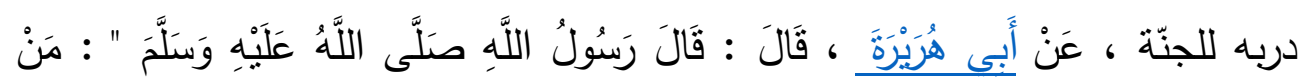

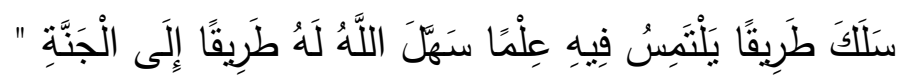

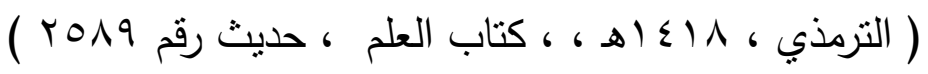


فإذا تعلَّمت آيةًً ، تعلَّمت قراعتها ، وتعلَّمت معناها ، وعملت بها ، ارتقبت ، واله

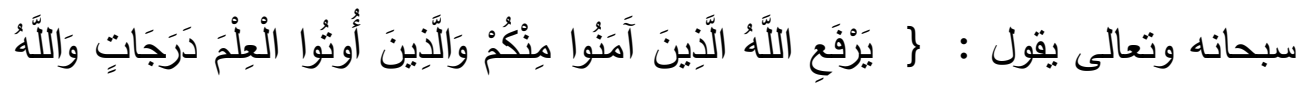

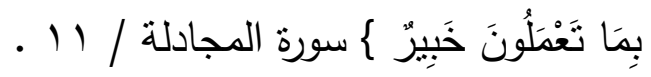
ولقد ذكر ابن مفلح في كتابه الآداب الثرعية الجزء الثاني " النبي صلى الله عليه وسلم يقول : " الدنيا ملعونة وملعون ما فيها ، إلا ذكر الله وما والاه ، وعالماً ومتعلماً

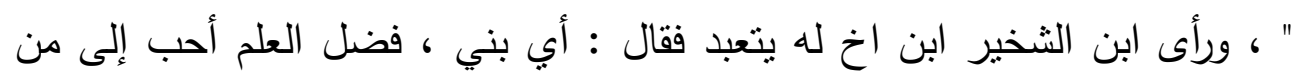

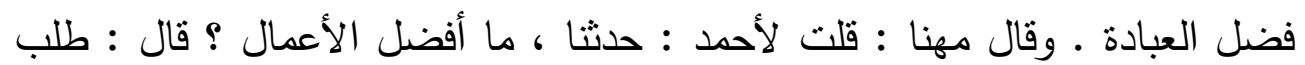
العلم ، قلت : لمن ؟ قال : لمن صحت نيته ، قلت : وأي شيء بصحح النية ؟ قال ينوي يتواضع فيه ، وينفي عنه الجهل . صرى وفي هذا دليل على أهمية طلب العلم للإنسان وهو حق من حقوقه يرتفع به درجات عند الله سبحانه وتعالى ، فالعلم سبباً للرفعة عند اله ، وعند الناس ، وعند النفس ، لأن رتبة العلم أعلى الرتب ، ولا أذلَّ بعلٍٍ قط ، فالجهل قبيح وصاحبه ذليل ، والعلم جيّّ وصاحبه عزيز ، فإذا أردت عزَّ الدنيا والآخرة فعليك بالعلم ، وعليك بطلب العلم

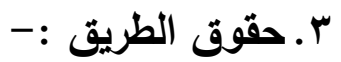

لقد تميَّزَ الإسلام من بين سائر الأديان والنظم أنَّهُ دينٌ راعى موضُوعَ الأخلاق

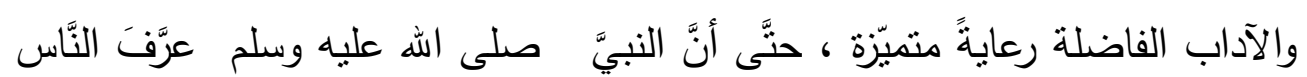
حقيقةَ دعوته فقال " : إنما بُعثتُ لأتمّمَ مكارَّ الأخلاق ." ألاَ وإِنَّ من أعظم الآداب

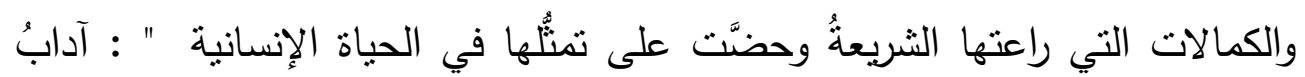

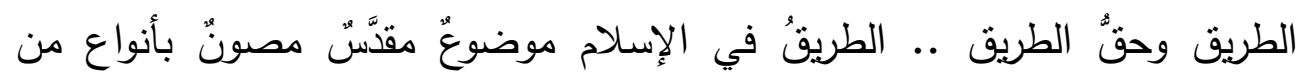

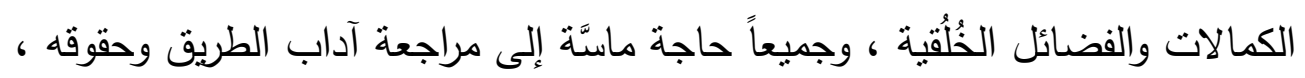
لأثنّا في حاجة إلى أن نصونَ طُرُقنا ونرتقي بها وفق ما يتتاسبُ مع إسلامنا وإيماننا وشريعتا التي جاءت لنتمّ مكارم الأخلاق . 
ومما دعا اليه الإسلام في حفظ حقوق الطريق ما يلي :أ - غض البصر :الأمر بغض البصر يشترك فيه الرجال والنساء على حد سواء فتعدد النظر يورث القلب علاقة يتعذب بها الإنسان • بهرك ب - كف الأذى: ومن حقوق الطريق ، كف الأذى وعدم إيذاء الناس في أبدانهم

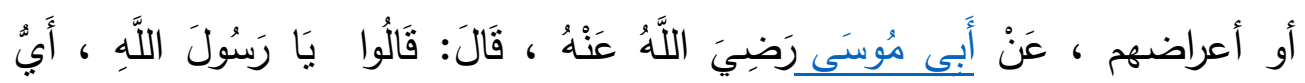

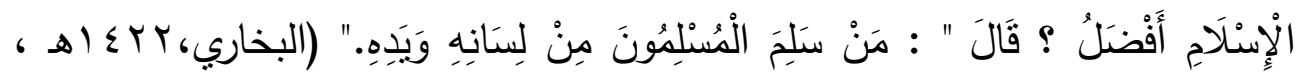

$$
\text { كتاب الإيمان ، حديث رقم · ( ) الإنم }
$$

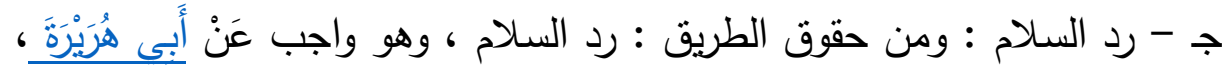

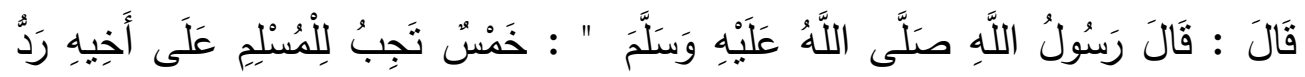

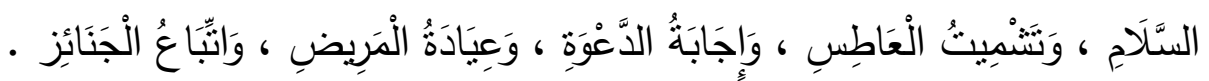

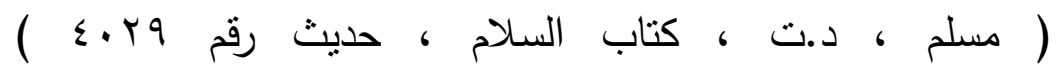
د - وجوب الأمر بالمعروف والنهي عن المنكر :هذا باب عظيم الثأن والقدر، به

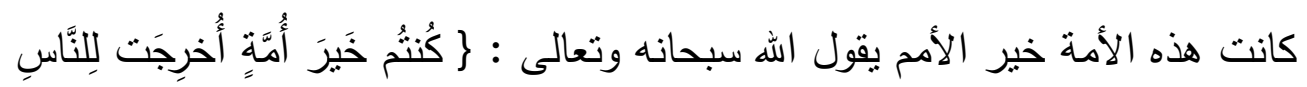

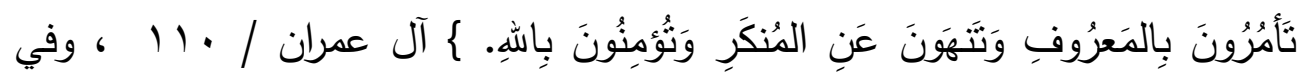
الأمر بالمعروف والنهي عن المنكر فوائد عظيمة للأمة ، منها : نجاة سفينة المجتمع بله من الهلاك والغرق ، ومنها قمع الباطل وأهله ، ومنها كثرة الخيرات والحد من الثرور

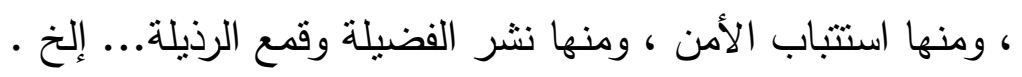
هـ - إزالة الأذى من الطريق : من الآداب المستحبة في الطريق ! إزالة الأذى الطى

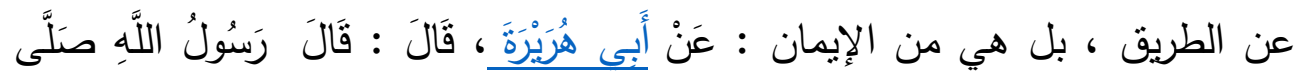

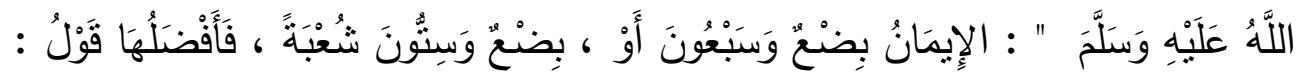

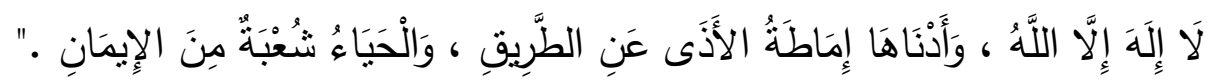

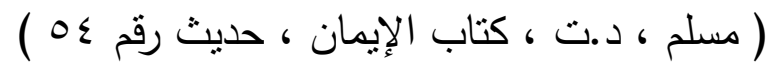


وهي من الصدقات ، وبسبيها أدخل رجل الجنة ، ففي حديث أبي هريرة قال :

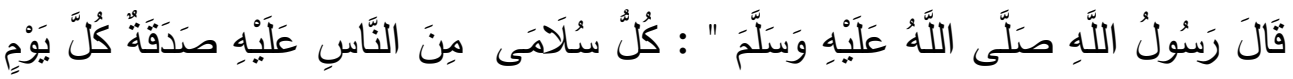

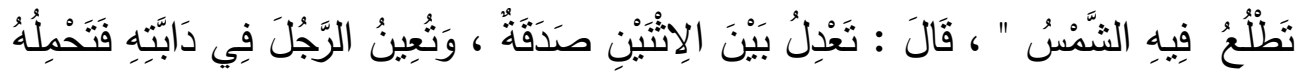

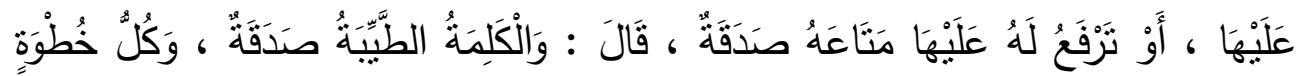

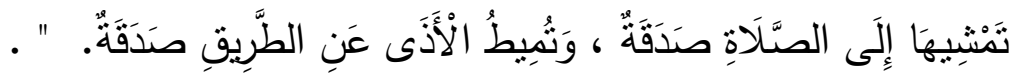

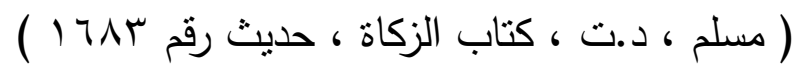

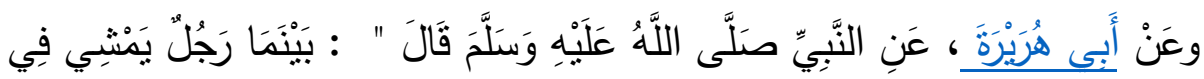

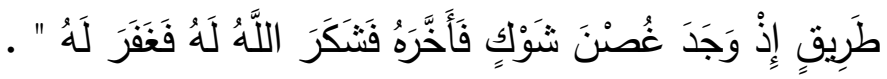

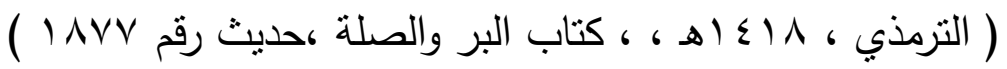

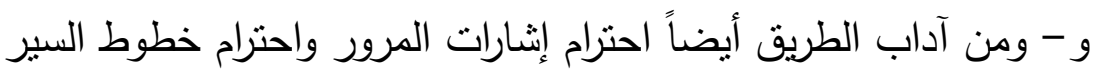
وعدم إيقاف السيارات في أماكن ممنوع الوقوف فيها ،وعدم القيادة بسرعة خصوصاً بالأماكن المزدحمة ، وأماكن تواجد الأطفال ، كالمدارس ، والمساجد والأسواق ، وعدم استخدام العنف والتصرف باعتدال . عدم التعرض لحيوانات الثوارع وتعذيبها كالكلاب والقطط ... ولقد ذكر ابن مفلح في كتابه الآداب الثرعية الجزء الثالث " يستحب الكف عن مساوئ الناس وعيوبهر ، ويكره الجلوس على الطرقات للحديث ونحوه لما فيه من التعرض للفنن والأذى • وفي الصحيحين أو احدهما عنه صلى الله عليه وسلم :" منه اجتبوا مجالس الصعدات " فقلنا : إنما قعدنا لغير ما بأس ، فعدنا نتذاكر ونتحدث ، وكنى

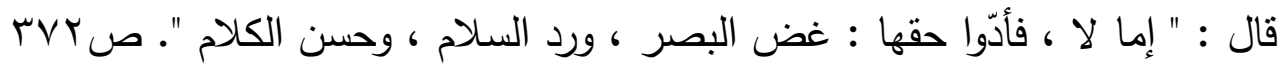

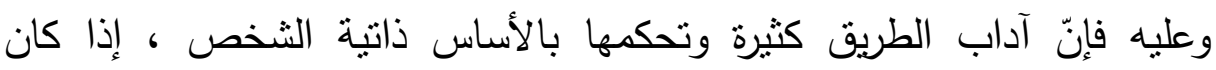
شخص واعياً ملماً بكل ما يتعلّق بآداب الطريق ، لأنه في الأصل يعكس صورة نفسه

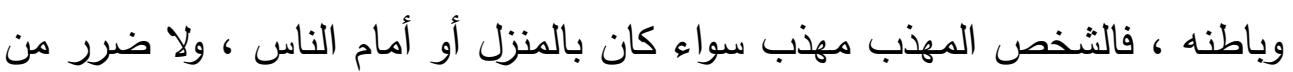
نشر الوعي والإرشاد المستمر من قبل المؤسسات الدينية والتربوية ، التي تصب في 
مصلحة واحدة ألا وهي نشأة الفرد نشأة مثالية ، تعكس صورة رائعة عن نفسه ومجتمعه ووطنه .

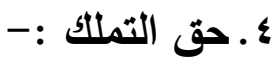

صان الإسلام حقوق الإنسان المختلفة ، ولبَّى احتياجاته الفطرية التي لا تستقيم

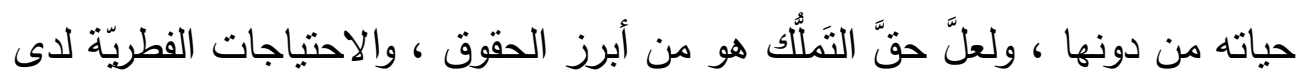
كل إنسان ، ولقد سلك الإسلام مسلكاً وسطياً فريداً من نوعه فيما يتعلَّق بحق التملُّك ومن أبرز ملامح هذا المسلك أنّه استطاع إثباع احتياجات الإنسان الفطريّة ، وحفظ بـان حقوق المجتمع في بعض الملكيّات في الوقت ذاته ؛ وذللك من خلال وضع بعض هـ القيود المنطقية على حق التملك ؛ لذا فإنّه يمكن القول أنّ الإسلام أقرَّ الملكيتين : الفرديّة ، والجماعيّة على حدٍ سواء . فالإسلام ينظر إلى الملكيّات عل اختلاف

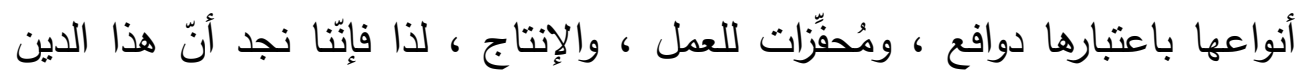

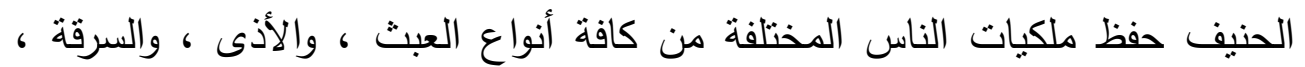

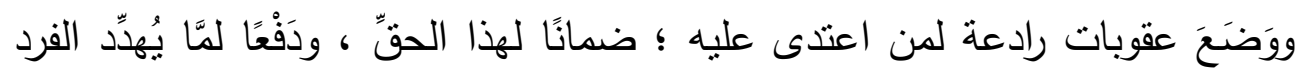
في حقِّه المشروع ، كما أن الإسلام رثنَّبَ على هذا الحقِّ نتائجه الأخرى ؛ وهي : حُرِّبَّة التصرُّف فيه بالبيع ، والثراء ، والإجارة ، والرهن ، والهبة ، والوصية ، وغيرها

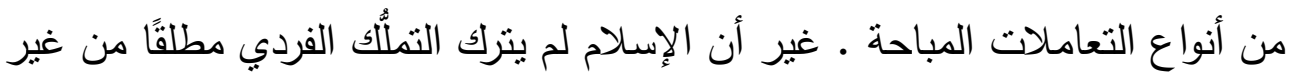

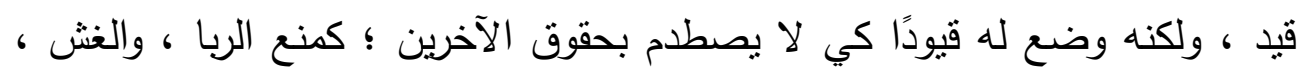
والرشوة ، والاحتكار، ونحو ذلك ممَّا يصطدم ويُضَيِع مصلحة الجماعة ، وهذه الحرية

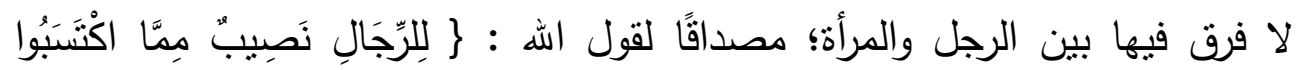

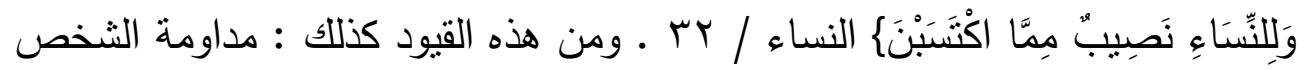
على استثمار المال ؛ لأن في تعطيله إضرارًا بصاحبه ، وبنماء ثروة المجتمع . وأيضًا أداء الزكاة على هذا المال إذا بلغ النصاب وحال عليه الحول ؛ لأن الزكاة حق لت المال . ومن الأمثلة الثائعة على الملكية العامّة : المساجد ، والدوائر الحكوميّة 
والمستشفيات ، والمدارس ، والطرق ، وما إلى ذلك . وهذا النوع من الأملاك محفوظ

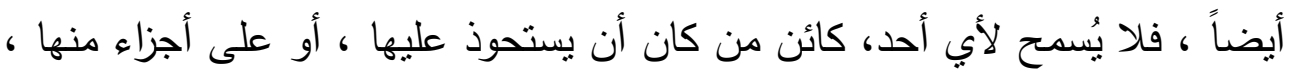

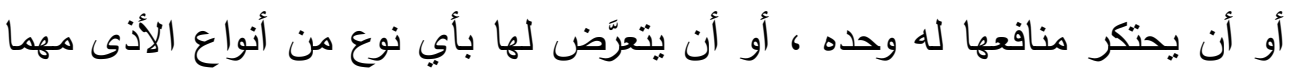

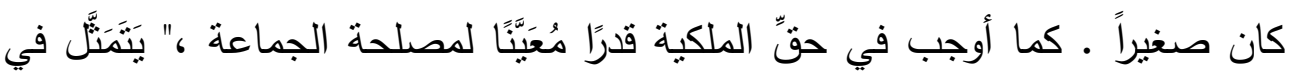
الزكاة والنفقات الثرعية ، وعدم جواز الوصية بأكثر من التُّربثِ ؛ حفظًا لحقِّ الوارثين في النلثين • وكذلك قيَّده بالاعتدال في الإنفاق دون إسراف أو تقتير، قال تعالى: \}

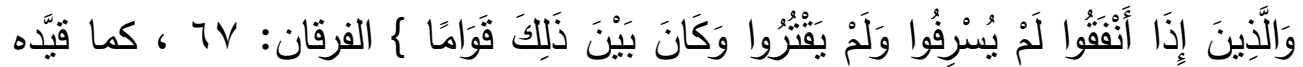

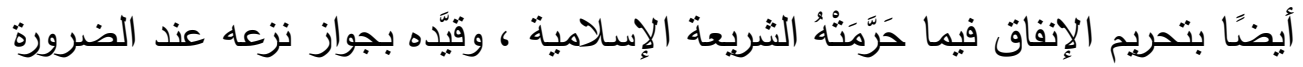
للمصلحة العامَّة مع تعويض صاحب المِلْكِ التعويضَ العادلَ ، كنزع المِلْلِكِ لتوسعة

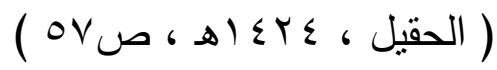

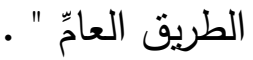
وعليه فإن لكلّ شخص الحق في التملك والاستفادة من ممتلكاته بدون تدخّل الآخرين • واستخدام الناس لأملاكهم بحريّة يُعبّر عن حرّيتهم الثخصيّة ، ويُكسبهم الأمان ويوفر احتياجهم • ولقد ذكر ابن مفلح في كتابه الآداب الثرعية الجزء الثالث " يسن التكسب ومعرفة أحكامه ، حتى مع الكفاية ، نص عليه ـ قاله في الرعاية ، وقال ايضاً فيها : يباح كسب الحاد لزيادة المال والجاه والترفه والتتعم والتوسعة على العيال مع سلامة الدين والعرض والمروءة وبراءة الذمة . وقال ابن حزم : اتفقوا على ان الاتساع في

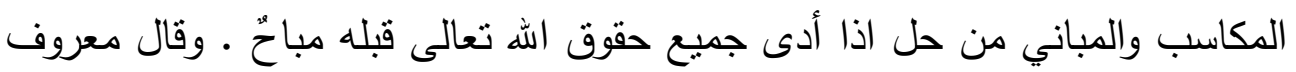
الكرخي : من اشترى وباع ولو برأس المال بورك فيه كما يبارك في الزرع بماء المطر

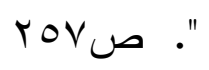

\section{ه. حق العدل والمساواة بين الناس :-}

من عظمة الإسلام أنه يَمزجج بين العدل والمساواة ؛ فالحق أنه لا حرية ولا مساواة بلا عدلٍ ، وبلا شريعة حاكمة للناس جميعًا على قدم المساواة ، وكل شعاراتٍ تنسى 


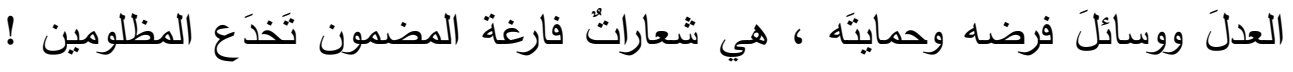

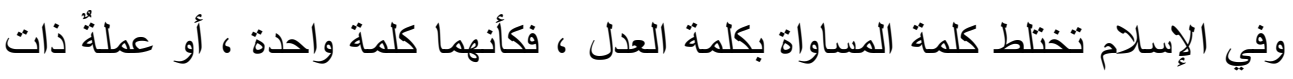

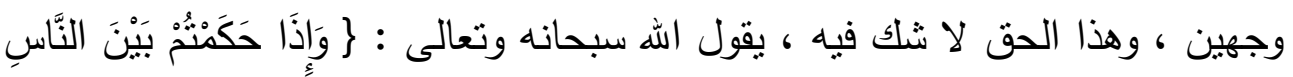

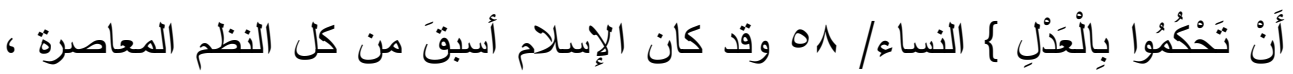

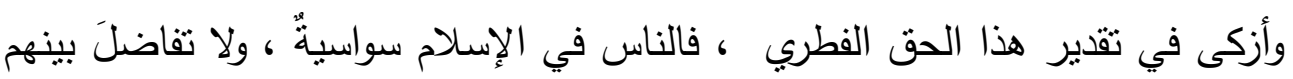

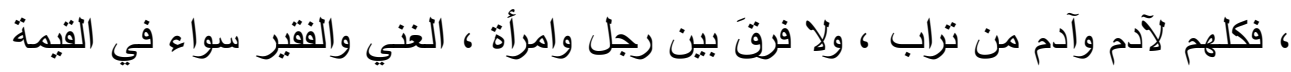

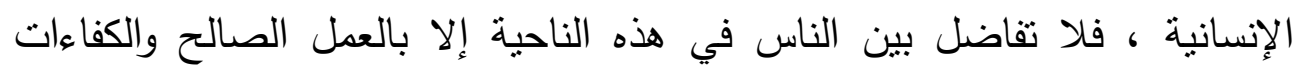

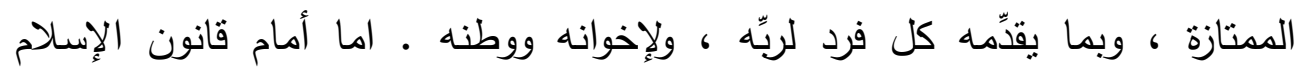

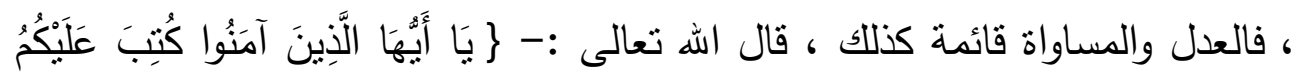

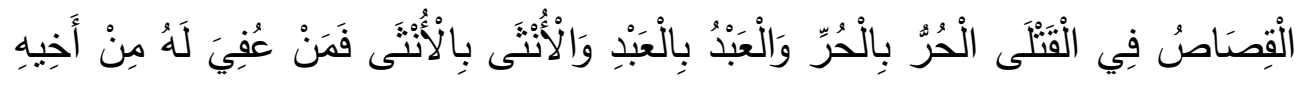

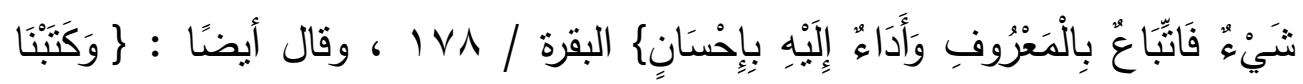

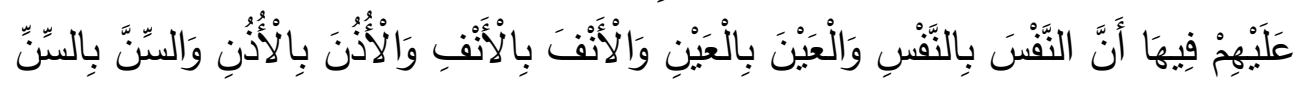

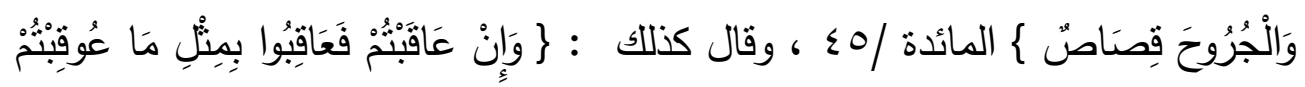

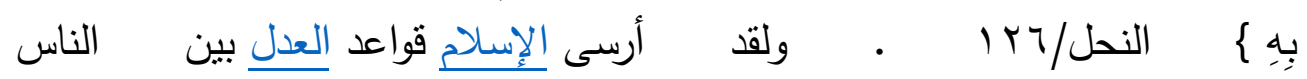

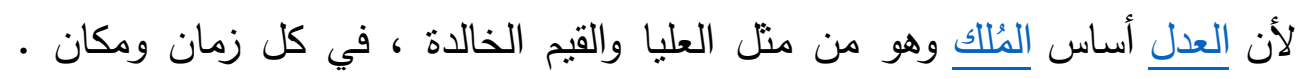

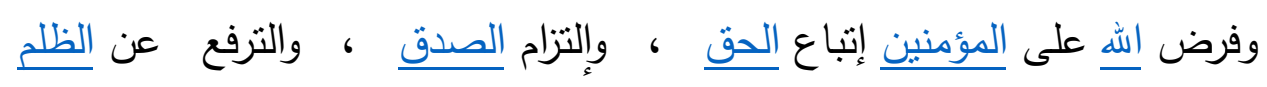

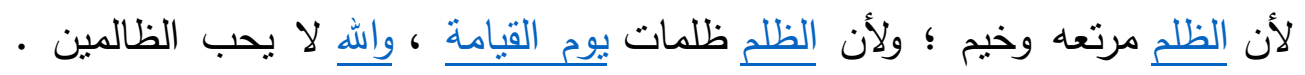

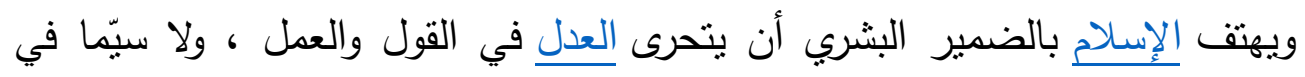

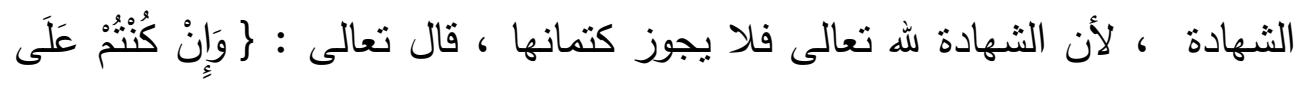

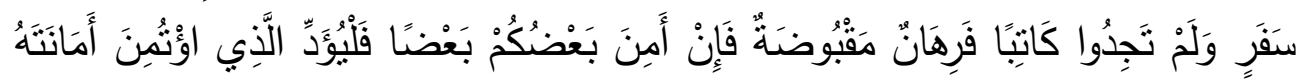

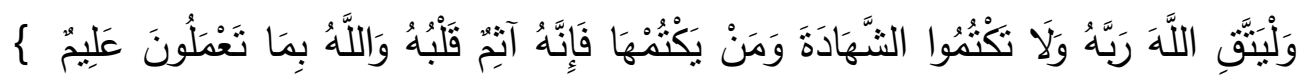

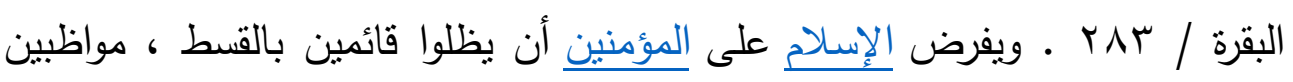

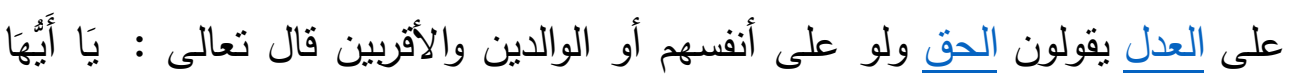




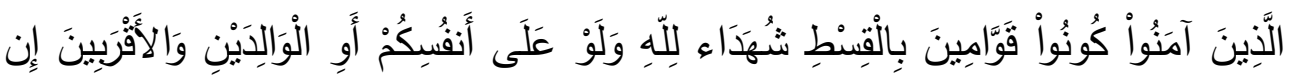

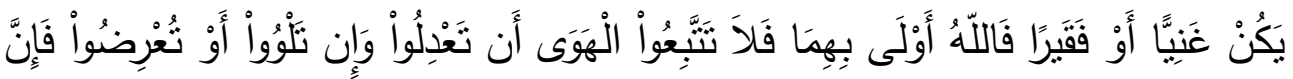

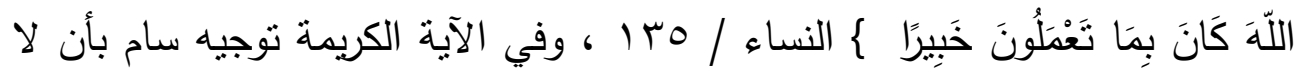

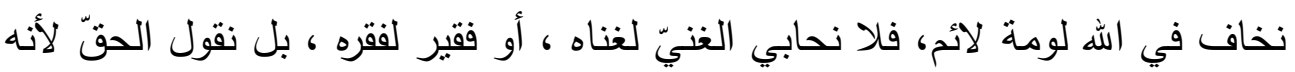

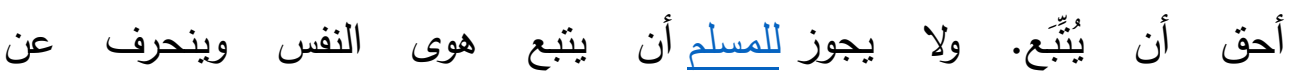

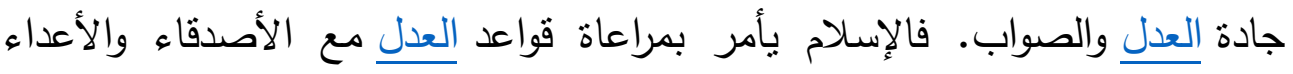

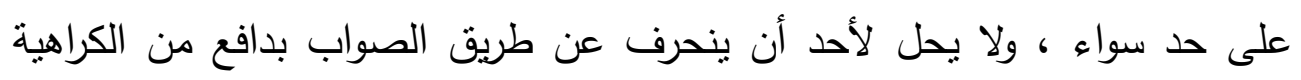

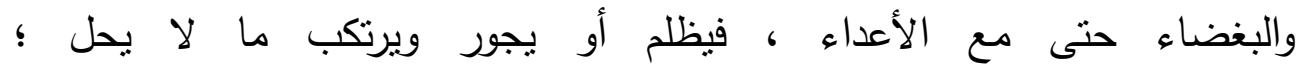

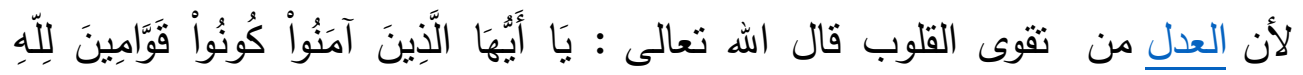

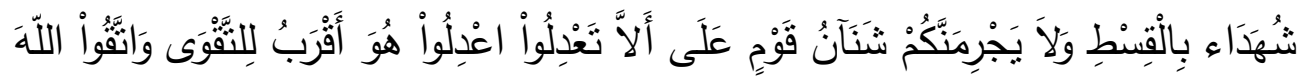

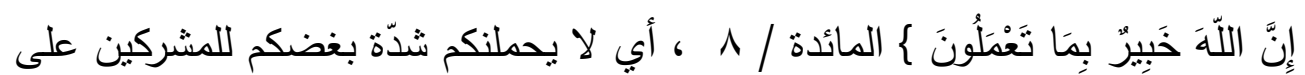

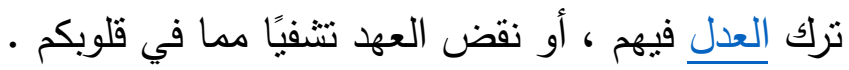

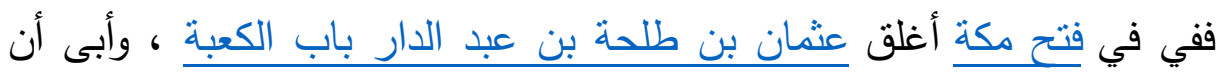

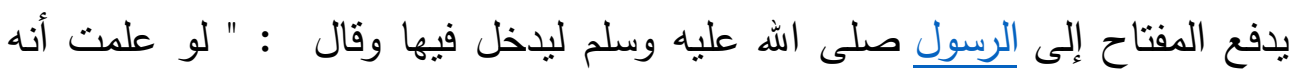

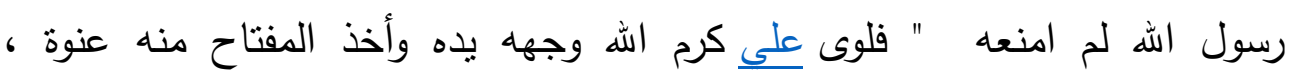

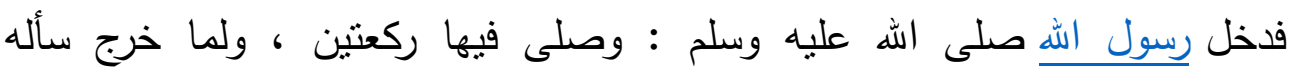

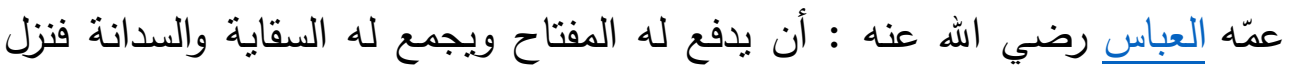

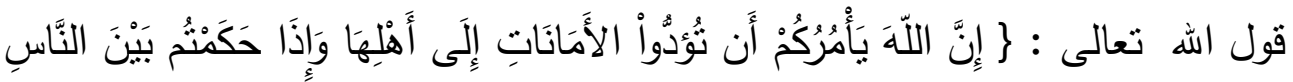

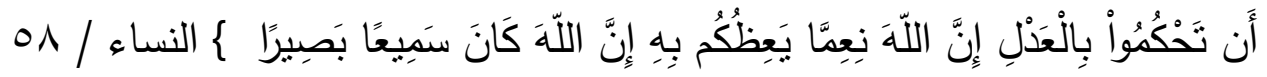

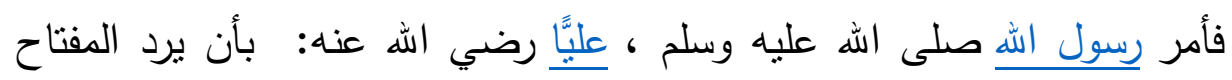
إلى عثمان بن طلحة ويعتذر إليه ففعل ذلك عليّ ، فصار ذلك سبيًا لإسلامه ـ ونزل

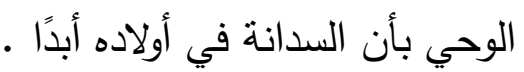


ولقد ذكر ابن مفلح في كتابه الآداب الثرعية الجزء الأول " وفي مسلم عن عبداله بن عمرو ، عن النبي صلى اله عليه وسلم قال : (( المقسطون يوم القيامة عند الله عز وجل على منابر من نور عن يمين الرحمن عز وجل - وكلتا يديه يمين

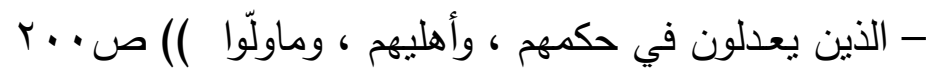

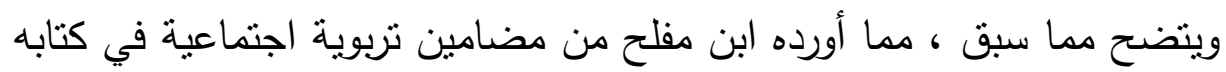

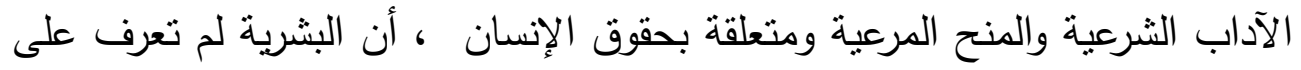

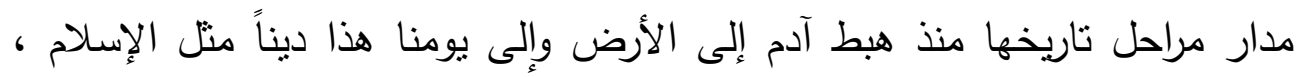

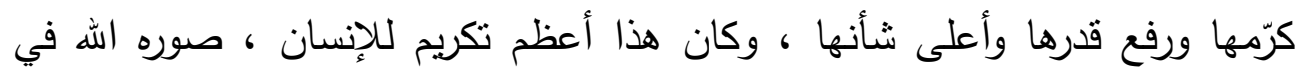

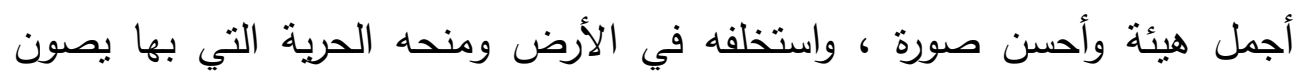

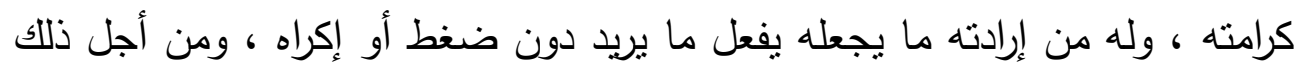
بعث اله الأنبياء هداة مرشدين ، وعلى لسان كل رسول جاء تكريم الإنسان ، وهذا الانسان لا بستهان به ، ولا يستضعف ولا بستغل ولا تمتهن شخصيته تحت أي ادعاء آناء

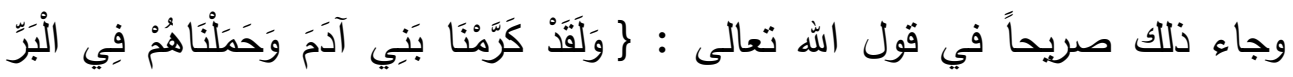

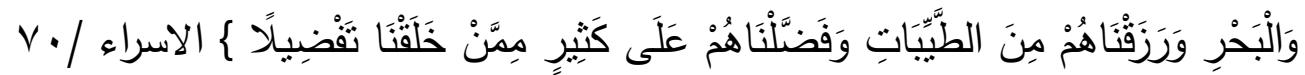
، وبالرغم من حفظ اله لكرامة الإنسان وحقوقه وحريته إلا أنه لا بد من وضعتها على

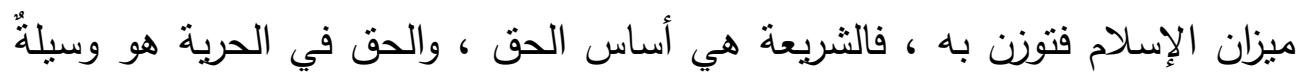

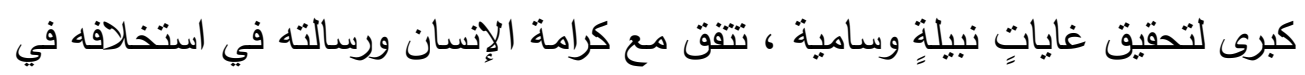

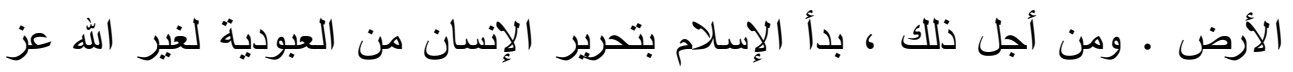

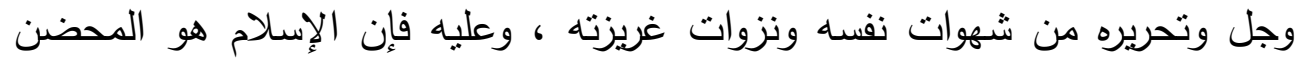

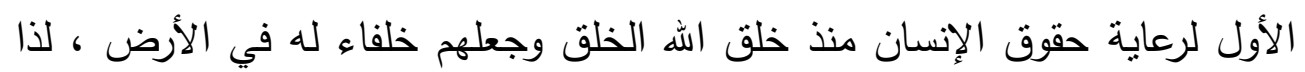

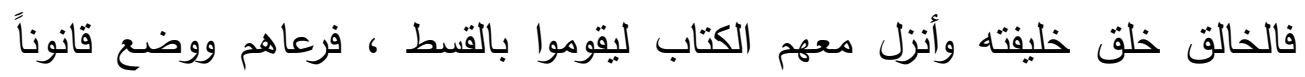

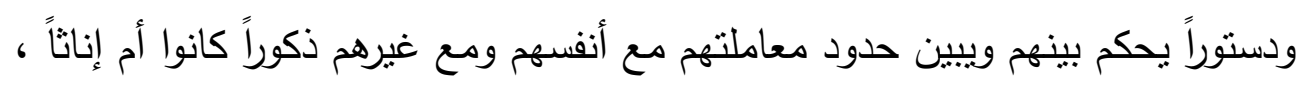

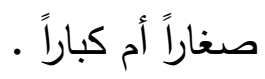


المطلب الخامس :- ما المضامين التريوية الاجتماعية المتعلقة بالآقات

\section{- المهددة للمجتمع}

هناك العديد من الآفات المنتشرة بين الناس وتهدد صلاح المجتمع ورقيه ومن

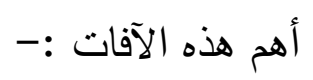

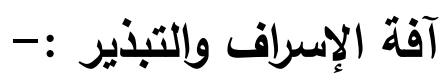

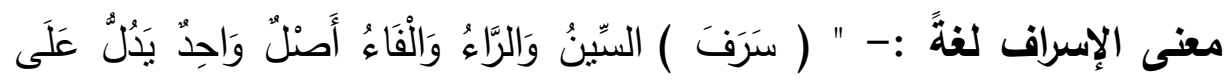

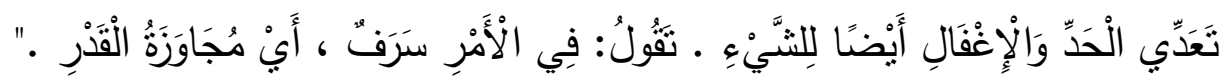

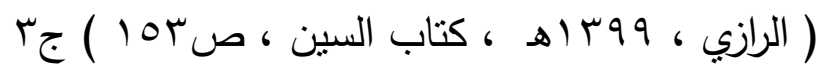

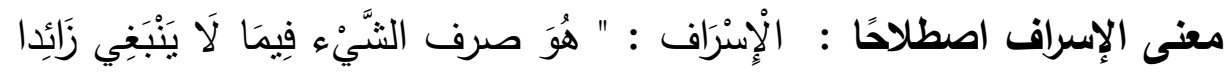

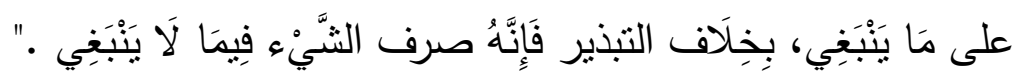

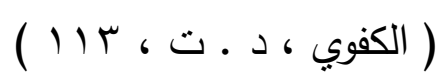

و" السَّرَفُ: تجاوز الحدّ في كلّ فعل يفعله الإنسان ، وإن كان ذلك في الإنفاق

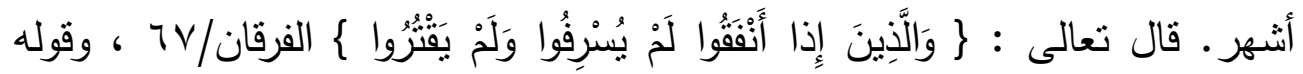

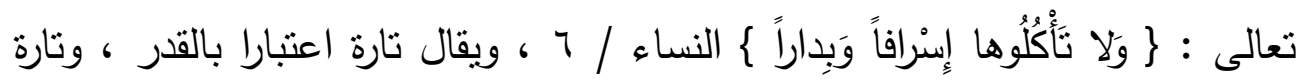
بالكيفيّة ، ولهذا قال سفيان: (ما أنفقت في غير طاعة الله فهو سَرَفْ ، وإن كان قليلا

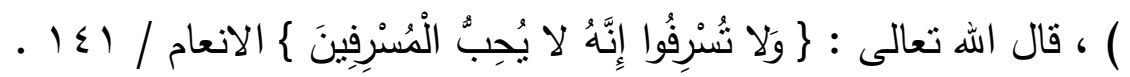
والإسراف : هو إنفاق المال الكثثير في الغرض الخسيس • وقيل تجاوز الحدّ في

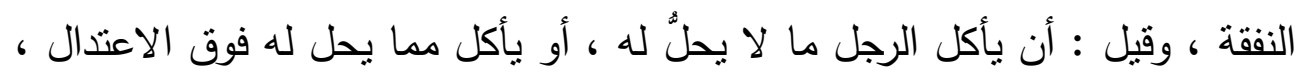
ومقدار الحاجة. وقيل : الإسراف تجاوز في الكمية ، فهو جهل بمقادير الحقوق " .

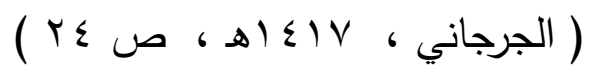




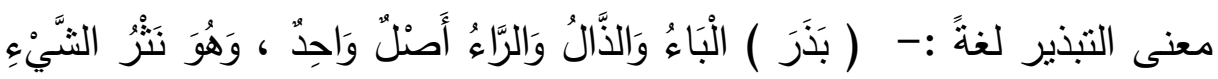

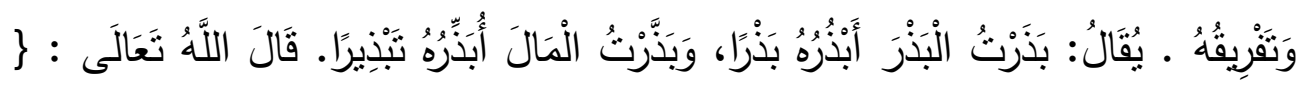

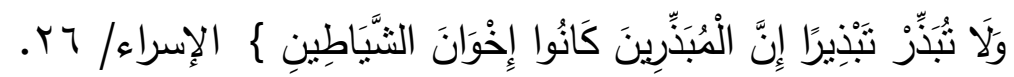

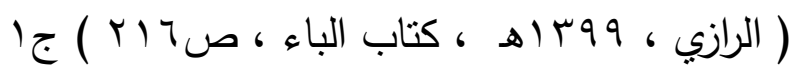

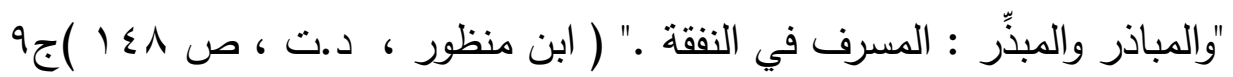

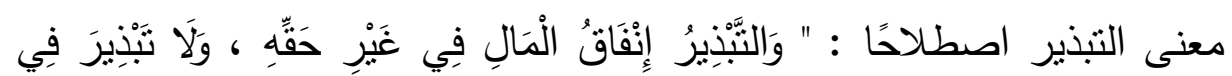

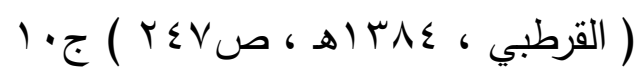
عَمَلِ الْخَيْرِ". " والتبذير: تفريق المال على وجه الإسراف ،وأصله إلقاء البذر فاستعير لكل

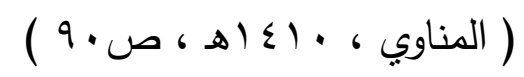
مضيع لماله." الفرق بين الإسراف والتبذير :- الإسراف يقصد به المبالغة في ما أباحه الله وفوق ما يحتاج ، مثال على ذلك أن نكون مائدة طعام أمامك ك 》البوفيه《 المفتوح ، فالثخص يقوم بملء طبقه حتى لو لم يكن محتاجاً لذلك ، فهذا معناه أنه أسرف في شيء مباح أي الطعام ؛ لأنه قد يأكل فقط نصف هذا الطبق والباقي سيرميه أو أخذ مثناً ثناث حبات من الفاكهة وهو بحاجة فقط لواحدة، فهذا هو الإسراف. أما التبذير، فهو يختلف تماماً ، فهو أن تصرف المال في ما حرم الله تعالى مثناً كأن يشتري شخص علبة سجائر . أو أب شيء من المحرمات . وعلينا جميعاً أن أن نفهم أن الإنسان محاسب على الاثثين : الإسراف ؛ لأن الإنسان سيأخذ شيئاً فوق

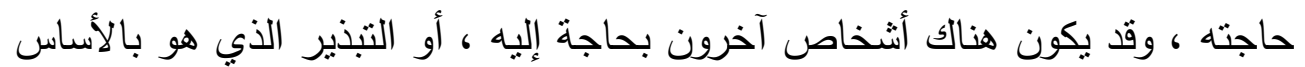
الإنفاق في أمور محرمة ؛ لذا علينا أن نتجنب الإسراف والتبذير لكي ننال رضوان الله

أسباب الإسراف :- للإسراف والتبذير أسباب وبواعث توقع فيه ، وتؤدي إليه ، تعالى . ونذكر منها :-- 
ا • جهل المسرف بتعاليم الدين الذي ينهى عن الإسراف بشتى صوره ، ومن نتيجة جهل المسرف بتعاليم الدين مجاوزة الحد في تتاول المباحات ، فإن هذا من أن المن شأنه أن يؤدي إلى السمنة وضخامة البدن وسيطرة الثهوات ، وبالتالي الكسل والتراخي ، مما يؤدي به إلى الإسراف . r. نشأة الفرد الأولى قد تكون سبب في الإسراف ، بمعنى ان ينشأ الفرد في أسرة حالها البذخ والإسراف ، فما يكون منه سوى الاقتداء والتأسي • r. الغفلة عن طبيعة الحياة الدنيا وقد يكون السبب في الإسراف إنما هو الغفلة

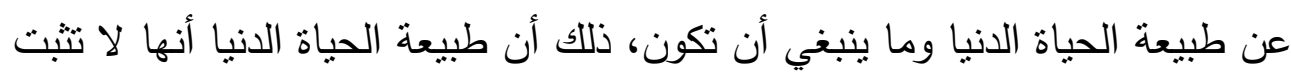
ولا تستقر على حال واحدة. والواجب يقتضي أن نضع النعمة في موضعها، وندخر ما يفيض عن حاجتتا الضرورية اليوم من مال وصحة إلى وقت آخر •

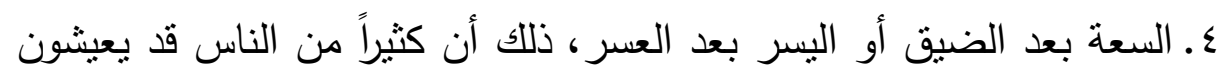
في ضيق أو حرمان أو شدة أو عسر، فإذا هم صابرون محتسبون ، وقد يحدث أن تتبدل الأحوال فتكون السعة بعد الضيق ، أو اليسر بعد العسر ، وحينئذ يصعب على هذا الصنف من الناس التوسط أو الاعتدال فينقلب على النقيض تماماً ، فيكون • الإسراف والتبذير

ه. صحبة المسرفين ذلك أن الإنسان غالباً ما يتخلق بأخلاق صاحبه وخليله . 7. حب الظهور والتباهي والثهرة أمام الناس والتعالي عليهر ، فيظهر لهم أنه سخي وجواد ، فينال ثثاءهم ومدحهم ، لذا ينفق أمواله في كل حين وبأي حال ، ولا يهمه أنه أضاع أمواله وارتكب ما حرم الله. V. المحاكاة والتقليد للأخرين حتى لا يوصف بالبخل، فينفق أمواله كيفما كان من هن أن له غير تبصر أو نظر في العاقبة التي سينتهي إليها. من صور الإسراف والتبذير في واقعنا :- للإسراف والتبذير في واقعنا المعاصر صور كثيرة منها :- 
ا.ـمن صور الإسراف والتبذير متابعة الموضة والانشغال بجنون الأزياء والاستجابة لضغوط الحملات الإعلامية الصاخبة التي تحمل كثيرا من متابعيها على الإلى • شراء ما لا يحتاجون r. من الإسراف و التبذير أن ينفق الفرد ماله فيما لا يجدي عليه نفعاً في دنياه ولا يكسبه أجراً في أخراه ، بل يكسبه في دنياه ذماً ويحمل إلى آخرته إثماً ، كإنفاقه في المحرمات وشرب الخمر وإتيان الفواحش وإعطائه السفهاء من المغنين والملهين والمساخر والمضحكين

r. ومن التبذير أن يشغل المال بفضول الدور التي لا يحتاج إلبها وعساه لا يسكنها أو يينيها لأعدائه ولخراب الدهر الذي هو قاتنائه وسالبه . ع.ومن التبذير أن يجعل المال في الفُش الوثيرة والأواني الكثيرة الفضية والذهبية . •. إنفاق المال في فضول الطعام والثراب بل ورمي الطعام والثراب في القمامة من صور الإسراف والتبذير ، والعجيب أن بعض الدول الإسلامية تبلغ نسبة فضلات

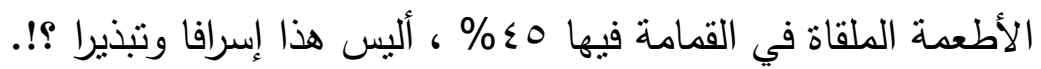
7. من صور الإسراف والتبذير ما نشاهده في المناسبات والحفلات من التباهي والتفاخر بصنع أصناف الأطعمة والحلويات . لإنرون V. من صور الإسراف والتبذير مواكبة التقنية الحديثة باقتناء كل جديد من الأجهزة وكمالياتها متتاسين الهدف الحقيقي وراء اقتتاءنا لهذه الأجهزة . ومما ذكر ابن مفلح المقدي في هذا الثأن في كتابه الآداب الشرعية الجزء الأول " وقال سليمان بن داود عليهما السلام : أُعطينا ما أُعطي الناسُ وما لم يُعطوا وعُلمنا ما عُلم الناس وما لم يعلموا ، فلم نر شيئًا أفضل من العدل في الرضا لمان والغضب والقصد في الغنى والفقر وخشية الله في السر والعلانية ".صه • ب ، وفي الجزء الثاني من كتابه " قال ابن الجوزي : ونقل أن الرشيد كان له طبيب نصراني 
حاذق ، فقال لعلي بن الحسين : ليس في كتابكم من علم الطب شيءٌ إفقال عليُّ بن الحسين وهو ابن واقد : قد جمع الله الطب في نصف آية من كتابنا ، فقال : ما هي

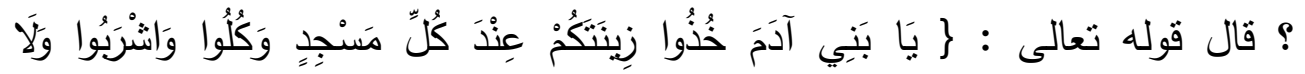

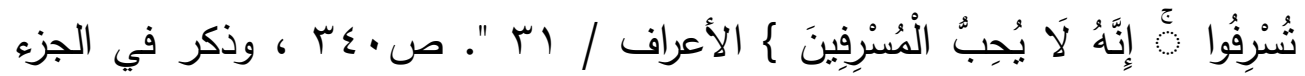
الثالث من كتابه " في التبذير قولان : احدهما إنفاق المال في غير حق الإن ، أو في غير

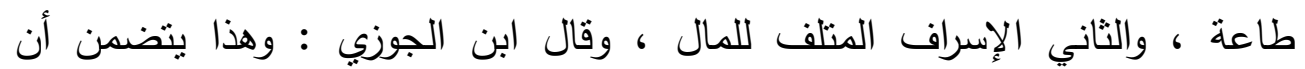
المسرف كفور للنعم ، والتبذير أن يصرفه في حرام أو في غير فائدة " ص. 19 1-

ومما سبق يظهر لنا توجيه الله سبحانه وتعالى في محكم كتابه بالبعد عن الاسراف والتبذير في المال والطعام والثراب وفي سائر الأمور ، ومع ذلك نجده

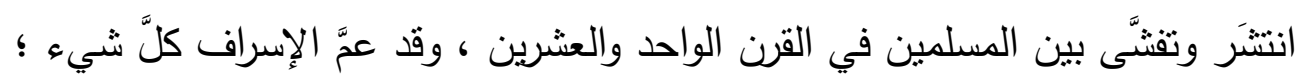
الصالح والطالح ، وهو أمر يُنذر بضررٍ شديد في الدنيا والآخرة .

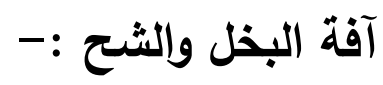

معنى البخل لغةً : " البُخْلُ ضِدُّ الكَرَمِ والجُودِ ، وقد بَخِلَ بكذا : أبي ضنَّ بما

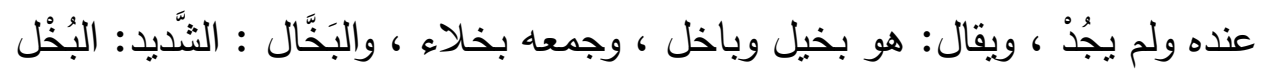

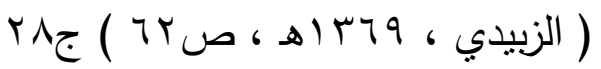

معنى البخل اصطلاحًا : البُخْلُ : " إمساك المقتتيات عمّا لا يحق حبسها عنه ".

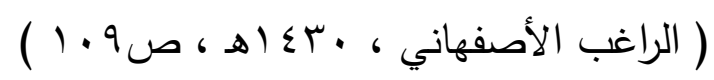

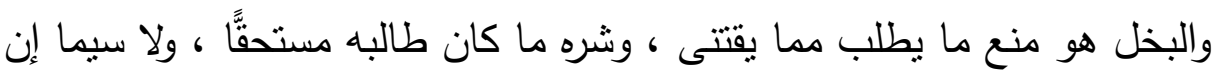

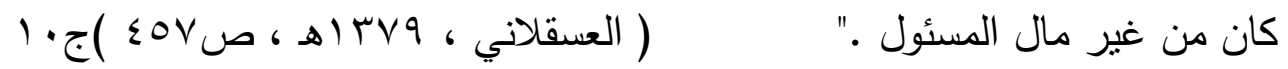

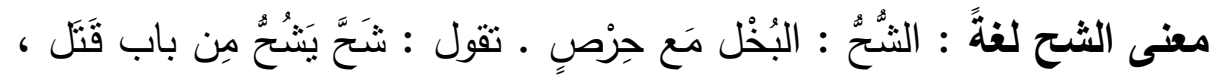

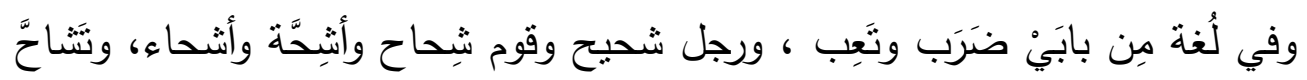

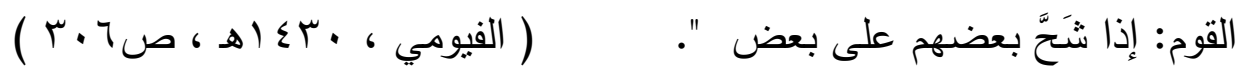


معنى الثُحِ اصطلاحًا : " الثُحُ : هو البخل بأداء الحقوق، والحرص على ما

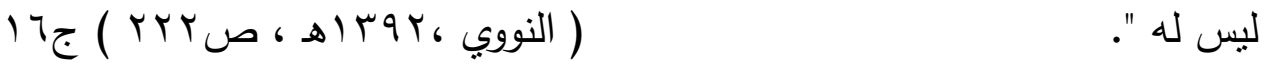

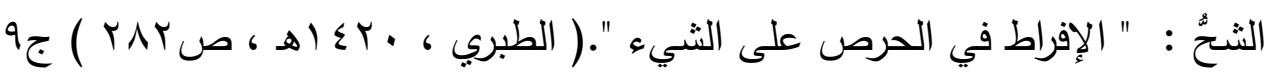

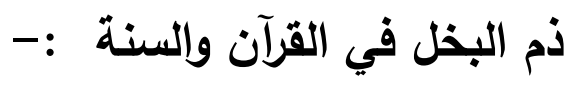

البخل رزيلة عواقبها وخيمة ، وآثارها سيئة على الإنسان في حياته وبعد مماته

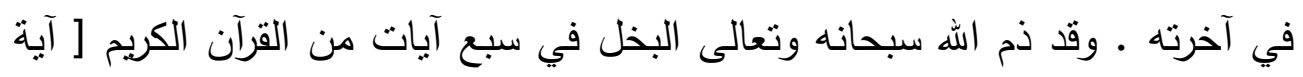

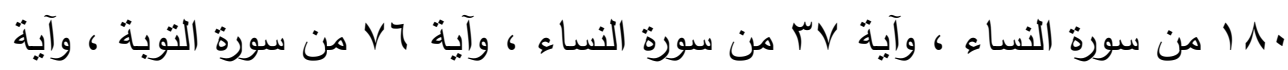

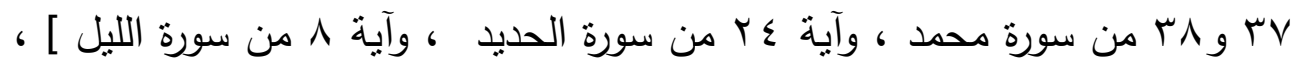

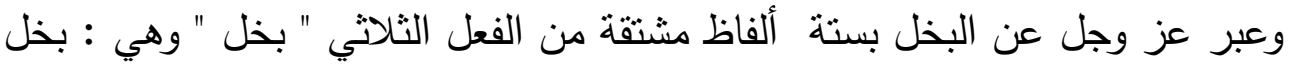

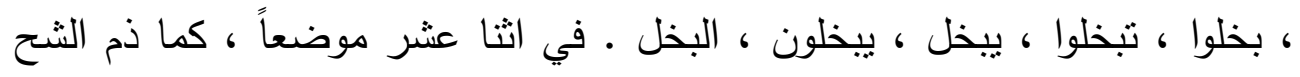

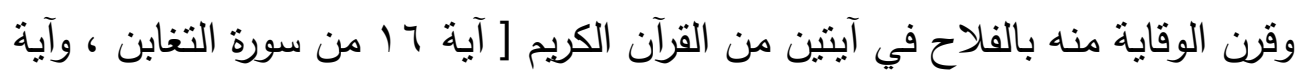

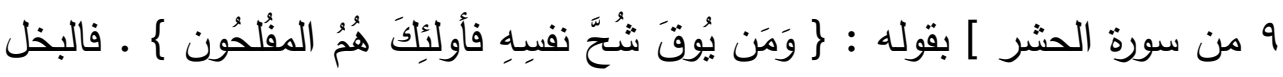
من الصفات المذمومة التي ذمها الله ورسوله ، يقول الله سبحانه وتعالى :

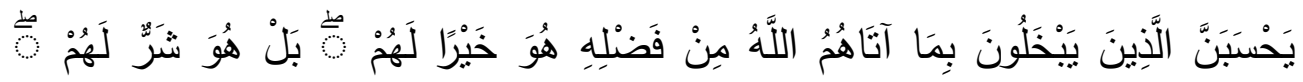

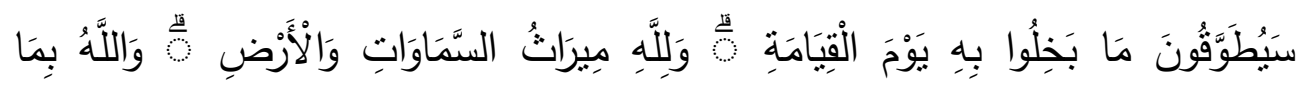

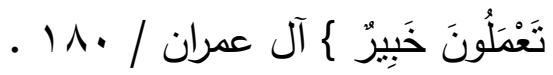

قال الثيخ عبدالرحمن السعدي رحمه اله " أبي : ولا يظن الذين ييخلون أي

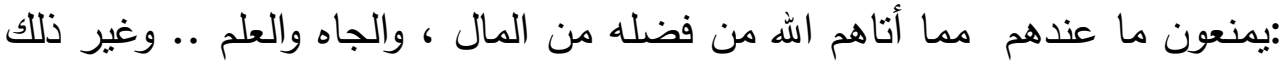
مما منحهم الله وأحسن إليهم به وأمرهم ببذل ما لا يضرهم منه لعباده ، فبخلوا بذللك

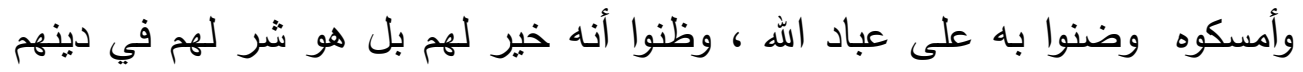

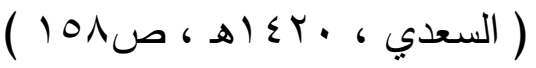

$$
\begin{aligned}
& \text { ودنياهم ، وعاجلهم وآجلهم ". }
\end{aligned}
$$

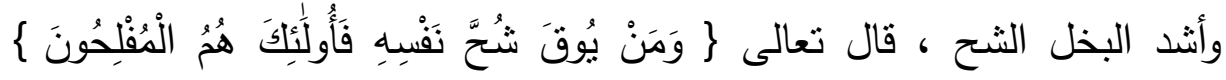
الحشر / 9 ، قال الرازي : الثخح هو البخل مع حرص لـ وروى مسلم في صحيحه 


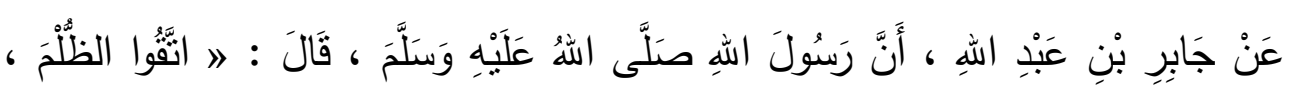

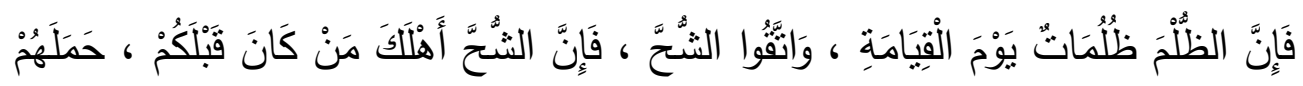

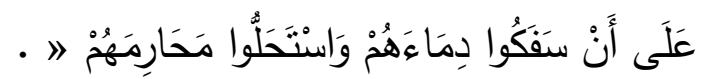

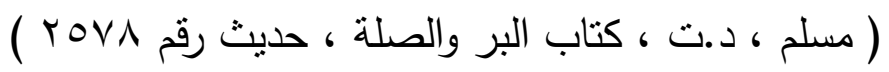

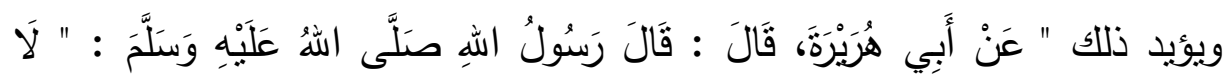

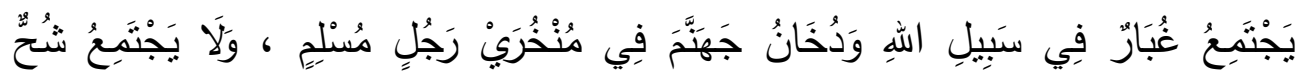

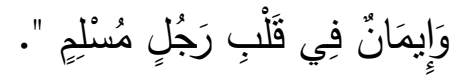

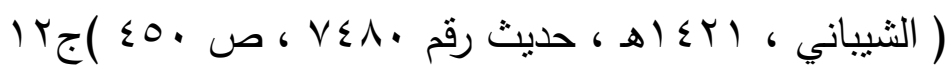

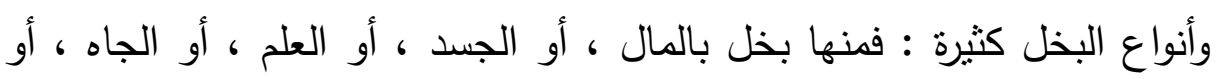

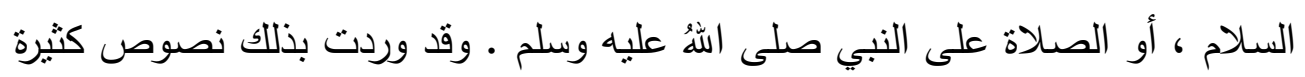

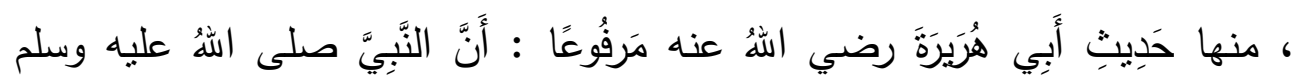

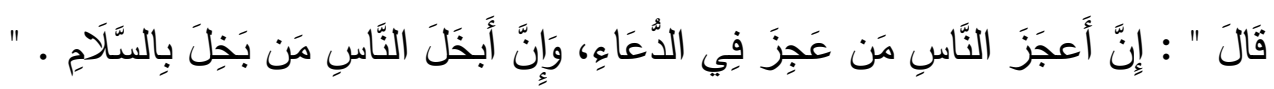

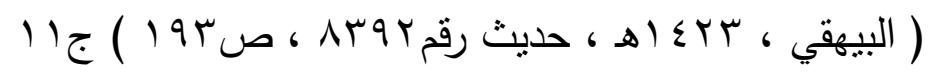

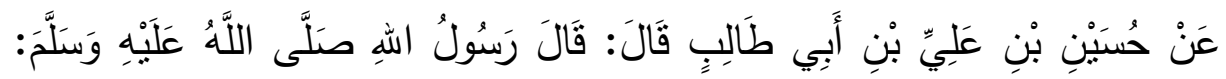

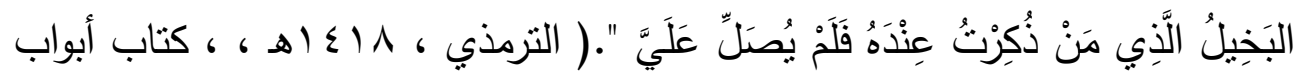

$$
\text { الدوجات البخل ، حديث رقم }
$$

ا ـ البخل على النفس :- " والبخل والسخاء درجات ، وأثند درجات البخل أن الن البحل

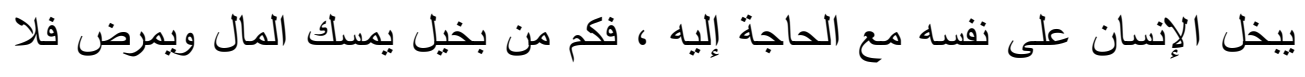

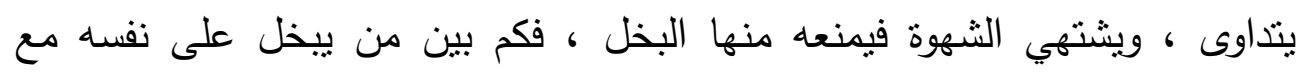

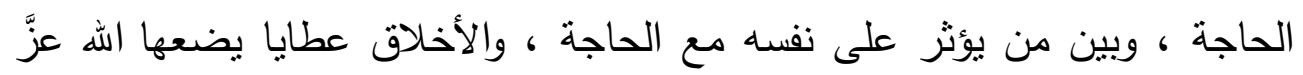

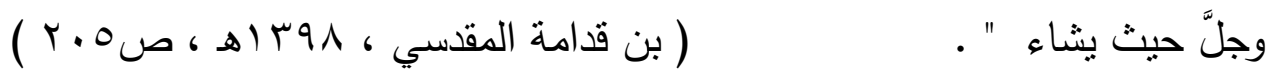


r. البخل بالواجبات ، والفرائض ، مثل البخل بالزكاة ، أو النفقة على الأهل ، أو

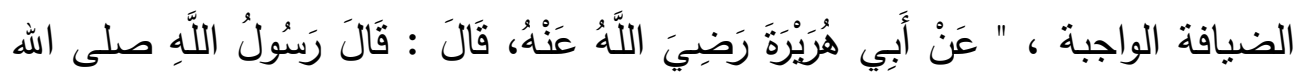

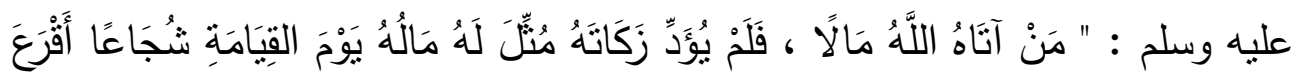

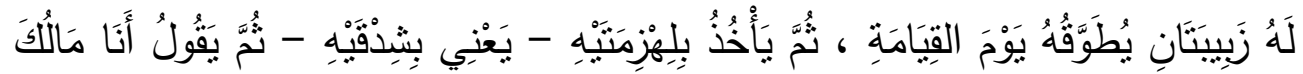

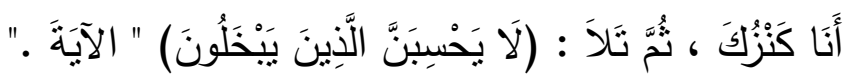

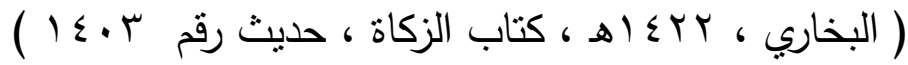

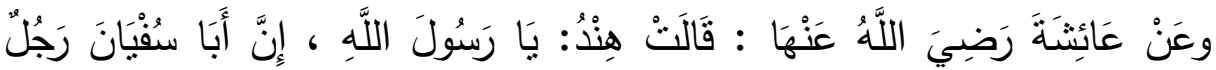

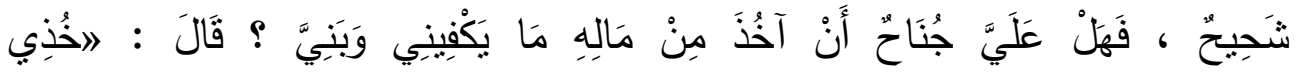

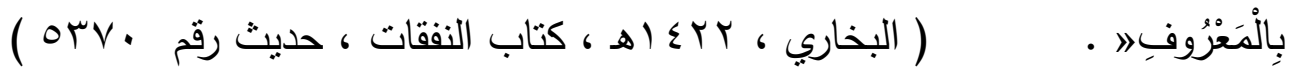

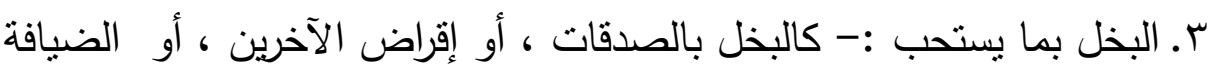

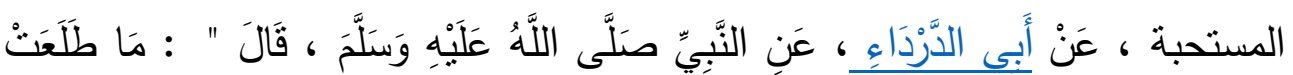

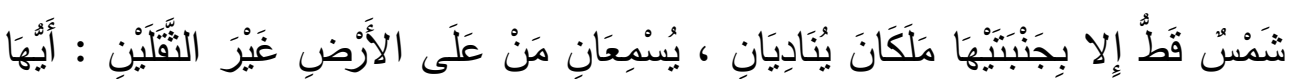

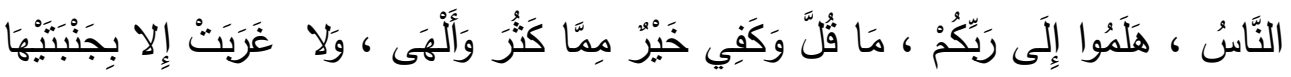

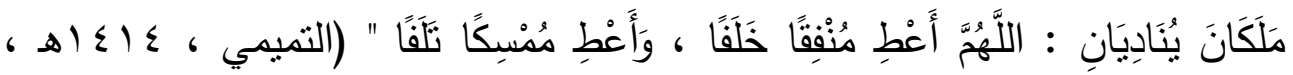

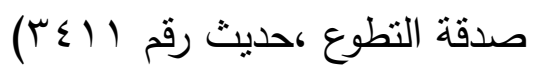

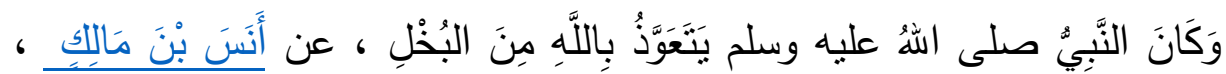

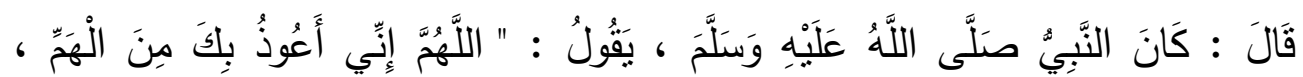

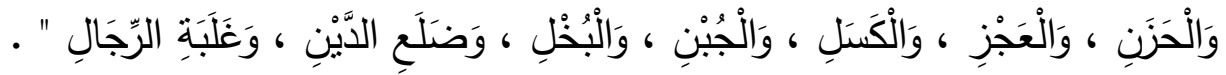

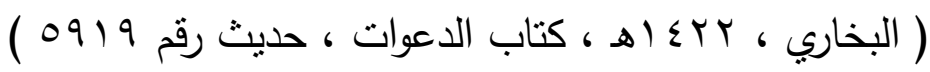

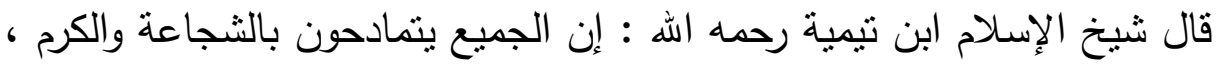
حتى إن ذللك عامة ما تمدح به الثعراء ممدوحيهم في شعرهم ، وكذلك ينذامون بالبخل والجبن ، ثم قال : ولما كان صلاح بني آدم لا يتم في دينهم ودنياهم إلا بالثجاعة ، والكرم ، بين اله سبحانه أنه من نولى عنه بترك الجهاد بنفسه أبدل الله 
باه من يقوم بذلك ، ومن نولى عنه بإنفاق ماله أبدل الله به من يقوم بذلك ، فقال :

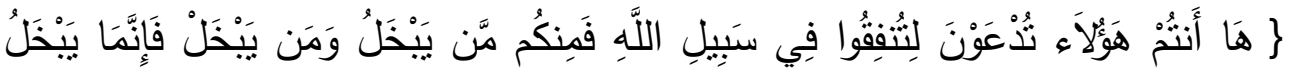

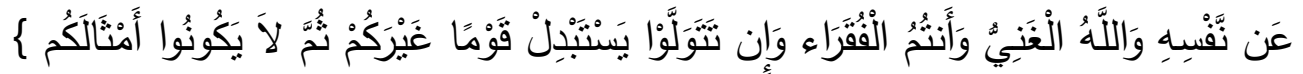

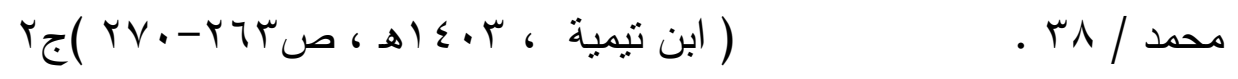

ومما يدل على مقت البخل وأنه مما ينافي مكارم الأخلاق ، عَنْ مُحَمَّدِ بْنِ جُبَيَرِ

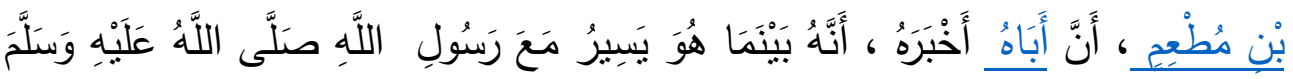

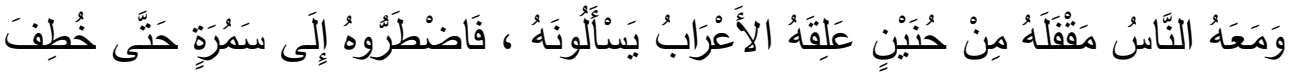

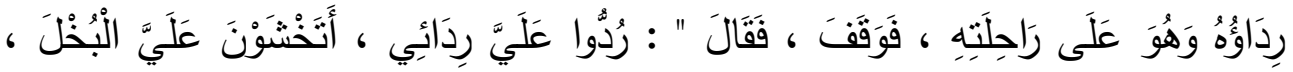

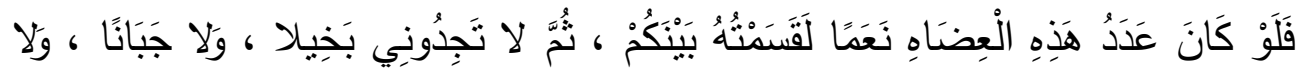

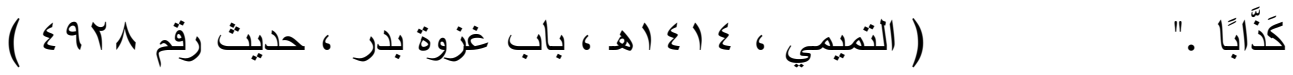
قال ابن القيّم رحمه الهه " : الجبن والبخل قرينان ، فإن عدم النفع منه إن كان ببدنه فهو الجبن ، وإن كان بماله فهو البخل ".

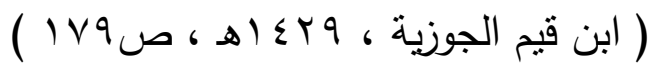
وينتج عن البخل من الأخلاق المذمومة الكثير، وإن كان ذريعة إلى كل مذمة ومن الأخلاق المذمومة الناتجة عن البخل : الحرص ، والثره ، وسوء الظن ، ومنع

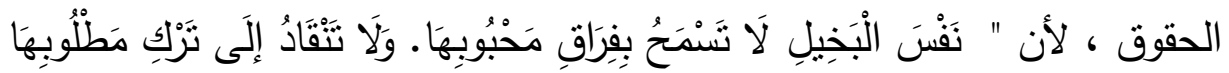

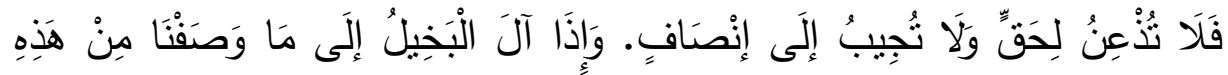

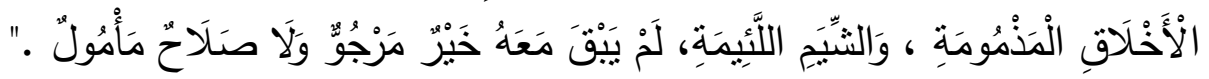

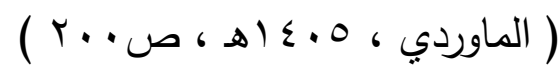

ومما ذكره ابن مفلح المقدي في كتابه الآداب الثرعية الجزء الثالث في هذا الثنأن : " في حد البخل أقوالاً : أحدها منع الزكاة ، فمن أداها خرج من جواز إطلاق البخل عليه ، والثاني منع الواجبات من الزكاة والنفقة ، والثالث فعل الواجبات

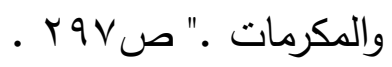


وقال عمر : قسم رسول الله صلى الله عليه وسلم قسماً فقلت : يا رسول الهه لغير هؤلاء أحق به منهم ، قال : (( إنهم خيروني بين أن يسألوني بالفحش ، أو يُبخلوني ،

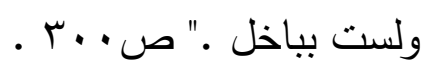

" قال أعرابي : عجبًا للبخيل المتعجل للفقر الذي منه هرب ، والمؤخر للسعة التي إياها طلب ، ولعله يموت بين هربه وطلبه ، فيكون عيشه في الدنيا عيش الفقراء وحسابه في الآخرة حساب الأغنياء ، مع أنك لم نز بخيلًا إلا غيره أسعد بمالِِهِ منه وله

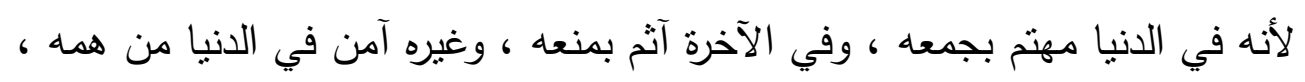

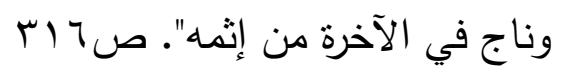

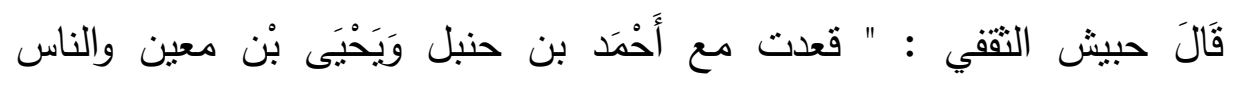
متوافرون فأجمعوا أنهم لا يعرفون رجلا صالحًا بخيلا."( أبي يعلى الفراء البغدادي

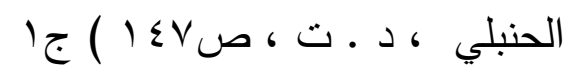
آفة الزنا :-

الزنا لغةًَ : " زنَى/ زنَى بـ يَزنِي، ازْنِ ، زِنَى وزِناءً ، فهو زانٍ ، والمفعول مزنيّ به

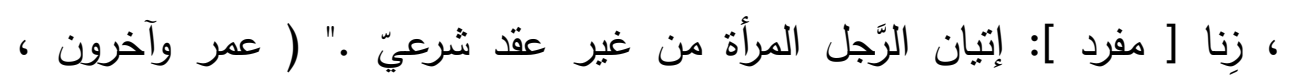
r تعريف الزنا اصطلاحاً : " هو الوطء في قُبّل خالٍ عن ملك وشبه ".

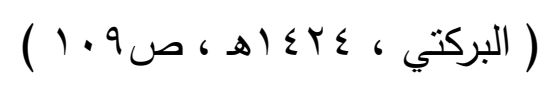

وهو من الأفعال التي تكرهها الفطرة الإنسانيّة السويّة ، كما أنه مُحرَّم في هابي الديانات السماوية ، لمفاسده ، ومضارّة التي يتسبّب بها على الصعيدين : الفرديّ ، والجماعيّ • وتعتبر جريمة الزنا من كبائر الذنوب والمعاصي التي حرّمها الله تعالى على العباد ، وكما ذكرها رسول الله صلى الله عليه وسلم من ضمن السبع الموبقات أي السبع الكبائر التي تهلك صاحبها وتقرّبه من عذاب الله تعالى ، وقد وضع الله سبحانه وتعالى لجريمة الزنا عقوبة وحدّاً وهو الرجم حتى الموت للزاني المحصن 
والجلد مئة جلدة مع تغريب سنة للزاني غير المحصن ، وقد وضع اله تلك العقوبة لحفظ الأعراض والناس ، فالتساهل في هذه المسألة يؤدّي إلى شيوع الفاحشة في المجتمع المسلم ، كما حارب الإسـام بتشريعاته وتوجيهاته كل مقدمات الزنا كالنظرة والاختلاط المحرم بين الجنسين ، وبالتالي أعطى الإسلام للمسلم عناصر وقاية تحميه من الوقوع في هذه الجريمة التي تسيء للمجتمع بأكمله .

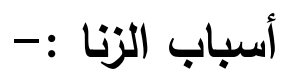

ا. عدم وجود الحواجز بين الرجل والمرأة في المجتمع ، فالإسلام حين حرّم الاختلاط حرّمه بسبب ما يترتبّ عليه من مفاسد جمّة ، فما خلا رجل بامرأة إلا كان ثالثهما الثيطان ، وقد لام الناس قديماً حرّة زنت وتعجّبوا من فعلها وسبب ارتكابها لهذا الجريمة ، فقالت زنيت بسبب قرب الوساد وطول السواد ، أي بسبب قرب الرجل

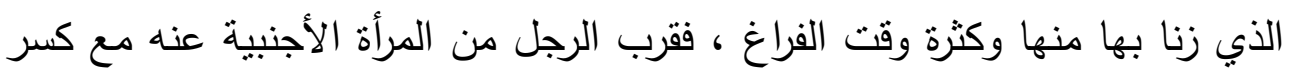
الحواجز فيما بينهما يؤديّ بلا شك إلى ارتكاب هذه الجريمة ، وما نشهده في عصرنا الحاضر من كثرة الاختلاط بين الجنسين لهو طامّة كبرى أدّت إلى مفاسد عظيمة . r. عدم تزويج الثباب وتركهم يهيمون في الطرقات بدون شغل لهو مفسدة كبرى تؤدي إلى جريمة الزنا ، فتيّسير سبل الزواج أمام الثباب يؤدّي إلى تحصينهم من هذه

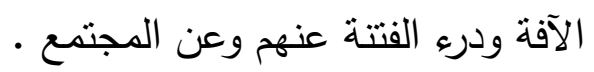
r. تسهم الفضائيات والقنوات التلفزيونية التي تتفنّن بعرض العرّي والرذيلة وتقتحم بمشاهدها بيوتتا في نشر الرذيلة والفاحشة والوقوع في الزنا ـ

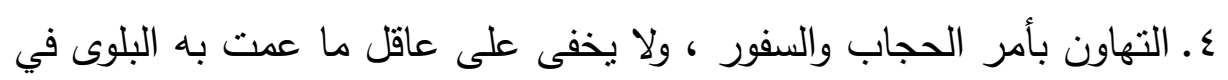
كثير من بلاد المسلمين من تبرج كثير من النساء وعدم التزامهن بالحجاب ، ولا شك

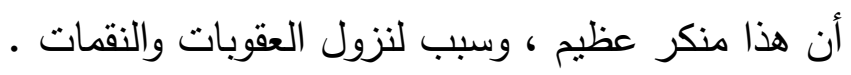
ه. اطلاق البصر إلى النساء لقد أمر الله سبحانه تعالى نبيه أن يأمر المؤمنين بغض أبصارهم وحفظ فروجهم وأن يعلمهر أنه مشاهد لأعمالهم مطلع عليها يعلم 
خائنة الأعين وما تخفي الصدور ، ولما كان مبدأ ذلك من قبل البصر جعل الأمر بغضه مقدماً على حفظ الفرج ، فإن الحوادث مبدأها من النظر ، كما أن معظم النار

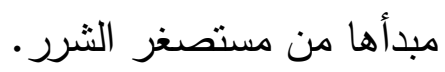

ومن أعظم أسباب الوقاية من الوقوع في هذه الفاحشة صدق الاعتصام بالها

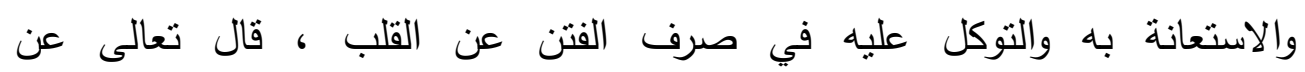

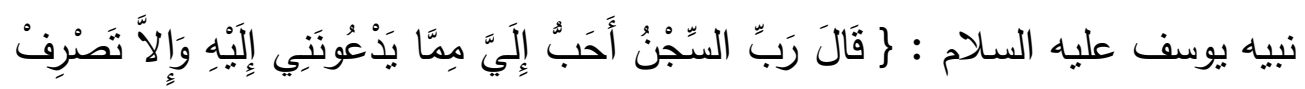

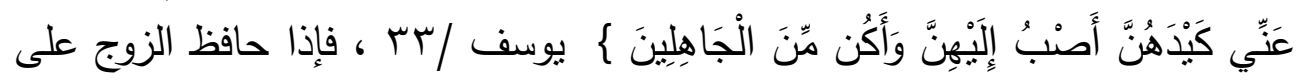

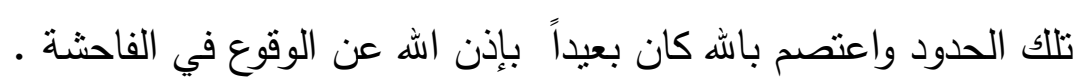

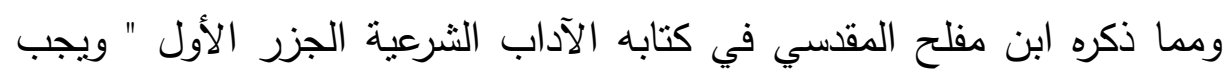

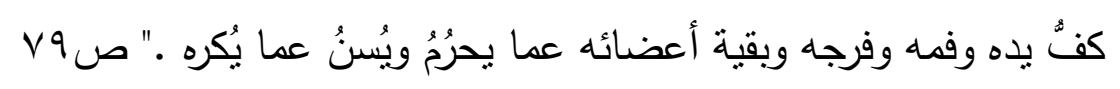

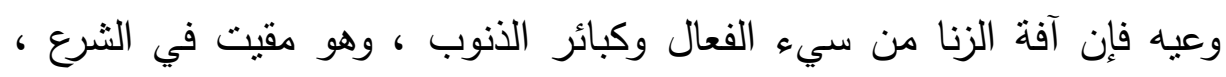

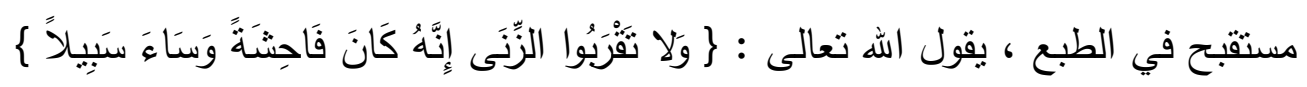

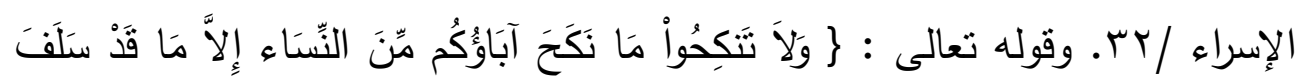

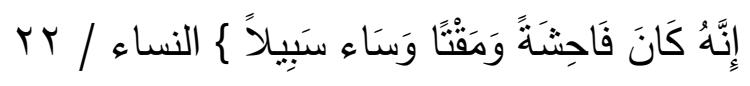

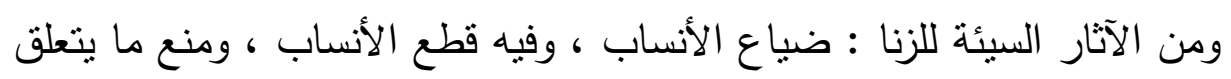

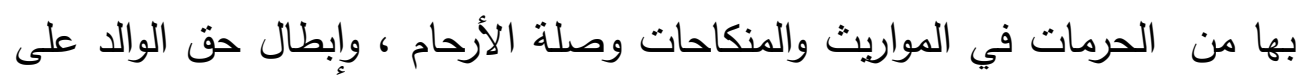

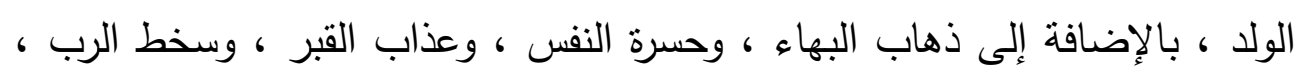

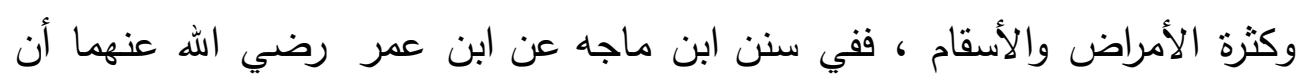

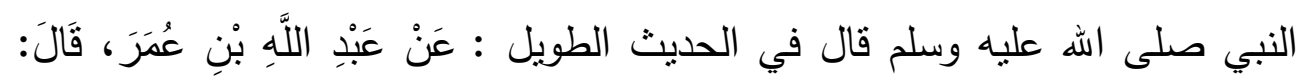

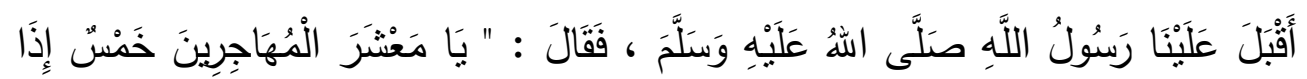

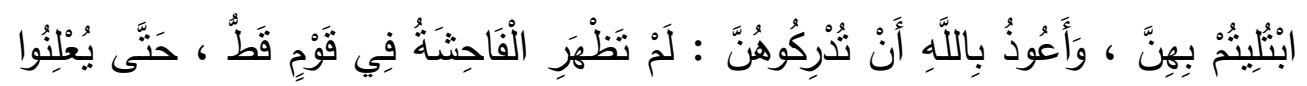

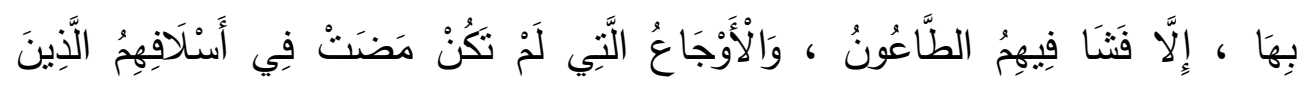

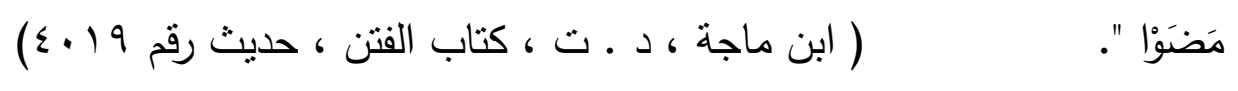


وأوضتح دليل على ذلك في زماننا انتشار الإيدز حفظنا الله والمسلمين أجمعين .

آفة الكبر وحب الثهرة :-

تعريف الكِبر في اللغة :- كبِر يقصد بها " عظمة وتجبُر وترفُّع عن الانقياد ،

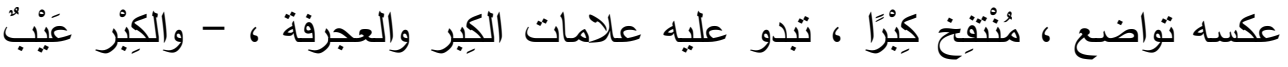

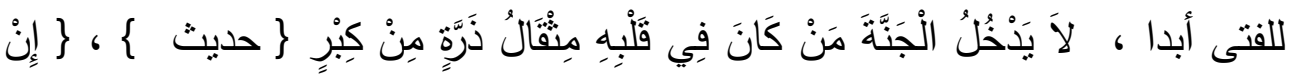

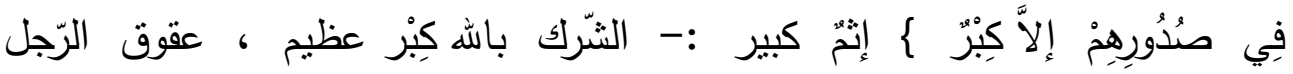

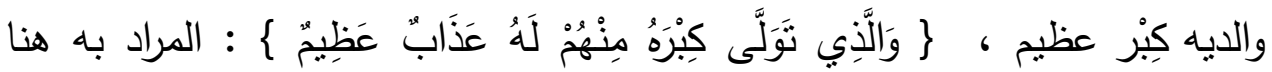

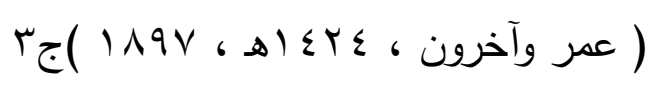$$
\text { - حديث الإفلك: }
$$

تعريف الكبر في الاصطلاح :- إظهار العامل إعجابه بنفسه بصورة تجعله يحتقر الآخرين في أنفسهر ، وبنال من ذواتهم ، ويترفع عن قبول الحق منهم جاء في

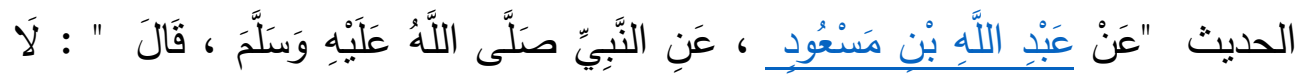

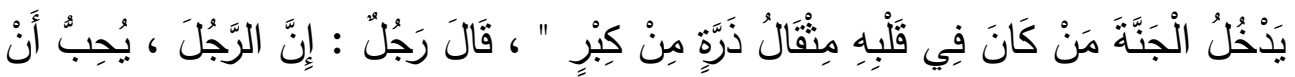

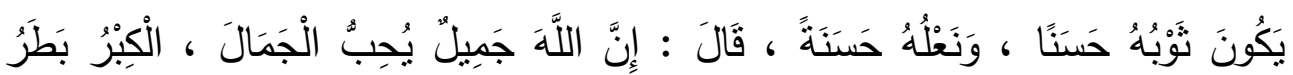

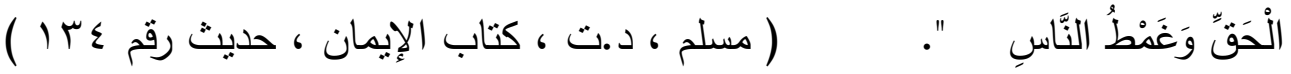
فالكبر ، التكبر، الغطرسة ، التعاظم كلها تحمل نفس المعنى وهو آثز من آثار العجب والافتراء من قلب قد أمتلأ بالجهل و والظلا ترحلت منه العبودية ، ونزل عليه المقت فنظره إلى الناس شذر ومشيه بينهم تبختز ومعاملته لهم معاملة الاستئنار لا الإيثار ولا الإنصاف ولا يرى لأحد عليه حقا ويرى حقوقه على الناس ولا يرى فضلهم عليه

تعريف الشهرة في اللغة :- شُهْرة [ مفرد ] : ج شُهُرات (لغير المصدر) وشُهُرات ( لغير المصدر) لكون اسم أو شخص أو شيء معروفًا لدى النَّاس معرفة واسعة ، صيت وسُععة " طبَّتَ شهرتُه الآفاقَ ، له شُهُرة واسعة بين النَّاس " و شهرة

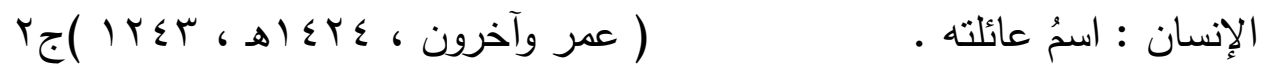


تعريف الثهرة في الاصطلاح :- الثهرة هي الصيت وحب الظهور ، وتسليط

الأضواء عليه ، وحب الثهرة مرض موجودٌ في نفوس البعض نسأل الله العافية ، وهناك العديد من أنواع الثهرة الدنيوية الدذمومة القبيحة الدضيعة للوقت الصارفة

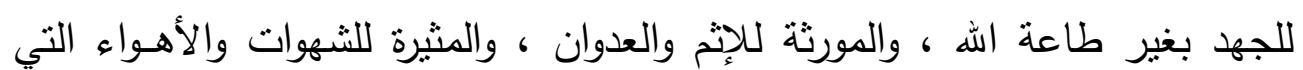
تـؤدي إلى إضلال الناس ( كثهرة الفسقة من الممتلين والمطربين الذين يحبون

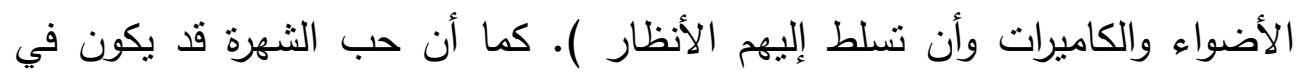

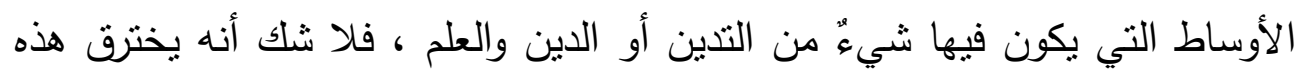

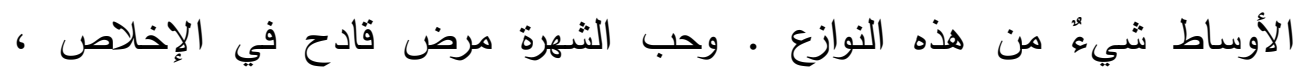

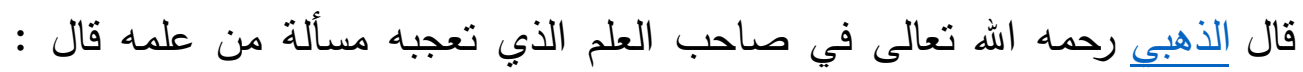

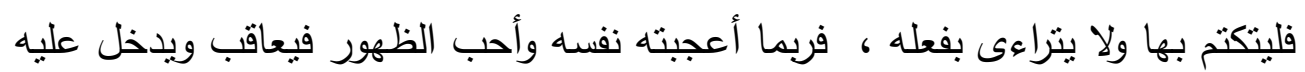

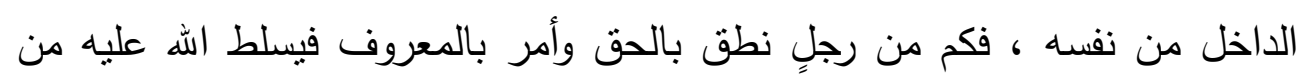
يؤَذيه .

ومما ذكره ابن مفلح المقسي في كنابه الآداب الثرعية الجزء الثاني في هذا الثأن " وروى الخلال عن الفضيل قال :علامة الزهد في الناس إذا لم يحبَّ ثناء

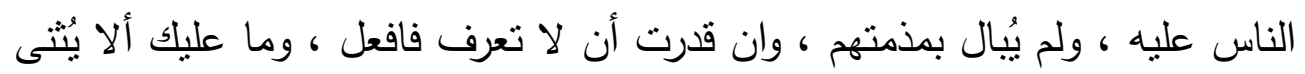

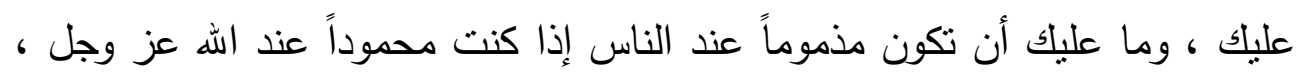

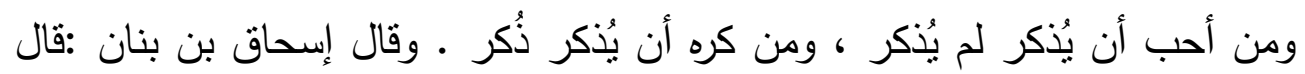

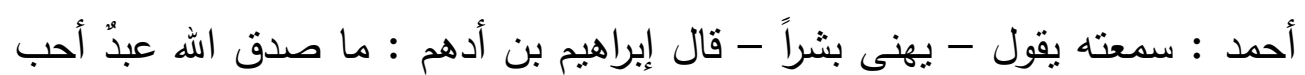

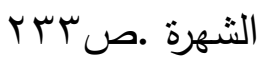

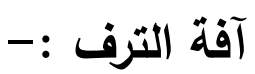

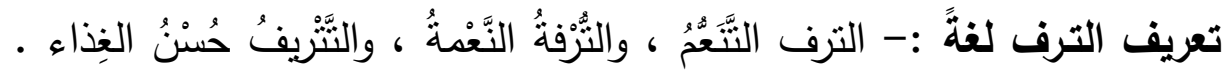

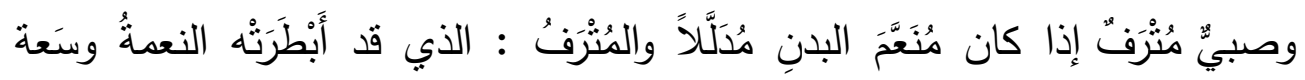
العيّش 


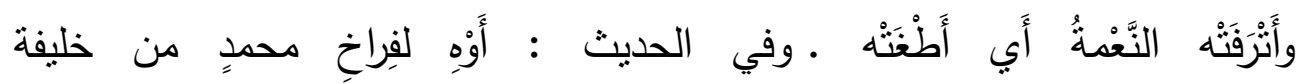

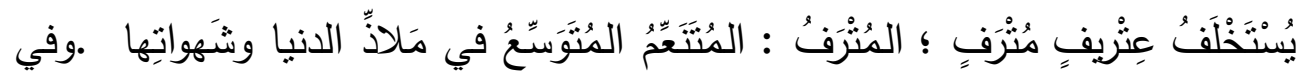

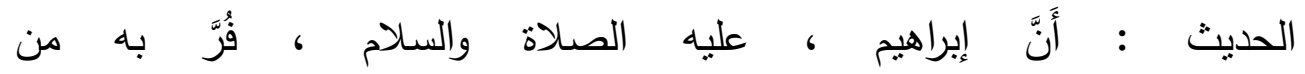

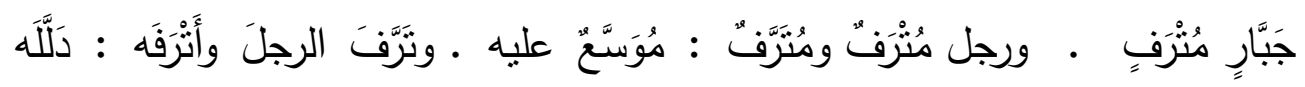

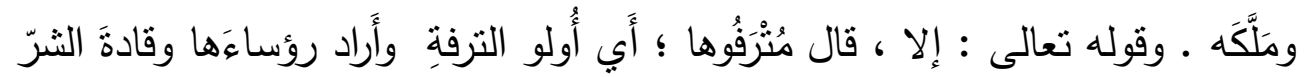

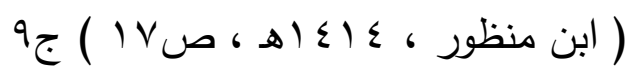
من من تعريف الترف في الاصطلاح :- هو مجاوزة الحد في الاعتدال ، والإكثار من النعم التي يحصل بها الترف فالمترفون إذن أبطرتهم النعمة وسعة العيش وهم حريصون على الزيادة في أحوالهم وعوائدهم والساعون إلى بلوغ الغاية في حاجات النفس الحسية من المآكل والمشارب والمساكن والمراكب.

والتزف قائم على الغنى ومبني عليه لكنه ليس بلازم لله فكم من غني بخيل يعيش حياته حياة البؤس والعوز ، وكم من فقير حرص على تحصيل النعم وتحصبل الثهوات واللذات من كل طريق يعيش بأكثر من دخله فتركبه الديون . لقد ورد ذكر الترف في القرآن الكريم في ثمانية مواضع كلها في الذم والتحذير

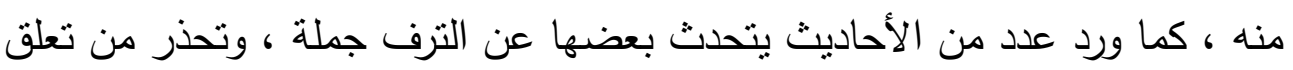
القلب به وبلاء الإنسان بالانغماس في متع الحياة وملذاتها ـ والبعض الآخر من هذه النصوص ينهى عن مظاهر الترف ويحث على تركه والانصراف عنه إلى ما هو خير في الدارين ، فالترف آفة من أعظم الآفات التي تصيب الأفراد والجماعات ، و هو لهو

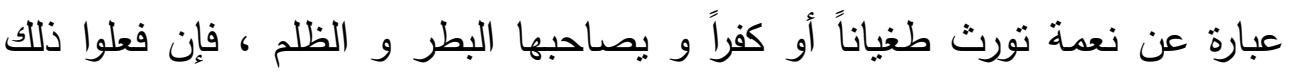

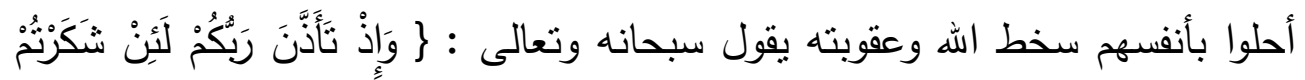

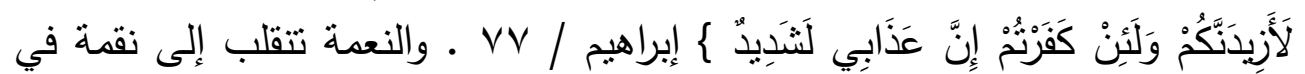

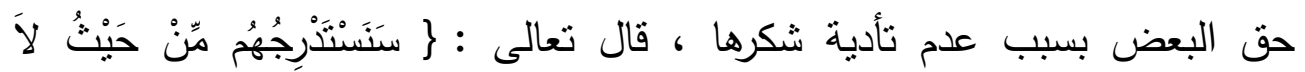

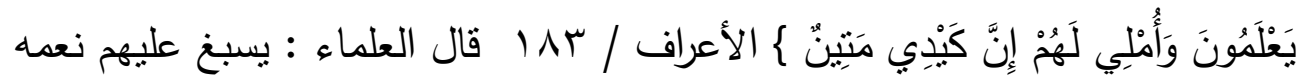


و يمنعهم شكرها ، و قالوا أيضا : كلما أحدثوا ذنباً أحدث لهم نعمة فيزدادون بها أشراً

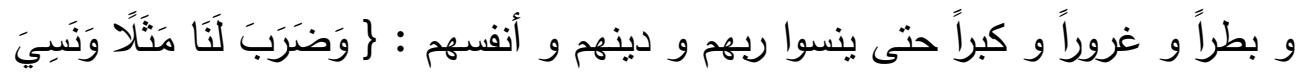

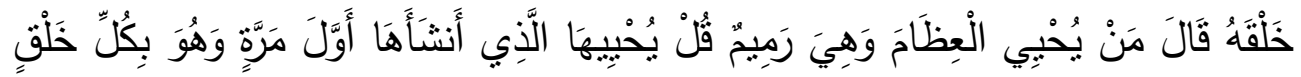
عَليمٌ \{ يس / VA - VA ـ فالمال و السلطان و الجاهو و الصحة و القوة من نعم الله

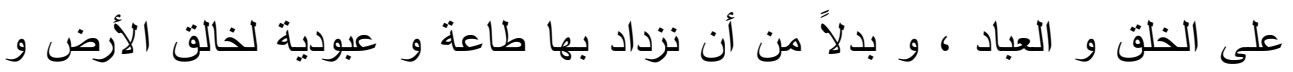

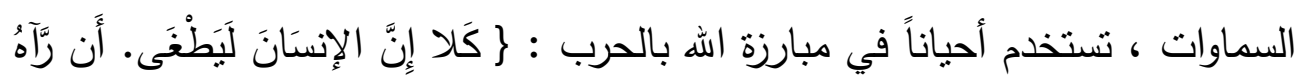

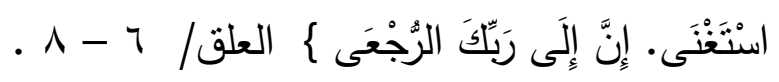

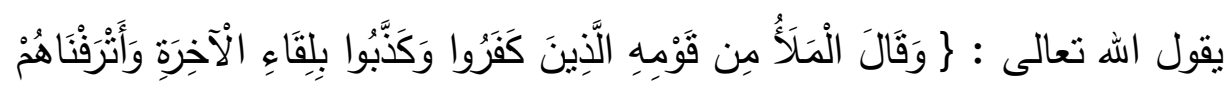

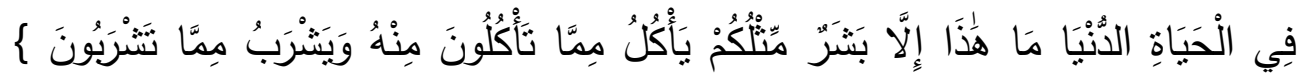
المؤمنون / سب ـ " يقول تعالى ذكره : وقالت الأشراف من قوم الرسول الذي أرسلنا بعد نوح ، وعَنَى بالرسول في هذا الموضع : صالحًا، وبقومه: ثمود ـالََّّنَ كَفَرُوا

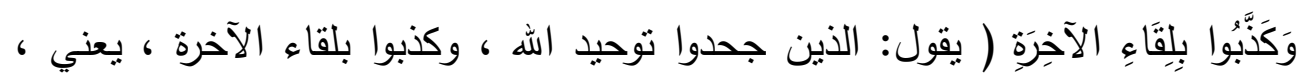

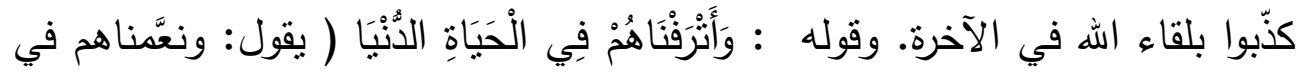
حياتهم الدنبا بما وسنَعنا عليهح من المعاش ، وبسطنا لهم من الرزق، حتى بَطِرُوا

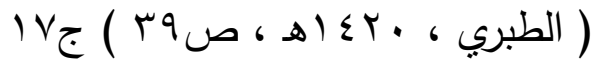

$$
\begin{aligned}
& \text { وعَتوا على ربهم ، وكفروا ." }
\end{aligned}
$$

فالنعومة والترف في الدنيا بالنسبة لعذاب الآخرة ليست بشيء ولذلك أخبرنا النبي

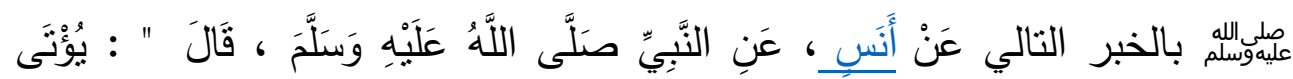

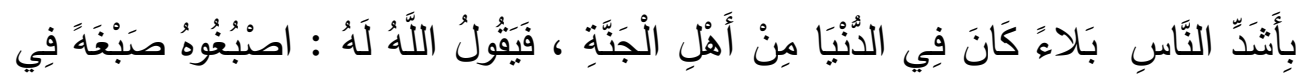

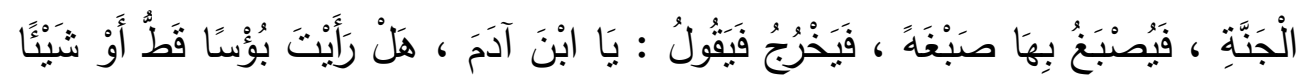

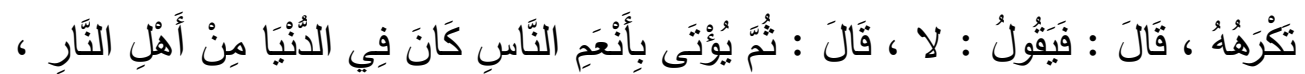

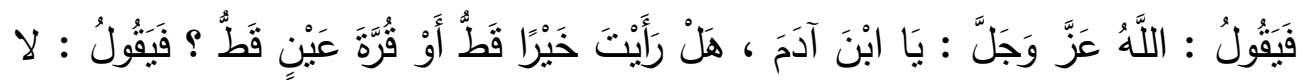

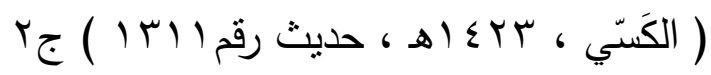
وَعِنَزتَكَ. 
إذن كل هذا الترف في الحياة الدنيا يوم القيامة لا شيء ـ عَنْ أَبِي جَعْفرٍ مُحَمَّدِ

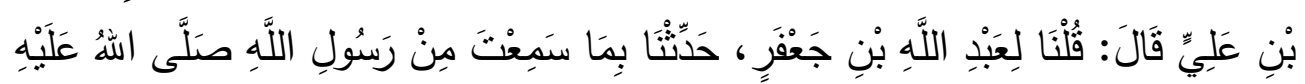

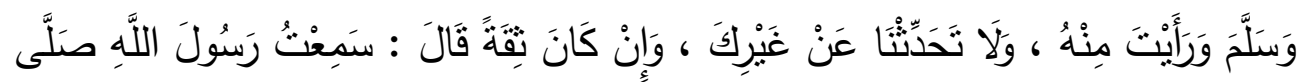

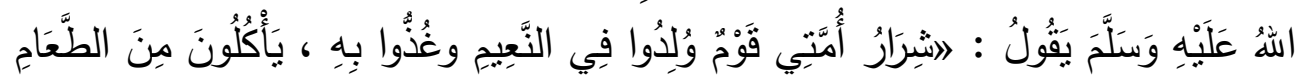

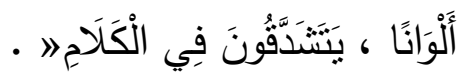

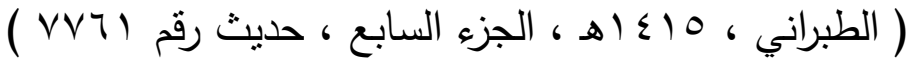

وفي ذلك دليل على ذم الترف والنعومة والانغماس في الملذات .

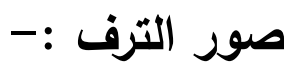

أولاً : المغالاة في المآكل والمشارب :- أهل الترف تجدهم يغالون في الأكل والشرب فتجدهم لا يأكلون من الطعام ولا يشربون من الشراب إلا أغلاه ثمناً ، ما يا

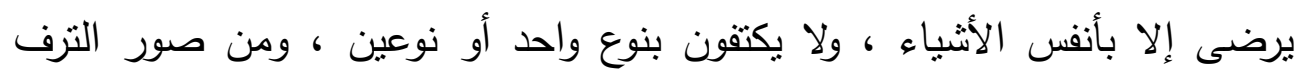
الأواني التي يأكلون فيها والأماكن التي يرتادونها للمآكل والمشارب فهم يأكلون ويشربون في أواني تباع بأغلى الأثمان لا لشيء إلا لأنها ماركة معينة . ثانياً :- المغالاة في اللباس :- فبعض الناس يثترون الملابس بأثمان باهظة ، ومنها المغالاة في لباس الأفراح والمناسبات ثالثاً :- المغالاة في الكماليات :- كاكسسوارات الجوالات ، والساعات ،

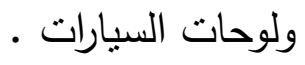

رابعاً :- المغالاة في أثاث المنزل :- فنجد بعض الأسر تقوم بتغير أثاثها كل ستة أشهر وبعضهم كل سنة وبعضهم كل ثناث سنوات وبعضهم كل خمسة بحسب القدرات المالية ـ وأما ما يحدث في بناء المنازل من الترف فنشيء لا يعلمه إلا الله . خامساً :الاهتمام المبالغ بالجسد : - لا يخرج لحرارة ولا برودة ، استعمال الأدهان والكريمات حتى صارت أجساد كثير من الرجال لا تختلف كثيراً عن أجساد النساء 
وقبل أن يخرج من البيت يقف أمام المرآة فترة طويلة يصلح هندامه ويبقى في تضبيط

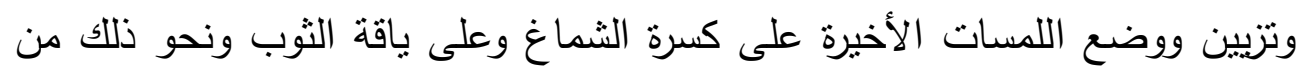

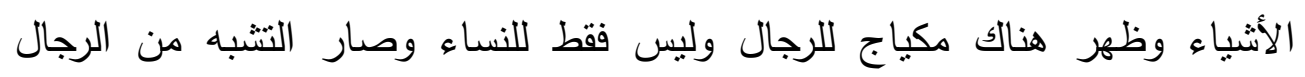
بالنساء ، هناك إسراف عجيب في مستحضرات التجميل وتعتبر سوق المستحضرات والعطورات من أعلى معدلات الاستهلاك في العالم .

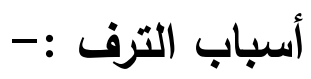

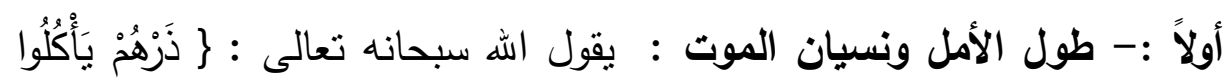

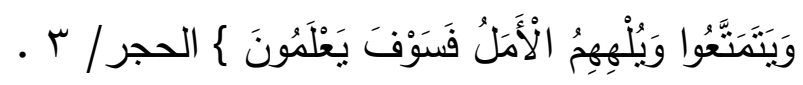

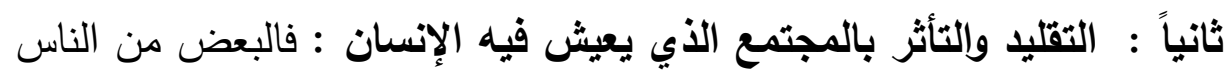

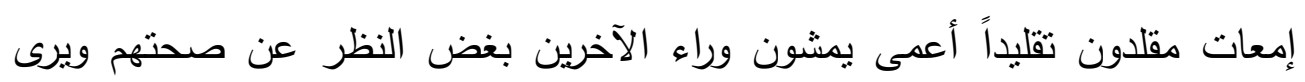

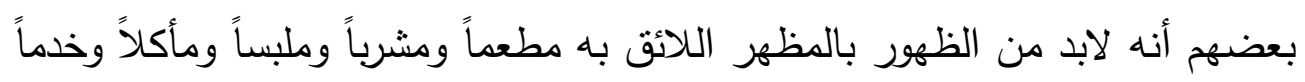

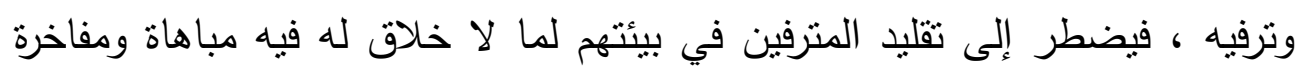

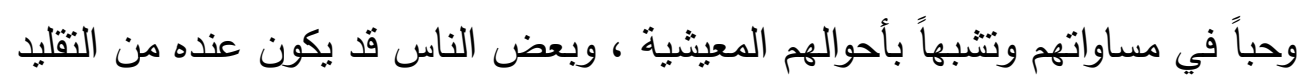
ما يجعله يستدين ليشابه هؤلاء المترفين .

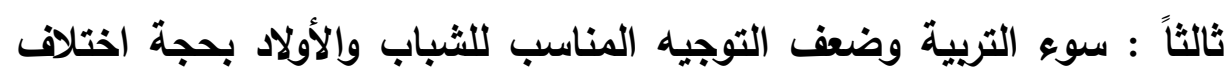
الزمان والتطور ومجاراة الأقران .

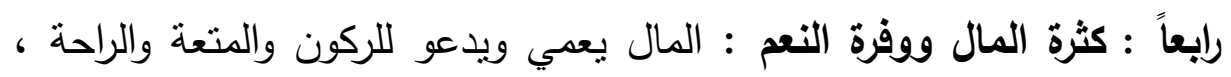

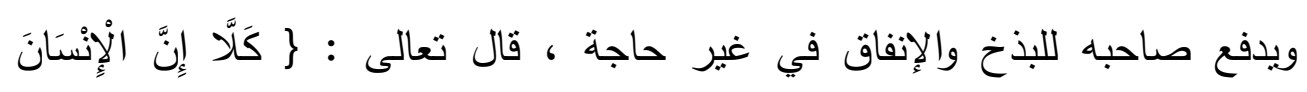

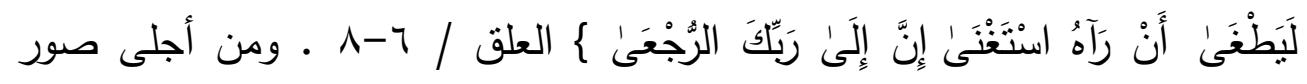

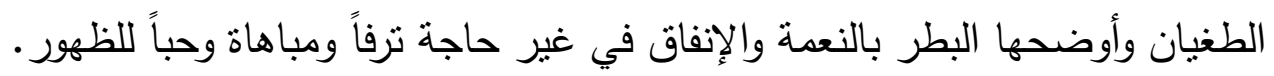

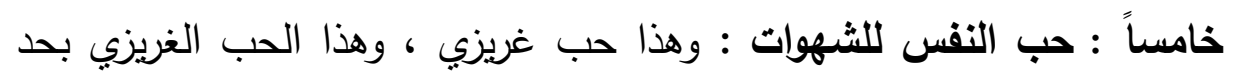

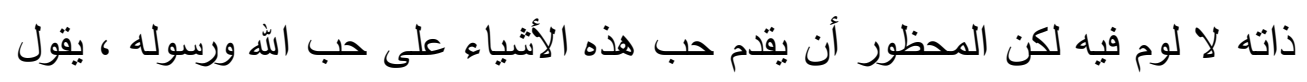




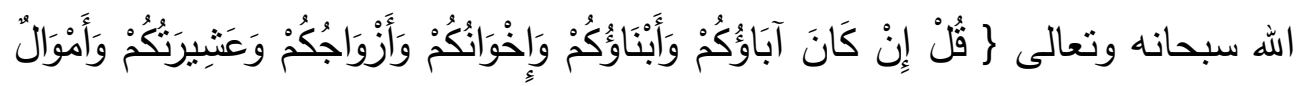

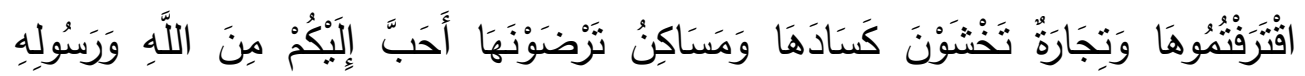

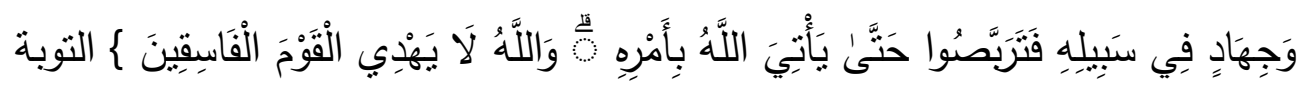

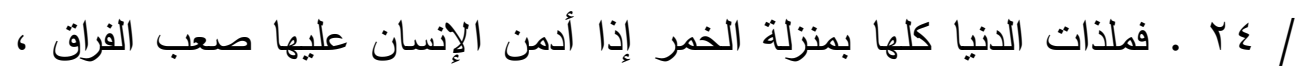

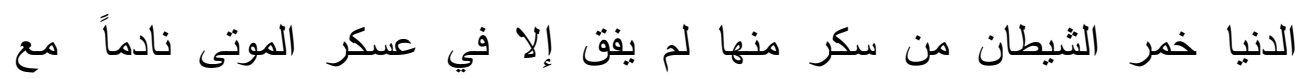

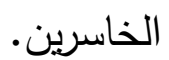

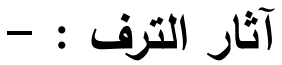

أولا : تعبيد القلب لغير الله : فالقلب يجب أن يكون عبداً لله وحده معبداً له لا لا

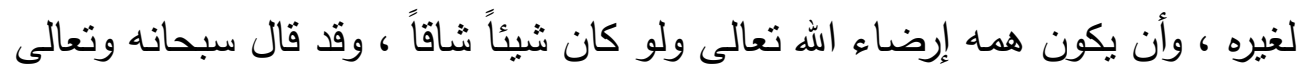

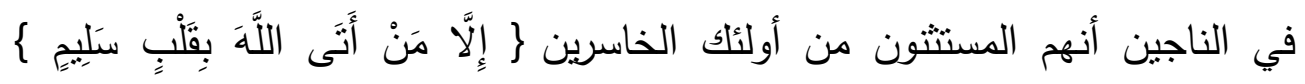

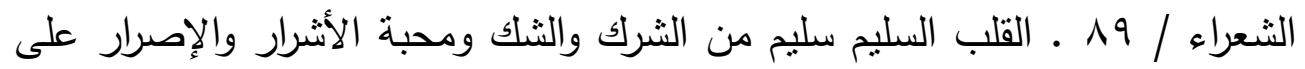

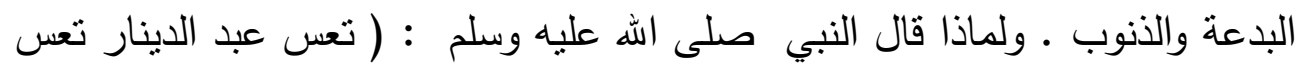

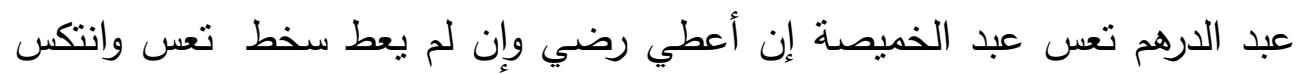

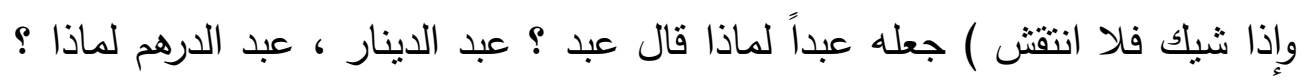

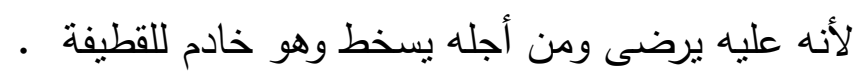

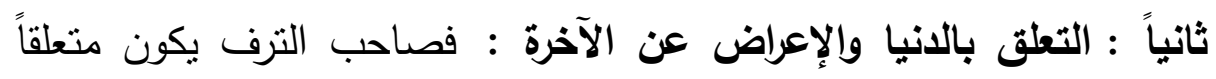

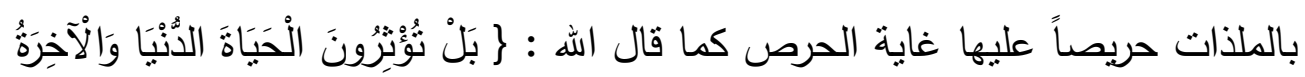

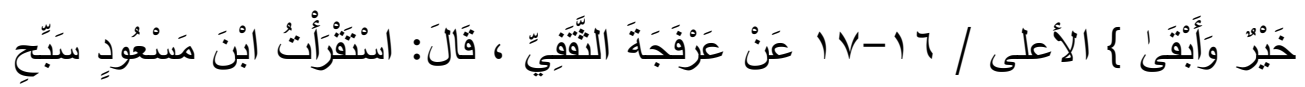

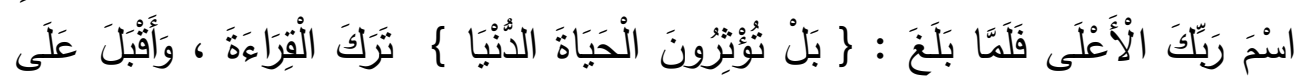

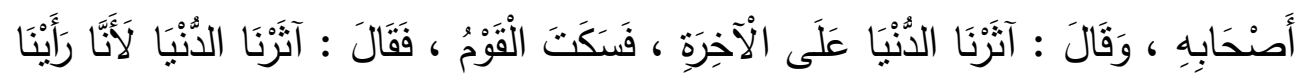

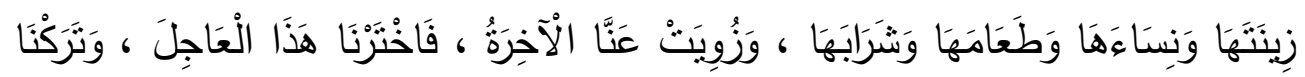

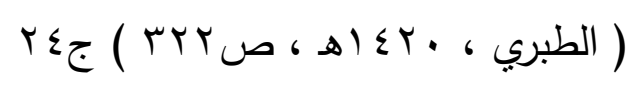


فاذا زهدت القلوب في موائد الدنيا قعدت على موائد الآخرة بين أهل تلك الدعوة ، وإذا رضيت بموائد الدنيا فاتتها تلك الموائد على موائد الآخرة .

ثالثاً : انشغال القلب بما بحقق الإنسان من الترف : فبعض الناس إذا لم يجد ما يروقه من أنواع الترف يبقى قلقاً مضطرباً حتى يحصل ما يريد فيبقى هكذا دائماً

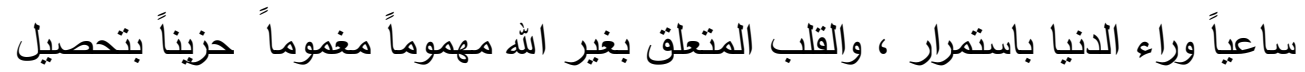
الملذات والثهوات وهكذا يأسى على ما فاته ويفرح بما آتاه فرح مطغي وليس فرح مشروع ، ولقد قال الرسول صلى الله عليه وسلم : " مَنْ كَانَتِ الأُنْبَا هَمَّهُ ، فَرَّقَ

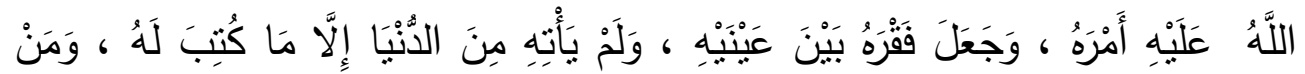

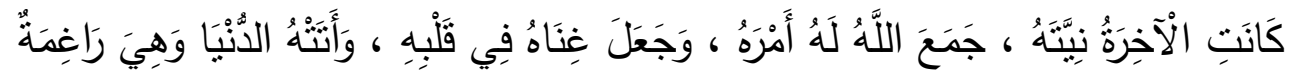

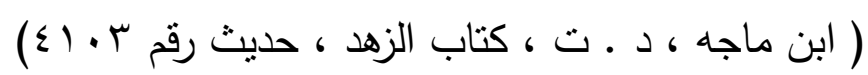

رابعاً : يذهب بالإنسان إلى بعض الأمراض : الكبر والتباهي والتفاخر والعجب ، دان

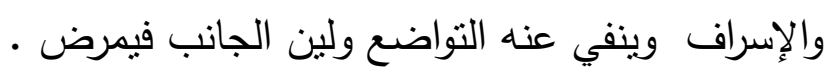
خامساً : استهلاك الأوقات : إذا أحد اراد أن يذهب ينقب في متاع الدنيا يذهب ينقب ينتهي عمره وهو لم ينتهى ، فالاشتغال بفضول الدنيا يقطع عن الله والدار الآخرة ، ويضيع العمر في تحصيل الثهوات في الترف . سادساً : يقود للتكاسل في العبادات : لأنه يربد التتعم بملذات الدنيا ، ما يجد فيد وقت لقراءة القرآن ولا للعبادة ولا لقيام الليل .

\section{عـلاج الترف : عـان}

( ـ عدم تعوبد النفس على الراحة والدعة والكسل . r. الزهد في الدنيا والتقليل منها وترك الانغماس فيها ـ r.أن ينظر الإنسان إلى من هو دونه في الدنيا ولا ينظر إلى من هو

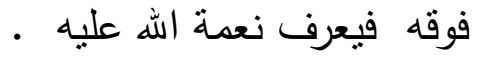


ع. تقصير الأمل : (( كن في الدنيا كأنك غريب أو عابر سبيل )) . ه. ترك بعض النعيم الذي يصبر عليه مع قدرته عليه ومن ترك اللباس تواضعاً لله كساه الله من حلل الإيمان يوم القيامة يلبس منها ما شاء . 7. مشاركة الإنسان الفقراء بما عندهم .

V. الدعاء بالاستعاذة من العجز والكسل وأن يجعل الله رزقه كفافاً وأن يكثر ذكر

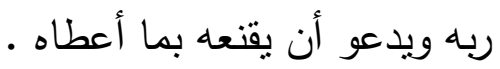
ومما ذكر ابن مفلح في كتابه الآداب الثرعية الجزء الثاني في هذا الثأن " قال المروذي عن أحمد :ما أعدلُ بالصبر على الفقر شيئًاً ، كم بين من يُعطي من الدنيا ليُفتنن إلى آخر تُرى عنه ـ قال : وذكرتُ لأبي عبداله عن بعض المفتين شيئا في

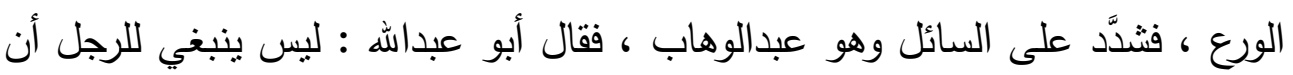

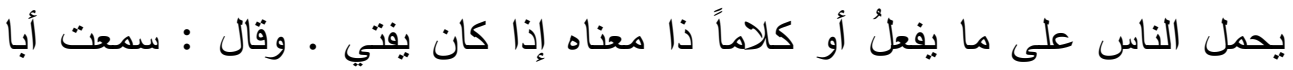

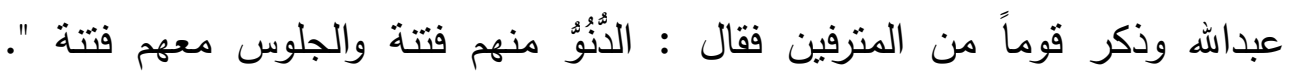
صqחז

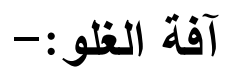

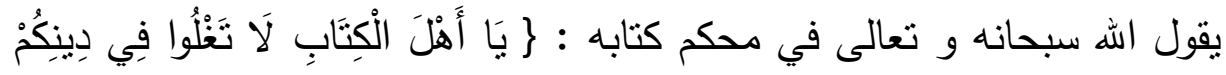

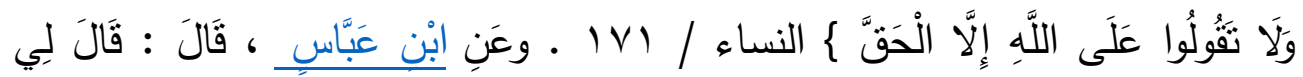

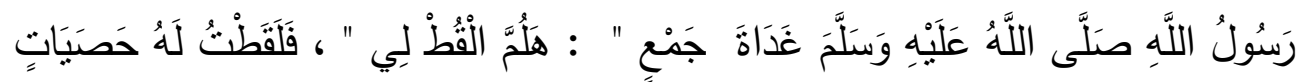

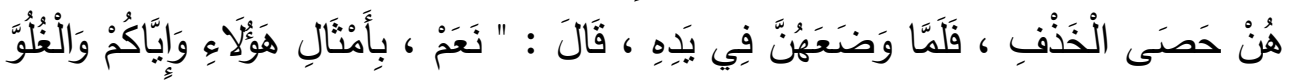

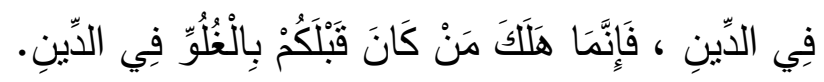

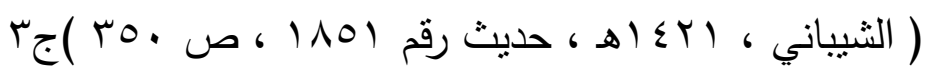
فالغلو في الدين آفة خطيرة كانت سببا لهلاك كثير من الأمم السابقة كما قال صلي الله علية وسلم :(فإنما هلك من كان قبلكم بالغلو في الدين ) .من أجل ذلك 
جاءت الآيات القرآنية ، والأحاديث النبوية محذرة من هذه الآفة .. ومبينة ما يترتب على الغلو من أضرار . . تعريف الغلو في اللغة :- تدور الأحرف الأصلية لهذه الكلمة ومشتقاتها على إنى

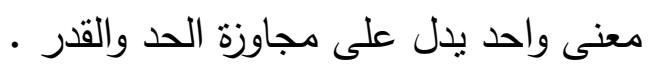

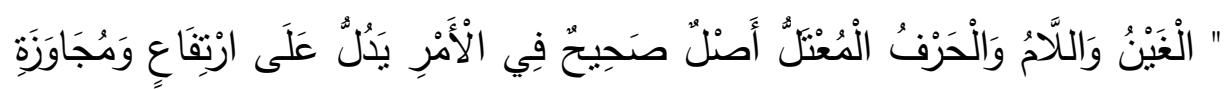

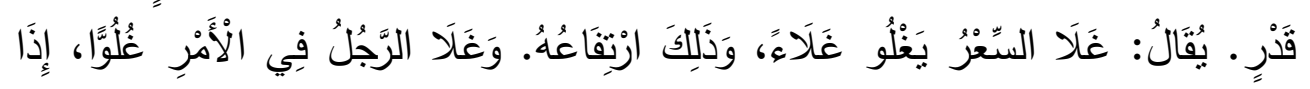

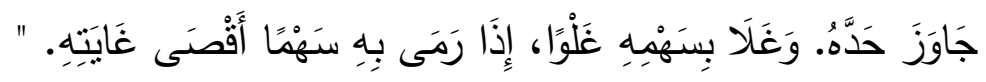

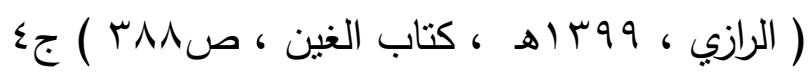
يقال غلا غلاءً فهو غال، وغلا في الأمر غلواً أي جاوز حده، وغلت القدر تغلي غلياناً، وغلوت بالسهم غلواً إذا رميت به أبعد مما تقدر عليه، فالغلو: هو مجاوزة الحد، يقال غلا في الدين غلواً تشدد، وتصلب؛ حتى جاوز الحد.

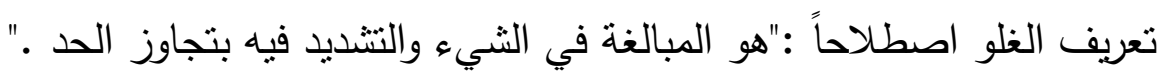
( العسقلاني ،

إذن الغلو هو: تجاوز الحد الثرعي بالزيادة ، " والحدود هي : النهايات لما

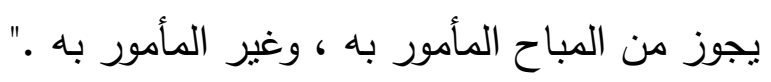

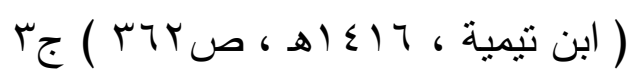

\section{مظاهر الغلو في زمانتا :-}

ا . التشدد في الدين على النفس والتعسير على الآخرين • r. الخروج عن منهج الاعتدال في الدين، الذي كان عليه النبي صلى اله عليه وسلم، وقد حذر النبي صلى الله عليه وسلم من ذلك في الحديث الثريف

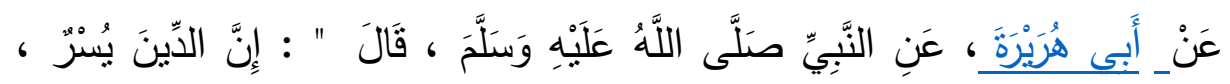

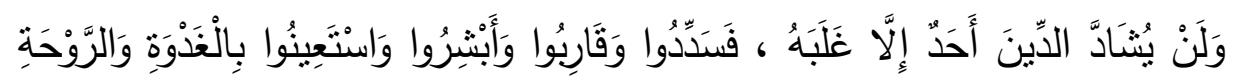

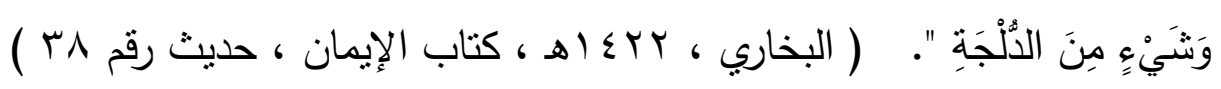


r. تكفير المجتمع على العموم ، حتى وصل الأمر ببعضهم أنهم كفروا من لا

$$
\text { بواققهم على آرائهم !!. }
$$

ـ. التعصب للرأي، وعدم الاعتراف برأي الآخرين • لإنم

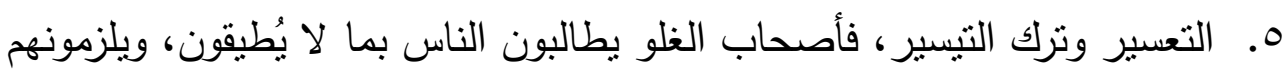
بما لا يلزمهح به الثرع السهل، ولا يراعون قدراتهم وتفاوتها ، وطاقاتهم واستطاعتهم وتباينها ، وأفهامه واختلافها ، فيخاطبونهم بما لا يفهمون ، وبطالبونهم بما لا يستطيعون 7. الدعوة الي العنف والخروج علي المسلمين بالسلاح ، وقتل الأبرياء وإثارة الفتن والقلاقل وعدم مراعاة حرمة دماء المسلمين . V. وهنالك من يتوقف في الناس فلا يحكم عليهم بشيء حتى يتحقق من صحة عقيدتهم مق

^. وهنالك من يحرم الصلاة في مساجد المسلمين ، وبعضهم يقول : لا نصلى إلا وراء من نعرف عقيدته !!. 9. يزعم بعضهم إن جماعتهم الوحيدة المسلمة في العالم !!.

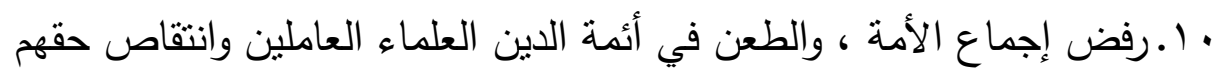
الـ التشدد في الفرعيات : وهذا يقع في كثير من الدعاة ـ وهو التزامهم التشدد في كل الأمور ، وكأن الأحكام الثرعية عند هؤلاء أصبحت حكمين ، الحرام والواجب ، مع إن الأحكام الثرعية تتقسم إلي خمسة أقسام معروفة ، والثريعة الغراء مبنية علي التيسير والتخفيف ورفع الحرج يقول الله سبحانه وتعالى :

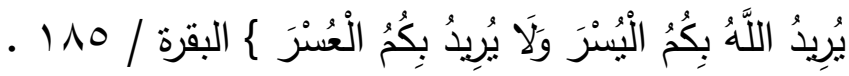

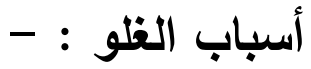

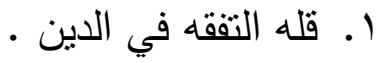
r. الاستعلاء غلى الغير بالعبادة . . أ. 
r. الجهل، فالجهل بتقهم حقيقة ما يرى وما يسمع وما يقرأ ومرمى ذلك . ع ـ تقريق لوحدة المسلمين ، وتمزيق صفوفهم • 0. إفساد القلوب وترويج الأكاذيب والإشاعات الباطلة . 7. فقدان الثقة في بعض العلماء .

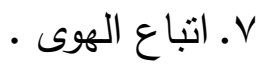

ومما ذكر ابن مفلح المقسي في كتابه الآداب الثرعية الجزء الأول في هذا

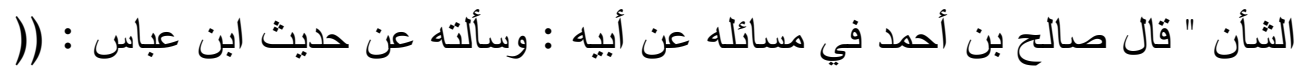
إياكم والغلو فإنما أهلك من كان قبلكم الغلو) قال أبي : لا تغلو في كل شيء حتى الحب والبغض ، قال أبو داود ( باب في الهوى ) حدثنا حيوة بن شربح ، حدثنا بقية ، عن ابن أبي مريم ، عن خالد بن محمد الثقي ، عن بلال بن أبي الدرداء ، عن أبي لني

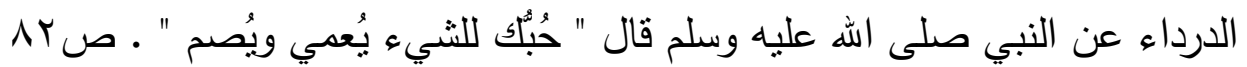
آفة الربا :

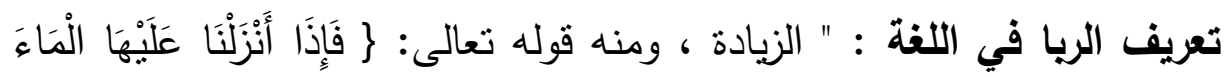

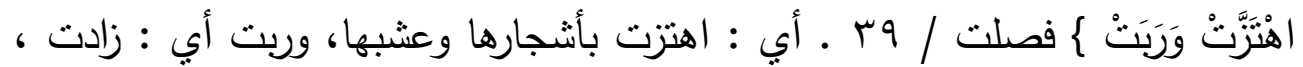
وليس المراد الأرض نفسها ، بل المراد ما ينبت فيها."

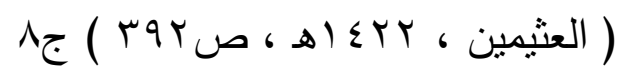

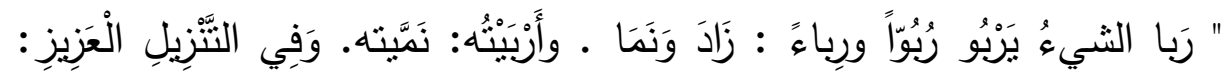

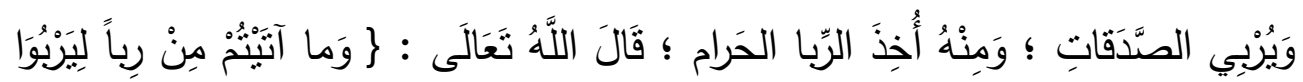

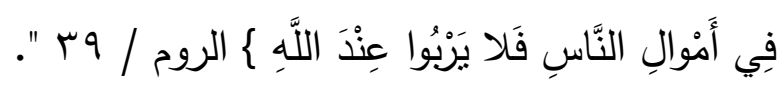

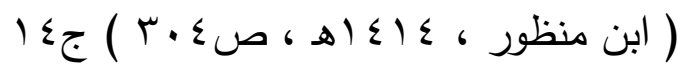

تعريف الربا شرعاً :- فهو زيادة في أشياء ونسأ في أثنياء ، ولو قيل : إن ربا الفضل هو التفاضل في بيع كل جنس بجنسه مما يجري فيه الربا ، وربا النسيئة

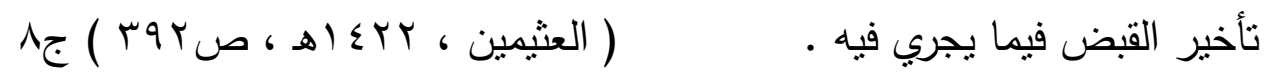


"وهو الزيادة في أثنياء مخصوصة والزيادة على الدَّين مقابل الأجل مطلقاً " .

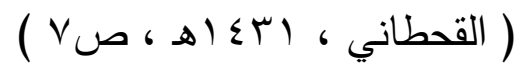

حكم الريا :- تدل الآيات والأحاديث على " تحريم الربا والتحذير منه ـ فالواجب على المسلمين جميعا تركه والحذر منه والتواصي بنركه. والواجب على ولاة الأمور من المسلمين منع القائمين على البنوك في بلادهم من ذلك ، وإلزامهم بحكم الثرع

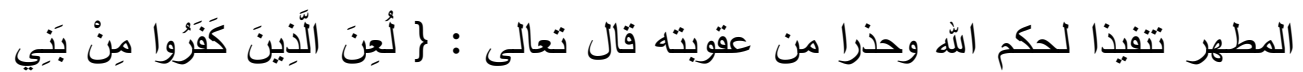

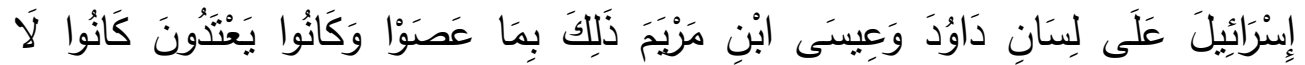

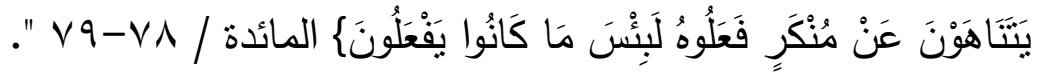

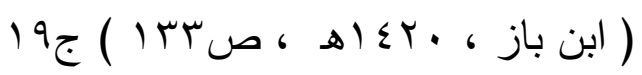

أنواع الريا :- الربا نوعان : ربا الديون ومعناه الزيادة في الدين مقابل الزيادة في الأجل ، وهذا الذي كان شائعا في الجاهلية ، وهو ما عليه العمل اليوم في البنوك الربوية فيما يسمى بالفائدة • وربا البيوع وهو بيع الأموال الربوية بعضها ببعض ـ وريا البيوع نوعان أيضا : البيان أ- ربا الفضل : ومثاله كمن باع عملة نقدية بنفس العملة بزيادة. ب- ربا النسيئة : ومثاله كمن باع عملة نقدية بنفس العملة بدون زيادة ؛ لكن تأخر القبض عن مجلس العقد . وهذا النوع من الربا جاءت السنة الصحيحة بتحريمه

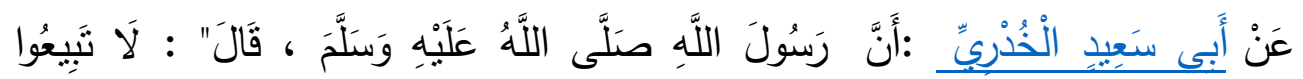

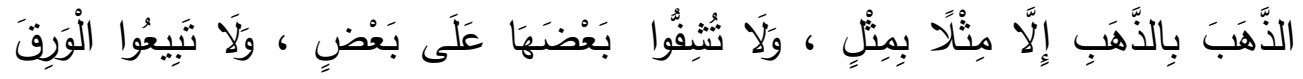

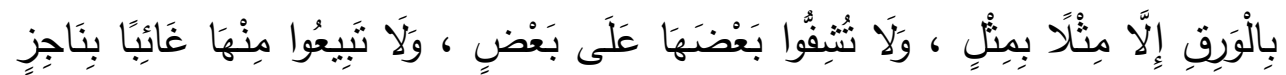

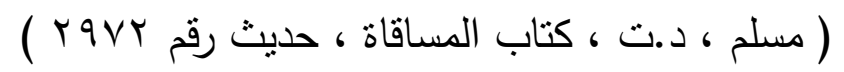

ومثل الذهب في الحكم الأوراق النقدية ، فعملة كل بلد تعتبر جنسا قائما بنفسه فلا تجوز المفاضلة بينها ، كما لا يجوز بيع نقود ورقية بنقود أخرى آجلة ولو اختلف الجنسان - اخلت 
مضار الربا :- أخطر شيء في الربا أنه يصرف الناس إلى استثمار أموالهم بطريقة الربا المريحة ، وبيعدهم عن اسنتمارها بالمشروعات الناجحة ، فالمجتمعات التي تستثر أموالها عن طريق المثاريع الصناعية والزراعية والخدمية مجتمعات متطورة ومجتمعات تتمو، والقاعدة كلما توافرت السلعة انخفض سعرها ، وإذا انخفض كائ سعرها كثر المنتفعون بها ، وإذا كثر المنتفعون بها عمّ الرخاء في المجتمع ، وفي القرآن الكريم آيات دقيقة قال تعالى :

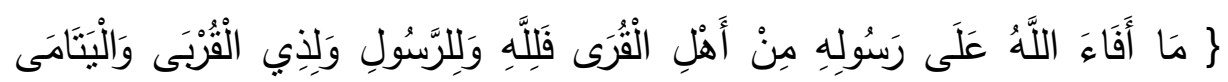

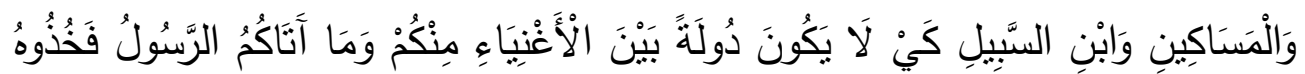

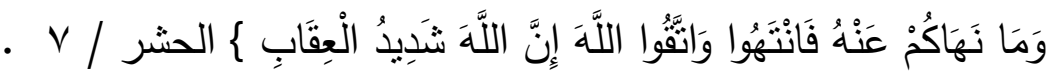
ومما ذكر ابن مفلح المقدي في كتابه الآداب الثرعية الجزء الأول في هذا الثأن " وقال المروذي : سألت أبا عبداله عن الذي يتعامل بالربا ، يؤكل عنده ؟ قال

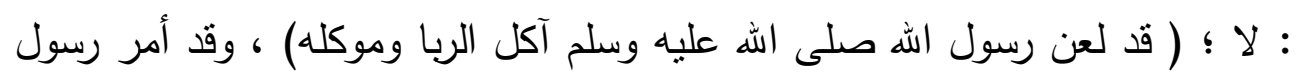
الله صلى الله عليه وسلم بالوقوف عند الثبهة " .ص979 79 وبتضح مما سبق ، مما أورده ابن مفلح من مضامين تربوية اجتماعية في كتابه الآداب الثرعية والمنح المرعية متعلقة بالآفات المهددة للمجتمع كالزنا والبخل والثح والترف والغلو وغيرها ، أن عواقبها وخيمة وأضرارها جسيمة على حياة الأمة ، سواء أكان ذلك على مستوى الأفراد أم المجتمعات ، هذه العواقب منها ما يكون في الدنيا ومنها ما يكون في الآخرة ، فلا بد من الوقوف على اسباب تفثيها وانتشارها ،

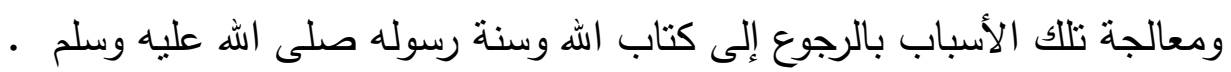


المطلب السادس :- ما المضامين التريوية الاجتماعية المتعلقة بعلاقة

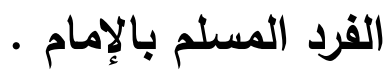

تتضمن علاقة الفرد المسلم بالإمام مجموعة من الواجبات والتي تتمثل في حقوق

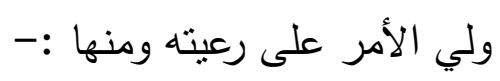

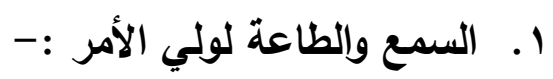

من أُصول العقيدة الصحيحة : السمع والطاعة لولاة أمر المسلمين في غير الطير

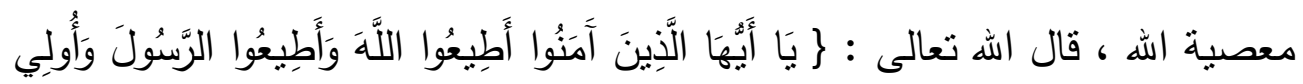

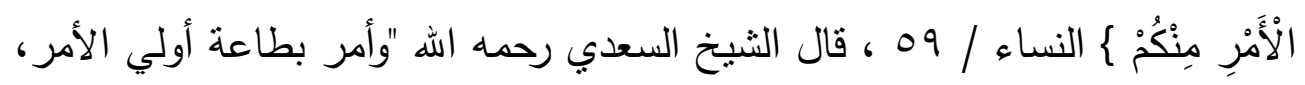

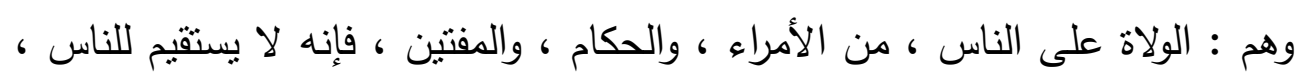

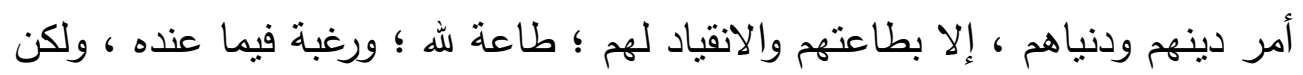

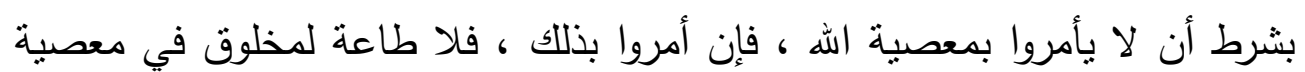

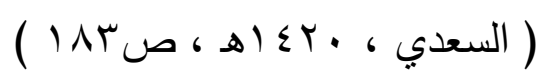

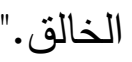

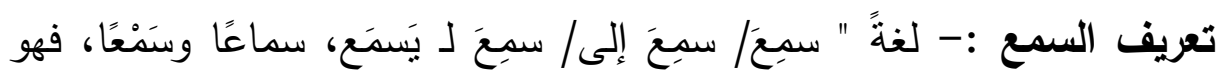

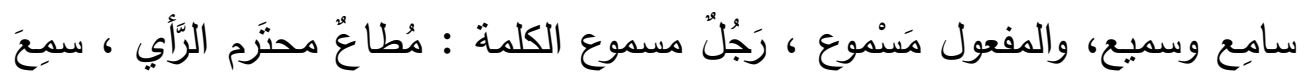

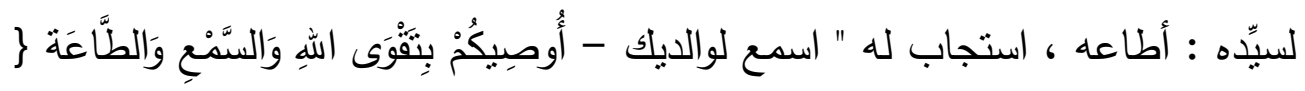

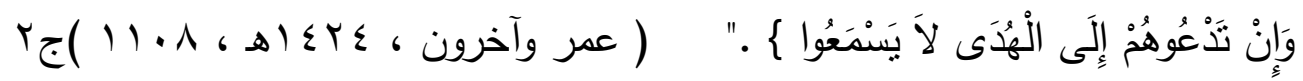

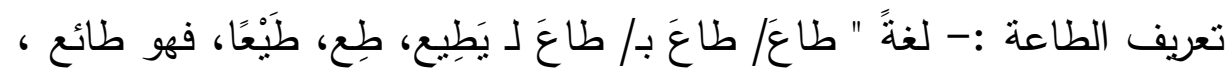

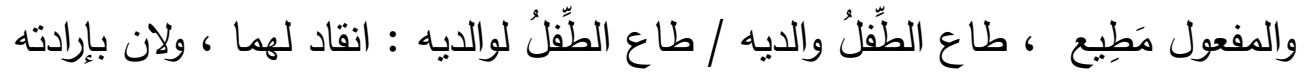

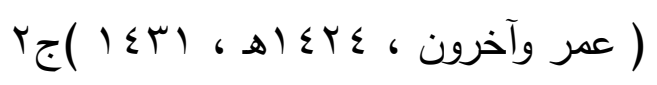

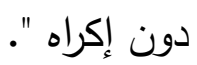

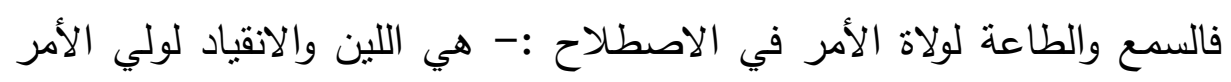

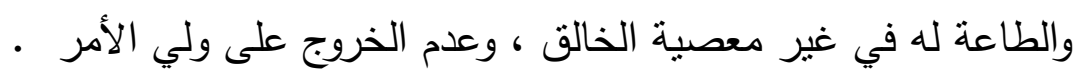


قال ابن تيمية رحمه الله : " إن الحاكم إذا ولاه ذو الشوكة لا يمكن عزله إلا بفتتة ومنى كان السعي في عزله مفسدة أعظم من مفسدة بقائه لم يجز الإتيان بأعظم الفسادين

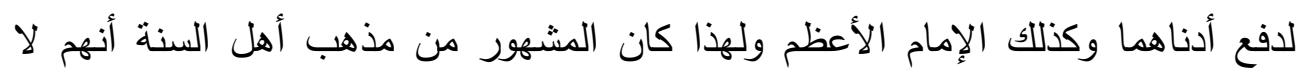
يرون الخروج على الأئمة وقتالهم بالسيف وإن كان فيهم ظلم كما دلت على ذللك الأحاديث الصحيحة المستفيضة عن النبي صلى اله عليه وسلم لأن الفساد في القتال والفتتة أعظم من الفساد الحاصل بظلمهم بدون قتال ولا فتتة فلا يدفع أعظم الفسادين بالتزام أدناهما ولعله لا يكاد يعرف طائفة خرجت على ذي سلطان إلا وكان في خروجها

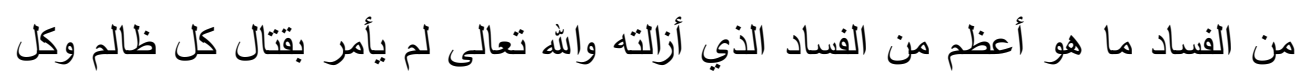

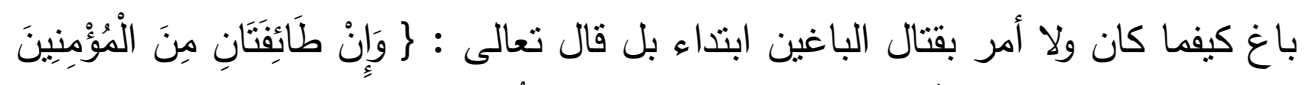

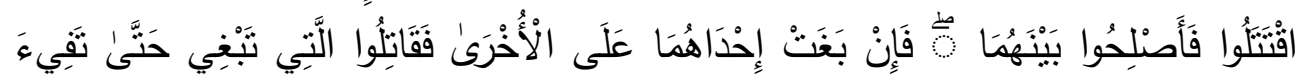

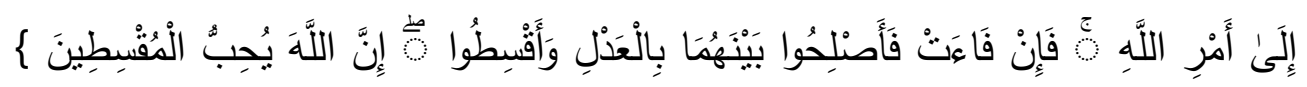
الحجرات/9 فلم يأمر بقتال الباغية ابتداء فكيف يأمر بقتال ولاة الأمر ابتداء ".

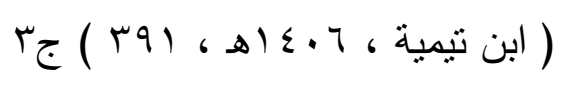

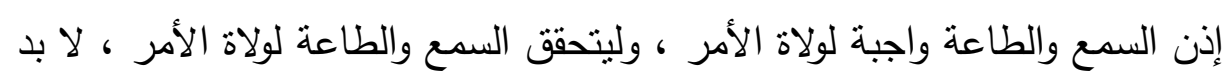

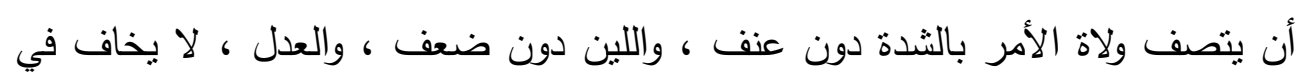

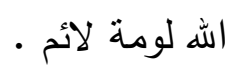
ومما ذكر ابن مفلح المقدسي في كتابه الآداب الشرعية الجزء الأول في هذا الشأن "

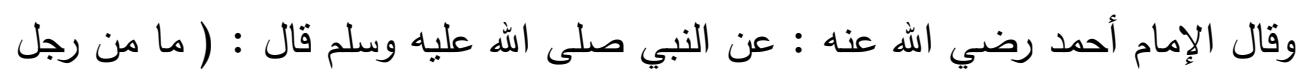

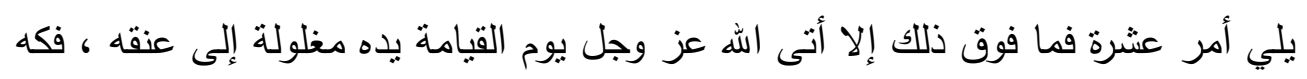

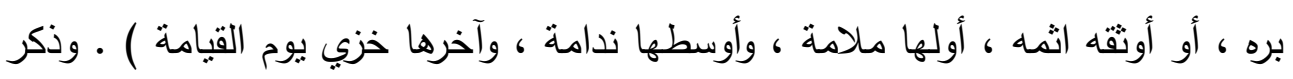

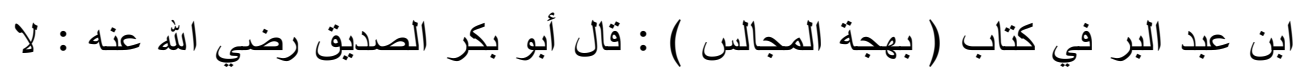
يصلح هذا الأمر إلا شدة في غير عنف ، ولين في غير ضعف ، وقال عمر بن

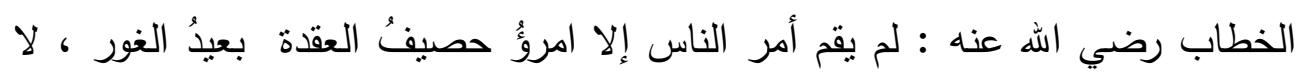

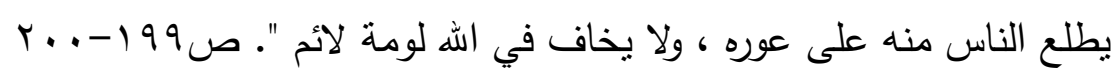


فالعلماءَ أجمعوا على وجوبٍ طاعةِ الحاكمٍ ، وأنّ طاعتَه خيرٌ من الخروبج عليه ، لما في ذلك من حقنِ الدّماءِ ، ولِمَا في الخروجِ عليه من شقِّ عصا المسلمين وإراقةٍِ

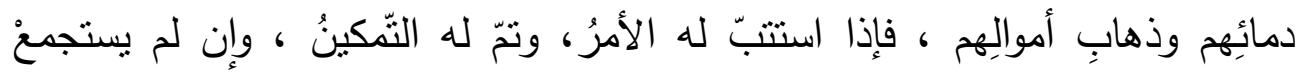

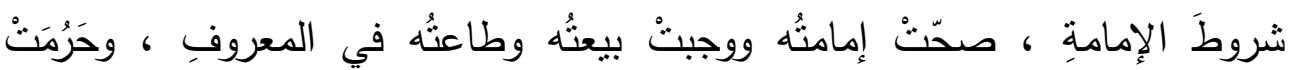

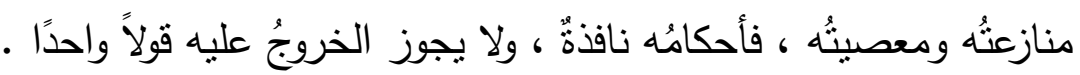

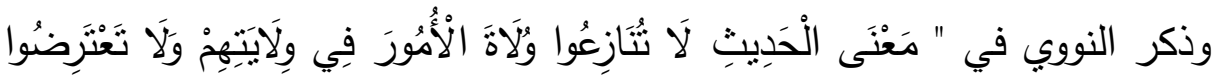

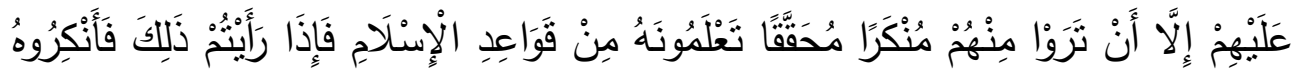

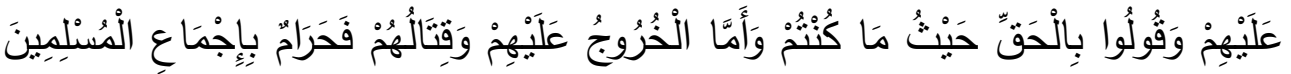

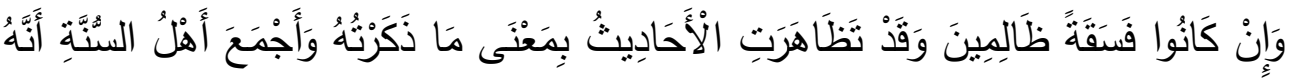

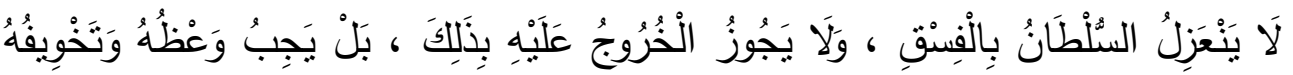

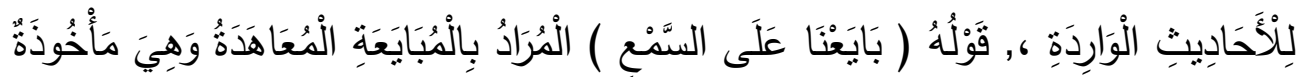

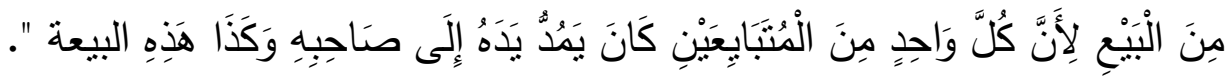

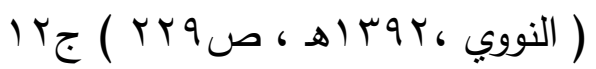

\section{r. النصيحة لولي الأمر ووعظه :-}

نصيحة ولي أمر المسلمين واجبة لقول الرسول صلى الله عليه وسلم : عَنْ تَمَيِعِ

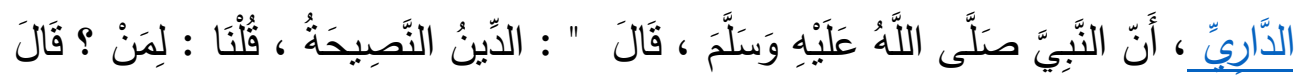

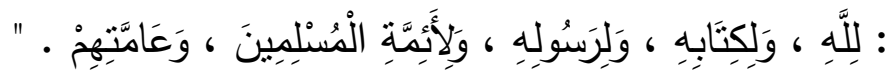

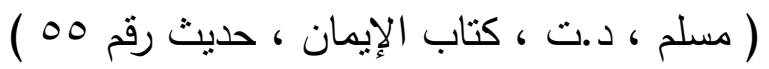

وهذا سؤال وجه لمعالي الثيخ صالح بن فوزان الفوزان وفقه الله حول الطريقة الشرعية في مناصحة ولي الأمر وخاصة في هذا الزمن الذي كثرت فيه الفتن مع بيان المنهج الثرعي في كيفية المناصحة وبيان ذلك بالأدلة الثرعية من الكتاب والسنة وفهم السلف الصالح ، وهل هناك مفاسد مترتبة في المناصحة العلنية لولي الأمر. وكانت اجابته على النحو الآتي :- نصيحة ولي أمر المسلمين واجبة لقوله صلى لله 
عليه وسلم: "الدين النصيحة"، قلنا لمن يا رسول الله قال: "له ولكتابه ولرسوله ولأئمة المسلمين وعامتهم"، ولكنها تكون سرًا بين الناصح وولي الأمر، بدليل حديث: "من لئ

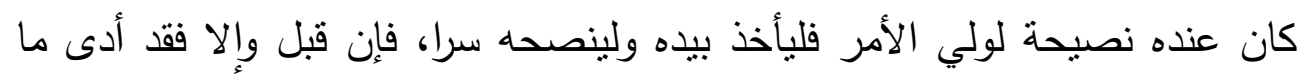

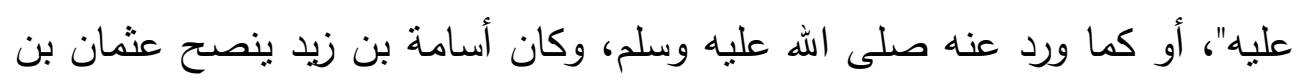
عفان أمير المؤمنين رضي الله عنه سرًا ولا يظهر ذلك للناس هذا هو السنة في

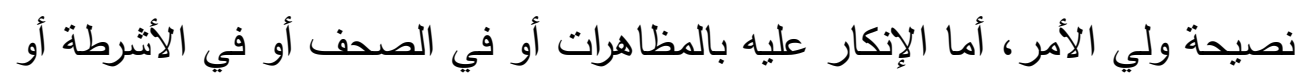
في وسائل الإعلام أو في الكتب والمنشورات فكل ذلك خلاف السنة وهو يفضي إلى بلى مفاسد وفنن وشرور وتحريض على الخروج على ولي الأمر ويفرق بين الراعي والرعية ويحدث البغضاء بين ولي الأمر والرعية وليس ذلك من هدي الإسلام الذي يحث على ولى ولى ولى جمع الكلمة وطاعة ولي الأمر فهو أمر منكر وليس من النصيحة في شيء وإنما هو من الفضيحة حتى في حق أفراد الناس فكيف بولي الأمر. ومما ذكره ابن مفلح المقدي رحمه الله في كتابه الآداب الشرعية الجزء الأول في هذا الثأن " قال ابن الجوزي رحمه الله : الجائز من الأمر بالمعروف والنهي عن الن النه المنكر مع السلاطين التعريف والوعظ فأما تخشين القول نحو يا ظالم يا من لا يخاف

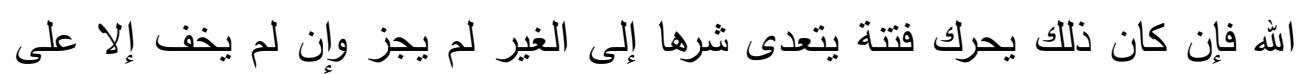
نفسه فهو جائز عند جمهور العلماء قال والذي أراه المنع من ذلك لأن المقصود إزالة المنكر وحمل السلطان بالانبساط عليه على فعل المنكر أكثر من فعل المنكر الذي قصد إزالته قال الإمام أحمد رحمه الله لا يتعرض للسلطان فإن سيفه مسلول وعصاه فأما ما جرى للسلف من التعرض لأمرائهم فإنهم كانوا بهابون العلماء فإذا انبسطوا

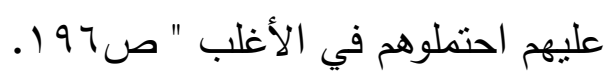
قال الثيخ ابن باز رحمه الله : " ليس من منهج السلف النتهير بعيوب الولاة

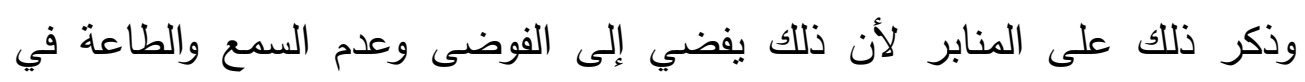
المعروف ، ويفضي إلى الخوض الذي يضر ولا ينفع ، ولكن الطريقة المتبعة عند 
السلف النصيحة فيما بينهم وبين السلطان ، والكتابة إليه ، أو الاتصال بالعلماء الذين

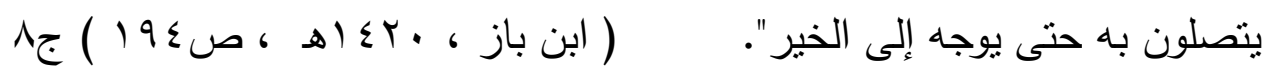

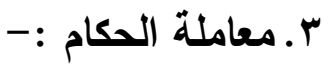

منهج أهل السنة والجماعة في معاملة الحكام :- إن لأهل السنة معرفة بحقوق

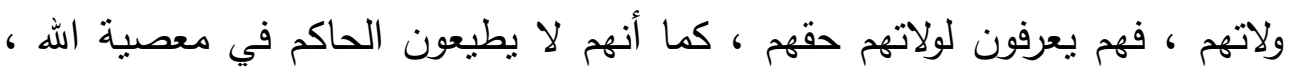

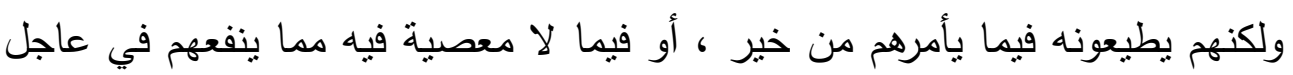

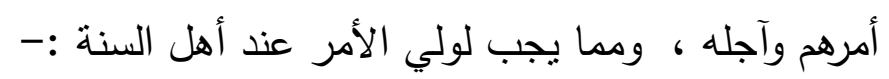

أولا: البيعة لهم : - فالبيعة لولي الأمر من حكمة الله البالغة ، أن شرع لهذه الهم الأمة الراثدة من بسوسهم لتتنظم أمورهم ، وتصلح شؤونهم ، لأنه لو لم بكن حاكم

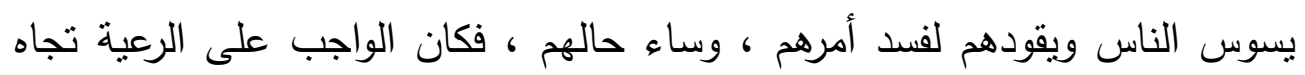
إمامهم البيعة له .

ثانيا: السمع والطاعة في المعروف: - إن مما يجب للحاكم على رعيته :من واجب الرعية للحاكم السمع والطاعة في غير معصية الله عز وجل فقد أجمع أهل السنة والجماعة على وجوب السمع والطاعة لولي الأمر في غير معصية الله . ثالثا: الصبر على جور ولاة الأمور: إن مما يجب لولي الأمر على المسلم : الصبر على جوره ، لأن الحاكم قد يظلم ، ومنهج أهل السنة فى معاملة ظلم الحكام أنهم يصبرون ، وهذا ما كان عليه السلف الصالح رحمهم الله كالإمام أحمد بن حنبل ، والإمام الأوزاعي ، والإمام مالك رحمه الله جميعا ، صبروا وصابروا، كل ذلك ليس

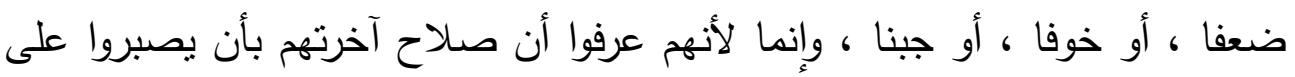

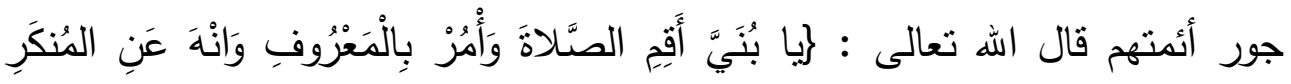

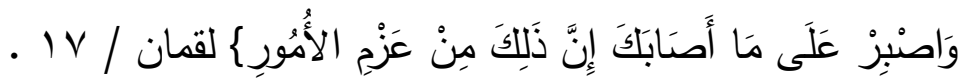
لابعا: النصح لولاة الأمور: - مما يجب على المسلم تجاه الولاة النصح لهم ، وهذا الأمر يغفل عنه كثثر من المسلمين اليوم ، فلا ينصح لإمامه ، ودائرة النصح 
واسعة ، فالمراد بالنصح أن تتصح في مكانك ، أو في موقعك الذي أنت فيه ، فإن

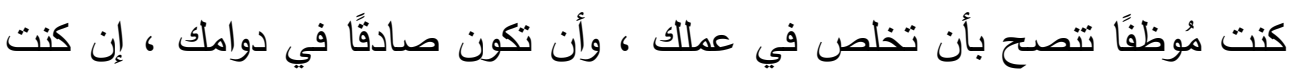

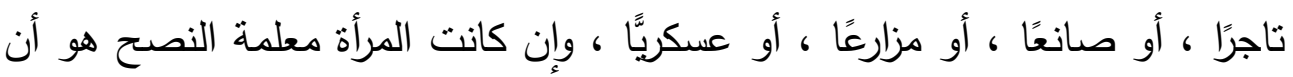

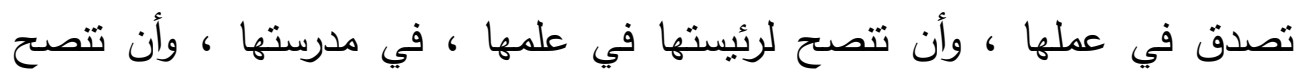

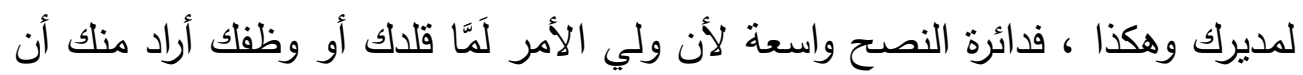
تكون صنَادقًا في عملك ، صادقا في دوامك ، صادقا في أخذلك وإعطاءك. خامسا: توقير ولي الأمر واحترامه: - ومما يجب على المسلم تجاه ولي أمره :

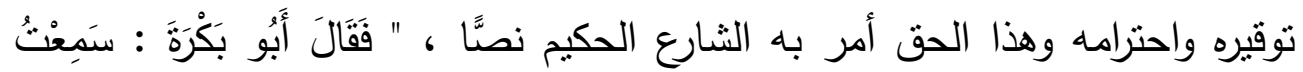

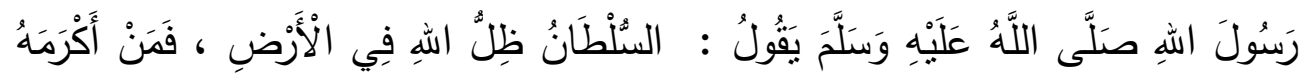

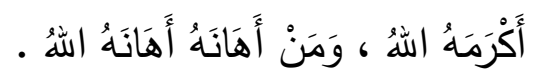

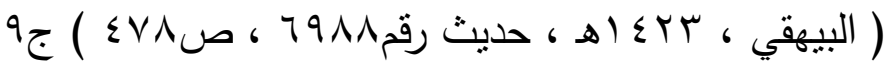

ومن احترام الإمام ، احترام المسئولين في الدولة كالوزراء ، وإن كنت أكثر منهم علما أو عبادة . ومما ذكره ابن مفلح المقدسي رحمه الله في كتابه لآداب الثرعية الجزء الثالث في هذا الثأن من معاملة الحكام " وتباعد كعب الأحبار يوماً في مجلس عمر بن الخطاب رضي الله عنه ، فأنكر ذلك عليه ، فقال : با أمير المؤمنين ، إن في حكمة لقمان ووصيته لابنه : أذا جلست إلى ذي سلطان فليكن بينك وبينه مقعد رجل فلعله

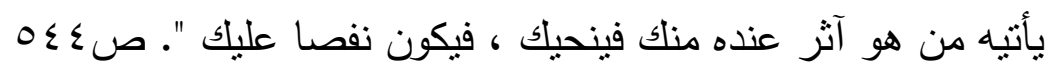
ويتضح مما سبق ، مما أورده ابن مفلح من مضامين نربوية اجتماعية في كتابه الآداب الثرعية والمنح المرعية في علاقة الفرد المسلم بالإمام ، أن تأسيس العلاقة بين الحاكم والمحكوم في الفكر الإسلامي لم تكن ناشئة من فراغ أو صادرا من بنيات

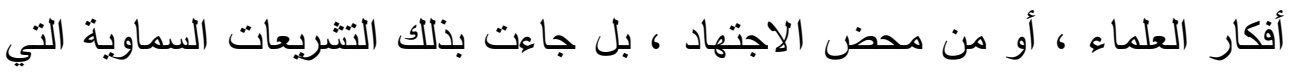
نزلت على محمد صلى الله عليه وسلم من خلال القرآن الكربم ، والسنة النبوية الثريفة 
بل إن النصوص المتعلقة بالموضوع كثيرة جدا يصعب على المتتبع حصرها يقول

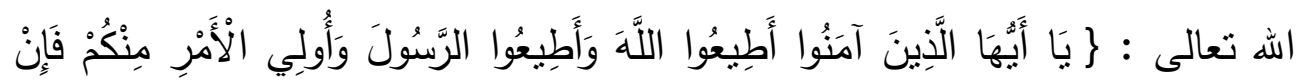

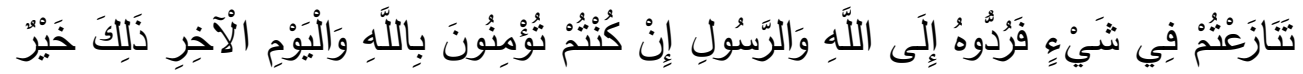

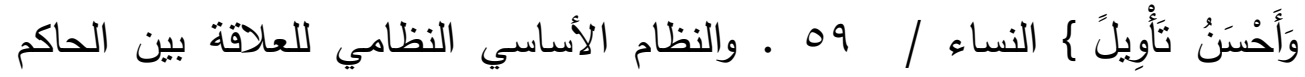
والمحكوم في الاسلام يقوم على : المبايعة على السمع والطاعة في العسر واليسر، والمنشط والمكره ، و الدفاع عن العقيدة الإسلامية والمجتمع والوطن ، و حق التقاضي مكفول بالتساوي للجميع ، مع التزام العدل ، والنصيحة لولي الأمر ، والجهاد

\section{المبحث الثالث :- بيان التطبيقات التريوية للمضامين التربوية}

\section{الاجتماعية المستنبطة من كتاب الآداب الشرعي في الحيا اليومية ؟} ذكر ابن مفلح في كتابه الآداب الثرعية والمنح المرعية العديد من المضامين التربوية الاجتماعية التي تمثل لنا وصايا بليخة وآداب نفيسة : مشتقة من الكتاب والسنة ، تصلح الأمة ، وتصون الإنسان من الوقوع في الذلل والخطأ ، وتحمي الأسر والمجتمعات من الاخطار والثرور ، هذه المضامين التربوية الاجتماعية اذا توفرت في المجتمع والتزم بها فإنه تعم الفضيلة وتتنشر في المجتمعات ، ولتعميم هذه المضامين وغرسها وتعزيزها في نفوس الناشئة ، فلا بد أن تقوم مؤسسات التربية في المجتمع بدورها الفعّال ، كلٍ فيما يخصه ومن أهم التطبيقات التربوية للمضامين التربوية الاجتماعية المستتبطة من كتاب حرص الأسرة

ا. حرص الوالدين على إبعاد المنكرات وأجهزة الفساد عن الأبناء وتجنيبهر الزينة الفارهة والميوعة القاتلة . r. حرص الوالدين على تعوبد الأبناء على فعل الخيرات وإلزامهم بالأعمال الصالحة التي تتطلب مشقة ومجاهدة للنفس • 
r. حرص الوالدين والمعلمين على اقتناص الفرص المناسبة لتعريف الناشئية بآداب اكرام

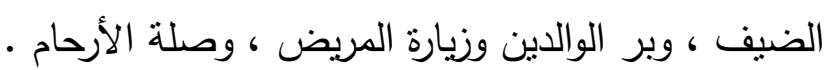

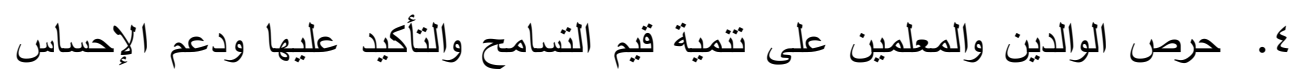

$$
\text { بنبذ الإرهاب ورفضه بجميع أثكاله . }
$$

ه. حرص الوالدين على تحقيق الاستقرار الأسري لان هناك ارتباط واضح بين فقدان

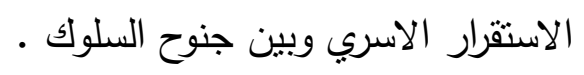

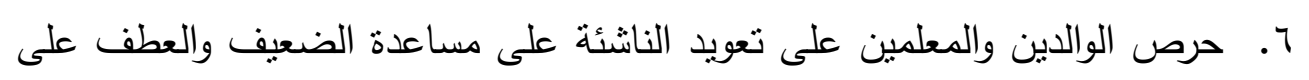

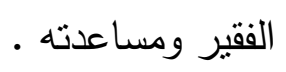

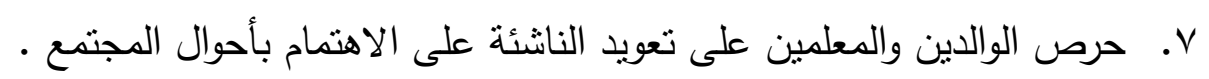

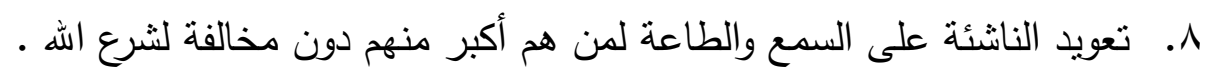
9 . . تدريب النانئة على البَّر والإحسان للوالدين والتحلي بالرحمة والأدب مع جميع أفراد

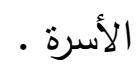

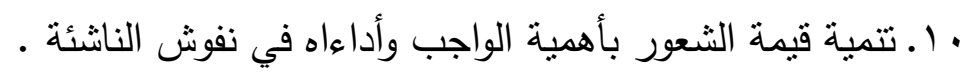

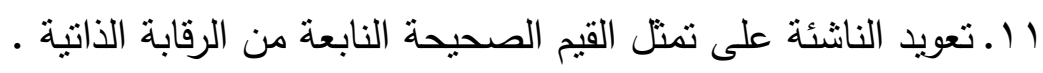
r ا. تنمية الثعور بالمسؤولية الاجتماعية لدى الناشئة وخلق الدوافع الإيجابية عندهم

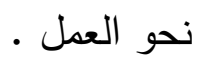

با ا. حرص الأسرة والمدرسة ووسائل الإعلام على إحياء مفهوم الاستشارة والاستتارة

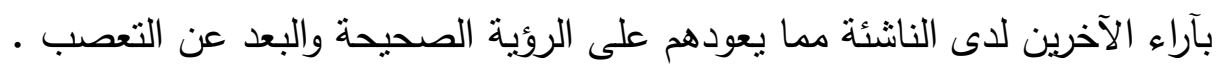

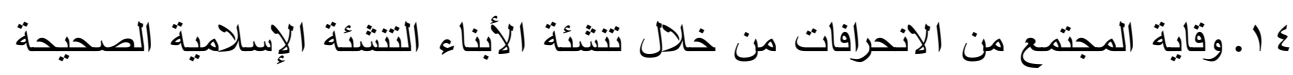

0 ا ـ تعربف الناشئة بأن قضاء حوائج المسلمين وتيسير أمورهم من الأسباب الجالبة لكل

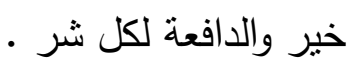


7 ا.تطبيق مفهوم حب الخير والسعي في قضاء حوائج الآخرين من خلال انشطة المدرسة كجمعية الإسعافات الأولية ، وجمعية النظافة ، وجمعية الخدمة الاجتماعية ، وجمعية حفظ النظام ... وغيرها .

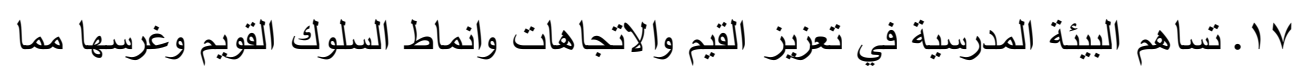

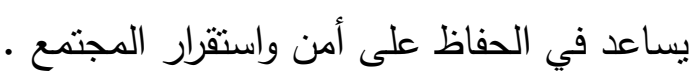
1 ا.تكافل المجتمع ووقوفه صفاً واحداً أمام كل المتغيرات التي تقسد عليه ليه معتقداته وقيمه واخلاقه هو حماية له وحفاظ على سلامته وتأكيد على تماسكه وقوته .

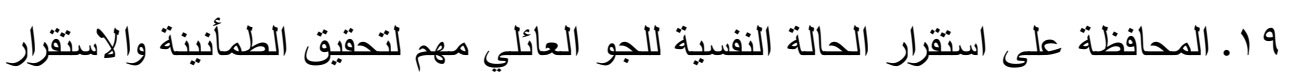

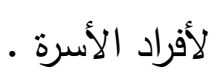

• r. تحقيق الوعي الأمني لدى أفراد المجتمع مهم جداً لحماية المجتمع من أخطار كثيرة

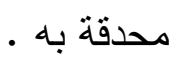

اب. تربية الناشئة على قبول الحق وعدم الاستبداد بالرأي والبعد عن التكبر الذي هو صفة ابليس وكان سبياً لطرده من رحمة الله ، وبيان سلبيات الكبر للناشئة بطرق

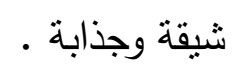

r r.بُعد المربين عن الألفاظ التي تدعم العصبية القبلية والتحيز لجنس دون أخر ،

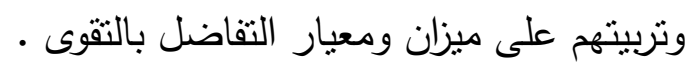

بr. البعد عن الإسراف والترف ، فمحبة الأبناء لا تعني الإسراف والتبذير المبالغ فيه ، واستحباب التوسط .

گ گ. تربية الناشئة على شيء من الحرمان من الكماليات حتى لا تطغى اللذة المادية ،

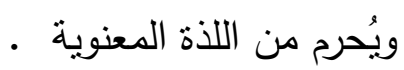

هr. على المربين بيان الحقوق والواجبات للناشئة سواء كانت تجاه الأب أو الأم أو الأخوة أو ولي الأمر أو المسلمين عامة . لان דr. على المربين بيان فضل الكرم للنانشئة وأنه من أحسن الثمائل الاجتماعية في الإسلام.

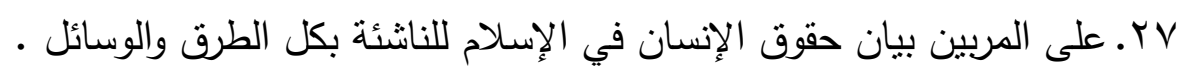




\section{المبحث الرابع :- التوصيات :-

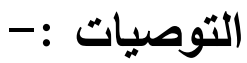

ا ـ على المؤسسات التربوية إبراز دور العلماء في حياة الأمم من خلال تتشئة الأبناء على احترامهم وتوقيرهم وتتبع آنارهم والاقتداء بهم .

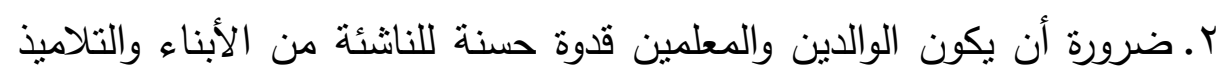
في أقوالهم وأفعالهم . r. على مؤسسات التربية دعم العلاقات الاجتماعية بين الآباء والأبناء لدى الناشئة من خلال حثهم على ( البر بالوالدين ، واحترامهم ، والاستغفار لهم ، وطاعتهم في غير معصية للخالق ، وصلة رحمه ) . ع. على مؤسسات التربية مهمة دعم العلاقات الاجتماعية بين الأفراد وولاة الأمر لاى الناشئة من خلال تعريفهم بوجوب السمع والطاعة لولاة الأمر دون معصية الخالق والنصيحة لهم والجهاد معهر • 0. على مؤسسات التربية مهمة دعم العلاقات الاجتماعية بين المسلم والمسلم لاى الناشئة من خلال حثهم على موالاة المسلم والنصح له وتقديم الخير ، وحسن الجوار ، وزيارة المريض ، والمحافظة على آداب الصحبة ، والتكافل الاجتماعي بين - المسلمين 7. توجيه دعوة لجميع المنظمات الدولية المعنية بحقوق الإنسان لقراءة جديدة

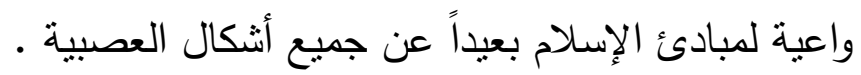




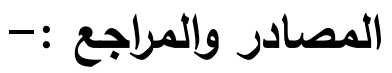

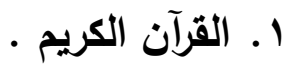

r. ابن الأثير ، مجد الدين أبو السعادات المبارك بن محمد بن محمد بن محمد ابن

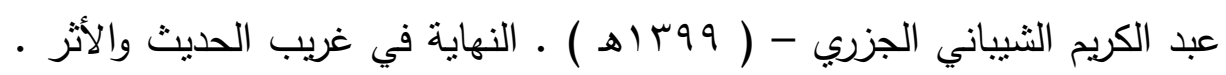
تحقيق : طاهر أحمد الزاوي - محمود محمد الطناحي ، بيروت : المكتبة العلمية .

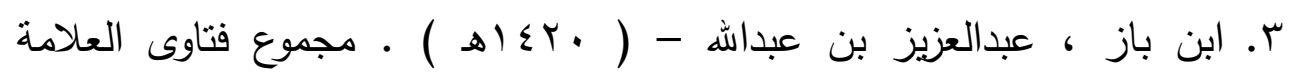

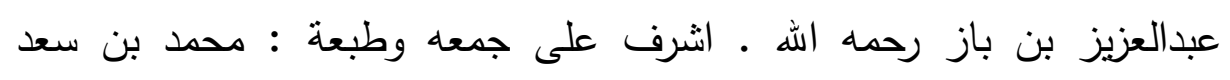
الثويعر ، الرياض : دار القاسم للنشر.

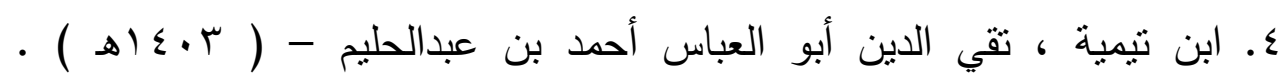
الاستقامة ـ تحقيق : محمد رشاد سالم ، المدينة المنورة : جامعة الإمام محمد بن بن بن

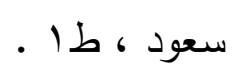
ه. ابن تيمية ، تقي الدين أبو العباس أحمد بن عبدالحليم - ( 1 إع الهـ ) ـ مجموع الفتاوى • تحقيق : عبدالرحمن بن محمد قاسم ، المدينة المنورة : مجمع الملك فهز لطباعة المصحف الثربف . 7. ابن تيمية ، تقي الدين أبو العباس احمد بن عبدالحليم بن عبدالسلام -

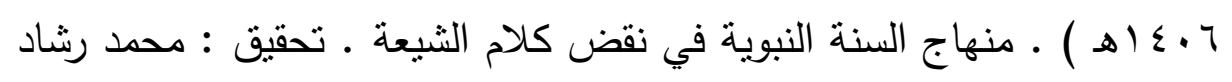

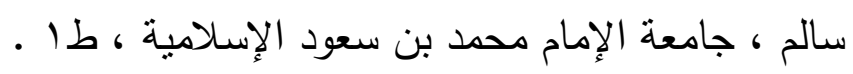

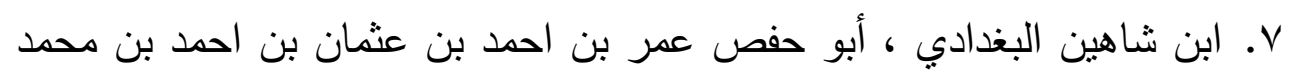

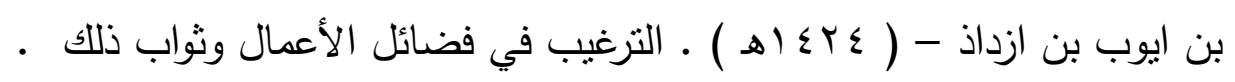

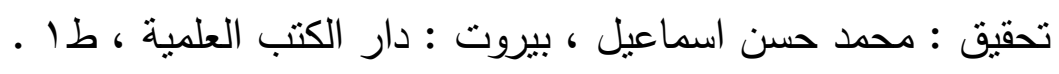

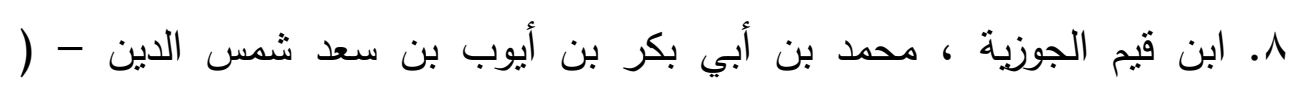

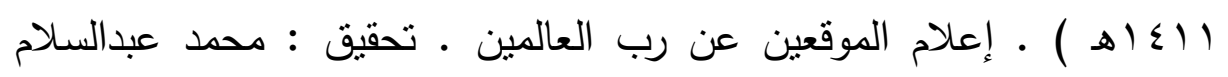

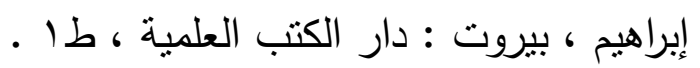


9. ابن قيم الجوزية ، أبو عبداله محمد بن أبي بكر بن أيوب - ( 9 ( أه ) ) . الداء والدواء • تحقيق : محمد أجمل الإصلاحي ، مكة المكرمة : دار عالم الفوائد ، طا ل

• . . ابن كثير ، اسماعيل بن عمر - ( ع أهـ ) . تقسير القرآن العظيم . تحقيق : محمد حسين شمس الدين ، بيروت : دار الكتب العلمية ، طا ـ 1ا. ابن ماجة ، أبو عبداله محمد بن يزيد القزويني - ( د . ت ) . سنن ابن ماجة . تحقيق : محمد فؤاد عبدالباقي ، فيصل عيسى البابي الحلبي : دار احياء الكتب العربية. T ا. . ابن مفلح ، أبي عبداله محمد بن مفلح المقدي - ( 7 اءـ اهـ ) . الآداب الثرعية والمنح المرعية . تحقيق : شعيب الأرناؤوط وعمر القيام ، سوريا :

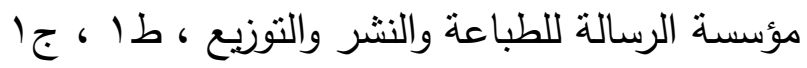

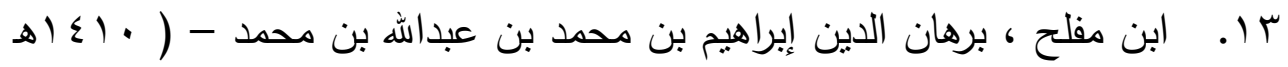
) · المقصد الأرشد في ذكر أصحاب الإمام أحمد. تحقيق :عبدالرحمن بن

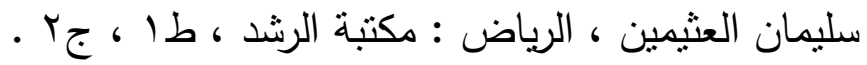

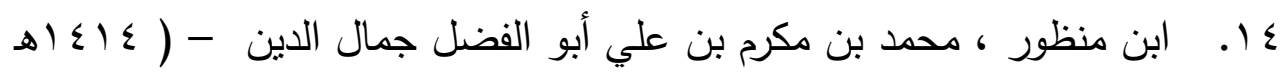
) • لسان العرب • بيروت : دار صادر ، طب .

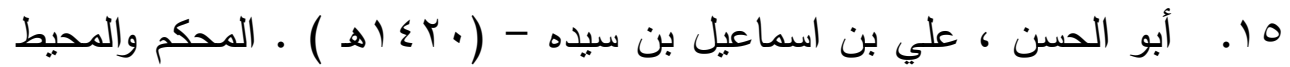

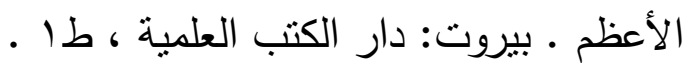
7 1. أبو شوشة ، محمد ناجح - (

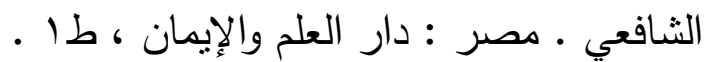

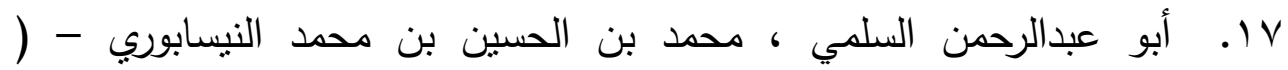
ץاء (هـ ) . آداب الصحبة . تحقيق : مجدي فتحي السيد ، طنطا : دار

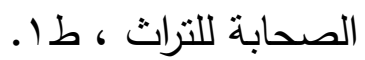


11. أبو هواش ، محمد أحمد بحيري _ ( باء اهـ ) . المنهج الأخلاقي عند ابن مفلح · رسالة ماجستير غير منشورة ، كلية دار العلوم قسم الفلسفة الإسلامية ، جامعة القاهرة .

9 1. أبي داود ، سليمان بن الأشعث بن اسحاق بن بشير بن شداد بن عمرو

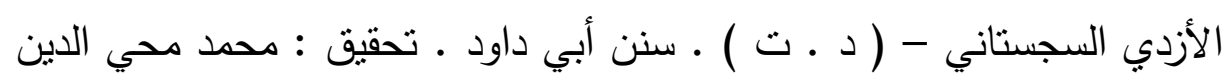
عبدالحميد ، بيروت : المكتبة العصرية .

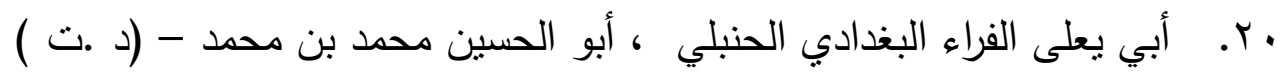
• طبقات الحنابلة ـ تحقيق : محمد حامد الفقي ، بيروت : دار المعرفة . ا T. الأصبهاني ، أبو محمد عبداله بن محمد بن جعفر بن حيان الأنصاري المعروف بأبي الثيخ - ( r إ اهـ ) ـ طبقات المحدثين بأصبهان والواردين عليها ـ تحقيق : عبدالغفور عبدالحق البلوشي ، بيروت : مؤسسة الرسالة ، طب

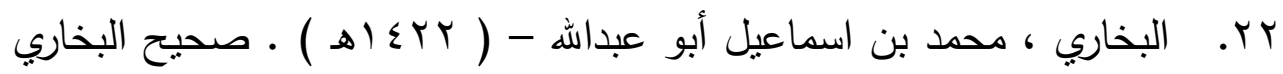
ـ تحقيق : محمد زهير ناصر الناصر ، دار طوق النجاة ، طا . rr. البركتي ، المفتي السيد محمد عميم الإحسان المجدي - ( ع ع اهـ ) . التعريفات الفقهية ـ بيروت : دار الكتب العلمية ، طا ـ العية

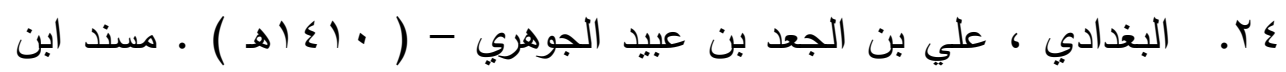

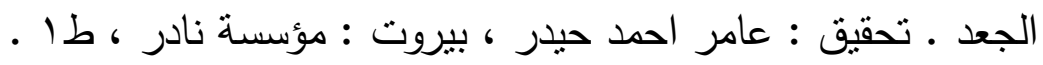

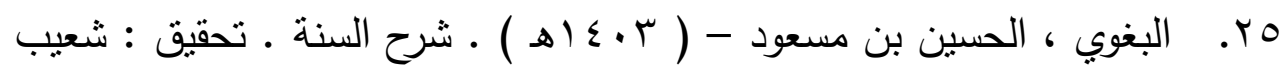

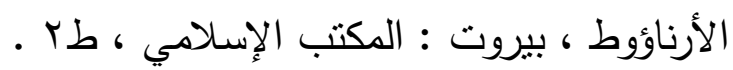

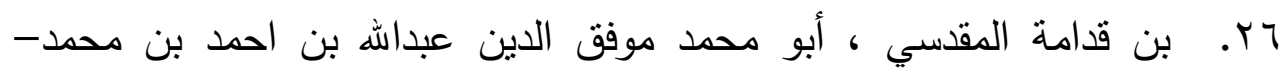

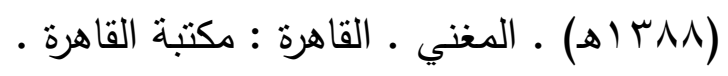

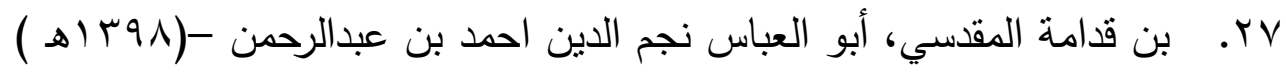
مختصر منهاج القاصدين ـ تقديم : احمد محمد دهمان ، دمشق : دار البيان 


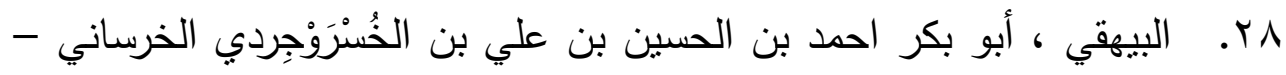

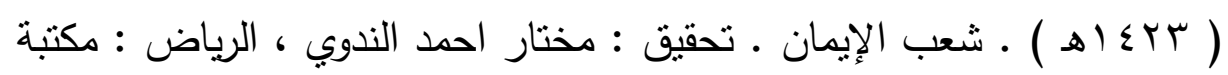

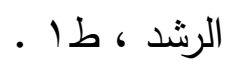

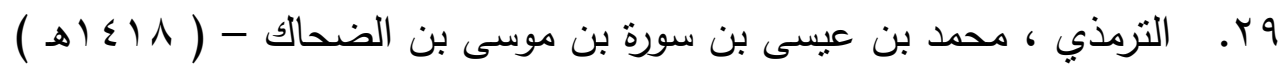
• الجامع الكبير سنن الترمذي • تحقيق بشار عواد ، بيروت : دار الغرب

$$
\text { الإسلامي . (الإنع }
$$

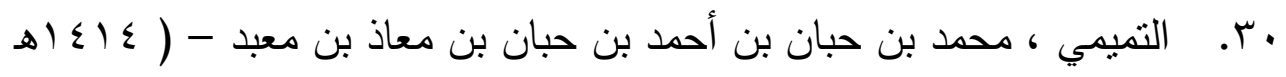
) · صحيح ابن حبان بترتيب ابن بلبان • تحقيق : شعيب الأرناؤوط ، بيروت :

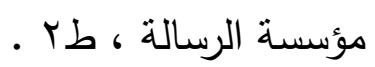

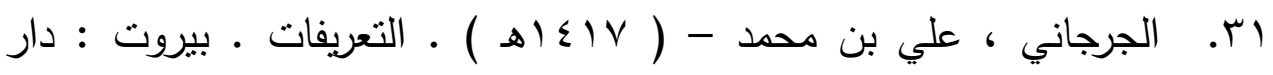

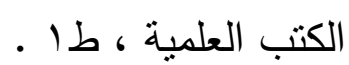

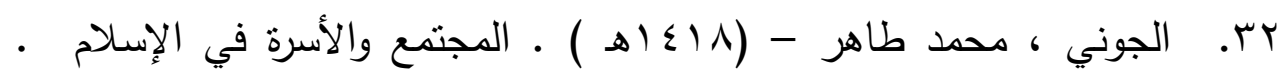

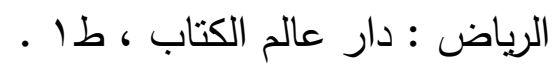

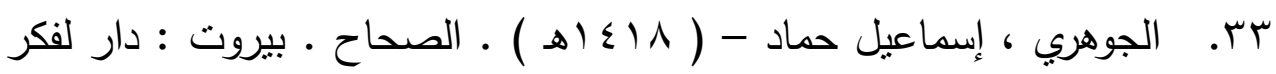

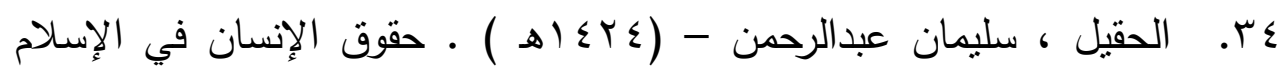
والرد على الثبهات المثارة حولها ـ الرياض : المؤلف ، طء .

هب. الخطابي ، حمد محمد - ( 0. ـ اهـ ) . غريب الحديث . مكة المكرمة : جامعة أم القرى •

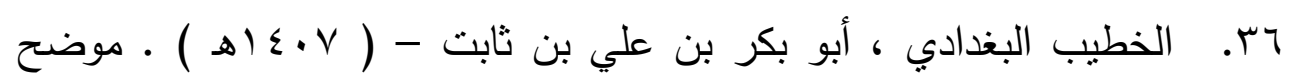

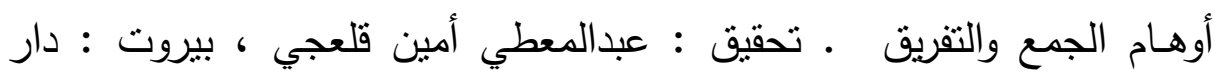

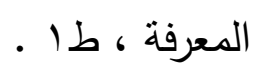


rV عبداله محمد بن مفلح المتوفي ( سجVهـ ) رحمه الله من باب صوم التطوع الى نهاية كتاب المناسك " دراسة وتحقيق " • رسالة دكتوراه غير منشورة ، كلية

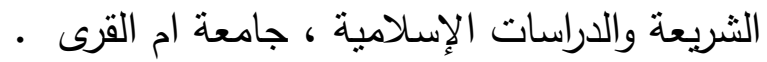

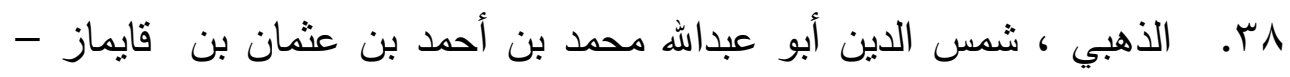

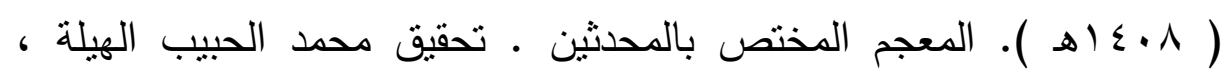
الطائف : مكتبة الصديق ، طا له ، جالـ

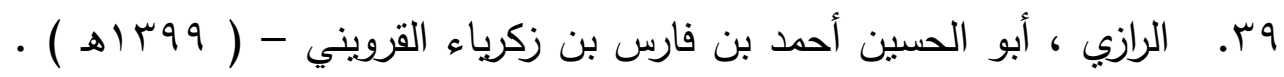
مجمع مقاييس اللغة ـ تحقيق : عبدالسلام محمد هارون ، بيروت : دار الفكر .

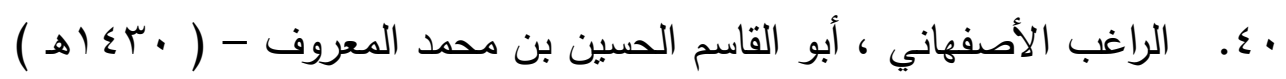
المفردات في غريب القرآن • تحقيق : صفوان عدنان داوودي ، دمشق : دار القلم ( الدار الثامية ) ، طع .

اء. الزبيدي ، محمد بن محمد بن عبدالرزاق الحسيني ، أبو الفيض ،الملقب بمرتضى - ( 79 آهـ ) . تاج العروس من جواهر القاموس ، تحقيق : مجموعة من المحققين ، الكوبت : مطبعة الكويت الحكومية ، طب .

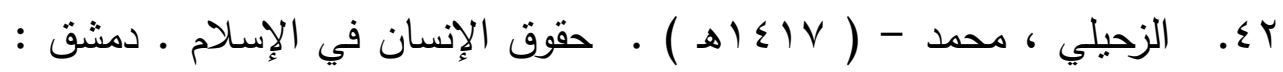

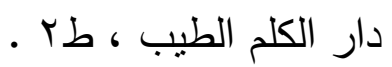

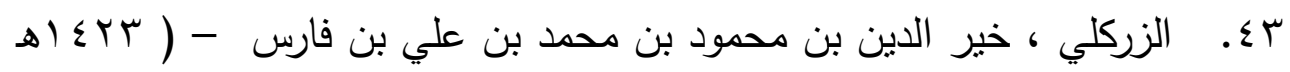

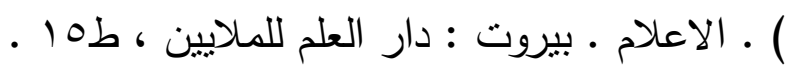

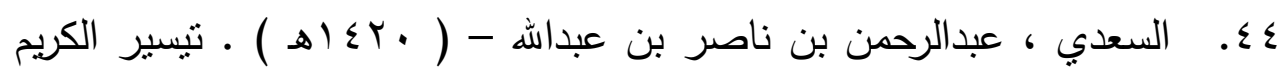
الرحمن في تفسير كلام المنان تحقيق : عبدالرحمن بن معلا اللويحقي ،

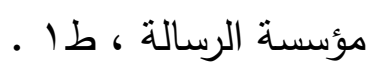




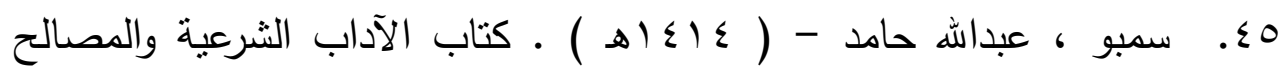
المرعية لابن مفلح المقدي الحنبلي المتوفي سنة ( rاVهـ ) دراسة وتحقيق الجزء الأول من الكتاب الى نهاية فصل ( قد سبق الكلام في بر الوالدين ) . رسالة دكتوراه غير منشورة ، كلية الثربعة ، جامعة أم القرى .

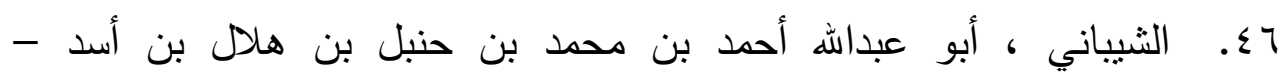

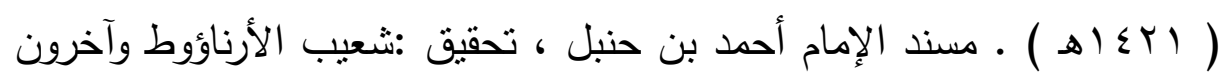
، ط1

ـ V

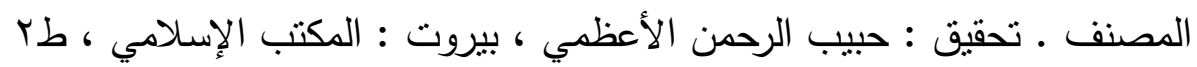

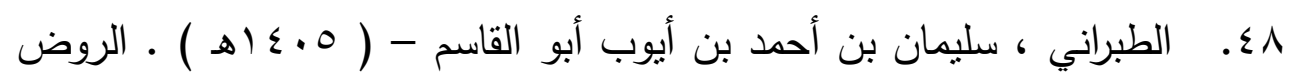

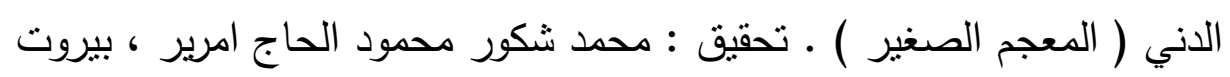

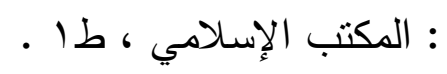

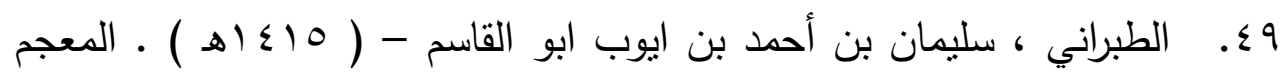
الأوسط ـ تحقيق : طارق بن عوض الله وعبدالمحسن الحسيني ، القاهرة : دار اله اله

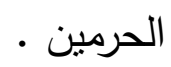
•. الطبراني ، للحافظ ابي القاسم سليمان بن احمد - ( د . ت ) . المعجم

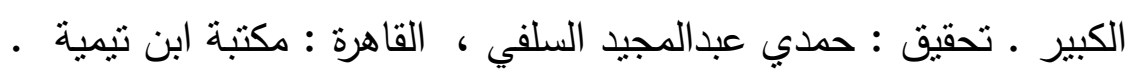
10. الطبري ، أبو جعفر محمد بن جرير بن يزيد بن كثثر بن غالب الآملي -

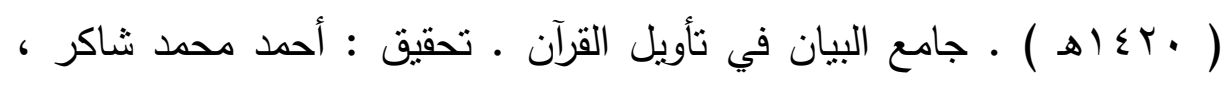

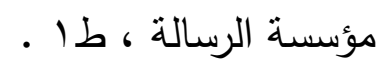
ror. العامر ، زياد حمد - ( بr؟ اهـ ). جهود ابن مفلح الحنبلي في تقرير

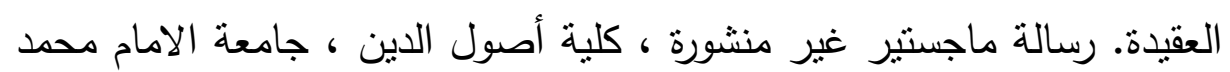

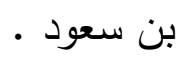




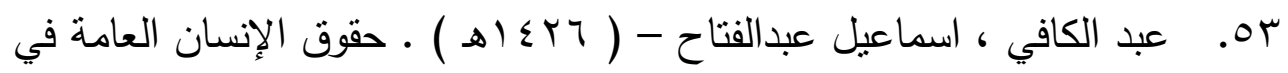

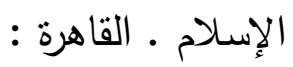

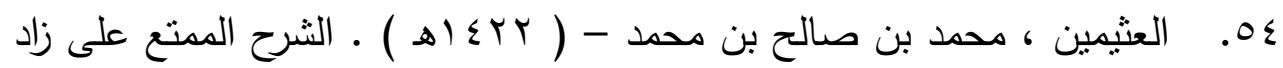
المستقنع • تحقيق : عمر سليمان الحفيان ، الرياض : دار ابن الجوزي ، طا

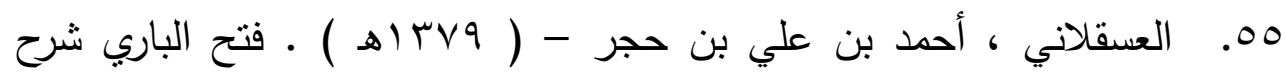
صحيح البخاري • بيروت : دار المعرفة . 07. العسقلاني ، أحمد بن علي بن محمد بن أحمد بن حجر - ( ب ب الهـ ) . الدرر الكامنة في أعيان المائة الثامنة. الهند ( حيد أباد ) : مجلس دائرة

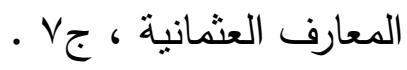

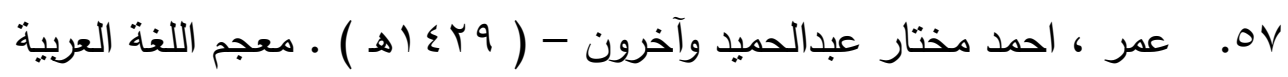

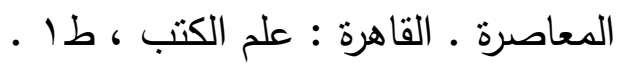

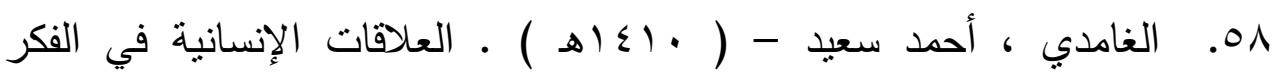
الإداري الإسلامي ومضامينها وتطبيقاتها التربوية ـ رسالة ماجستير غير منشورة • مكة المكرمة : كلية التربية / جامعة أم القرى . ه. فودة ، حلمي وآخرون - ( م •ـ اهـ ) ـ المرشد في كتابة الأبحاث التربوية . جدة : دار الشروق ، طه هـ

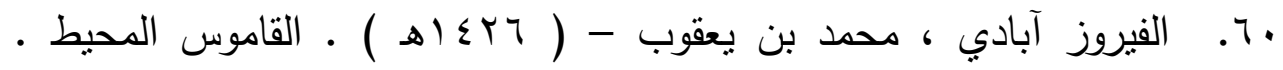

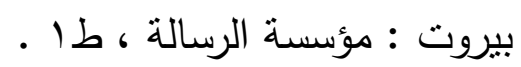

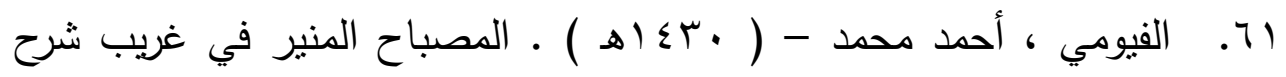
الكبير • تحقيق : عبدالعظيم الثناوي ، القاهرة : دار المعارف ، طب

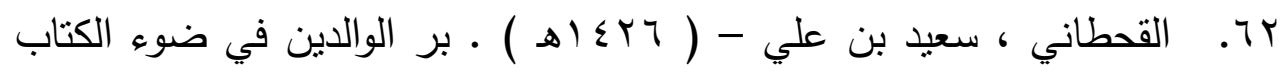
والسنة ـ الرياض : مؤسسة الجريسي للتوزيع والإعلان . 
با7. القحطاني ، سعيد بن علي - ( ابسا (هـ ) . الربا أضراره وأثناره في ضوء

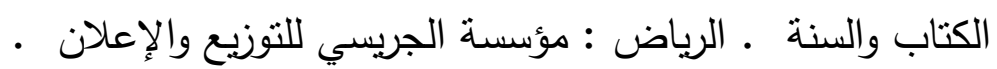

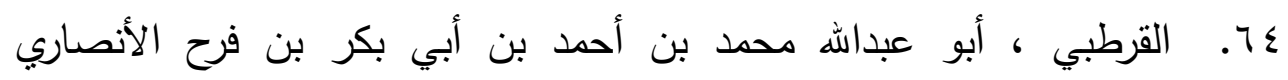
الخزرجي شمس الدين - ( ع ا اهـ ) ـ الجامع لأحكام القرآن (تفسير القرطبي ) • تحقيق : احمد البردوني وإبراهيم أطفيش ، القاهرة : دار الكتب المصرية ، طب لإن 7.

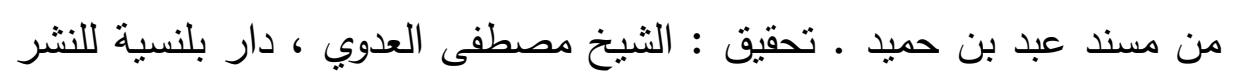

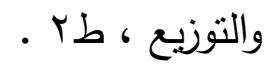
77. الكفوي ، أبو البقاء الحنفي أيوب بن موسى الحسيني القريمي - ( د ـ ت ) . الكليات معجم في المصطلحات والفروق اللغوية ـ تحقيق : عدنان درويش و محمد المصري ، بيروت : مؤسسة الرسالة .

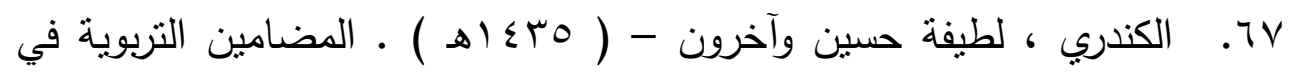
فكر الإمام الثافعي • المجلة التربوية ، القاهرة : جامعة سوهاج ، العدد (r^) . 1 7. الماوردي ، ابو الحسن علي بن محمد بن محمد بن حبيب البصري البغدادي

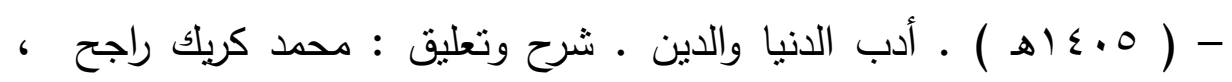
بيروت : دار اقرأ ، طء جديدة ومنقحة .

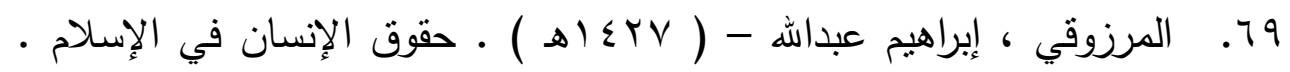
ورقة عمل مقدمة للندوة العالمية للتعايش السلمي في الإسلام بكولمبو - جمهورية

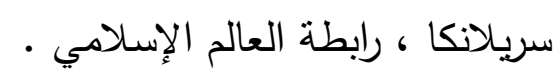

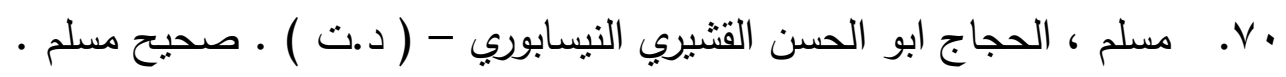
بيروت : دار احياء التراث العربي .

ا V. مصطفى ، إبراهيم وآخرون - ( د . ت ) . المعجم الوسيط ـ القاهرة :

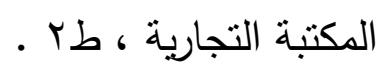




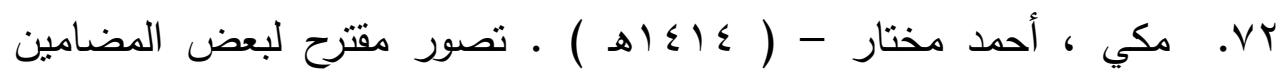

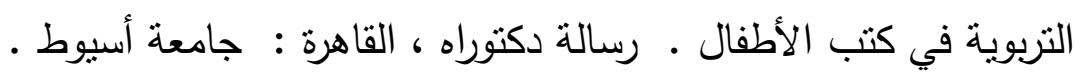
rr. المناوي ، زين الدين محمد المدعو لعبدالرؤوف بن ناج العارفين علي بن زين العابدين الحدادي - ( به با اهـ ) ـ فيض القدير شرح الجامع الصغير ـ تعليق : ماجد الحموي ، مصر : المكتبة التجارية الكبرى ، طا ل . ل ع V. المناوي ، زين الدين محمد المدعو لعبدالرؤوف بن ناج العارفين علي بن زين العابدين الحدادي - ( · (ـ اهـ ) .التوقيف على مهمات التعاريف ـ القاهرة :

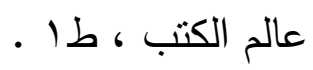
هV. النماصي ، بدر بن جزاع بن نايف - ( سr؟ اهـ ) . آداب المعلم والمتعلم عند الإمام ابن مفلح من خلال كتابه الآداب الثرعية والمنح المرعية وتطبيقاتها

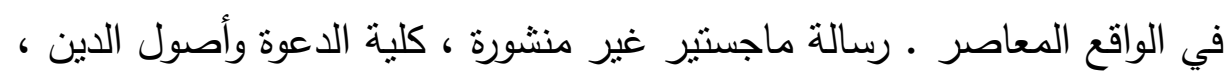

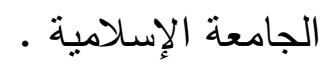

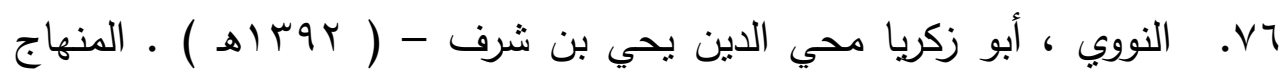

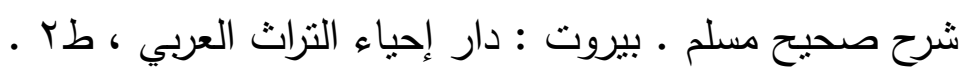

